$$
\text { UNIVERSIDADE DE SÃO PAULO }
$$

FACULDADE DE FILOSOFIA, LETRAS E CIÊNCIAS HUMANAS

DEPARTAMENTO DE LETRAS CLÁSSICAS E VERNÁCULAS

PROGRAMA DE PÓS-GRADUAÇÃO EM LETRAS CLÁSSICAS

\title{
SENDO HOMEM: A GUERRA NO ROMANCE GREGO
}

\section{LUCIA SANO}

Tese apresentada ao Departamento de Letras Clássicas e Vernáculas, Programa de Pós-Graduação em Letras Clássicas, da Faculdade de Filosofia, Letras e Ciências Humanas da Universidade de São Paulo para obtenção do título de doutor.

Orientadora: Prof. Dra. Adriane da Silva Duarte

São Paulo, dezembro de 2013

\section{VERSÃO CORRIGIDA}


Aos meu pais

e ao meu irmão Fábio 


\title{
RESUMO
}

Episódios bélicos são convencionais na estrutura do romance grego. Por se tratar de um tema fundamental da cultura grega, a guerra permite, por um lado, que seja explorada a relação entre esse novo gênero e a tradição literária (em especial a épica e a historiografia), e, por outro lado, que se estabeleçam diversos ideais de masculinidade. Assim, nesta tese investigam-se os episódios bélicos dos romances de Cáriton de Afrodísias, de Longo e de Heliodoro tendo em vista a representação de aspectos como andreia ("coragem", "masculinidade"), autocontrole (sophrosyne) e violência dos personagens masculinos. Sugere-se que é possível observar nessas narrativas uma valorização do controle da raiva e da violência em detrimento da habilidade marcial e do uso da força como manifestação de andreia, o que revela uma concepção de heroísmo mais afim com o contexto cultural em que eles foram produzidos.

Palavras-chave: literatura grega, romance grego, guerra, masculinidade

\begin{abstract}
War episodes are conventional in the structure of the Greek novel. As a fundamental aspect of the Greek culture, the war theme not only allows the authors to explore intertextual relations between this new genre and the literary tradition (especially epic poetry and historiography), but it also provides means to establish ideals of masculinity. The purpose of this thesis is therefore to investigate the war episodes in the novels of Chariton of Aphrodisias, Longus and Heliodoros, considering the representation of aspects such as andreia ("bravery", "masculinity"), self-control (sophrosyne) and violence of the male characters. I suggest that it is possible to argue that these narratives favor the control of anger and violence over martial prowess and the use of force as a manifestation of andreia, thus revealing a conception of heroism more akin to the cultural context in which they were produced.
\end{abstract}

Key-words: Greek literature, Greek novel, war, masculinity 


\section{AGRADECIMENTOS}

À Fapesp e à Capes, por financiarem parte desta pesquisa;

À Professora Doutora Adriane Duarte, pela generosidade com que sempre me orientou desde a graduação, incentivando o desenvolvimento de todas as ideias que eu lhe apresentei e dando-me a liberdade inestimável de traçar um caminho próprio;

Aos Professores Doutores Christian Werner e Fernando Rodrigues Jr., que me fizeram valiosas sugestões no exame de qualificação; aos demais professores da área de Letras Clássicas da Universidade de São Paulo, com quem muito tenho aprendido;

Aos funcionários da biblioteca central da FFLCH e da secretaria de pós-graduação do DLCV;

Aos professores e colegas do Seminário Internacional de Delfos de 2011;

Aos meus alunos e colegas da Universidade Federal de São Paulo, onde os desafios e estímulos possibilitam que eu me torne uma pesquisadora melhor; em especial a Bianca Morganti e a Josiane Martinez, pela cooperação e pelo bom humor que tornam o trabalho mais fácil;

Aos amigos Álisson Araújo, Erika Werner, Flávia Lins, Flávia Vasconcellos, Frederico Sabino, Graciela Foglia, Izabella Lombardi, Lana Lim, Leonardo Vieira, Milena Faria, Nara Sano, Nelson Vasel, Patrícia Dávalos, Rafael Brunhara, Raquel Madanelo, Roberto Souto, Uiran Gebara e Valéria Pereira da Silva, por coisas demais para enumerar aqui, mas todas elas muito valiosas; especialmente a Camila Zanon, pela leitura atenciosa e generosa da tese e pelas conversas que adentram a madrugada;

Finalmente, aos queridos Christian Werner (mais uma vez) e Robert de Bröse, que no contato quase diário fizeram mais feliz o cotidiano desta pesquisa. 


\section{Índice}

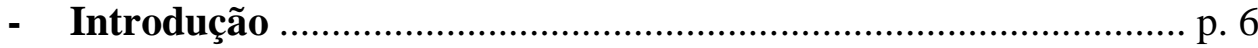

- Primeiro Capítulo:

O Romance Grego..................................................................... 21

\section{I.1 Contextos}

I.1.1 A (falta de) teorização na Antiguidade.................................... p. 25

I.1.2 O problema das origens......................................................... p. 31

I.1.3 Os leitores do romance....................................................... p. 40

\section{I.2 A prática literária}

I.2.1 Apropriações da tradição ....................................................... p. 45

I.2.2 Guerra e Violência.............................................................. p. 58

- Segundo Capítulo:

Quéreas e Calírroe: Um Marido Ideal........................................... p. 66

II.1 Resumo do enredo................................................................. p. 71

II.2 Relações entre Historiografia e Eros:

como ser homem (público)....................................................... p. 73

II.3 A guerra por Calírroe ................................................................... p. 81

II.4 A guerra de Quéreas.................................................................. p. 89

II.5 A violência de Quéreas................................................................ p. 95

II.6 A história com final feliz........................................................ p. 109

- Terceiro Capítulo:

Dáfnis e Cloé: A Lição de Pã Stratiótes ......................................... p. 115

III.1 Resumo do enredo................................................................... p. 118

III.2 O proêmio de Dáfnis e Cloé........................................................ p. 121

III.3 O prazer da guerra e da violência.............................................. p. 131 
- Quarto Capítulo:

As Etiópicas: Um Novo Aquiles ................................................... p. 156

IV.1 Resumo do enredo.............................................................. p. 157

IV.2 As Etiópicas: uma odisseia filosófica?........................................ p. 161

IV.3 Teágenes e Caricleia entre bandidos e piratas:

a violência de Tíamis................................................................. p. 167

IV.4 Teágenes entre os etíopes: a liderança de Hidaspes....................... p. 185

- Conclusão:

\section{A Guerra no Romance Grego:}

Controlando a Violência?

p. 199

- Referências Bibliográficas

p. 214 


\title{
INTRODUÇÃO
}

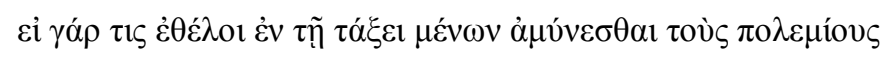

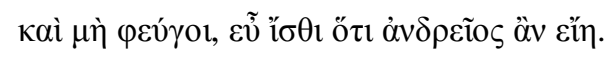

Se um homem pretender manter-se em seu posto para rechaçar os inimigos, e não fugir, fique sabendo que ele

possui andreia.

Platão, Laques, 190e5

A menção ao "romance grego" provocava, não muito tempo atrás, certamente um estranhamento em círculos menos familiarizados com a literatura grega produzida no período imperial. Nas duas últimas décadas, porém, se testemunhou uma forte ascensão do estudo daquilo que já se chamou de o último legado dos gregos e também de gênero literário mais bem-sucedido da história: a ficção narrativa em prosa. Os nomes de Cáriton de Afrodísias, de Xenofonte de Éfeso, de Longo, de Aquiles Tácio e de Heliodoro de Émesa começam a soar cada vez menos obscuros entre os estudiosos de literatura. Mesmo que hoje talvez não evoquem imediatamente histórias de amor com final feliz, nem por isso se estranhará o anacronismo caso se esclareça que é de escritores de romance que se fala.

Entre os diversos experimentos literários de ficção em prosa observados no período conhecido como Segunda Sofística, tradicionalmente se considerou que os textos que formam o objeto central de estudo desta tese possuem tal quantidade de características comuns que permitem identificar uma prática literária específica: são os chamados romances de amor. ${ }^{1}$ A história da recepção crítica desses textos é complexa e oscilou da presença totalmente justificada no cânone dos textos clássicos ao quase ostracismo entre o século XIX e a primeira metade do XX. Criticadas por leitores educados, segundo alguns poucos testemunhos contemporâneos que parecem fazer referência à forma, sobretudo pela falta de "seriedade" do conteúdo narrativo, as histórias de amor foram vistas de modo desfavorável por questões morais na

\footnotetext{
${ }^{1}$ Os críticos de língua inglesa preferem a expressão "ideal novel", identificando os mesmos textos não pelo tema erótico, mas pelo tratamento a ele dado.
} 
Antiguidade e no Período Bizantino. No Renascimento, porém, houve uma apreciação bastante positiva de alguns romancistas gregos, sobretudo de Heliodoro, elevado à posição de grande autor épico, ao lado de Homero e de Virgílio. ${ }^{2}$ A partir do final do século XIX, porém, quando Erwin Rohde publicou o livro fundador dos estudos modernos do romance antigo, Der Griechische Roman und Seine Vorläufer (1876), a grande (e única) questão que parecia instigar análises críticas era a do seu surgimento, o que se manteve por algumas décadas. Pretendia-se fazer uma análise "genealógica" que apontasse de quais características de quais gêneros o romance teria se apropriado, a fim de se constituir como decadência de uma tradição literária gloriosa.

Essa concepção do romance como forma decadentista, produzida para a leitura de pessoas pouco cultas, não resistiu à segunda metade do século $\mathrm{XX}$, com uma mudança que começou a se desenhar com as importantes publicações de Perry (1967) e de Reardon (1971). E ainda que muito se tenha esclarecido nos últimos cinquenta anos sobre a origem do gênero, a questão foi sendo gradualmente deixada de lado, um pouco pela percepção de que é bastante provável que ela permaneça sem resposta, ${ }^{3}$ mas também porque se passou a ver os textos como objetos de estudo por si só interessantes, principalmente a partir do momento em que teorias modernas da narrativa começaram a ser empregadas aos textos antigos, ${ }^{4}$ e quando se percebeu a importância do romance na análise de uma instigante questão cultural: a constituição da identidade grega em uma grande extensão geográfica sob domínio romano.

Em linhas bastante gerais, nos romances de amor um casal muito jovem se apaixona no início da narrativa, mas diversos obstáculos impedem ou interrompem sua união. Separados, eles enfrentam em diversos locais do Mediterrâneo muitos perigos e aventuras, como rapto por piratas, naufrágios, pretendentes indesejados, guerra, escravidão, prisão e tortura, mas os personagens sempre conseguem se manter castos ou fiéis um ao outro (ao menos no caso das heroínas) até o momento em que o reencontro garante um final feliz. Em parte do corpus, a história é ambientada alguns séculos antes do período em que os textos foram compostos, em geral no período clássico da Antiguidade grega. A uniformidade reconhecível nos enredos distingue-os, assim, de

\footnotetext{
${ }^{2}$ Cf. Bertoni e Fusillo (1993), Pinheiro (1996) e Sandy (1996).

${ }^{3}$ Cf. Bowie e Harrison (1993).

${ }^{4} \mathrm{O}$ estudo narratológico de Apuleio feito por Winkler é um marco importante (1985).
} 
outras formas fictícias em prosa que se desenvolveram no mesmo período e parece ter se tornado familiar para os leitores da Antiguidade. ${ }^{5}$

Há, portanto, uma tópica bem delimitada do romance ${ }^{6}$ e, como observa Hägg (1983, p.3), trata-se de textos que têm basicamente como constituintes principais o amor, a viagem e a violência. Embora alguns estudiosos identifiquem como temas principais do romance o amor e a aventura, é notável que nos cinco textos não fragmentários que possuímos a parte da "aventura" está relacionada principalmente à violência, uma característica que lhe é distintiva e que em dois romances (no de Heliodoro e no de Xenofonte de Éfeso) chega a resultar no assassinato pela heroína de seus agressores, a fim de garantir a preservação de sua castidade. Além disso, o corpus de fragmentos de romances é bastante variado e, em todo o processo que acabou por decidir quais textos seriam preservados integralmente, parece que foram preteridos aqueles em que a violência se apresentava de forma mais grotesca, no que deve ter pesado o gosto dos leitores bizantinos. ${ }^{7}$

No período em que os romances conhecidos foram produzidos, ação de piratas já deixara de ser um problema, havendo uma possibilidade muito menor do que no período helenístico de que gregos livres fossem raptados e vendidos como escravos, como sói acontecer com os personagens do romance. ${ }^{8}$ Estudos recentes sugerem que alguns elementos recorrentes do gênero podem ter sua apropriação literária relacionada a tradições narrativas não helênicas, como a presença dos bandidos egípcios conhecidos

\footnotetext{
${ }^{5}$ A definição do gênero feita por Holzberg (1995, p.20) parece-nos apropriada: "by 'ancient novel' we mean an entirely fictitious story narrated in prose and ruled in its course by erotic motifs and a series of adventures which mostly take place during a journey and which can be differentiated into a number of specific, fixed patterns. The protagonists or protagonist live(s) in a realistically portrayed world which, even when set by the author in an age long since past, essentially reflects everyday life around the Mediterranean in late Hellenistic and Imperial societies; the actual characters, however, are given idealistic or comic-realistic features".

${ }^{6}$ Létoublon (1993) sobre lugares-comuns do romance e Billaut (1991, p.191-221).

${ }^{7}$ Sandy (1996, p.738): "Photius' moral code seems to have precluded or reduce his summaries of some ancient Greek novels that would otherwise have been available to serve as models for Renaissance novelists. It is striking that his notice of Achilles Tatius' novel is much shorter (only fifteen lines in Henry's edition) than his summaries of the novels of Heliodorus (155 lines) whose propriety he repeatedly praises".

${ }^{8}$ Cf. Souza (2002, p.214-218).
} 
como Boukoloi. ${ }^{9}$ Pode-se discutir quão apropriado é avaliar um motivo como exclusivamente literário e não representativo da sociedade contemporânea, mas a questão de como as ansiedades reais dos leitores estão representadas na violência convencional do romance é uma questão complexa e até o presente momento não se realizou nenhum estudo que a analisasse de forma abrangente, não apenas no que diz respeito aos seus antecedentes literários, mas justificando sua presença a partir do seu apelo às audiências do período imperial, momento em que se produziram os exemplares conhecidos do gênero. ${ }^{10}$ Ainda que desde o estudo de Perry (1967) se tenha em geral assumido que as condições históricas e psicológicas do indivíduo da forma como estão refletidas no romance apontam para o período helenístico como momento de constituição do gênero, a hipótese feita por Bowie (1996 e 2002), e hoje bastante aceita, de que a Ásia Menor é, na verdade, o provável local de origem do romance, implica repensar o contexto em que o gênero teria florescido. Nessa região, as maiores cidades não chegariam perto de ter o tamanho dos centros urbanos do Egito, de modo que Bowie pondera que as condições psicológicas do indivíduo aí poderiam ser muito diferentes daquelas usualmente imaginadas para a sociedade egípcia do período helenístico.

O caráter muitas vezes violento das aventuras coloca herói e heroína romanescos na posição de vítimas. Da análise da representação do casal protagonista resultou uma visão comum de um herói passivo e fraco, frequentemente ofuscado por uma heroína mais decidida e perspicaz. Contudo, a partir das ideias expostas por Foucault no terceiro volume de sua História da Sexualidade (O Cuidado de Si), publicado em 1984, segundo as quais o romance grego celebra o amor heterossexual recíproco, a virgindade e o casamento, em um novo modelo de relação erótica em detrimento das relações homossexuais "estéreis", Konstan (1994) desenvolveu com mais detalhe a leitura de que simetria sexual entre o casal protagonista é distintiva desse gênero literário e justifica as atitudes do herói. ${ }^{11}$ No romance, ambos herói e heroína são jovens, belos, pertencentes à elite urbana e apaixonados um pelo o outro. O enredo está organizado em paralelos entre suas aventuras, o que serviria para estabelecer uma identidade na resposta dos dois aos perigos que enfrentam, não sendo, portanto, o gênero sexual um fator que resulta na

\footnotetext{
${ }^{9}$ Cf. Rutherford (2000).

${ }^{10}$ Porém, cf. Chew (2003) e Scippacercola (2010).

${ }^{11} \mathrm{O}$ crítico, porém, discorda fundamentalmente de Foucault ao considerar a simetria sexual como mero tema literário, não representativo da sociedade contemporânea.
} 
sua diferenciação. Assim, o herói não se colocaria no papel de salvador da donzela porque isso significaria desestabilizar a construção dessa simetria sexual, ao passo que a exposição de seu sofrimento, que com frequência leva à consideração do suicídio, serviria para intensificar a representação do amor entre o casal, que demonstra ser fiel aos seus sentimentos mesmo nas circunstâncias mais adversas (idem, p.8):

\begin{abstract}
Essa convenção expôs o amante masculino em todos os romances gregos à acusação de passividade, beirando à pusilanimidade, pelos críticos cujas expectativas estão evidentemente condicionadas pelo romance romântico moderno ou outros gêneros cavalheirescos. Nos romances gregos, suspiros, lágrimas e tentativas de suicídio são características do homem e da mulher em situações de sofrimento.
\end{abstract}

Konstan toca aí em um ponto essencial: os heróis não se comportam de acordo com o papel sexual que a audiência contemporânea imagina para um protagonista masculino, de quem se tem uma expectativa de coragem e liderança criada não apenas pelo paralelo com sua experiência de leitura dos romances modernos, mas também na comparação com os heróis épicos. Mesmo que Odisseu, sobretudo após a leitura estoica de seu personagem, seja para os romancistas um claro modelo de perseverança diante dos diversos sofrimentos que tem de enfrentar para retornar a sua casa e reencontrar sua esposa, o herói romanesco não herda dele a iniciativa para superar os obstáculos e os problemas resolvem-se quase sempre por forças que estão além de sua ação.

Depois da publicação de diversos estudos acerca da questão da sexualidade no romance grego, que retomaram ou contestaram a análise de Foucault, ${ }^{12}$ a representação das personagens femininas também passou a ser um tópico de bastante interesse. ${ }^{13}$ Nos últimos quinze anos, porém, foram várias as publicações sobre a questão da masculinidade na Antiguidade, ${ }^{14}$ um tema que passou a ser objeto de investigação das

\footnotetext{
${ }^{12}$ Winkler (1990), Konstan (1994), Goldhill (1995), Morales (2008), Pinheiro, Skinner e Zeitlin (2012).

${ }^{13}$ Wiersma (1990), Egger (1994a, 1994b, 1999), Johne (1996), Haynes (2003). Contribuições importantes também foram dadas por Morales (2005a e 2005b) e Lalanne (2006).

${ }^{14}$ Gleason (1995), Foxhall e Salmon (1998a, 1998b), Hobbs (2000), Gunderson (2000), Rosen e Sluiter (2003), Roisman (2005), Mcdonell (2006), Nortwick (2008).
} 
ciências sociais a partir da segunda onda do feminismo, nos anos $1960 .{ }^{15}$ Porém, a bibliografia sobre o assunto especificamente no romance é bastante restrita e apenas muito recentemente um trabalho de fôlego foi publicado sobre a masculinidade dos heróis romanescos, Playing the Man, de Meriel Jones (2012), que analisa três temas centrais (paideia, andreia e ideologia sexual) na sua representação, a partir da abordagem da "performance" do gênero sexual, que leva em consideração a consciência desses personagens a respeito de um ideal masculino a que eles aspiram e que eles percebem depender da construção ou da manutenção de uma determinada imagem diante dos outros. Assim, eles interpretam seus papéis de acordo com o que julgam apropriado para uma apreciação positiva de sua "plateia". Ainda que se dedique ao estudo das personagens femininas, Haynes (2003) também analisou os heróis como contraponto necessário ao estudo da feminilidade. Outro trabalho importante é o de Lalanne (2006), que percebe o romance como um gênero literário em que ritos de passagem tem como fim constituir identidades de gênero sexual.

Anteriormente, Balot (1998) havia empregado a teoria ética de Foucault ao analisar em um artigo o efeito do amor na representação da masculinidade em Cáriton de Afrodísias. Hopwood no mesmo ano discutiu brevemente de que forma os bandidos são caracterizados no romance, a fim de se estabelecer paradigmas masculinos negativos. Partindo da mesma consideração de que os bandidos e piratas oferecem um contraponto ao herói, Watanabe (2003) fez uma análise especificamente do personagem Hipothoo, de As Efesíacas, de Xenofonte de Éfeso, chegando, porém, a outra conclusão. A caracterização do pirata é tão ambígua no texto a ponto de ter sido frequentemente justificada pela falta de habilidade literária do autor. De fato, a um leitor moderno é estranho que um mesmo personagem seja tanto o melhor amigo do herói quanto um bandido capaz de jogar, sem demonstrar nenhum remorso, a heroína em um buraco com dois cães bravos - e esfomeados - para vingar a morte de um companheiro (IV.6), que ela havia matado unicamente para não ser violentada. Watanabe busca explicar a caracterização de Hipothoo de outra forma, justificando que ele possibilita uma representação positiva de uma masculinidade mais ativa, aplicando o conceito de "masculinidade hegemônica" de Connell, ${ }^{16}$ por oposição ao modelo dos heróis dos

\footnotetext{
${ }^{15}$ Para uma introdução às diversas perspectivas teóricas sobre masculinidade, Haywood e Mac an Ghaill (2003)

${ }^{16}$ O conceito é assim definido por Connell (2005, p.77, primeira edição de 1995): "The configuration of gender practices which embodies the currently accepted answer to the problem of the legitimacy of
} 
romances gregos, cuja passividade é quase uma constante. Hipothoo seria, assim, um exemplo tão poderoso de masculinidade que poderia comandar bandidos, em vez de se tornar vítima deles, e sua iniciativa seria necessária em alguns momentos para suplementar a falta de ação do herói.

Se com frequência os protagonistas do romance caem nas mãos de bandidos capazes de exibir uma força que o herói não possui, por outro lado, a exibição de uma masculinidade aristocrática era tradicionalmente relacionada a conflitos bélicos. Quando esta tese começou a tomar forma, a intenção inicial era a de estudar os episódios bélicos no romance de uma perspectiva intertextual, da qual resultasse uma análise sobre a apropriação da tradição literária e sua importância no processo de construção de identidade cultural helênica no período imperial, no que diz respeito a tema tão fundamental ao cânone grego, desde os heróis da Guerra de Troia representados na épica e na tragédia aos relatos historiográficos de sucessivos conflitos em que os gregos se envolveram a partir do período arcaico. Porém, um ponto essencial era primeiro estabelecer que funções esses episódios assumiam no projeto narrativo de cada um dos romancistas, até para ajudar a demonstrar que apesar de estruturado por elementos convencionais, o corpus que constitui o que conhecemos como romance grego é variado e instigante nas soluções que cada um dos autores encontra para desenvolver os tópoi que identificam o gênero. Ao se fazer isso, porém, percebeu-se que aquelas obras em que os episódios bélicos eram mais bem desenvolvidos - Quéreas e Calírroe, Dáfnis e Cloé e As Etiópicas - tinham em comum o estabelecimento de um paradigma de comportamento masculino, ainda que também se observassem nelas funções narratológicas distintas.

Críticos consideram que em Quéreas e Calírroe, o mais antigo dos romances conhecidos integralmente (e talvez, de fato, o primeiro exemplar do gênero, segundo uma tese recente), ${ }^{17}$ a importância fundamental da guerra é justificada como meio de dar a uma forma literária recém-criada a autoridade da tradição. ${ }^{18}$ Por se tratar de tema fundamental à cultura grega, a guerra permite, por um lado, que seja explorada ao máximo a relação entre esse novo gênero e a tradição literária, mas, por outro lado,

patriarchy, which guarantees (or is taken to guarantee) the dominant position of men and the subordination of women". Connell identifica diversos tipos de masculinidade em uma sociedade e analisa as relações de poder entre elas.

17 Tilg (2010).

${ }^{18}$ Fusillo (1989), especialmente p.56-67. 
também que se estabeleçam diversos aspectos de ideais masculinos que refletem aqueles de uma elite urbana do período imperial. Mesmo em um romance como o de Longo, cujo enredo envolve basicamente o desenvolvimento sexual de um casal de pastores, em que a guerra é um evento marginal que pouco altera o curso das vidas bucólicas dos personagens principais, é possível observar a construção de um ethos idealizado que diz respeito não ao campo, mas à esfera urbana compartilhada pelo autor, pelo narrador e pelos leitores - e apenas em uma fração, também por Dáfnis, o protagonista do romance, cujos pais biológicos vivem na cidade.

A guerra sempre foi vista como a situação por excelência para demonstração de "masculinidade" e de "coragem", ainda que ela seja esperada também em outros contextos. Isso fica claro no diálogo platônico Laques, centrado na definição de andreia, e no qual o personagem homônimo expõe a visão do ateniense comum sobre o assunto. ${ }^{19}$ Quando solicitado a oferecer sua definição, Laques responde que é permanecer no posto em campo de batalha, sem fugir dos inimigos (109e). A refutação de Sócrates a sua resposta demonstra que essa definição é muito estreita e que a andreia é algo mais abstrato, presente em outras situações e que diz respeito a outras esferas além da guerra; por exemplo, a como uma pessoa se porta diante de perigos no mar, doenças, pobreza, na política e no controle não apenas de dores e medos, mas também dos desejos. Ainda que seja imediatamente refutada, a resposta espontânea de Laques aponta para uma visão corrente do que significa ser andreios. Em outra passagem (184c), andreia e areté parecem ser usadas por ele casualmente de forma intercambiável, o que nos faz perguntar se "ser superior em andreia implica que alguém é necessariamente superior em excelência de uma forma geral" (Hobbs, 2000, p.83). Além disso, os personagens que iniciam o diálogo tomam como dado que se trata de algo que pode ser ensinado e que deve ser considerado o objetivo da educação dos meninos, ainda que as intervenções de Sócrates exponham a necessidade de primeiramente se definir o que é andreia para então se investigar se ela pode ou não ser ensinada. Embora o diálogo termine em aporia, a perspectiva inicial dos personagens é vista em outros autores do período clássico: "de fato, a coragem masculina foi concebida não tanto como um traço inerente à personalidade, mas como um ethos uma série de ideais e código de conduta - que era desenvolvido por meio da educação $e$ da socialização", afirma Roismann em trabalho que investiga o conceito de

\footnotetext{
${ }^{19}$ Sobre Laques, cf. Hobbs (2000, p.76-111).
} 
masculinidade nos oradores áticos $\left(2005\right.$, p.110). ${ }^{20}$ Uma concepção semelhante pode ser observada nos romances, i.e. trata-se de algo a ser adquirido pelo aprendizado, ou melhor, pela paideia, esse processo do qual resultam homens (e mulheres) capazes de exibir valores apropriados às expectativas da elite cultural grega do período imperial. ${ }^{21}$

A guerra seria, então, o momento em que o herói romanesco aprende a demonstrar sua coragem, atendendo a expectativas sociais amplas quanto a sua masculinidade, algo que serve de contraponto à sua caracterização inicial como herói passivo? Nem sempre. Esse parece ser exclusivamente o caso de Quéreas, no romance de Cáriton de Afrodísias, mas o fato não é de se estranhar, uma vez que parece subjazer nos romances uma concepção de andreia própria desse gênero literário. A palavra andreia se origina de anér, "varão", e é mais frequentemente traduzida como "coragem" do que como "masculinidade"; 22 entretanto, essa tradução mais corrente cria um problema que diz respeito não à etimologia, mas ao fato de que o termo na Antiguidade é marcado pelo gênero sexual, i.e. o seu desenvolvimento semântico nunca chegou ao ponto em que a palavra passou a ser utilizada também com relação às mulheres. ${ }^{23}$

Por se tratar de uma noção abstrata do comportamento masculino, o termo andreia foi bastante manipulado desde o período clássico. Na introdução do volume que organizaram sobre o tema, Rosen e Sluiter (2003) analisam alguns usos do termo em Aristófanes para demonstrar de modo exemplar como ele depende mais de uma

${ }^{20}$ Roisman (2005, p.110, nota 16) cita como exemplos Aristóteles, Ética a Nicômaco $3.81116^{\mathrm{a}} 17$, Xenofonte, Simpósio 2.11-12, Ciropédia 12.7, Tucídides 1.84.3.

21 "La paideia renvoie à deux notions distinctes: comme point de départ, elle est l'éducation donnée à l'enfant ou à l'adolescent; comme résultat, elle est ce qui constitue la culture de l'homme accompli" (Lalanne, 2006, p.183).

22 Trata-se de um termo pós-homérico cuja primeira ocorrência registrada está em Os Sete contra Tebas, produzida em 467 a.C. (v.52) ou em Heródoto (VI.99), a depender de qual datação se considere para o historiador. Bassi (2003) argumenta que em Homero a masculinidade é modelada por feitos tangíveis, físicos e marciais do anér heroico e que o desenvolvimento da noção abstrata de masculinidade, distinta de um atributo físico ou biológico, ocorreria apenas na autorrepresentação política ateniense (idem, p.33): "a exortação 'sejam homens' é proferida na preparação para o combate armado em que ser homem é algo demonstrado por ação física, ao se permanecer no posto e não recuar (i.e. Ilíada, 15.655-6)".

${ }^{23}$ Isso não significa que não haja registros da palavra com referência a mulheres, mas se trata em geral de um contexto anômalo ou o termo é empregado com concepção bastante distinta da tradicional. A ocorrência do termo em Heródoto, aliás, possivelmente a primeira, diz respeito ao desempenho de Artemísia na batalha de Salamina. Heliodoro afirma em algumas passagens que personagens femininas possuem andreia; cf. Jones (2012, p.106-117). Em Plutarco, cf. McInerney (2003). 
definição persuasiva do que denota uma essência, estando à mercê de contestações e apropriações, i.e., trata-se de algo construído discursivamente. Bassi (2003, p.28) observa que o interesse em dar definição semântica ao termo aponta para o reconhecimento de que o sentido desse conceito era objeto de disputa no século $\mathrm{V}$ a.C., e Roisman (2003) demonstra que, entre os oradores, ele era algo tão maleável que podia ser aplicado tanto em defesa da guerra quanto ao ato corajoso que representaria uma abstenção dela.

No período conhecido como Segunda Sofística, momento de auge da produção dos romances, circulavam discursos diferentes sobre o que significava ser andreios. Jones (2012, p.92-173) demonstrou que a andreia do herói do romance não identifica apenas uma "coragem masculina", mas está sujeita a uma transferência para a esfera erótica, de modo que também indica resistência diante das adversidades e proteção da castidade, ao passo que Lalanne (2006, p.204) argumentou que sua concepção é relacionada igualmente à potência sexual. Nesse contexto intelectual, porém, a "nova masculinidade" do herói romanesco é apenas uma a se contrapor a padrões mais tradicionais. Em suas investigações sobre os sofistas do século II d.C,, por exemplo, tanto Gleason (1995) quanto Connolly (2003) notam a aproximação desses intelectuais a uma imagem efeminada, mas mesmo assim a primeira analisa a autorrepresentação de sofistas como paradigmas de masculinidade e Connolly discute como eles afirmam ser capazes não só de ensinar técnicas discursivas, mas também de engendrar andreia nos seus alunos.

Mas como fica esse herói "passivo" do romance grego, cuja atitude tantas vezes em nada se diferencia da que demonstram as heroínas, se as guerras irrompem na narrativa como uma oportunidade única de demonstração de astúcia e de autocontrole, mas principalmente de coragem e de força, duas características em que com frequência ele é visto como deficiente? Como oposição à leitura de Konstan (1994), que sugeriu que as aventuras do romance têm como função pôr à prova e comprovar o amor do jovem casal de protagonistas, outra possibilidade de análise é entender a violência presente no romance como parte de uma aprendizagem, pelos quais os amantes devem passar a fim de se tornarem adultos em sentido pleno, aptos a assumir os papéis sociais esperados de uma mulher e de um homem da elite grega. Essa leitura foi sugerida de 
modo pontual diversas vezes ao longo da história da crítica do romance de amor, ${ }^{24}$ mas Lalanne (2006) foi quem desenvolveu uma tese abrangente do gênero como um todo, sugerindo ainda que se possa tratar de uma representação de ritos de iniciação como praticados nas cidades gregas do período imperial (op.cit., p.96-97), algo que implicaria uma resistência à autoridade romana. Nesse sentido, em um primeiro momento, os heróis do romance seriam caracterizados de modo negativo e o tema da guerra estaria presente por causa de uma percepção arcaizante dos personagens masculinos, na qual a demonstração de sua andreia ainda estaria relacionada a feitos militares.

Porém, ainda que os cinco romances completos que hoje conhecemos apresentem episódios bélicos, como já se afirmou, em apenas um deles o herói apaixonado, Quéreas, torna-se também herói de guerra. É certo que a habilidade militar é um traço desejável, mas a solução de Cáriton pode ter sido percebida, do modo como é hoje, como estranha e incongruente, de forma que os conflitos violentos oferecem, em Longo e em Heliodoro, a possibilidade de exibição da andreia não do herói, mas de outros personagens. A tradicional concepção da guerra como situação ideal para exibição de valores masculinos considerados paradigmáticos continua presente, ao menos nos três romances centrais para esta tese, só que no geral se observa que o herói do romance não participa dos conflitos. Assim, se esse herói representa um "novo tipo de masculinidade" (Watanabe, 2003, p.4), como ele interage com um modelo masculino mais tradicional? O herói em algum momento deliberadamente se afasta dele porque o amor condiciona suas atitudes? Se o bandido Tíamis, de As Etiópicas, é identificado com Heitor, pelo fato de entregar-se à guerra disposto a matar ou morrer, o que isso pode significar para a caracterização do herói Teágenes, que fugirá do mesmo conflito? E como entender esse tradicional paradigma de comportamento masculino relacionado à guerra da forma como é visto no romance em um contexto cultural no qual se está repensando a representação de masculinidade e dos valores a ela relacionados?

A investigação desta tese, portanto, considera a consciência dos romancistas de que seus heróis destoavam de um paradigma comum e é feita principalmente a partir de elementos da tradição literária que sejam apropriados, negados ou subvertidos nas situações de confrontos militares e na caracterização dos personagens neles envolvidos.

\footnotetext{
${ }^{24}$ Entre outros, por Perry (1930, sobre Cáriton), Hopwood (1998, ao contrastar as representações dos heróis e dos bandidos) e Whitmarsh (1999, sobre Heliodoro). Bakhtin entendeu que os heróis do romance antigo não sofreriam mudança ao longo da narrativa, o que os diferenciaria dos heróis do romance moderno. Cf. Branham (2002).
} 
O foco da dissertação não é discutir o uso do termo andreia e de seus cognatos, mas sim analisar de que modo os episódios bélicos integram o projeto narrativo dos romancistas no que diz respeito ao estabelecimento de um modelo de comportamento masculino, composto ainda por outros valores, como astúcia, autocontrole (sophrosyne) e generosidade (philanthropia). Embora o recorte escolhido para a investigação possa sofrer a crítica de não ser amplo o suficiente para que se tenha uma visão abrangente do tratamento dado pelos romancistas à questão da masculinidade, acredito que ele ofereça algumas vantagens.

A primeira, já anunciada, é a de considerar o projeto narrativo individual de cada um dos romancistas no desenvolvimento de um episódio convencional na estrutura do gênero, ao qual pouca atenção foi dada. ${ }^{25}$ A outra é o de selecionar uma situação em que se possa observar como as várias masculinidades representadas nos romances interagem em relações hierárquicas. Assim, por exemplo, no abrangente estudo de Jones (2012) sobre a masculinidade do herói grego - uma abordagem necessária e que veio a preencher de forma feliz uma enorme lacuna nos estudos sobre o romance - chega-se à conclusão de que a masculinidade do herói é construída principalmente por meio da alteridade, em que o "outro" é o homem efeminado ou ao menos o "not-fully-manly" (idem, p.273). Creio que se trata de uma conclusão quase inevitável caso se busque uma uniformidade nas representações dos personagens masculinos dos diferentes romances que conhecemos. Porém, ainda que Jones não se refira, nessa conclusão, somente à questão da sexualidade, que é parte privilegiada da caracterização dos heróis, a meu ver ela não dá a devida importância a outros tipos de oposição por meio das quais a masculinidade do herói é construída, como na relação com figuras de poder e de autoridade, tais como os bandidos ou as "figuras paternas", de que são exemplos Hidaspes e Hermócrates, que mais claramente desafiam a ideia de uma caracterização positiva do herói romanesco e evidenciam valores que devem ser adquiridos no seu amadurecimento ou, ainda, traços de personalidade a ser controlados. Daí também que nossa abordagem privilegie a construção poética desse herói por meio da apropriação da tradição literária, onde os romancistas vão buscar elementos para uma representação de gênero sexual com contornos mais bem reconhecíveis.

Embora a análise de Lalanne (2006) sobre os ritos de passagem nos pareça interessante, uma leitura como a dela, que busca abarcar o gênero do romance como um

\footnotetext{
${ }^{25}$ Sobre a guerra no romance em geral, Fusillo (1989, p.56-67), Scarcella (1992), Hilton (2005).
} 
todo uniforme, é problemática por desconsiderar que cada autor pode dar funções diferentes às convenções estabelecidas, uma vez que nos parece que Quéreas e Calírroe apresenta uma concepção da guerra e do herói que é retomada por outros romancistas, mas não reproduzida. Para a crítica francesa, porém, independentemente das funções narratológicas dos episódios bélicos, eles são sempre provas pelas quais os heróis devem passar em sua iniciação e aprendizagem sobre como ser andreios. Por outro lado, será discutida a hipótese de que no tratamento que Cáriton de Afrodísias, Longo e Heliodoro dão ao tema da guerra é possível discernir questões de construção da masculinidade que não dizem diretamente respeito ao valor marcial, mas ao controle das emoções, sobretudo daquelas que provocam impulsos violentos, o que não seria, portanto, uma concepção arcaizante do papel sexual masculino, mas revelaria preocupações da elite cultural do período.

Esta tese está organizada em quatro capítulos. O importante percurso da crítica do gênero romanesco no século $\mathrm{XX}$ e a configuração do romance de amor na Antiguidade são apresentados de modo breve no primeiro capítulo, que serve ao propósito de contextualizar de forma minimamente apropriada as discussões realizadas nos capítulos seguintes. São discutidas a (falta de) teorização do gênero na Antiguidade, sua recepção crítica moderna no que diz respeito às origens e ao público leitor do romance, sua concepção como amálgama de diversas práticas literárias canônicas e a presença da guerra e da violência nos enredos dos romances. Todas as traduções de citações de obras modernas e antigas nesta tese são minhas, salvo quando há referência ao tradutor.

Os demais capítulos são dedicados, em ordem cronológica, a cada um dos três romances que constituem o corpus desta tese. Uma vez que o romance grego ainda é pouco estudado nas universidades brasileiras, ${ }^{26}$ decidiu-se que seria interessante incluir um resumo do enredo e uma introdução inicial sobre as obras antes de se chegar à questão fundamental da guerra. O segundo capítulo é dedicado a Quéreas e Calírroe, de Cáriton de Afrodísias. Inicialmente se discute a relação do texto com a historiografia e as consequências dessa relação para a narrativa, buscando-se justificar a inserção do

\footnotetext{
${ }^{26}$ Destaca-se aqui o trabalho de Brandão (2005).
} 
tema da guerra no gênero romance, se considerarmos Cáriton um paradigma mais ou menos reconhecível para os demais romancistas. Em seguida, são analisados quatro aspectos do romance: a disputa entre os pretendentes de Calírroe como uma espécie de guerra, a aristeia de Quéreas na guerra contra os persas ao lado dos egípcios, no qual é

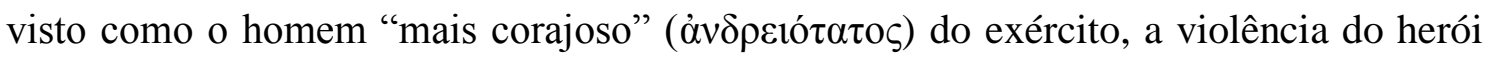
que resulta na morte (ou no assassinato) aparente da heroína e, por fim, o seu retorno triunfal à Sicília como digno da mão de Calírroe, o que equivale dizer digno de suceder Hermócrates como líder político e militar da cidade.

O terceiro capítulo é uma análise da guerra em Dáfnis e Cloé, de Longo. A presença do episódio bélico nesse romance sempre foi considerada uma convenção sem importância na narrativa e, recentemente, Trzaskoma (2005) argumentou que o tratamento que o autor dá ao tema pode ser considerado uma espécie de "declaração de independência" do romance da historiografia, tendo Longo optado por estratégias distintas daquelas de Cáriton ou do autor de Nino, conhecido apenas por fragmentos. Não há propriamente um desenvolvimento do tema que nos permita pensar na concepção de andreia nesse romance, o único, aliás, em que não há nenhuma ocorrência do termo ou de seus cognatos, mas a atividade militar é apresentada como parte essencial do que significa tornar-se homem e são destacadas ações nobres e ignóbeis em guerra. Nesse sentido, buscou-se demonstrar como, na verdade, a guerra é importante no projeto do autor, centrado na educação e no amadurecimento dos protagonistas, e de que forma ele se relaciona com os três mitos embutidos da narrativa nos quais, assim como no episódio bélico, o deus Pã é figura central.

As Etiópicas de Heliodoro são objeto de análise no último capítulo. Trata-se de um romance pontuado de conflitos violentos, pois não há apenas a grande batalha entre a armada etíope e os persas no livro IX pela disputa das minas de esmeralda, mas também lutas entre piratas e bandidos a que o autor se refere como guerras. Dessa forma, discute-se como o herói Teágenes é colocado em comparação com Tíamis, o líder do grupo de bandidos que é seu rival no amor de Caricleia. Também se analisa o comportamento de Hidaspes, rei etíope, e como a Teágenes são dadas outras oportunidades para demonstração de andreia que não as atividades militares.

Por estar centrada no uso da guerra como meio de estabelecer modelos positivos de masculinidade, durante a pesquisa foram preteridos os romancistas Xenofonte de Éfeso e Aquiles Tácio. O primeiro porque, embora recheie seu romance com diversas aventuras, muitas delas violentas, não desenvolve propriamente um episódio de guerra, 
embora dois conflitos armados ocorram e sejam discutidos brevemente no primeiro capítulo desta tese. ${ }^{27} \mathrm{O}$ caráter paródico do romance de Aquiles Tácio, por sua vez, não permite pensar o episódio bélico em Leucipe e Clitofonte como um momento em que se configura uma masculinidade como ideal, mas ele será discutido na conclusão como contraponto à valorização dada à guerra pelos outros romancistas. Nessa última seção da tese, também são expostas algumas hipóteses sobre a construção da masculinidade dos heróis do romance tanto no que diz respeito a convenções do gênero (possivelmente estabelecidas por Cáriton de Afrodísias) quanto à importância dada ao controle de impulsos violentos da parte dos personagens masculinos.

\footnotetext{
${ }^{27}$ Na seção "I.2.2 Guerra e Violência”.
} 


\section{O Romance Grego}

O período imperial, sobretudo o século II d.C., e o movimento conhecido como Segunda Sofística parecem ter visto florescer um grande entusiasmo com as possibilidades oferecidas pelo uso da prosa para veicular ficção, com a produção de textos que, embora partilhem características gerais (são ficção, são narrativas e são em prosa), têm características bastante diversas das do romance de amor. ${ }^{1}$ Alguns exemplos são o relato biográfico fantasioso de $O$ Romance de Alexandre, falsamente atribuído a Calístenes, historiador da corte de Alexandre, o Grande; A História de Apolônio, Rei de Tiro, conhecido apenas pela sua tradução latina e de autoria incerta; e as narrativas do cretense Dictis e do frígio Dares, que conhecemos igualmente por suas versões latinas e que são dois supostos testemunhos oculares da Guerra de Troia produzidos no século II d.C. ${ }^{2}$ Luciano de Samósata, por sua vez, elenca agora não só os títulos de satirista e retor, mas também de romancista, representante de uma vertente cômica do gênero, por conta do seu inventivo Histórias Verdadeiras e da autoria duvidosa, mas tradicionalmente a ele atribuída, de Lúcio, ou O Asno. Ainda que pareça desenvolver de alguma forma o elemento erótico, As Coisas Incríveis de Além-Tule, de Antônio Diógenes, não é uma história de amor, mas uma narrativa de orientação possivelmente satírica e de estrutura extremamente complexa, cheia de aventuras e parádoxa, conhecida apenas pelo resumo de Fócio (cod.166). Há também os relatos biográficos, como A Vida de Apolônio de Tiana, de Filóstrato, e os experimentos fictícios de menor extensão, frutos da Segunda Sofística, dos quais alguns discursos de Dion Crisóstomo que lidam com temas homéricos são bons exemplos, para não mencionar novamente parte da produção de Luciano. E aqui nos restringimos apenas à produção literária escrita em grego, sem considerar os textos cristãos.

\footnotetext{
${ }^{1}$ Sobre os chamados "fringe novels", o volume organizado por Schmeling (1996) apresenta contribuições importantes de diversos autores. A distinção entre o que se convencionou entender por "novel" e por “fringe novel" é questionada apropriadamente por Morales (2009).

${ }^{2}$ Sobre essas narrativas, cf. Merkl (2003).
} 
A homogeneidade de tema observada no romance de amor também não é vista nos fragmentos, reunidos em edição de Stephens e Winkler (1993). Se temos outros experimentos com ficção datados do período imperial, o pouco que os fragmentos revelam indica que a prática teria sido ainda mais variada. Consequentemente, a tradicional divisão entre a vertente grega do "romance idealizado" e a vertente latina do "romance cômico"3 não mais se sustentou após a publicação dos fragmentos conhecidos até o início dos anos de 1990 (idem, p.7):

\begin{abstract}
A Apuleio e Petrônio juntam-se agora vários outros fragmentos gregos - As Fenícias, Daulis, Iolao e Tinoufis. Eles compreendem o que parece ser um subgênero da ficção antiga, histórias que lidam com criminosos e grupos praticantes de cultos, frequentemente de maneira divertida ou ligeiramente escandalosa. Tanto em grego quanto em latim, o material básico desse tipo de entretenimento são magos, fugas de prisão, cultos sinistros, escândalo religioso e sacrilégio.
\end{abstract}

O clima cultural da época, em que autores fortemente conscientes de uma tradição helênica gloriosa trabalharam orientados pela mímesis literária, ${ }^{4}$ mas também por um forte impulso criativo, parece ter propiciado inovações formais, como o diálogo cômico de Luciano, e a reelaboração sofisticada de formas literárias já praticadas. Esse talvez tenha sido o caso do chamado romance de amor, cuja produção atualmente conhecida é comumente dividida pelos críticos em sofística e em pré ou não sofística. ${ }^{5}$ No caso do diálogo cômico, Luciano declara-se seu inventor e elabora uma verdadeira poética do gênero; mas em outros casos os textos não se enquadram em nenhuma das

\footnotetext{
${ }^{3}$ Como argumentada por Perry (1967).

${ }^{4}$ Cf. Bompaire (1958), que faz um importante estudo sobre a imitação no período, no qual classifica a criação em duas: retórica e literária. A segunda se diferenciaria da primeira por (p.158) "une application de la Mimésis plus subtile, un vrai raffinement de lettré. L'écrivain n'a plus devant l'héritage livresque un réflexe élémentaire de prise de possession - accompagné d'un minimum d'élaboration -, son esprit combine, transpose, parodie, prolonge des données littéraires sans cesser de leur être fidèle”.

${ }^{5}$ Preferimos a segunda possibilidade, romance não sofístico, pelo fato de a datação dos textos supérstites ser controversa, embora se saiba que Cáriton de Afrodísias e Xenofonte de Éfeso (os autores não sofísticos) são também os mais antigos. Não temos como saber, no entanto, se as duas práticas não coexistiram.
} 
práticas literárias teorizadas pelos antigos, restando ao estudioso moderno a necessidade de empregar termos anacrônicos para classificá-los.

Os textos escritos por Cáriton de Afrodísias (Quéreas e Calírroe), Xenofonte de Éfeso (As Efesíacas), Longo (Dáfnis e Cloé), Aquiles Tácio (Leucipe e Clitofonte) e Heliodoro (As Etiópicas) fazem parte desse grupo de textos para os quais nenhum autor antigo parece ter se preocupado em estabelecer uma teoria. Alguns termos possíveis, que discutiremos adiante, como diégema $(\delta i \eta ́ \gamma \eta \mu \alpha)$ e plásma $(\pi \lambda \alpha ́ \sigma \mu \alpha)$, eram também utilizados em referência a outros gêneros literários e não são, portanto, escolhas ideais. $\mathrm{Na}$ falta de um termo grego para nomear os textos aqui discutidos, utilizamos prontamente um termo latino atestado pela primeira vez na França do século XII, salvos que estamos de outra querela que os falantes de língua inglesa têm de enfrentar, que envolve a opção entre os termos romance e novel. Ambos se referem a narrativas de ficção, com a diferença de que o primeiro pressupõe uma nuança de idealização e sentimentalismo ausente no segundo, que diz respeito em princípio a obras de caráter realístico. Pode parecer uma complicação menor, mas Reardon acredita que o uso do termo "romance" teve implicações sérias na recepção dos textos antigos, resultando em desinteresse crítico. ${ }^{6}$

Ficamos, então, com "romance", ainda que se possa discutir quanto o romance "antigo" difere do "moderno" e se podemos, de fato, considerá-los um único gênero. Artificiais que são sempre os limites impostos teoricamente às práticas literárias, tratase de uma questão cuja resposta varia de acordo com a perspectiva crítica pressuposta quando da leitura dos textos. Alguns teóricos do romance deliberadamente apresentam definições que possam abranger de Cáriton de Afrodísias a Guimarães Rosa, ao passo que outros se detêm em questões temáticas e históricas que distinguem o fenômeno da ficção narrativa em prosa surgido no período pós-clássico daquele que ascende com a modernidade. ${ }^{7} \mathrm{O}$ fato é que aquela categoria tantas vezes mencionada, chamada "leitor

\footnotetext{
6 "'Romance' is princesses and dragons; it is not realistic, not serious. Trivial as it may now seem, I think that this nomenclature is a matter of substance, and helps explain the earlier neglect of the form in English-language scholarship" (Reardon, 2006, p.229). Fusillo (2006, p. 36) observa sobre o romance grego que "while the genre contained elements that were characteristic of romance, it was closer to the novel in concept, if for no other reason than the absence of fantastic elements and the presence of an everyday dimension".

${ }^{7}$ A restrição do uso do termo "novel" resulta em parte da definição de Ian Watt em seu The Rise of the Novel (1957), que quer que ela seja (p.8) "suficientemente estreita para excluir tipos de narrativas
} 
ingênuo", percebe o texto de autoria de Cáriton de Afrodísias como algo bastante próximo do que ele entende como romance, mas porque atualmente o termo identifica um gênero em prosa que pode tratar de temas inúmeros e utilizar as mais diversas técnicas narrativas. Essa concepção contemporânea, contudo, não afasta o romance moderno do antigo, uma vez que também este é uma forma aberta, capaz de tomar aspectos diversos ao incorporar e transformar em romanescos variados elementos dos demais gêneros literários - algo exemplarmente traduzido na expressão narrador gramatofágico, empregada por Brandão (2005). ${ }^{8}$ De fato, vários dos elementos considerados característicos do romance moderno foram observados também no antigo (a secularização, o isolamento do herói, o foco no privado e no sentimental e o sincretismo cultural). ${ }^{9}$ Caso se utilize, porém, os critérios abrangentes de Brandão para definição do gênero (os textos são em prosa, narrativos e fictícios), ${ }^{10}$ tem-se que considerar como romances um conjunto de textos da Antiguidade muito diferentes entre si que talvez os seus contemporâneos não percebessem como de alguma forma relacionados. $^{11}$

anteriores e ainda ampla o suficiente para ser aplicada a qualquer coisa normalmente colocada na categoria de 'novel'”. Essa definição serve ao seu propósito de relacionar a emergência do gênero à Revolução Industrial e à expansão do número de leitores.

8 “[...] A característica mais básica do romance grego (como, em geral, de todo romance) é a capacidade de dialogar com outros gêneros ou, dizendo com mais precisão: uma propriedade que eu não teria receio de chamar de gramatofágica, envolvendo a assimilação e a transformação desses mesmos gêneros" (2005, p.131).

${ }^{9}$ Cf. Reardon (1991) e Fusillo (2006).

${ }^{10}$ Para uma posição diferente, cf. nota 12 deste capítulo em que se menciona Branham (2002). A definição de Brandão, porém, é justificada pela análise de Fócio, que parece ele próprio fazer essa relação ao dizer que As Coisas Incríveis de Além-Tule, de autoria de Antonio Diógenes (cod.166), é "fonte e raiz" não só das Histórias Verdadeiras de Luciano de Samósata mas também de diversos romances de amor. Recentemente Dowden (2009) argumentou contra a tendência de se considerar o texto de Dictis Cretense como uma subespécie do romance.

${ }^{11}$ Desde que os estudos sobre o romance na Antiguidade começaram a se multiplicar e sua complexidade passou a ser reconhecida, não mais do que três décadas atrás, tornou-se inevitável que alguém empreendesse reescrever a história da ascensão do gênero que se tornou predominante da literatura. Doody (1996) recentemente escreveu uma história do romance que desconsidera uma distinção genérica entre a prática antiga e a moderna (e também entre romance e novel), analisando como formas, ideias e motivos dos romances antigos continuam presentes na ficção contemporânea. Contra cf. Branham (2002), que se vale do arsenal teórico de Bakhtin para analisar como a representação do tempo seria diferente em uma e outra prática, o que seria suficiente para haver distinção de gêneros. Para Branham, "literary 
Selden (1994) chamou atenção para a construção histórica e ideológica da classificação das variadas narrativas fictícias em prosa da Antiguidade como "romances". Para o crítico, a origem de uma concepção sistemática do gênero romanesco do período pós-clássico pode ser traçada até o Traité de l'Origine des Romans, de Pierre-Daniel Huet, publicado em 1670, um momento em que o debate estético promoveu as condições a partir das quais se tornou interessante perceber um corpus de ficção antigo coerente. Selden critica, em uma posição solitária, a opção dos estudiosos por uma "conveniência", ignorando as implicações problemáticas do uso do termo novel para a produção da narrativa de ficção da Antiguidade, que seria então inapropriadamente avaliada de acordo com critérios empregados para análise do romance moderno. ${ }^{12}$ Ainda que não pareça possível ou necessário deixar de utilizar um termo anacrônico para classificar determinados textos sobre os quais os antigos não realizaram qualquer reflexão teórica, reconhecer os problemas que podem decorrer de sua identificação com o romance moderno é de fato essencial para que não se leve para a leitura de textos antigos pressupostos e expectativas que lhes são estranhos.

\section{$\underline{\text { I.1 Contextos }}$}

\section{I.1.1 A (falta de) teorização na Antiguidade}

Embora os tratados de retórica do período imperial preencham uma lacuna considerável no que diz respeito à teoria do romance na Antiguidade, há uma completa ausência de discussões teóricas específicas do gênero e uma escassez de testemunhos contemporâneos ao período em que a forma deve ter tido seu auge. Nas extensas obras de Luciano e Plutarco, por exemplo, nada se diz sobre o romance de amor, o que parece

history needs finer distinctions, not fewer categories" (p.163). O crítico também não aceita que sejam agrupados sob um mesmo gênero tipos variados de ficção em prosa do período pós-clássico, como as Histórias Verdadeiras, Quéreas e Calírroe e o Satíricon.

12 O exemplo dado por Selden são os estudos da caracterização dos personagens nos textos antigos, que com frequência expressariam juízos de valor favoráveis a um tipo de caracterização que se cristaliza como norma nos romances modernos a partir do século XVIII (op.cit., p.45-47). 
evidenciar a posição marginal que a produção dessas histórias eróticas possuía no período.

Entre os poucos possíveis testemunhos, há um de Filóstrato que talvez mencione Cáriton de Afrodísias, inserido em uma da série de cartas imaginárias que o autor escreveu endereçadas em alguns casos a pessoas mortas. Esse é um dos documentos que possivelmente atestam a falta de prestígio do gênero. A brevíssima epístola 66 merece ser citada integralmente:

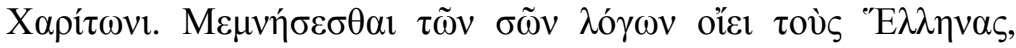

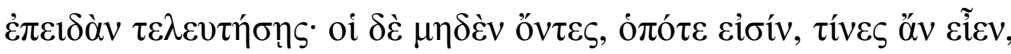

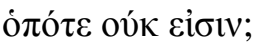

A Cáriton. Pensas que os gregos se lembrarão das tuas palavras, quando estiveres morto; mas os que são um nada quando vivos, o que poderiam ser quando não mais vivos?

Não é possível ter certeza de que o Cáriton aí mencionado seja o nosso autor de Quéreas e Calírroe, mas é bastante provável, já que não se conhece nenhum outro autor da Antiguidade com o mesmo nome. Reardon (1991, p.49) apresenta também outro argumento favorável para a identificação: como Filóstrato era uma espécie de biógrafo da Segunda Sofística, tendo escrito a obra Vidas de Sofistas, o crítico acha muito provável que ele fosse um "literary snob", que veria com maus olhos o tipo de história escrita por Cáriton. É importante ressaltar, no entanto, que embora Filóstrato assuma uma postura crítica, seu testemunho indica que Cáriton era lido pelo seu círculo de leitores. Outro provável testemunho é o do imperador Juliano, já do século IV (Epístola 89b345-9), que afirma a utilidade da historiografia, mas diz que

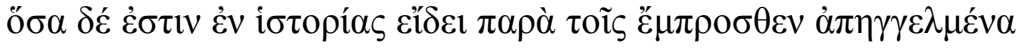

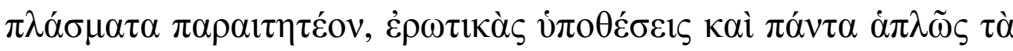
$\tau \operatorname{cov} \tau \alpha$.

Devem ser rejeitadas todas as ficções $(\pi \lambda \alpha \dot{\sigma} \sigma \alpha \tau \alpha)$ compostas por autores do passado na forma de história, temas amorosos e todo esse tipo de coisa. 
Também há controvérsias se nessa passagem Juliano estaria mesmo falando do romance, ${ }^{13}$ embora ela tenha sido tradicionalmente interpretada dessa forma. No caso de Juliano, a censura ao romance trata especificamente da questão da utilidade das leituras; a historiografia, um gênero por ele aprovado, lida com fatos reais, não com fatos inventados narrados em forma de história, seja nos romances de amor, seja em textos que apresentam muito de pseudo-historiografia. ${ }^{14}$ Se Juliano estiver, de fato, falando do romance, ele chama a atenção para uma característica do gênero que é inovadora e que podia provocar mal-entendidos na sua recepção: o romance é uma ficção em forma de história porque com a historiografia ele compartilha temas e técnicas, na tentativa de manter a narrativa dentro dos parâmetros de realidade dos leitores e assim estabelecer sua crença ficcional: "os romances gregos, quase sem exceção, buscam a autoridade e autenticidade historiográfica tendo em vista sua capacidade de serem críveis" (Morgan, 2010, p.555). ${ }^{15}$ Mais do que pela semelhança temática, porém, a relação entre romance e historiografia era baseada no fato de que o primeiro é uma narrativa em prosa, então o meio utilizado exclusivamente para veicular conteúdo verídico, didático ou filosófico. A ficção com fins de entretenimento até então estava limitada à poesia e é bastante provável que a adoção da prosa por parte de autores interessados em produzir textos cujo objetivo principal não era didático não tenha sido bem-aceita de início.

É verdade que é necessário relativizar as afirmações feitas acima, uma vez que na prática historiográfica helenística parece ter predominado uma tendência, já observável em Heródoto, de privilegiar certos elementos patéticos utilizados para suscitar prazer na audiência, além do conteúdo paradoxográfico, cuja importância teria se intensificado com a expansão do conhecimento geográfico após as conquistas de Alexandre, perdendo o aspecto político seu papel central. ${ }^{16}$ Isso, porém, era frequente motivo de crítica e a prática, ainda que corrente, não era recebida pelos leitores educados sem reprovação. De qualquer forma, os romancistas desenvolvem narrativas

\footnotetext{
${ }^{13}$ Cf. Whitmarsh (2005).

${ }^{14}$ Há um testemunho do romance latino que é um provável paralelo do de Juliano. Macróbio, autor do século V, declara que (In Somnium Scipionis 1.2.7-8): “O ouvido deleita-se com as comédias do tipo que Menandro e seus imitadores produziram, ou com narrativas realísticas (argumenta) cheias de aventuras fictícias de amantes, às quais Petrônio se dedicou e Apuleio [...]. Todo esse tipo de histórias (totum fabularum genus), cujo único objetivo é deleitar o ouvido, um tratado filosófico bane de seu santuário”.

${ }^{15}$ Cf. Morgan (1993 e 2010).

${ }^{16}$ Cf. Gabba (1981). Para relação entre elementos ficcionais e historiografia, cf. Morgan (2010).
} 
que têm vários pontos de contato com a historiografia para contar a banal história de como um casal se apaixona e enfrenta uma série de dificuldades até o final feliz. Por isso, um dos motivos que Reardon (1991, p.42-53) observa para explicar a falta de teorização sobre a prática do gênero na Antiguidade é o fato de que o romance "invadiria" um mundo intelectual, provocando ressentimento. A análise do crítico, contudo, leva em conta outras importantes características: os romances são centrados na vida do indivíduo comum, são sentimentais e são fictícios.

Os três aspectos aparecem combinados também na comédia nova de Menandro e isso não impediu o comediógrafo de se tornar um dos favoritos no período, ainda que não se possa perder de vista que a comédia nova não era apreciada sem ressalvas em círculos letrados, do que resultou o conhecido problema da preservação das obras do comediógrafo. Plutarco, no entanto, escreveu um texto para justificar por que ele era seu favorito, mais do que Aristófanes. ${ }^{17} \mathrm{O}$ que diferencia, então, os dois tipos de prática literária, influenciando a sua recepção? Para Reardon, trata-se de uma questão de gosto. O romance carrega nas tintas, tornando-se muito mais violento e sensacionalista: "obstáculos à felicidade tornam-se perigo de vida... o tom levemente romântico tornase sentimentalismo puro, a ambientação doméstica é substituída por terras exóticas " (1991, p.52). As situações são tão exageradas que provocariam resistência crítica e disso teria resultado o fato de que os romances não foram vistos como objetos dignos de análise intelectual.

Bowie (1994), porém, tratou de relativizar esse constrangedor silêncio dos antigos, observando que os gêneros literários foram estabelecidos por eruditos alexandrinos e nem os hinos em prosa de Élio Aristides nem os diálogos satíricos de Luciano puderam na Antiguidade receber uma classificação genérica. Por outro lado, Demétrio, Dionísio de Halicarnasso e Longino escrevem antes do florescimento do gênero romanesco, ao passo que Téon e Hermógenes quase só mencionam autores clássicos em seus manuais. É possível que a falta de teorização do romance seja reflexo dessa soma de circunstâncias, não de um desinteresse ou de um mero esnobismo literário, uma hipótese que parece bem provável. De fato, mesmo sobre Luciano, cuja

\footnotetext{
${ }^{17}$ Moralia, Comparação entre Menandro e Aristófanes.
} 
extensa obra foi bem preservada, acreditou-se até 1976 não haver qualquer testemunho de algum de seus contemporâneos. ${ }^{18}$

Contudo, se não há palavra nem grega nem latina para nomear a prática literária que se convencionou chamar "romance antigo", diversos termos teóricos são empregados pelos próprios romancistas e posteriormente pelos bizantinos. Capilupo (2006) empreende analisá-los, a fim de observar se, de fato, não havia uma terminologia específica para o gênero. ${ }^{19}$ Trata-se de um grupo de palavras relativamente extenso que

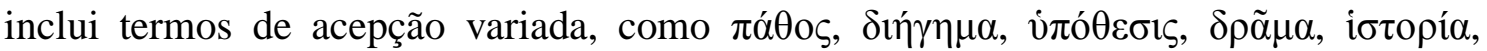

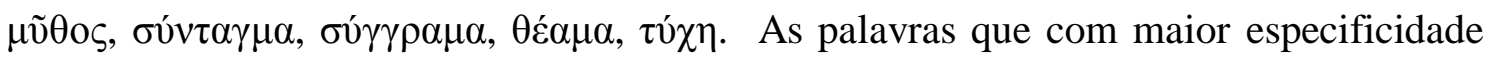
apontam para uma dimensão teórica dos romances, contudo, estão no campo semântico

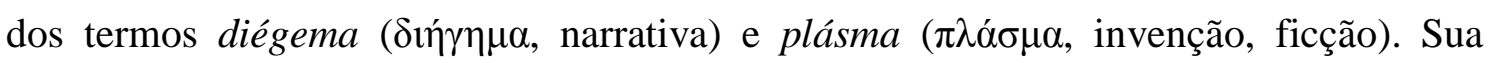
conclusão é de que o termo mais provavelmente empregado para identificar o gênero seria "narrativa", diégema, ora no composto diégema plasmatikón (narrativa fictícia), ora no diégema dramatikón (narrativa dramática). ${ }^{20}$

Não me parece, contudo, que seja possível afirmar que a terminologia do romance "não é vaga e indistinta", como Capilupo conclui a partir da sua investigação, na qual a leitura de Fócio é peça-chave. Para Capilupo, o patriarca bizantino se valeria do termo dramatikón, ${ }^{21}$ por exemplo, não apenas com relação ao caráter dramático (no sentido genérico de "teatral") do romance, mas também como forma de se referir ao caráter dramatizado das histórias, que apresentam grandes partes dialogadas alternadas com seções narradas em terceira pessoa. Aí Fócio estaria utilizando critérios que, em última análise, remontam à discussão platônica sobre o discurso poético (República

\footnotetext{
${ }^{18}$ Em uma tradução de Galeno para o árabe, há uma anedota sobre como Luciano teria forjado um livro com ditos muito obscuros atribuindo-o a Heráclito, levando-o então a renomados filósofos de seu tempo em busca de interpretação. Seu objetivo era fazê-los passar ridículo. O testemunho foi reconhecido por Strohmaier (1976).

${ }^{19}$ Capilupo discute também os proêmios e epílogos dos romancistas, nos quais encontramos termos

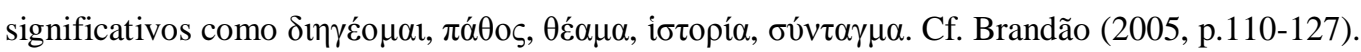

${ }^{20}$ Op. cit., p.134: "Dunque, per quanto concerne la questione della denominazione dei 'romanzi'antichi greci e latini, possiamo definirli, servendoci dell'espressione che maggiormente usavano gli antichi,

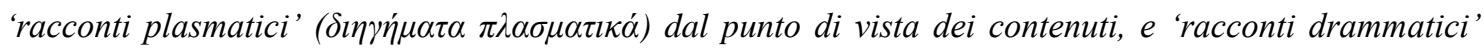

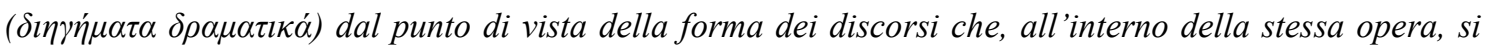
presenta come 'diegematica' e 'drammatica'”.

${ }^{21} \mathrm{O}$ adjetivo é utilizado para Antonio Diógenes (cod.166), Iâmblico (cod.94), Aquiles Tácio (cod.87) e Heliodoro (cod.73).
} 
392d-394c), com a divisão das narrativas em miméticas, simples ou mistas, que foi posteriormente retomada e alterada por Aristóteles, que então analisa a mímesis como diegética, dramática e complexa. É curioso, no entanto, que Capilupo sugira como expressão definidora do romance o "diégema dramatikón" a partir desse critério, uma vez que evidentemente o romance se vale da narrativa mista, ainda que em algumas obras o discurso direto seja quase predominante. Mais interessante seria supor, como faz Ruiz-Montero (1996), que o adjetivo tem aí outro sentido, apesar de ser teatral na origem, e deva estar relacionado às intrigas da narrativa. ${ }^{22}$

A expressão diégema plasmatikón, por sua vez, talvez seja mais apropriada. Ao utilizar plásma, "coisa inventada", com referência ao que narra Antônio Diógenes em As Coisas Incríveis de Além-Tule e Iâmblico nas Babilônicas, Fócio parece fazer uso da terminologia dos manuais de progymnasmata, que tratam de processos de composição certamente relevantes para a produção romanesca do período imperial. ${ }^{23}$ Neles, a narrativa é, de modo geral, definida como "exposição de um fato acontecido ou dado

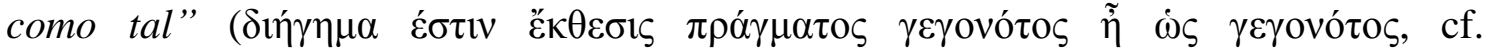
Hermógenes 2.1 e Téon, 78.16). ${ }^{24}$ Hermógenes faz após sua definição uma tipologia do

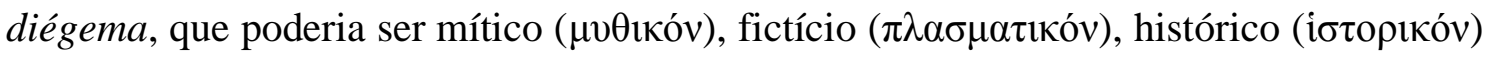

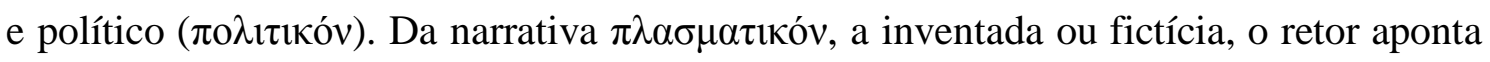
como exemplo a poesia dramática. Desse modo, se diégema plasmatikón era a expressão utilizada na Antiguidade para classificar a poesia dramática, falta-lhe justamente a especificidade de que o plásma, aquilo que é inventado, diz respeito a um texto em prosa, característica distintiva das narrativas que aqui nos interessam. De qualquer forma, dentre as possibilidades que a Antiguidade nos legou, diégema é, sem dúvida, o termo mais adequado para nomear o que chamamos de romance. ${ }^{25}$ Ele é o

${ }^{22}$ É também a opinião de Holzberg (1995, p.5): “the structure of some of Euripides' later tragedies and, more especially, of all extant comedies by Menander, Plautus and Terence is dictated by the tangled fortunes of two lovers happily joined together only at the end of the work".

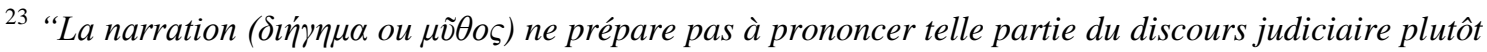
qu'à écire un livre d'histoire" (Bompaire, 1958, p.241). Para uma discussão sobre a narrativa na retórica antiga e sua relação com a crítica moderna, cf. Pinheiro (2000).

${ }^{24}$ Definição semelhante pode ser encontrada em Cícero (De Inuentione, 1.27), na Retórica a Herênio (1.4) e em Quintiliano (IV.2.31ss, "narratio est rei factae aut ut factae utilis ad persuadem expositio").

${ }^{25}$ Capilupo também sugere que o termo latino correspondente ao diégema plasmatikón seria fabula. Porém, na tipologia proposta por Quintiliano, parece-nos que argumentum seria provavelmente o termo mais apropriado, por considerar a verossimilhança da narrativa. Quintiliano (Inst. Or.2.4.2), além da 
mais frequente em Cáriton quando se faz referência ao próprio enredo e Tilg (2010, p.198-238) defende que o autor parte da categoria diégema da maneira como é apresentada nos progymnasmata como uma ferramenta de análise na construção da sua história. O crítico ainda discute os usos da palavra e de seus cognatos em Heliodoro, Xenofonte e Aquiles Tácio para argumentar que esse era o termo empregado na Antiguidade para se referir aos romances e sugere, por fim, que o título do texto de

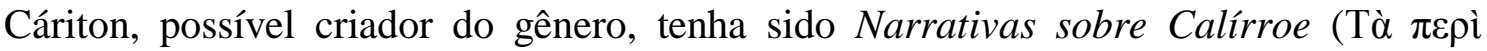

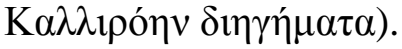

\section{I.1.2 O problema das origens}

Se o romance é uma prática sem teorização na Antiguidade e se nossa visão de um corpus coerente do gênero é de fato estabelecida sobretudo pela influência de Pierre-Daniel Huet e seu Traité de l'Origine des Romans, a investigação moderna sobre a prosa de ficção antiga tem seu marco com a publicação em 1876 de Der Griechische Roman und Seine Vorläufer, de Erwin Rohde. Aqui se pretende fazer resumidamente o relato do percurso da crítica especializada do romance grego até a atualidade, uma vez que a questão das origens dominou por muito tempo o debate crítico sobre romance. Leitor de sua época e ignorante dos dados que as descobertas papirológicas trariam à tona algum tempo depois, Rohde, que passara dos trinta anos de idade não muito antes da publicação da obra, faz uma análise que, embora seja uma demonstração da sua erudição ímpar, é bastante equivocada em suas conclusões. Suas ideias, contudo, foram muito influentes e apontaram o caminho pelo qual a crítica seguiria por várias décadas. A postura de Rohde, além disso, é exemplar de uma falta de apreciação do gênero até

narratio que faz parte do discurso forense, aponta outros três tipos de narrativa, apresentando-as de acordo com sua relação com a verdade: a fabula, que não apenas não é verdadeira, mas também distante da verdade, como a tragédia e as obras em verso; o argumentum, que é falso, mas verossímil, do qual é exemplo a comédia e, por fim, a historia, que faz a exposição de um fato acontecido. Com efeito, se Capilupo elege fabula como termo latino provável para designar o gênero a partir da maneira como os próprios romancistas latinos se referem às suas narrativas, é possível que ela esteja perdendo de vista o tom ironicamente autodepreciativo com que utilizam o termo, analisado recentemente por Graverini e Keulen (2009). 
hoje existente, ainda que o número de publicações sobre o romance tenha crescido exponencialmente nos últimos vinte anos.

O desdém de Rohde por seu objeto de estudo não era pequeno e a questão que movia seu interesse era desvendar como esse gênero havia "surgido" a partir da combinação de outros gêneros literários pré-existentes. Trata-se de uma leitura de viés evolucionista, por assim dizer. A tese do estudioso alemão era a de que o romance seria produto da prosa praticada em exercícios retóricos, que teria permitido o "cruzamento" entre a poesia erótica alexandrina e os relatos de viagem helenísticos. Combinados elementos dessas duas práticas literárias pelos alunos de retórica do período imperial teríamos tido como resultado o romance de amor e aventura. Os hoje datados pressupostos de Rohde fizeram-no estabelecer uma cronologia incorreta para os romances que conhecemos; o texto de Cáriton de Afrodísias, atualmente considerado nosso exemplar mais antigo, foi por ele reconhecido como o último dos romances, uma vez que a simplicidade de sua narrativa assinalaria a tal "decadência" do gênero. Por ter estabelecido uma cronologia equivocada para os textos, Rohde não teria como entender nem a relação do romance com a sociedade que primeiro o produziu nem de que forma as narrativas se relacionavam entre si.

A contestação definitiva da tese de Rohde foi feita apenas em 1967, por Ben Perry, em The Ancient Romances: a Literary-Historical Account of their Origins, cujo título anuncia uma grande mudança de perspectiva, ainda que alguns dos postulados do crítico alemão já tivessem sido anteriormente questionados. ${ }^{26}$ Dialogando diretamente com a análise feita por Rohde, Perry, cuja escrita vivaz rendeu expressões que se tornaram marcantes e que são recorrentes sempre que se fala da fortuna crítica do romance grego, posicionou-se contra um tipo de abordagem característico do final do século XIX que ele exemplificou da seguinte forma (op. cit., p.20):

Pelo mesmo método e lógica pelos quais o romance deriva de exercícios escolares, pode-se derivar a palavra 'smile' da palavra 'mile'; a primeira contém todos os elementos da última, mais o $\mathrm{s}$, o que pode ser explicado graças a um 'desenvolvimento'; e, quanto ao significado da combinação como um todo, ora, nem pense sobre isso!

\footnotetext{
${ }^{26}$ Sobre a contribuição dada por Perry aos estudos do romance antigo, cf. Reardon (2006).
} 
Embora Perry exagere na sua ojeriza pelo termo "desenvolvimento" (development), que designa meramente uma sucessão perceptível nas práticas literárias da Antiguidade, ele aponta o dedo para o que considera uma grande falha do estudo de Rohde, que desconsidera a situação histórica que teria motivado a criação desse novo gênero poético. Igualmente por ele criticados foram os autores que defenderam a então forte hipótese de que o romance teria se originado da historiografia helenística, em um processo de degeneração, Zersetzung, o que Perry chamou com sua verve típica de "uma doença da historiografia”. Como bem observa o crítico, não há como um gênero literário dar origem a outro sem que ele tenha que negar a sua própria razão de ser, "passando por um grau zero".

A grande contribuição crítica dada por Perry foi levar em consideração a configuração histórico-social na questão da origem do romance. Independentemente das revisões pelas quais as ideias de Perry passaram, ele acrescentou ao debate crítico a ideia fundamental de que para o surgimento do romance foi preciso um motivo, mais do que elementos formais disponíveis para sua composição. Não se tratava de reconhecer partes literárias que teriam se combinado formando um novo gênero, mas de perceber como causa desse fenômeno novos impulsos da sociedade grega, cujos anseios não estavam mais representados nos gêneros literários então existentes. Assim, o romance foi visto por ele como uma épica tardia e popular, concebido em razão da demanda por um novo tipo de literatura que atendesse às necessidades e gostos de uma nova sociedade.

Perry advogou por uma criação consciente e individual do gênero romanesco, produto da mente de um autor que inaugura o gênero na infame terça-feira de julho. ${ }^{27}$ Mas, de fato, como observa Brandão (2005, p.161), a criação do romance não depende meramente de um esforço individual, já que nossa perspectiva de gênero baseia-se em um grupo de textos. Talvez por isso, Perry dê pouca atenção para os exemplares do romance grego chamados sofísticos, detendo-se mais na análise daqueles que representariam seu início. Outra conclusão que será mais bem discutida na seção seguinte deste capítulo é a de que o romance era uma forma literária popular, que se adaptou ao "gosto e ao entendimento de pessoas incultas ou frívolas" (op. cit., p.5).

\footnotetext{
27 "The first romance was deliberately planned and written by an individual author, its inventor. He conceived it on a Tuesday afternoon in July, or some other day or month of the year" (op.cit., p.175).
} 
A percepção de que o contexto histórico-social do período helenístico propiciou o desenvolvimento desse novo gênero literário foi uma ideia influente que só começou a ser questionada trinta anos depois (Bowie, 1996 e, principalmente, 2002). Mesmo aqueles críticos que defenderam o caráter sofisticado do público-leitor do romance desde as origens não ignoraram a ideia fundamental do livro de Perry de que o gênero incorporou algo da relação que a sociedade que o produziu sentia com relação ao mundo. Hägg (1983, p.87), partidário da maior parte das conclusões do crítico americano, observa que "não há dúvida de que o romance se enquadra bem no contexto helenístico, ao menos com relação às condições externas: viagem por terra e mar, piratas e bandoleiros, raptos e escravidão, os desastres do destino, sincretismo religioso".

A mesma análise havia sido feita por Reardon (1971, p.323), que vai além nessa observação de que a sociedade helenística ofereceu as condições necessárias para a produção do romance de amor e aventura:

\footnotetext{
Para que o romance nascesse, era necessário um ambiente no qual houvesse interesse no destino do indivíduo, em oposição àquele no Estado, e no amor. Era necessário um quadro geográfico suscetível à expressão desse destino, desse amor, em termos de viagens, separações e reuniões. Era necessária uma sociedade suscetível a inventar uma nova forma literária e que ao mesmo tempo se valesse da longa herança literária grega. Era necessária, finalmente, uma sociedade pouco erudita, pouco literária. Não é possível que escape à observação que esses dados são do mundo helenístico.
}

Reardon destacou a importância das ideias de Perry e a partir delas formulou novas hipóteses sobre a origem do romance. O americano observou que ainda que a influência de um Zeitgeist helenístico na formação do gênero fosse amplamente aceita, nem por isso se havia deixado de procurar um candidato que pudesse ser ancestral principal do romance, como fez primeiramente Rohde, ao eleger uma paternidade dupla da poesia erótica alexandrina e das narrativas de viagem. Que se tivesse sugerido também a épica e a historiografia era uma clara indicação de que se tratava de um 
gênero híbrido, que marcava a sua apropriação de elementos de quase toda a tradição literária grega.

Ao investigar aquilo que Reardon prefere chamar não de "origens", mas de "natureza essencial" do gênero, o crítico destacou um aspecto que se mantém o mesmo em todos os exemplares de narrativas de ficção que possuímos: todos são escritos em prosa. Trata-se de uma característica inovadora, como já se mencionou, uma vez que a literatura fictícia sem intenção didática era então teoricamente restrita à poesia. Assim como Perry, Reardon acredita numa simplicidade inicial do romance, da qual a prosa é um aspecto essencial. Dar importância central ao caráter prosaico do romance na análise do gênero é uma atitude acertada do crítico, ${ }^{28}$ ainda que a partir daí tenham sido tiradas conclusões um tanto polêmicas, mas que foram no seu tempo influentes.

Já em 1927, Kerényi havia argumentado por uma contribuição importante da literatura oriental na formação do romance, às vezes até mesmo desconsiderando modelos gregos em seu favor. Reardon não perdeu de vista essas duas matrizes, mas aceitou a hipótese de Barns (1956) de que o modelo principal do protos heuretés do romance poderiam ter sido os relatos egípcios de aventura e amor. Um exemplo disso seria o fragmento de Sonho de Nectanebo, descoberto em 1839 e datado do século II a.C. Trata-se de uma tradução grega do início de uma história preservada no Romance de Alexandre de Pseudo-Calístenes, a da paternidade de Alexandre, o Grande, atribuída ao faraó egípcio Nectanebo, que teria seduzido Olímpia disfarçado do deus Ammon. ${ }^{29}$ Os problemas com essa hipótese eram muitos, a começar pelo fato que se poderia argumentar, como o próprio Reardon observou, que teríamos aí um Romance de Alexandre egípcio e que voltaríamos então à ideia de uma desintegração da historiografia na origem do romance. Além disso, esse fragmento possui diferenças significativas com os daquele que alguns, como o próprio Perry, consideravam o mais

\footnotetext{
${ }^{28}$ Essa percepção é por ele atribuída a Lavagnini em estudo publicado em 1950.

${ }^{29}$ Cf. Perry (1966). Nectanebo foi o último faraó egípcio, destronado por Artaxerxes III em 343 a.C. e aparece no texto de Pseudo-Calístenes como o pai de Alexandre Magno, que nele reencarna. O papiro teria conservado o início da história, em que o faraó em sonho descobre que Onuris-Ares está descontente porque ele não teria terminado o seu templo. Nectanebo então contrata o melhor escultor para concluir a obra, mas antes que ele dê início ao trabalho, encontra uma bela mulher. O fragmento se encerra aí, mas se supõe que a narrativa seguiria com um episódio amoroso que levaria à não conclusão das obras no templo e consequentemente à ira divina, que talvez explicasse a destituição de Nectanebo do poder e sua fuga para a Etiópia e Macedônia.
} 
antigo romance grego, Nino. Também não se sabe a importância que o elemento erótico teria tido na narrativa, se seria apenas episódico ou estrutural como nos romances. De qualquer forma, Reardon defendeu, seguindo Barns, que os gregos utilizaram a prosa para traduzir histórias egípcias (e orientais), o que para ele teria sido suficiente para lançar a "carreira do romance". Essa base de histórias mais ou menos fictícias, em prosa, teria permitido aos primeiros romancistas helenizar a forma literária, nela inserindo elementos vários da tradição grega. Isso explicaria também a forte presença da cultura egípcia nos romances, uma vez que eles teriam sido escritos para um públicoleitor grego vivendo no Egito. A via formal encontrada para o nascimento do romance teria sido a tradução.

A tese de Reardon, que também incluía uma interpretação do romance como o mito do Helenismo tardio, no qual o viajante solitário busca o par amoroso que dá sentido a sua vida, contudo, foi posteriormente refutada com base na cronologia dos fragmentos, no tratamento dado aos temas, e no fato de que nosso exemplar íntegro mais antigo, o de autoria de Cáriton de Afrodísias, não tem nenhum episódio ambientado no Egito e parece ser claramente produzido na Ásia Menor. ${ }^{30}$

No final dos anos 1970, outra possibilidade foi levantada por Scobie (1979), que sugeriu que contadores de histórias profissionais, fabulatores, teriam tido papel importante no desenvolvimento inicial do romance. Ainda que as histórias por eles contadas e seus aspectos narrativos possam ter sido influentes na configuração do gênero, é difícil considerar a possibilidade de uma origem oral quando novamente Cáriton, em Quéreas e Calírroe, vale-se de modo tão claro da imitação de Tucídides e Xenofonte para a criação da ambientação histórica de sua narrativa. A última grande tentativa de se estabelecer as origens do romance foi feita por Anderson em 1984, que traçou a trajetória de elementos da literatura oriental até o romance grego, mas suas ideias foram recebidas com ceticismo. Não à toa, a questão das origens deixou de ser o problema central dos estudiosos e, em 1993, Bowie e Harrison chamaram-na de "uma investigação vã e insolúvel".

O próprio Bowie (2002), porém, uma década mais tarde lançaria ideias que resultaram em uma nova percepção sobre a origem do romance, hoje relativamente corrente. Ao discutir a cronologia dos primeiros romances e de alguns fragmentos, Bowie chegou a uma datação provável em que todos eles seriam produtos do século I

\footnotetext{
${ }^{30}$ Cf. Stephens e Winkler (1993, p. 12-18) e Ruiz Montero (1996, p. 146-50).
} 
d.C.: Cáriton de Afrodísias teria sido escrito entre 41-62 d.C., Nino entre 63-75 d.C., Xenofonte de Éfeso pós-65 d.C. e Metíoco e Partenope, embora tenha uma datação mais difícil de precisar, teria sido escrito em uma data próxima à de Cáriton, a julgar pelas semelhanças de tema e de estilo. O crítico chama a atenção para o fato de que a Ásia Menor pode ser considerada o local de nascimento do romance, pois o autor de Nino também pode ter sido cidadão de Afrodísias, uma hipótese levantada pela primeira vez por Estevão de Bizânio (VI d.C.), já que a cidade anteriormente se chamava Ninoe. Stephens e Winkler (1993) também já haviam sugerido que essa obra, assim como Metíoco e Partenope poderiam ser de autoria de Cáriton. ${ }^{31}$ Além do mais, Afrodísias é o local onde se encontrou o único registro do nome composto Antônio Diógenes nesse período, que é o do autor de As Coisas Incríveis de Além-Tule. ${ }^{32}$

Mais importante do que isso, no entanto, é o fato de Bowie argumentar que todos os textos são produtos do período imperial, a partir dos eventos narrados e de elementos linguísticos, já que até então se considerava como possibilidade que Nino fosse datado do século II a.C., de modo que, a partir dessa nova cronologia, o período helenístico, da forma como haviam imaginado Perry e Reardon, não poderia ser o momento de nascimento do romance. O crítico, como muitos, discorda também da tese defendida por O’Sullivan (1995) de que Xenofonte de Éfeso seria o protos heuretés do gênero, dando o lugar de honra a Cáriton.

As ideias de Bowie foram exploradas com cuidado e com auxílio de um grande arsenal de dados históricos, arqueológicos e epigráficos por Tilg em Chariton the Aphrodisias and the Invention of the Greek Love Novel, publicado em 2010. Nessa nova perspectiva sobre a origem do gênero, tanto Bowie quanto Tilg são categóricos na sua oposição à abordagem de Perry: o primeiro observa que a escolha de eros como tema principal no romance não pode ser explicada pelo contexto social e o segundo defende que o gênero não surge por uma necessidade da sociedade. ${ }^{33} \mathrm{O}$ objetivo de Tilg é

\footnotetext{
${ }^{31}$ As hipóteses são discutidas com detalhe por Tilg (2011), que defende que Cáriton é também autor de Métioco e Partenope, mas não de Nino, baseado principalmente na análise da linguagem e do estilo.

${ }^{32}$ Cf. Bowersock (1994, p.38-40).

${ }^{33}$ Outro exemplo recente dessa postura é Lowe, que defende que o romance é pouco mais do que um desenvolvimento da comédia nova, o único elemento realmente novo sendo a simetria sexual, que ele não acredita estar relacionada ao contexto histórico-social (2000, p.226): "I would suggest instead that the change is determined less by political or ideological changes in the outside world than by primarily narratological factors".
} 
demolir de uma vez por todas as hipóteses anteriores e estabelecer Cáriton como o inventor do romance de amor, salvando uma única ideia de Perry, a de que existiu uma primeira mente criadora do gênero. Ele argumenta que trabalhar essa tese a partir do material conhecido é melhor do que especular sobre algum texto do período helenístico que teria se perdido. Tilg, assim, resume o processo de criação do romance da seguinte forma (op. cit., p.7): "Alguém em algum momento chega a uma fórmula de sucesso e isso é uma invenção. Outros partem desse modelo e isso se torna um gênero”. Embora recentemente alguns críticos tenham sugerido motivos pelos quais o romance de amor teria se tornado essa "fórmula de sucesso", 34 Tilg rejeita todas as hipóteses em favor de uma invenção desconectada do contexto histórico (op. cit., p.10):

\begin{abstract}
Minha opinião é de que o romance de amor não é resultado nem de evoluções ou conflitos de qualquer gênero literário, nem de amplas necessidades culturais. Se um autor - que eu penso ter sido Cáriton - não tivesse inventado a forma de escrita que se tornaria o romance de amor, ninguém teria ficado sabendo ou dado por sua falta.
\end{abstract}

Creio que temos um exemplo inconteste em Luciano de Samósata e suas Histórias Verdadeiras de como um autor pode conscientemente se apropriar de aspectos de gêneros literários pré-existentes para compor um texto que, no final das contas, não pertence a nenhum deles, criando uma forma literária que deixaria seguidores, ainda que não entre seus contemporâneos - a narrativa de viagem fictícia e satírica. Tal pode ter sido o caso também com Cáriton de Afrodísias, cujas influências, segundo Tilg, teriam ainda incluído, com grande importância, os contos milésios e sibáricos ${ }^{35}$ e a Eneida de

\footnotetext{
${ }^{34}$ Konstan (1994) sugere que o romance reflete um momento do período imperial em que o casamento passa a ser visto como independente de interesses públicos. Outros defendem a perspectiva contrária, como Swain (1999), que analisa a ausência de referências a Roma nos textos como indício de que representam a hegemonia das elites gregas por meio do casamento, bem como Lalanne (2006), que percebe nas aventuras romanescas a representação de ritos de passagem de jovens da elite grega à idade adulta.

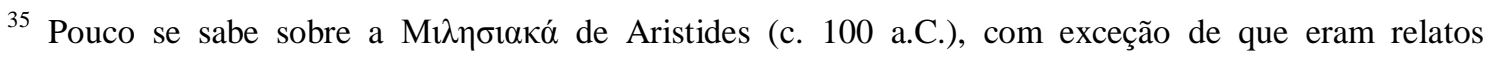
"realistas" de narrativas eróticas relacionadas de alguma forma à cidade de Mileto. Cf. Harrison (1998). Tilg (2010, p.147) acredita que essa forma literária teria conquistado "seguidores", como revelaria a
} 
Virgílio. O crítico, porém, alega que considerar que o romance responde a uma função literária ou cultural significaria ignorar as especificidades de produção de cada um dos romances, voltando-se à perspectiva do gênero como algo homogêneo e de pouca qualidade literária. Não me parece, porém, que algo assim (ainda) aconteça com a comédia nova e com a comédia latina, embora a mudança das condições históricas que tornaram a comédia antiga um gênero obsoleto sejam claras.

Aqui, confesso me identificar com Reardon (2006, p.233) que diz não estar preparado para abandonar por completo a ideia, fundamental para o livro de Perry, de que em suas primeiras manifestações o romance incorporou algo do que a sociedade do final do período helenístico sentia com relação ao mundo em que se vivia. Se o romance de amor, porém, de fato é um produto de uma cidade do século I d.C. favorecida por Roma, Afrodísias, com pouca semelhança com os centros urbanos como imaginados por Perry, ${ }^{36}$ também não me parece um ganho decidir simplesmente desconsiderar as condições históricas que teriam favorecido o florescimento do gênero em favor de uma concepção de criação como insight de um indivíduo que alcançou uma fórmula mágica quase por acaso e que foi imitado por outros autores por nenhuma outra razão que não estética. Novas descobertas de papiros podem em algum momento, como já aconteceu, desestabilizar as estruturas sobre as quais nossa concepção atual das origens do romance foi fabricada, mas eu acredito ser importante, a partir da nova cronologia estabelecida desde o estudo de Bowie (2002), que se continue a pensar o que teria motivado a produção copiosa de romances de amor nesse período da Antiguidade. Ainda que Tilg mencione como necessárias para seu surgimento (op. cit., p.12) “algumas condições gerais de literatura e cultura [...], tais como certa evolução e apreciação da ficção em prosa e certa 'globalização' do mundo mediterrâneo”, ele parece inapropriadamente

Sybaritica, obra mencionada por Ovídio (Trist, 2.147), Marcial (12.95.1) e Luciano (Ind.3, Pseud.23), de autoria de certo Hemitheon.

${ }^{36}$ Perry (1967, p.48): "In the vastly expanded world of Hellenistic and Roman times the individual lost nearly all his quondam importance and representative significance, having become too tiny to be tragic, or heroic, or poetic, or symbolical of anything more than himself [...]. The bigger the world the smaller the man. Faced with the immensity of things and his own helplessness before them, the spirit of Hellenistic man became passive in a way that it had never been before, and the regarded himself instinctively as the plaything of Fortune". Tilg enfatiza que a parte "sociológica" da tese de Perry é inválida (op.cit, p.6): “We have come to learn that Hellenistic culture was by no means a valley of tears but a complex, diverse, pragmatic, and overall progressive period. The same goes for the early imperial period, in which our extant novels were written". 
sugerir um criador à parte da sociedade na qual vivia, uma vez que sua concepção de invenção do gênero é relacionada principalmente à "imaginação pessoal" (idem, ibidem).

\section{I.1.3 Os leitores do romance}

As ideias expostas por Perry no final dos anos 1960 confrontaram de forma definitiva a leitura de Rohde, mas em uma coisa os dois críticos concordavam: na concepção de um público leitor das histórias de amor pouco refinado. Para Perry, os leitores dos primeiros exemplares do gênero eram jovens há pouco chegados à puberdade, uma conclusão à qual ele parece chegar baseado não só no forte sentimentalismo das narrativas, mas também na sua suposta falta de qualidade. Embora ponto quase pacífico entre Rohde e Perry, a questão do público leitor hoje é vista de perspectiva diferente e atualmente o romance é considerado uma espécie de leitura de lazer dos eruditos, já destinado desde suas origens a um público não distinto daquele que se dedicava à leitura das obras clássicas. Aqui fazemos um breve histórico de como a nossa percepção acerca do público-leitor do romance se alterou desde o fim dos anos 1960.

A tese de Perry dependia da emergência de uma nova classe de leitores, que o crítico definiu como "pobres de espírito". Essa visão simplista foi reavaliada em vários aspectos nas últimas décadas. Um exemplo é a questão de uma possível leitura feminina do romance, que apenas há cerca de vinte anos passou a ser analisada de uma perspectiva que não percebe as mulheres no grupo de prováveis leitores do romance apenas como exemplo dos ingênuos ou dos pouco educados a quem o gênero supostamente seria dirigido, mas que parte de sólidas orientações investigativas. Hägg (2004a, original de 1994), um dos primeiros na crítica recente a defender a hipótese de que os romances teriam sido concebidos tendo em vista em parte um público feminino, destacou a preocupação dos primeiros exemplares do gênero com as mulheres,

principalmente na representação da sua psicologia, sentimentos e vida privada. Como bem lembrou Bowie (1996), porém, esse argumento, que parte de evidências internas ao texto não procede, já que Eurípides sempre pareceu particularmente interessado na psicologia feminina, mesmo que sua audiência fosse predominantemente masculina. 
Desse modo, no que diz respeito a um suposto grupo de mulheres leitoras do romance, Egger (1999) foi quem lidou com a questão mais detalhadamente, sob duas perspectivas: a primeira, levando em consideração as evidências reais que possam ou não corroborar a ideia de um público feminino letrado e, a segunda, lidando especificamente com a representação das mulheres nos romances na sua relação com o contexto histórico.

Há, de fato, evidências nos papiros de um aumento progressivo do nível educacional das mulheres a partir do século III a.C., ao menos no Egito, e essa situação possivelmente se expandiu para outras regiões helenizadas. Embora nenhuma das heroínas dos romances antigos tenha sido representada como também leitora desse tipo de texto, como as protagonistas dos romances modernos, elas leem e escrevem cartas e Antônio Diógenes em As Coisas Incríveis de Além-Tule diz que o texto foi escrito para sua irmã Isidora, que ama o estudo ( outra menção a uma leitura feminina será feita apenas pelo obscuro Filipe, o Filósofo, autor de uma interpretação alegórica de As Etiópicas, de Heliodoro, que considera a narrativa educativa. ${ }^{37}$ Além disso, os nossos possíveis testemunhos antigos sobre o gênero são escritos por homens, os romances são lidos pelos estudiosos bizantinos e temos até uma recomendação da leitura das histórias de amor, feita no século IV, por Teodoro Prisciano para a cura da impotência masculina. ${ }^{38}$

Quanto às heroínas, Egger observa a tendência arcaizante na representação das relações pessoais e das leis que regiam acordos matrimoniais, algo justificável em alguns dos romances que se apresentam como uma espécie de romance histórico, cujas ações são ambientadas em um passado não recente. No entanto, a crítica percebe nisso uma intenção deliberada dos autores de representar restrições ainda maiores do que aquelas observadas na realidade então presente à condição das mulheres. As heroínas, por sua vez, saberiam ao mesmo tempo utilizar sua irresistível atratividade sexual para controlar o ambiente ao seu redor, sobretudo em situações adversas, mas conseguindo no final manter sua castidade. Desse modo, os romancistas não só promoveriam uma forte identificação dos leitores com a heroína, mas essa representação poderia ganhar aprovação de um público tanto feminino quanto masculino.

\footnotetext{
37 A datação de Filipe é controversa e há grande disparidade nas sugestões: séculos V, VI ou XII. Cf. Hunter (2005).

${ }^{38}$ Cf. Wesseling (1998, p.68).
} 
Essa leitura de Egger, no entanto, pode ser contestada pelo fato de haver episódios e passagens nos romances sofísticos que parecem pouco apropriados para uma leitura feminina, principalmente se forem consideradas as personagens secundárias. Aqui teríamos que considerar que o romance de amor teria se desenvolvido de forma tal a excluir, no breve período entre a produção de Cáriton e Xenofonte de Éfeso (século I d.C.) e os romances sofísticos de Longo e Aquiles Tácio (século II), o público feminino como audiência, o que não parece razoável. Licênion, em Dáfnis e Cloé, é esposa de um fazendeiro vizinho de Dáfnis e é descrita como uma mulher da cidade, sofisticada demais para o campo. Licênion arquiteta um plano (III.15-19) para ter Dáfnis como amante; percebendo sua total devoção a Cloé, ela oferece uma lição prática prontamente aceita - de como realizar o ato sexual, de forma que Dáfnis possa posteriormente se relacionar com Cloé, algo que o casal vinha tentando fazer sem sucesso, por total inexperiência. Há também a passagem de Aquiles Tácio em que Menelau, Clinias e Clitofonte (III.34-8) comparam os prazeres do amor hetero e homossexual, que foi com alguma frequência expurgada das traduções. ${ }^{39}$ Leucipe não presencia essa conversa, por estar oportunamente dormindo.

Como bem observou Brandão (2005, p.170), o grande problema de tentar definir um grupo de leitores para o romance é o fato de que a recepção nem sempre deixa indícios. Assim, uma investigação que leva em conta apenas elementos internos às narrativas ou uma possível representação de um leitor ideal não esgota as possibilidades de leitura (ou audiência) desse texto. Esse é o ponto considerado por Hägg (2004a) para insistir na ideia de um público leitor menos educado dos romances não sofísticos, embora ele considere que não se pode duvidar que as narrativas de Longo, Aquiles Tácio e Heliodoro foram escritas tendo em vista um grupo sofisticado. Hägg observa características típicas da oralidade em Cáriton e Xenofonte de Éfeso e, a partir delas, defende a ideia de que os textos foram pensados para leitores inexperientes ou ouvintes, algo que foi contestado com vários argumentos. Por exemplo, as recapitulações tão frequentes em Cáriton, para além de orientar uma audiência sobre o que já havia se passado na história a fim de tornar o acompanhamento da narrativa mais fácil, podem ter sido utilizadas para orientar os próprios leitores, sobretudo quando se considera a possibilidade de eles terem tido acesso apenas ao rolo em que aquele livro tinha início e

\footnotetext{
${ }^{39}$ É o que diz Winkler na sua tradução do romance na coletânea organizada por Reardon (1989, p.205 nota 40).
} 
não aos outros. Stephens (1994, p.409) menciona o fato de que as fontes antigas registram muitos tipos de performance pública, mas que "nada é dito a respeito da leitura de romances e mesmo o mais breve deles é longo demais para uma recitação pública”.

Stephens (idem) tentou, assim, outro tipo de abordagem ao investigar os restos materiais do romance grego a fim de saber se poderíamos tirar quaisquer conclusões sobre seus antigos donos. Como resultado, a crítica argumentou que a ideia do romance como gênero "popular" era insustentável. Os achados de Stephens demonstram quão pequeno é o número de fragmentos restantes no Egito e copiados entre os séculos I e VI d.C., totalizando meros quarenta e dois (e Stephens ainda inclui na conta os da versão grega de Dictis Cretense). É um número muito pequeno se considerado a quantidade de papiros preservados de Homero e autores clássicos no mesmo período e região. Além disso, Stephens tenta descobrir algum indício sobre a posição social dos leitores a partir da qualidade dos manuscritos e a sua conclusão é de que os rolos e códices não eram diferentes em aparência daqueles dos autores clássicos como Safo, Tucídides, Demóstenes e Platão. Alguns dos textos teriam ainda a aparência de "coffee-table books", com margens largas e boa caligrafia, do que resulta a conclusão de Stephens de que seriam itens dispendiosos. ${ }^{40}$

É preciso, porém, ter em vista o papel do acaso na seleção dos fragmentos supérstites, para não mencionar o fato de que a aridez do Egito possibilitou pontualmente a preservação de fragmentos de textos que devem ter sido lidos em uma região muito mais extensa, principalmente na Ásia Menor, onde o gênero deve ter sido inventado. Levando em consideração os mesmos critérios utilizados na contagem dos fragmentos romanescos, o número de fragmentos de Plutarco não passa de quatro e Luciano e Libânio são representados por apenas um. Stephens argumenta que só se pode concluir que esses autores, assim como os romancistas, eram muito menos lidos do

\footnotetext{
${ }^{40}$ Outra indicação de que os romances seriam apreciados por uma parcela da população com meios de obter instrução são os mosaicos encontrados em Dafne, um subúrbio de Antioquia, em uma casa de relativa opulência datada do período da dinastia Severa (193-235 d.C.). Em um mosaico, estão representados Metíoco e Partenope, com seus nomes inscritos ao lado das figuras, em outro provavelmente Nino, personagem do romance Nino. Não é certo, contudo, que esses mosaicos figurem a representação de personagens romanescos. Há uma passagem em Luciano (Pseudologistes, 25) que menciona Nino e Metíoco como personagens de uma performance teatral e a postura de Metíoco parece indicar que ele está sobre uma espécie de palco. Cf. Quett (1992).
} 
que os autores clássicos. Considerada a grande extensão das obras de cada um desses autores, no entanto, o que resta é de fato muito pouco, e se estiver correta a conclusão da crítica de que os leitores dos romances seriam os mesmos de Plutarco e de representantes da Segunda Sofística, talvez se tenha um indício de que, além de pouco lidos, esses autores eram também menos lidos do que os romancistas. Será que porque os pepaideuménoi preferiam sua leitura de lazer? Ou porque os romances tinham um público leitor mais amplo? Ou ainda porque o acaso fez resistir uma seleção de fragmentos em um número que não é de fato representativo da atividade de leitura da época? Mais do que as evidências materiais, parece que o argumento principal contra uma leitura "popular" do romance deva ser as condições de letramento da época. Já se havia chamado a atenção para o fato de que a capacidade de leitura não tivesse se expandido no período helenístico até as camadas menos educadas da população a um grau que daí pudesse sair uma quantidade expressiva de pessoas que conseguissem se dedicar à leitura como lazer. ${ }^{41}$ Além disso, quando se compara o romance não sofístico com uma literatura de fato "popular" (no sentido de que era dirigida a uma camada menos educada da população), os escritos apócrifos cristãos, a diferença de estilo é enorme (Stephens, op.cit.).

Por outro lado, mesmo que se considere Xenofonte de Éfeso um imitador da "fórmula" de Cáriton de Afrodísias, o fato de ele construir sua narrativa sem os artifícios retóricos observados nos romancistas posteriores e sem exibição de erudição literária talvez aponte para o fato de que a história de um romance era, na época, apreciável por si só e pode ter sido reproduzida por outros autores do período com menor nível de sofisticação. Somando-se a isso o conhecido problema do silêncio sobre o romance na Antiguidade, não podemos tomar a ausência de passagens que mencionem recitais como indício de que eles não aconteceram. Afinal, se dependêssemos apenas dos testimonia e não tivéssemos exemplares e fragmentos supérstites do romance, não poderíamos sequer desconfiar que ele foi praticado na Antiguidade. Além disso, Hägg (2004a) parece ter em mente principalmente audiências privadas dos textos, realizadas em um ambiente doméstico no qual nem todos seriam letrados. De todas essas hipóteses, no entanto, não há registros. Assim, embora levar adiante a ideia de que o romance é meramente uma "leitura de lazer" do homem educado obrigue a imaginar um contexto no qual o "suspense narrativo, o impacto emocional e a função escapista"

\footnotetext{
${ }^{41}$ Cf. Wesseling (1988).
} 
(Hägg, 1994, p.54), parcialmente independentes da sofisticação literária, não alcançaram senão os pepaideuménoi, os indícios que temos acerca dos exemplares conhecidos do gênero não possibilitam argumentar por uma recepção mais heterogênea do que a atualmente imaginada.

\section{I.2 A prática literária}

\section{I.2.1 Apropriações da tradição}

Mesmo que se tenha demonstrado como era equivocada a análise "biológica" da origem do romance, segundo a qual ele teria surgido a partir do desenvolvimento de gêneros literários preexistentes, isso não quer dizer que se estivesse negando que os romancistas gregos se apropriaram de diversos elementos de outras práticas literárias em seu processo de composição. Trata-se apenas de uma mudança de perspectiva: passa-se a entender que a relação com as formas canônicas não é de uma simples dissolução, mas faz parte de um processo criativo de um grupo de indivíduos em diálogo com práticas literárias tradicionais que faz uso de diversos de seus elementos com propósitos vários. Essa capacidade de apropriação e transformação de outros gêneros é característica essencial do romance; basta para entendê-lo ler o primoroso texto de Longo, Dáfnis e Cloé, no qual a poesia bucólica de Teócrito e a comédia nova combinam-se como influências principais, ou o livro IX de Heliodoro, cuja matriz historiográfica é evidente. Isso fica claro também na confusa história da classificação dos fragmentos de romances. Quando se publicou pela primeira vez um fragmento de Sesoncôsis, por exemplo, ele foi identificado como parte de uma narrativa historiográfica e só foi reclassificado quando um trecho maior foi descoberto. Um trecho de Metíoco e Partenope foi de início considerado "filosófico" porque trata do poder do amor nos moldes do Banquete, de Platão (Stephens e Winkler, 1993, p.9).

Em alguns casos, quando há alusões claras ou citações, os autores parecem chamar atenção para um modelo com o qual eles desejam se associar, mas nem sempre a inspiração é evidente. Dessa forma, para o tema amoroso frequentemente são 
enumerados intertextos vários: a relação de Penélope e Odisseu, a poesia lírica e elegíaca dos períodos arcaico e helenístico, a comédia nova, a história de Panteia e Abradatas na Ciropédia, o casal Medeia e Jasão, os tristes relatos amorosos de Partênio, além de outras possíveis fontes. Não temos como saber como o primeiro romancista elaborou a ideia de um casal que se apaixona perdidamente à primeira vista e que só poderá ter seu final feliz quando as aventuras que os separam tiverem fim e seu casamento puder ser celebrado ou retomado. E não podemos precisar que modelos esse autor tinha em mente; assim, se Homero é citado com frequência, por outro lado, em nenhum dos romances se menciona explicitamente Panteia e Abradatas.

Há diversos antecedentes na literatura grega para o elemento erótico como presente no romance, mas novamente a especificidade com que ele é abordado pelos romancistas fez com que eles parecessem insatisfatórios e resultou em uma procura de fontes possivelmente mais apropriadas alhures. Para Winkler (1994), ${ }^{42}$ a concepção romântica da relação matrimonial, estranha ao tempo e à cultura gregos, em que ela seria vista muito mais como um fator social do que algo que atendia aos desejos do indivíduo, e que curiosamente veio a se estabelecer mais tarde como um ideal válido ainda hoje, teria sua origem no Oriente. Winkler, assim, opta por deixar em segundo plano os modelos herdados da tradição literária grega. Trata-se de um procedimento semelhante àquele observável na tese que elegia uma tradição egípcia para explicar como os primeiros romancistas uniram elementos da historiografia e da poesia gregas na forma inovadora da ficção em prosa. Como explicar o que é novo? Em ambos os casos, os críticos achavam que a ideia inovadora (narrativa fictícia em forma de história; amor no casamento) antecede a criação literária no interior da cultura grega; o trabalho dos primeiros romancistas gregos teria sido justamente se apropriar dessas ideias, helenizando-as.

A questão da apropriação da tradição literária não é, no entanto, destinada à aporia como parece ser a das origens do romance e deixa registros claros nos textos, ainda que não possamos reconhecer todos. Os autores das narrativas que possuímos,

\footnotetext{
42 "The narrative pattern of romance is a resident alien in Greek culture, a literary form born in and (presumably) appropriate to the social forms of a Near Eastern culture, and which has been Hellenized in the wake of Alexander's conquests". Ainda que não apresente uma investigação mais profunda do assunto, Winkler defende que a ideia do "amor no casamento" era um elemento artístico plenamente desenvolvido em um momento em que ele não tinha nenhum valor representativo da vida dos leitores e que isso seria uma evidência de que ele tem origem externa à cultura grega.
} 
com exceção possivelmente de Xenofonte de Éfeso, empenham-se para tornar evidente o processo imitativo do qual se valem ao longo da composição e a ocorrência de termos metapoéticos é frequente. É fato que as alusões e citações fazem parte de um trabalho individual de cada um dos romancistas e possuem um grau mais ou menos refinado dependendo do autor, mas no geral se observa o que Fusillo (1991, p.20) descreve como "uma tendência de reescrever em tom trivial a tradição literária, algo que coexiste com a tendência oposta de enobrecer a narrativa”. Assim, o autor (2005) reconhece, por exemplo, nos romancistas gregos e latinos formas diferentes de apropriação da tradição épica. Na vertente latina cômica do romance, representada por Petrônio e Apuleio, seria marcado um distanciamento entre o romance e a poesia épica, gênero elevado. No caso dos gregos, ao contrário, o crítico defende que uma das principais funções da alusão à poesia épica é a de elevar um gênero que, sendo uma prática literária recente, careceria de verniz; esse procedimento seria observável principalmente em Heliodoro e Cáriton. ${ }^{43}$

Para ilustrar o processo por meio do qual são transformados em romanescos elementos de outros gêneros literários citamos um trecho exemplar de Longo (III.33.4), no qual se alude a um poema de Safo:

\author{
Fr. 105a (L-P)

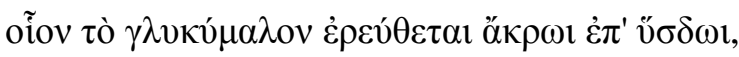

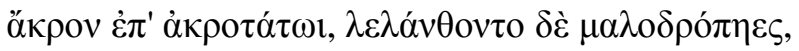

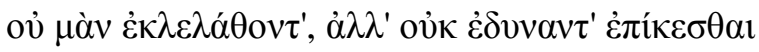

Sozinha, a doce maçã enrubesce no alto ramo, Alto, altíssimo, pois esqueceram-na os apanhadores da maçã. Na verdade, não a esqueceram: não conseguiram foi lá chegar. ${ }^{44}$

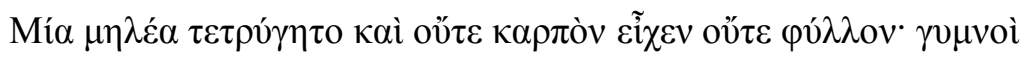

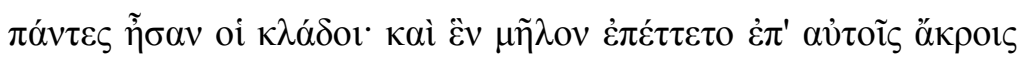

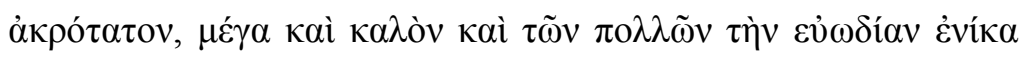

\footnotetext{
${ }^{43}$ Para o crítico, Longo e Aquiles Tácio aludiriam à épica de forma irônica. Em Leucipe e Clitofonte, por exemplo, há apenas uma alusão a Odisseu, quando Sátiro se refere de forma irônica ao servo que impossibilitava que Clitofonte entrasse no quarto da Leucipe como um "ciclope adormecido" e exorta o herói a se mostrar um "valoroso Odisseu” (II.23.2-3). Cf. Fusillo (1989, p.31).

${ }^{44}$ Tradução de F. Lourenço (2006, p.42).
} 


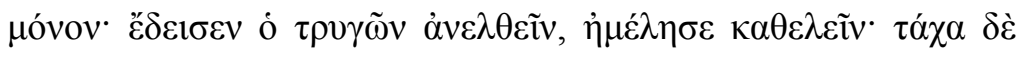

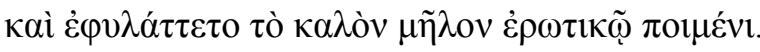

Uma macieira fora colhida e não tinha nem fruto nem folha; os galhos estavam todos nus. E uma única maçã estava amadurecida no mais alto dos altos galhos; era grande, bela e sozinha vencia o perfume de todas as outras. Quem as colhia teve medo de subir, não se importou em apanhá-la. E talvez a bela maçã estivesse guardada para um pastor enamorado.

A história de amor dos pastores Dáfnis e Cloé é ambientada em Lesbos e Safo é uma das principais fontes das alusões de Longo. O fragmento aí aludido faria parte de um epitalâmio, no qual a maçã representaria a virgindade da noiva. ${ }^{45}$ No momento em que essa alusão ocorre, Dáfnis havia acabado de receber uma lição prática de como realizar o ato sexual com a esposa de um fazendeiro vizinho, Licénion. Animado para mostrar a Cloé o que aprendeu, pois eles haviam tentado sem sucesso descobrir o que fazer para satisfazer seu desejo, ele é alertado pela mulher que, por causa da inexperiência, Cloé sangraria e gritaria, o que o deixa então receoso e posterga a consumação do sexo para o momento apropriado, i.e., após o casamento, acordado pelas duas famílias citadinas dos pastores, após o seu reconhecimento. "Imediatamente antes do episódio da maçã (...) Dáfnis havia falado pela primeira vez de Cloé como sua esposa: o leitor é então levado a ler o episódio como antecipação da projetada noite do casamento”(Morgan, 2008, p.235).

Alguns desses elementos literários reelaborados, porém, apontam para uma contribuição na própria estrutura narrativa do gênero ou para suas convenções. São esses em especial que nos interessam aqui. A intenção não é fazer uma discussão vasta das relações intertextuais do romance grego, mas apenas uma apresentação pontuada de exemplos dessa que é uma das características mais próprias do gênero. ${ }^{46}$ Também não se pretende passar em revista todas as possíveis fontes dos romancistas, provavelmente mais variada e multicultural do que se possa dar a entender, uma vez que nossa

\footnotetext{
${ }^{45}$ Segundo Himerios (Or.9.16). Cf. Morgan (2004, p.221).

${ }^{46}$ Para discussões mais abrangentes, cf. Hägg, (1983); Fusillo (1991); Ruiz-Montero (1996) e Morgan (2008).
} 
discussão é centrada no que é tomado da tradição literária grega e não levará em conta influências externas ou de práticas populares.

Por causa da temática amorosa, a influência da poesia lírica na formação do romance foi vista como essencial por Rohde, que a elegeu como uma das duas matrizes principais do gênero. Aqui se tem em mente principalmente a elegia alexandrina, que dá ao amor uma dimensão narrativa da qual é um bom testemunho a coleção em prosa de Partênio de Nicéa (séc. I a.C.), cujas histórias quase sempre trágicas teriam mais tarde fornecido material para as elegias latinas. $\mathrm{O}$ encontro em uma festa religiosa, o amor à primeira vista, a paixão vivida como uma doença, o juramento de fidelidade, todos esses elementos tópicos do romance teriam sido tomados da elegia alexandrina. Para Rohde, porém, o elemento erótico teria se fundido à estrutura das narrativas de viagem. Um exemplo importante desse tipo de gênero teria sido Iâmbulo, cuja obra é conhecida apenas por um resumo feito por Diodoro Sículo (II.55-60). ${ }^{47}$ A narrativa de Iâmbulo apresenta semelhanças com a série de aventuras apresentadas nos romances, como a captura por piratas durante uma viagem. Lugares-comuns como a tempestade e o naufrágio e a forte presença da paradoxografia seriam outros pontos de contato com o romance.

Como narrativa de extensão razoável, episódica e de tipo misto, porém, o romance se relaciona principalmente com a épica e com historiografia. Os críticos concordam sobre a importância da Odisseia para a configuração do gênero, a ponto de Fusillo (1991, p. 24ss) afirmar que, deixada de lado a distinção entre verso e prosa, seria possível afirmar que o poema de Homero é o "primeiro romance grego". A identificação da Odisseia com o romance ${ }^{48}$ advém não apenas do seu tema, que conjuga aventuras e união no casamento, mas também da forma como é elaborada e estruturada a narrativa. O primeiro aspecto, que se trata de ficção, é tão evidente que pode passar por desimportante, mas aqui vale lembrar que quando Aristóteles afirma na Poética que não é em metrificar ou não que diferem historiador e poeta (1451b), embora se preveja a possibilidade da ficção em prosa, ela ainda demoraria alguns séculos para surgir.

Algumas técnicas narrativas estabelecidas pela poesia homérica são empregadas nos romances, como o narrador-personagem de Aquiles Tácio ou de

\footnotetext{
47 Sobre Iâmbulo, cf. Holzberg (1996).

${ }^{48}$ Não se pretende discutir concepção hegeliana de romance como epopeia burguesa e secularizada. Para uma discussão do assunto, cf. Fusillo (1991 e 2006). A tese de Perry também é a de que romance e épica são o mesmo gênero, com características diferentes justificáveis pela época em que são produzidos.
} 
Heliodoro (Calasíris), do qual o protótipo é Odisseu e seus apólogoi na corte de Alcínoo. Outro exemplo é a forma de apresentação de ações paralelas, que na épica pode ser observada na divisão entre os planos humano e divino, e que tem de resolver o problema de inserir em uma narrativa que flui em uma única direção acontecimentos que se passam simultaneamente. Se Homero apresenta ora o plano divino, ora o humano, o mesmo fazem os romancistas, ao dar conta do que acontece com o jovem herói e com a heroína no momento em que estão separados e vagando pelo mundo (Hägg, 1983, p.110). Além disso, antecipações são, como na épica, frequentes, por meio de oráculos, presságios e sonhos. ${ }^{49}$

Curiosamente, Heliodoro é o único dos autores que conhecemos a se valer do expediente de começar a narrativa in medias res e de construí-la de modo não linear, prestando uma homenagem a Homero ao fazer seu leitor se deparar logo de início com uma cena devastadora de destruição e morte, apresentada pela perspectiva de bandidos que a observam com olhos atônitos. Lentamente são desvendados os motivos que levaram o casal de heróis, Teágenes e Caricleia, ao local em que momentos antes havia ocorrido uma luta armada que deixara várias vítimas; é necessário seguir até quase metade da extensa narrativa, que ocupa três volumes na edição da Belles-Lettres.

A viagem de Odisseu e a relação com sua esposa Penélope são dois elementos que frequentemente permitem alusões aos poemas homéricos nos romances. Penélope e Helena são, naturalmente, dois modelos femininos principais das heroínas e ora os romancistas as aproximam de uma, ora de outra, caso se queira enfatizar sua prudência e castidade ou o poder de sua beleza. Além disso, como nota Morales (2005a, p.7), “ $a$ representação dessas heroínas como Helena faz do adultério uma possibilidade sempre presente, apesar das conhecidas e às vezes obsessivas juras de castidade e fidelidade”. A história criada por Cáriton, por exemplo, foi considerada herdeira direta de Homero por conta do problema inicial criado pelo autor: Calírroe, casada no começo da história com o seu verdadeiro amor, o siracusano Quéreas, acaba por arranjar um segundo e honrado marido, Dionísio, na Jônia, para onde o primeiro viaja com intenção de recuperá-la. ${ }^{50} \mathrm{O}$ plano inicial reproduz o motivo da Guerra de Troia e, ao descrever Calírroe adentrando o tribunal na Babilônia (V.5.9) onde encontrará os dois maridos, o

\footnotetext{
${ }^{49}$ Cf. Bartsch (1989).

${ }^{50}$ Essa hipótese foi recentemente criticada por Tilg (2011), mas acho pouco provável que o Cáriton não esteja trabalhando com a hipótese do leitor identificar Calírroe com Helena.
} 
narrador cita ora um trecho da Ilíada no qual será descrita a reação dos troianos mais velhos diante de Helena, ora um da Odisseia, dessa vez referente à atitude dos pretendentes ao ver Penélope (Ilíada, III.146 e Odisseia i.366 = xviii.213). Se, nos romances, a mulher não permanece em casa à espera do marido e também ela se envolve em viagens e aventuras, por outro lado, a sua fidelidade é frequentemente posta à prova, a qual a heroína mantém não raro se valendo da sua astúcia, como Penélope controlando seus muito pretendentes. Xenofonte de Éfeso, por exemplo, faz sua heroína Ântia, que em determinado momento da narrativa vai parar em um bordel, ter a ideia de fingir uma crise da "doença sagrada" para afastar possíveis clientes (V.7).

Uma interessante passagem de Heliodoro (V.22.2-3) concentra várias alusões a Odisseia e nos permite ilustrar como o romancista explora a relação entre sua própria obra e a de Homero:

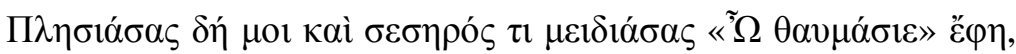

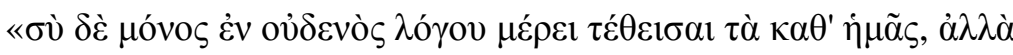

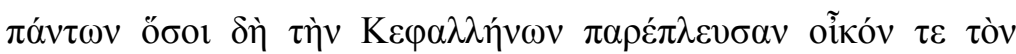

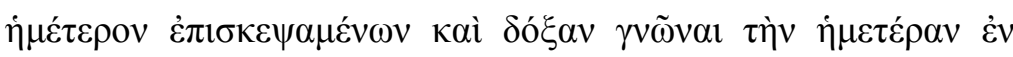

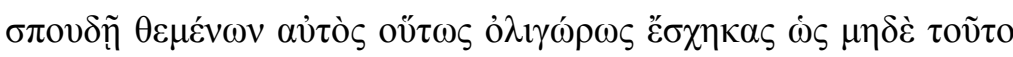

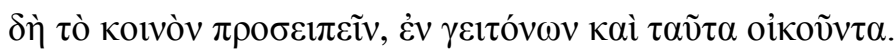

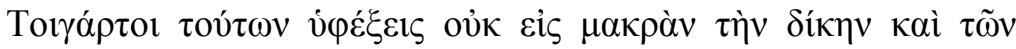

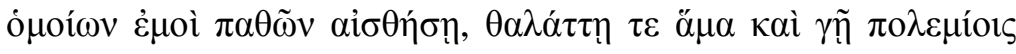

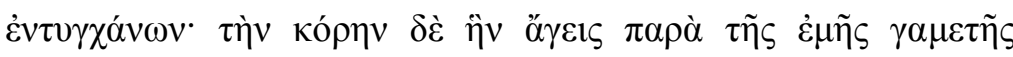

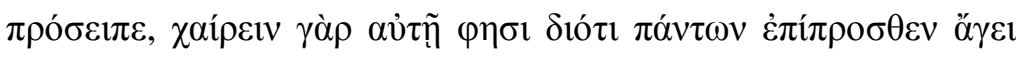

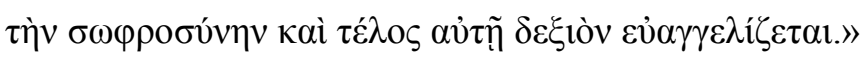

Aproximou-se de mim e falou com um meio sorriso: "admirável amigo, tu és o único a não fazer nenhum caso de nós, pois todos aqueles que navegaram ao longo de Cefalônia visitaram nosso lar e consideraram algo estimável conhecer minha glória. Tu te mostras negligente a ponto de não fazer uma simples saudação a mim, que, além disso, embora minha morada fique nas vizinhanças. Muito bem, não será barato o preço que pagarás por isso e terás que aprender pelas mesmas dores que eu, encontrando inimigos tanto no mar quanto na terra. Mas a moça que conduzes saúda da parte da minha esposa, pois ela lhe diz que se alegre por 
colocar a castidade diante de tudo e anuncia-lhe que terá um final feliz".

Calasíris, um velho sacerdote egípcio, é quem relata o sonho, e em outro momento do romance (III.14-15) afirma ser um intérprete dos poemas de Homero e diz que o poeta teria sido ele próprio egípcio (da cidade de Tebas) e, portanto, um conterrâneo seu, filho do deus Hermes. O sonho de Calasíris com Odisseu ressalta o fato de o personagem se relacionar com o herói pelo motivo do exílio, e por ser ele mesmo um segundo narrador no interior da narrativa. Seu relato do que havia acontecido antes do momento em que o romance tem início deixa claro ao leitor que Calasíris é ardiloso, sabendo se valer do engano e de disfarces, ${ }^{51}$ uma habilidade que ele ensinará a Caricleia. Na passagem citada podemos ainda ver o sonho funcionando como meio de antecipação, dando a conhecer ao leitor que a história terá final feliz. É justamente o fato de que tanto as narrativas romanescas quanto a odisseica convergem em direção a um objetivo que faz do poema homérico "fons e origo”, nas palavras de Reardon (1991, p.5), do romance, no qual os heróis são levados a enfrentar vários obstáculos para obter o que desejam. A figura de Odisseu como modelo de perseverança na longa jornada até o retorno à Ítaca é associada ao casal de protagonistas na sua trajetória quase sempre circular no interior da narrativa. Como observa Lalanne (2006, p.128), Odisseu é o preferido dos romancistas porque "o herói que eles louvam não é guerreiro nem caçador, mas aquele que volta para casa no dia seguinte à batalha”.

Para a caracterização da heroína do romance, apontou-se também a influência de Apolônio de Rodes, uma vez que o poema helenístico Jasão e os Argonautas seria mais próximo do romance do que a épica homérica, pela presença do elemento erótico. Nesse sentido a principal contribuição de Apolônio teria sido a representação de Medeia, uma "jovem mulher burguesa apaixonada" (Ruiz-Montero, 1996, p.56). A épica helenística de Apolônio, além disso, conjuga temas essenciais às narrativas romanescas, o amor, a viagem e a aventura; e a caracterização do herói, Jasão, que problematiza os valores do código heroico, sinaliza a possibilidade de um novo modelo de heroicidade. ${ }^{52}$

O segundo gênero do qual os romancistas são mais claramente devedores é a historiografia. No entanto, a relação verdade-ficção é, nesse período, uma via de mão-

\footnotetext{
${ }^{51}$ Cf. J. Winkler (1999, original de 1982), Pinheiro (1991).

${ }^{52}$ Sobre o heroísmo de Jasão e a classificação de Beye (1969) do herói como "love-hero", cf. Rodrigues Jr. (2010).
} 
dupla: não só a ficção se apropria de elementos historiográficos, mas a historiografia pode se valer, em maior ou menor grau, com intuitos diversos, de elementos fictícios e adornos retóricos. ${ }^{53}$ Mais do que de Heródoto, Tucídides e Políbio, uma vertente da historiografia helenística teria se desenvolvido nos moldes de um autor como Ctésias de Cnido, historiador do final do século V a.C. tachado de mentiroso desde a Antiguidade, cuja História Persa e um relato de viagem à Índia são resumidos por Fócio (cod. 72). Hägg (1983, p.14) descreve bem o resumo da primeira obra ao afirmar que nela "os fatos históricos lutam uma batalha inglória com o desejo de chocar, comover, excitar e deslumbrar". Essa extensa obra, escrita em vinte e três livros, parece se inscrever no limite entre narrativa histórica e narrativa fictícia. Holzberg (2003, p.630) observa que um fragmento da História Persa de Ctésias (P.Oxy.2330) “contém o relato de um caso amoroso, e tanto os seus motivos quanto o estilo simples da obra de Ctésias possuem forte semelhança com o tipo de escrita que se encontra no romance grego". Para Holzberg, a abordagem de Ctésias ao seu tema pode indicar que o seu círculo de leitores fosse menos "culto" do que os leitores de, por exemplo, Tucídides, e que esse mesmo público poderia ter vindo a ser o dos primeiros romances gregos. A se julgar pela menção de Ctésias nas Histórias Verdadeiras de Luciano (I.3), porém, creio que não se pode considerar que o autor não fosse lido por um público educado, a despeito das críticas que sofresse.

Além de Xenofonte de Éfeso, outros dois romancistas conhecidos apenas pela Suda têm o mesmo nome, Xenofonte Cíprio e Xenofonte de Antioquia, possivelmente três pseudônimos inspirados em Xenofonte de Atenas. Essa provável relação é estabelecida principalmente em razão da Ciropédia, obra que guarda várias semelhanças com os primeiros romances, a ponto de ser às vezes também considerado um. ${ }^{54}$ De fato, o texto não é de classificação óbvia: "uma biografia de Ciro, o Grande, uma história do início do império persa, um romance, um encômio, um manual militar, um guia para

\footnotetext{
53 Para se ter uma ideia de como os historiadores que se contentavam em narrar apenas fatos verídicos eram artigo raro na Antiguidade, basta ler os exemplos de maus historiadores que escreveram sobre a Guerra dos Partos, elencados por Luciano em Como se Deve Escrever a História, embora seja necessário ponderar o tratamento cômico e, portanto, provavelmente distorcido que lhes é dado em uma obra na qual o autor se empenha em estabelecer os limites dos gêneros poético e historiográfico.

${ }^{54}$ Mais recentemente, cf. Zimmerman (2009).
} 
administração política de um império, uma obra didática sobre ética, moral e educação, etc. Ele é, de fato, todas essas coisas" (Gera, 1993, p.1). ${ }^{55}$

A Ciropédia relata a vida de Ciro, que reinou no século VI a.C., desde a infância passada na corte de Astíages, rei dos Medos, até sua chegada ao poder, descrevendo a trajetória de um líder político ideal. Não só a forma como é narrada a vida do monarca por Xenofonte antecipa a junção de prosa, ficção e ambientação histórica, mas também seu aspecto idealista será observado posteriormente nos romances de amor. ${ }^{56} \mathrm{Um}$ episódio em particular é sempre mencionado por seu caráter novelesco, o de Panteia e Abradatas. ${ }^{57}$ No entanto, se também na Ciropédia, como nos romances de amor, elementos históricos parecem constituir pouco além de pano de fundo contra o qual o narrador inscreve a história da vida de um personagem idealizado, um texto como o de Xenofonte distancia-se da prática romanesca do período imperial não pela ficcionalidade desta, já que a ficção é um elemento em comum, mas pela centralidade dos propósitos didático e paradigmático da obra. Isso, contudo, como observa Reichel (1995, p.3), "não exclui a noção de que a Ciropédia também contém uma quantidade considerável de boas histórias. Xenofonte de fato sabia como apresentar seu propósito didático incluindo seções divertidas e engraçadas em sua obra”. Nesse sentido, se o episódio de Panteia e Abradatas aproxima a Ciropédia do romance, sua posição marginal no interior da narrativa de Xenofonte os distancia. Como bem nota Tatum (1994), o aspecto moralizante da obra de Xenofonte faz com que esse episódio erótico ensine uma lição sobre os perigos de sucumbir ao amor e demonstre a exemplaridade do

\footnotetext{
${ }^{55} \mathrm{Eu}$ me pergunto o que mais poderia conter o "etc". A Ciropédia foi objeto de análise de outros três livros recentes, além do de Gera: Tatum (1989); B. Due (1989) e Nadon (2001).

${ }^{56}$ Reichel (1995) faz um estudo dos paralelos mais evidentes entre a Ciropédia e os romances de amor e discute a reflexão sobre a utilidade do pseudos feita no interior do próprio texto. Cf. Stadter (1991).

${ }^{57}$ Trata-se de uma história de amor trágica. Abradatas, rei de Susa, é feito prisioneiro de Ciro durante sua campanha contra os assírios. Ciro deixa seu amigo Araspas encarregado de cuidar da esposa de Abradatas, mas ele se apaixona por ela. Panteia, como uma boa heroína de romance, é chamada de a mulher mais bonita da Ásia e vê sua beleza ser causa de investidas indesejadas. Ela repele as tentativas de aproximação de Araspas e permanece fiel ao seu marido, enviado em uma missão pelo rei assírio. Quando a situação com Araspas chega ao ponto de se tornar violenta, Panteia pede ajuda a Ciro, que então envia seu subordinado em uma missão para afastá-lo dela. Agradecida pela atitude do rei, ela escreve ao marido contando o ocorrido e Abradatas, comovido, decide se tornar aliado de Ciro. Em uma batalha contra os egípcios, porém, ele acaba morto lutando pelo rei da Pérsia e Panteia reprova a si mesma por tê-lo exortado a lutar; Ciro tenta consolá-la, mas ela se mata sobre o corpo do marido.
} 
caráter de Ciro, que logo de início evita ser tentado pela beleza de Panteia, recusando-se a encontrá-la. ${ }^{58}$

Temos em Ctésias e Xenofonte dois exemplos de autores que inserem elementos fictícios em narrativas prosaicas, antecipando uma combinação de elementos observada nos romances, cujo ponto mais interessante, porém, é o uso deliberado de certa pose historiográfica do narrador romanesco para construir um efeito de plausibilidade. A intenção de criar uma história plausível, que dê ao leitor a sensação de "isso poderia ter acontecido", implica que os personagens se movam em um mundo próximo do conhecido pelo leitor (pela experiência ou pela leitura) e também que os romancistas empreguem elementos reconhecíveis como próprios do gênero que lida principalmente com fatos verídicos. Um caso importante no que diz respeito aos temas tratados nos romances é a reprodução de uma tensão entre civilização grega e o mundo bárbaro, observável em todos os romancistas com exceção de Longo. Já um exemplo de técnica narrativa tomada da historiografia é vista quando o narrador de Heliodoro expressa dúvida sobre o que é relatado. Ora, se a dúvida diz respeito a fatos reais, ela bem pode ser uma dúvida real do autor, mas quando essa expressão se refere a fatos inventados pelo próprio romancista, o que temos é um narrador adotando uma postura de historiador. $^{59}$

Em Cáriton de Afrodísias, o uso de elementos historiográficos é bastante saliente, menos por estratégias narrativas, como é o caso de Heliodoro, e mais pela ambientação. O próprio início do romance evoca os proêmios dos historiadores: " $E u$, Cáriton de Afrodísias, secretário do retor Atenágoras, narrarei uma paixão erótica acontecida em Siracusa". ${ }^{60}$ A obra de Cáriton apresenta aspectos de um romance histórico, ainda que a rigor não possamos chamá-lo dessa forma, uma vez que a acuidade na representação do período clássico não é objetivo do autor; na verdade, ele dá ao seu romance um "colorido histórico", com alusões que os leitores poderiam reconhecer na tradição historiográfica grega. No entanto, o romance, de fato, como apontou Hägg (1987), apresenta aspectos característicos do subgênero. Cáriton narra

\footnotetext{
58 "It is an authoritarian, patriarchal denial, not of the possibility of erotic fiction - as we can see from Araspas and Cyrus, Xenophon knows how to assemble a conventional love story - but of it desirability. He wants something else". (Tatum, 1994, p.21).

${ }^{59}$ Cf. J. Morgan (1982 e 1993).

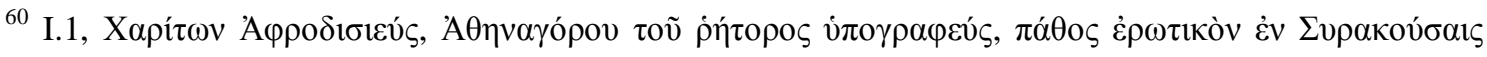

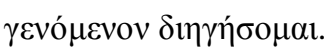


acontecimentos que datariam do século IV a.C., ainda que a construção dessa realidade histórica seja pontuada de anacronismos. Parte de seus personagens é facilmente identificável em registros históricos: o pai da heroína, Calírroe, é Hermócrates de Siracusa, famoso líder que derrotou a expedição ateniense em 415 a.C., fato a que o narrador alude ao longo da história com frequência. O Grande Rei é identificado com Artaxerxes II, que governou a Pérsia entre os anos de 404-358 a.C. ${ }^{61}$ Essa forte relação com a historiografia em Cáriton seria justificada pelo fato desse "verniz" ter tido, nos primeiros romances, uma função importante para a recepção adequada do gênero. O que se buscava era a chamada "crença ficcional" do leitor, em que a suspensão dos critérios de verdade é necessária para a recepção bem-sucedida do texto, algo que era construído a partir de um conhecimento da tradição literária grega compartilhado pelo autor e seus leitores.

Além da épica e da historiografia, elementos de outros gêneros são observáveis na configuração do romance, que menciono brevemente. As referências à tragédia, por exemplo, são frequentes, e os romancistas gostam de utilizar metáforas teatrais para chamar a atenção para cenas de forte acento patético. Apenas para exemplificar um recurso comum, veja-se como Heliodoro coloca as palavras irônicas de um personagem em nível metaliterário. Trata-se do momento em que Caricleia, perto de se tornar uma vítima sacrificial, tenta anunciar sua real identidade para os pais, rei e rainha da Etiópia. Hidaspes, sem acreditar no que ela diz, afirma que Caricleia "finge ser minha filha, como se no palco, em uma situação sem saída, surgisse ex machina”. ${ }^{62}$ Cáriton chega mesmo a afirmar, talvez dando uma interpretação equivocada ao termo aristotélico, que o seu último livro purificará tristes eventos dos livros passados ${ }^{63}$ e os lamentos dos personagens são às vezes introduzidos pelo verbo $\tau \rho \alpha \gamma \omega \delta \varepsilon \tilde{\imath}{ }^{64}$

Fusillo (1991, p.35), porém, vê nessas referências apenas comentários metaliterários, percebendo como contribuição principal da tragédia à criação do

\footnotetext{
${ }^{61}$ Um dos anacronismos de Cáriton: Hermócrates teria morrido no ano de 408 a.C., antes de Artaxerxes II subir ao poder.

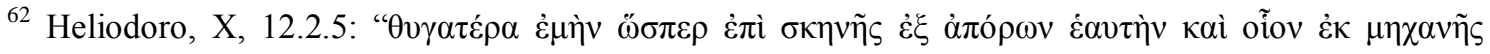

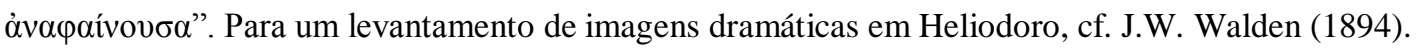

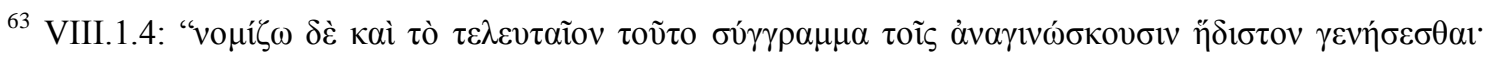

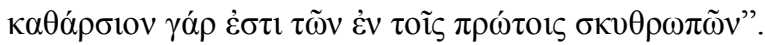

${ }^{64}$ Por exemplo, Aquiles Tácio VI.4.4, VIII.1.5; Heliodoro, I.3.2.
} 
romance a presença de monólogos deliberativos, ${ }^{65}$ sobretudo da parte das heroínas. Tais monólogos, que analisam um conflito psicológico, teriam como paradigma ilustre o da Medeia de Eurípedes. O tragediógrafo, aliás, é peça importante da tradição literária que vai culminar no romance; sua Helena na peça homônima não só é dona de uma beleza que lhe traz muitos problemas, mas também casta e fiel e, por outro lado, inteligente e ativa, como seriam as futuras heroínas dos romances. E mesmo o motivo da separação e do reencontro dos amantes, com o deslocamento de ambas as partes, também se faz presente na peça.

A plausibilidade, por sua vez, é um critério que aproxima os romances da comédia nova e recentemente Lowe (2000) argumentou que podemos considerar que o romance transpõe o gênero para a forma narrativa do mesmo modo que a tragédia pode ser considerada uma reescrita da épica (idem, p.239). ${ }^{66}$ A forma como os comediógrafos lidam com o elemento amoroso fornece um antecedente fundamental para o romance, já que também faz parte das convenções estabelecidas por Menandro, além do reconhecimento quando adultas de crianças expostas (como vemos em Longo e em Heliodoro), o amor à primeira vista de um rapaz por uma jovem em uma trama que se encerra com casamento. Ainda que remontem a práticas anteriores, sobretudo à tragédia de Eurípides, os pontos de contato principais entre romance e comédia são o enfoque na vida privada e a importância dada a Týche no desenrolar dos infortúnios do casal protagonista, que fica à mercê do destino independentemente dos seus desejos e intenções. Além disso, a figura do servo fiel e ardiloso é observável em Aquiles Tácio no personagem de Sátiro e na Plângon de Cáriton; Gnathon, em Dáfnis e Cloé, cujo próprio nome já revela uma influência cômica, é claramente um parasita.

\footnotetext{
${ }^{65}$ Por exemplo, Quéreas e Calírroe, II, 9.2-6.

${ }^{66}$ O mesmo já havia sido defendido também por Fusillo (1991, p.51): “todos os romances gregos retomam o mesmo esquema narrativo de Menandro". Lowe (2000, p.225): “The universal narrative goal in the love-novels is secure possession of the beloved. Generically, this requires fulfilment of four conditions, all drawn from New Comedy: (i) legal citizen marriage, sanctioned (as in comedy) by the surviving heads of both families; (ii) permanent residence in the home community; (iii) freedom from erotic competition; (iv) preservation of the exclusive reproductive bond".
} 


\section{I.2.2 Guerra e Violência}

Ainda que constitua um aspecto central do gênero, não é o uso da prosa para veicular ficção que distingue os textos que formam o corpus a ser analisado nesta tese das demais práticas literárias antigas. São, como já se afirmou, as convenções do enredo, facilmente reconhecíveis, que motivam a reunião dessas cinco obras sob uma mesma classificação genérica. Com frequência se afirma que os temas principais do romance grego são o amor e a aventura, mas nos parece claro que é necessário incluir nessa fórmula também a violência, uma característica distintiva do gênero.

À guisa de exemplo, podemos observar que se a viagem é a situação que em geral propicia os episódios de violência nos romances de amor, nas Histórias Verdadeiras de Luciano de Samósata e em As Maravilhas de Além-Tule de Antônio Diógenes, as aventuras decorrentes da viagem têm outro caráter. Ainda que haja episódios bélicos no texto de Luciano e ação violenta da parte de alguns povos hostis que o narrador e seus companheiros encontram, esse não é um elemento preponderante na narrativa, que se desenrola como uma viagem de exploração. Além disso, a ausência de caracterização psicológica dos personagens e o forte tom humorístico do texto - que envolve a paródia do heroísmo de Odisseu - resultam na impossibilidade de perceber os viajantes como vítimas de atos de violência ou, por outro lado, grandes heróis de guerra. Por sua vez, como só conhecemos As Maravilhas de Além-Tule pelo resumo de Fócio, não é possível afirmar com certeza qual a importância que a representação da violência possuía na narrativa original. Fócio certamente menciona algumas situações que configuram episódios violentos, mas talvez pelas características do texto de Antônio Diógenes, talvez pelos episódios que o patriarca escolhe mencionar, as aventuras, como o próprio título da obra já indica, são menos violentas do que fantásticas. Um exemplo é o tratamento dado ao motivo do Scheintod, a morte aparente, que se nos romances de amor é em geral resultante de um falso assassinato, em As Coisas Incríveis de AlémTule é, em duas situações distintas, provocado pela ação malévola de um feiticeiro, que ora faz dois irmãos morrerem durante o dia e ressuscitarem à noite, ora faz seus pais caírem em um longo sono semelhante à morte.

Embora no caso particular de Dáfnis e Cloé não haja viagem, em geral é o distanciamento da Grécia que permite que o casal seja envolvido em situações perigosas. A violência perpassa os romances em diversas formas: em todos ocorre contato entre os jovens heróis e piratas ou bandoleiros violentos que os raptam quase 
sempre com intenção de vendê-los. Muitas vezes, essa situação envolve ameaça de agressão sexual, uma vez que a beleza dos heróis e das heroínas faz com que muitos se apaixonem por eles e nem sempre os pretendentes estão dispostos a tolerar uma rejeição inicial. Às vezes as heroínas matam seus agressores, como é o caso de Ântia (IV.5) ou de Caricleia (V.32). Há situações em que, escravizados ou deslocados da posição social que ostentam no início da narrativa, os amantes sofrem tratamentos injustos em países estrangeiros, sendo forçados a trabalhar e às vezes até presos por crimes que não cometeram, com ameaça de serem torturados ou punidos com a morte. Em algumas das histórias, o narrador trabalha também com as expectativas dos leitores ao inserir episódios de morte aparente das heroínas, quase sempre, como já se afirmou, resultante de um ato violento, do qual o exemplo máximo é Leucipe, que uma vez é sacrificada e estripada por bandidos egípcios (III.15), os quais em seguida comem suas entranhas, e depois é degolada por piratas (V.7). Ântia também é quase sacrificada ao deus Ares pelo bando que a havia capturado, cuja maneira comum de realizar o sacrifício era pendurar a vítima em uma árvore e atirar dardos contra ela (II.13) - e depois a heroína ainda é deixada com dois cães esfomeados em um buraco (IV.6) como punição por ter matado o bandido que tentara violentá-la. ${ }^{67}$

Habrocomes, de As Efesíacas, é possivelmente o herói que mais sofre em suas andanças pelo Mediterrâneo. Acusado falsamente por Manto de tê-la violentado, seu pai Apsirto (que o escravizava) ordena que ele seja espancado e torturado com fogo (II.VI) e depois levado à prisão. No Egito, acusado de novo falsamente, dessa vez por Cino, de ter matado o seu marido, ele é mais uma vez preso por um crime que não cometeu e é levado à crucificação e, em seguida, à pira (IV.2), mas é salvo nas duas situações graças a suas preces. Na Sicília, ele é ainda obrigado a se empregar em uma pedreira: “o trabalho lhe era penoso, pois seu corpo não estava acostumado nem havia se submetido

\footnotetext{
${ }^{67}$ Nos fragmentos de romance conhecidos, a violência parece ser recurso ainda mais frequente. Em $A s$ Babilônicas, de Iâmblico, por exemplo, conhecido pelo resumo de Fócio (cod.94), os heróis Sinônis e Rodanes tem de enfrentar ao longo da narrativa a perseguição do rei da Babilônia, que deseja desposar a heroína. Quem empreende a perseguição na maior parte da história são dois eunucos, Damas e Sacas, que têm orelhas e narizes cortados no início da história como punição por deixarem os amantes escaparem. Da série de aventuras que Sinônis e Rodanes enfrentam, um caso curioso é o Scheintod da heroína, que ocorre quando seu pai vê o cão de Rodanes comendo dois corpos, um dos quais ele presume ser de sua filha. Ele enterra, então, o que resta do cadáver sob os dizeres "aqui jaz a bela Sinônis", fazendo com que Rodanes acredite na sua morte.
} 


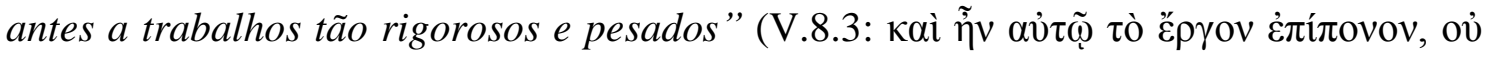

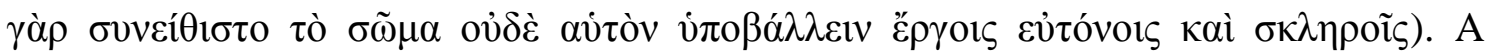
violência é mantida de modo proporcional contra a heroína do romance, pois Ântia, além de sofrer na mão de bandidos, é aquela que mais têm de enfrentar pretendentes indesejados e violentos. ${ }^{68}$

Por que há tanta violência no romance? Em geral, se tentou responder essa questão analisando aquela violência praticada contra as heroínas. Winkler (1990) em sua bela análise sobre Dáfnis e Cloé sugeriu uma leitura (reconhecida por ele como anacrônica) de um processo de aprendizagem da heroína a respeito da violenta dominação masculina em uma sociedade patriarcal. Chew (2003) observa que essa violência é predominantemente sexual (mesmo de forma metafórica) ${ }^{69}$ pela importância dada à castidade feminina nas relações sociais. Uma vez que "as mulheres na Antiguidade eram responsáveis pela manutenção de suas famílias e, de modo geral, também da sociedade", a perda da virgindade ou da castidade representaria uma ameaça à estabilidade social. O estudo de Morales (2005a, p.152-219) sobre visão e narrativa em Aquiles Tácio demonstra que Leucipe sofre violências metafóricas sucessivas no romance, começando pelo fato de que ela é descrita como um banquete para os olhos de Clitofonte (I.6.1-2), e que essa violência continua presente nas écfraseis, como na descrição de Andrômeda (III.7) e da violação de Filomela por Proteu (V.3), que chamariam a atenção para a sexualidade masculina agressiva da qual a mulher é vítima. ${ }^{70} \mathrm{O}$ narrador Clifotonte utiliza um vocabulário de violência quando descreve a observação de Leucipe por homens que a desejam, incluindo ele próprio (idem, p.158), algo que é indício de que a beleza feminina, embora tenha um efeito sobre os homens,

\footnotetext{
${ }^{68}$ Os pretendentes vão se tornando cada vez mais violentos ao longo da narrativa, ao ponto de Psammis, Anquíalo e Poliido tentarem violentá-la (III.11.4; IV.5.5 e V.4.5) e Ântia acabar em um bordel onde muitos homens a desejam (V.7.3).

${ }^{69}$ Em Etiópicas, por exemplo, quando Tíamis interpreta o seu sonho e imagina que golpear Caricleia com uma espada significa desvirginá-la (I.18) e depois acredita que a imagem que aparecera em seu sonho era literal e ele tenta assassiná-la (I.31).

${ }^{70}$ Morales (2005a, p.183) observa que são duas funções contraditórias que justificam o uso de écfraseis e visões para a representação da violência no romance de Aquiles Tácio: trata-se, primeiramente, de uma estratégia de distanciamento, para afastar o leitor de uma resposta emocional e empática ao objeto, de modo que ele é "tirado do mundo real". Por outro lado, por estarem destacadas da narrativa, essas passagens chamam a atenção e demandam interpretação. Sobre a linguagem de violência empregada nos romances, cf. também Morales (2005b).
} 
não é sinônimo de poder, pois a heroína não pode controlar esse efeito e é vítima de olhares e abordagens indesejadas.

Lalanne (2006, p.255-274), por sua vez, percebe três aspectos principais da violência praticada contra as mulheres nos romances e faz, como Morales, uma leitura feminista do gênero. Ao analisar os diversos momentos da narrativa em que Leucipe é vítima e as imagens são descritas com pormenor por seu amado Clitofonte, narrador dos eventos, a crítica francesa nota um prazer pornográfico da leitura: trata-se de uma "excitação erótica produzida pelo o espetáculo dos constrangimentos físicos e psíquicos exercidos sobre as mulheres pela sociedade falocrática" (idem, p.255). ${ }^{71}$ Por outro lado, a violência doméstica seria representada como algo natural com o qual a mulher deve se acostumar para assumir o seu papel de esposa, algo que se refletiria no fato de que a perda da virgindade da mulher é representada, em geral, como um ato violento, e também no pontapé que Quéreas dá em Calírroe, quase provocando sua morte. Por fim, Lalanne conclui que essa ameaça de violência sexual presente com tanta frequência é um rito de passagem importante nas práticas simbólicas que ela percebe ser desenvolvidas no enredo dos romances (idem, p.274):

\begin{abstract}
Se um rito de passagem tem como objetivo formar a jovem para uma nova posição social e, portanto, de educá-la em função de normas culturais previamente definidas, e se a violência necessária a realizar esse rito de passagem é proporcional à resistência encontrada, a severidade das provas infligidas às heroínas é sinal de uma força extremamente coercitiva da sociedade na qual elas evoluem. [...] A violência que se manifesta à ocasião da aprendizagem de seu papel na sociedade diz respeito à distância observada entre norma social e a natureza.
\end{abstract}

Lalanne (idem, p.277) defende também que a desproporção entre a violência sofrida entre homens e por mulheres reflete o "nível de coerção necessário" para moldar os papéis sociais de um e de outro, do qual resultaria o fato de que as heroínas são reduzidas a uma "função social sem identidade", ao passo que a masculinidade representada no romance é "artificial e arcaizante".

\footnotetext{
71 Anderson é o primeiro a mencionar Clitofonte como um narrador "voyeur" (1982, p.24), ideia posteriormente desenvolvida por Konstan (1994, p.60-72).
} 
Pouco, porém, se discutiu a violência como algo que diz respeito à formação do herói no romance, em que às vezes ela é representada como atitude adequada, mas outras vezes algo de que eles devem refrear. Isso está de acordo com uma concepção tradicional da masculinidade como observada, por exemplo, na Atenas no período clássico por Fischer, onde uma atitude violenta era esperada como capacidade de responder de modo apropriado a insultos (1998, p.70). Nem sempre, porém, os heróis romanescos demonstram ter essa capacidade ao ser agredidos, algo que talvez deva ser aprendido em sua jornada pelo Mediterrâneo. Ao mesmo tempo, podemos observar nos romances homens da elite grega praticando atos violentos nem sempre justificáveis, como o bandido Hipothoo, ${ }^{72}$ de Xenofonte de Éfeso; afinal, ainda que se tenha que considerar seu deslocamento da sociedade a que de início pertencia, também o herói Habrocomes perde sua respeitável posição social quando deixa Éfeso e, mesmo viajando ao lado de Hipothoo, nunca abraça a vida de bandido. Outro exemplo são jovens metimnenses que vão se divertir no campo em Dáfnis e Cloé e terminam se comportando como verdadeiros piratas.

Como contrapartida, parece ter sido desde o início parte importante da constituição do romance que a violência se apresentasse na sua faceta organizada, controlada e pública, ou seja, na guerra, em que atos violentos não só são admitidos como conferem renome àquele que os pratica. Mesmo em Xenofonte de Éfeso é possível discernir certo tratamento dado ao tema quando se relata duas tentativas do estado de controlar a ação dos bandos liderados por Hipothoo. A primeira delas tem uma função bastante clara na narrativa, que é a de salvar Ântia de ser sacrificada por bandidos e de dar a ela um novo pretendente indesejado na figura de Perilau (II.13). A destreza de Hipothoo é ressaltada, pois ele é o único a conseguir escapar e, quando ele chega com Habrocomes à Capadócia, logo forma um novo bando (III.1), com o qual põe em prática planos mais ambiciosos: "pois não contentava a Hipothoo roubar

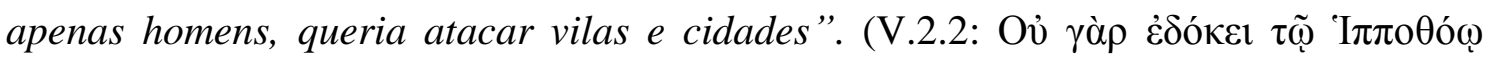

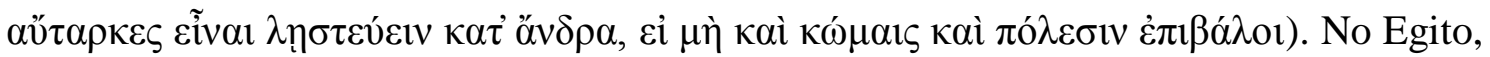
o bando ataca a aldeia de Aria (V.2), matando vários dos seus habitantes e pondo fogo às casas e, na fuga, rouba vários barcos de aldeias à beira do Nilo. Essa "escalada de violência" de Hipothoo parece ser o passo necessário para encerrar de vez sua carreira na bandidagem e obrigá-lo ao retorno à sociedade, pois, na sequência (V.3-5), o

\footnotetext{
${ }^{72}$ Sobre o personagem, cf. Watanabe (2003) e Alvares (1995).
} 
governador do Egito designa Poliido para assumir a frente de um número considerável de soldados com a missão de livrar o país dos bandoleiros. Mais uma vez, Hipothoo é o único do seu grupo a se safar. Não há propriamente o desenvolvimento de um episódio de guerra, uma vez que a narrativa logo é desviada da ação de Poliido como general para sua paixão por Ântia, que ele tenta violentar e que depois sofrerá novas adversidades provocadas pela sua esposa enciumada.

Em trabalho recente, Hornblower (2007) discute o fascínio da literatura grega com o tema da guerra em termos de um paradoxo, uma vez que a sociedade grega não seria militarista ${ }^{73}$ nem, ao contrário do que frequentemente se supõe, veria a guerra como um estado natural, existindo na verdade diversas evidências não literárias de uma série de meios institucionalizados para evitar o conflito armado. Entre as seis sugestões que podem resolver o problema, o crítico afirma que a representação da guerra de uma forma idealizada, que deixava de lado combates muito mais comuns que tinham proporções menores que uma batalha, servia à preservação de (idem, p.50) "uma ideologia essencialmente masculina, na qual reconhecidamente a excelência masculina é definida pela capacidade de proteger as mulheres". Hornblower em outra passagem (idem, p.46), para demonstrar que disputas por causa de mulheres são importantes desde o início da tradição da escrita da guerra, sendo até mesmo em Tucídides motivo para iniciar um conflito, chama a atenção para um trecho (VI.6.2) em que o historiador afirma que duas comunidades na Sicília, Selino e Egesta, haviam entrado em guerra

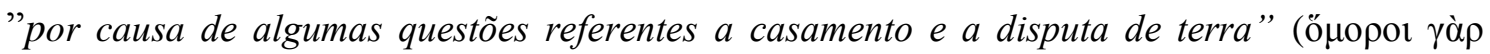

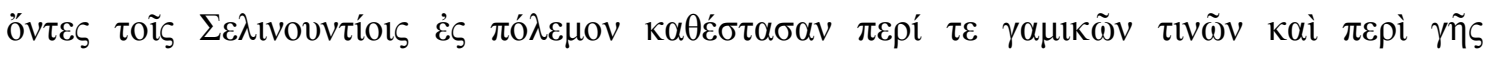
$\dot{\alpha} \mu \varphi \iota \sigma \beta \eta \tau \dot{\tau} \tau o v) "$

\begin{abstract}
"gamika" é normalmente traduzido como 'direitos de casamento', mas 'direitos' é algo estreito demais; a palavra também diz respeito à propostas rejeitadas, acordos desfeitos, e todo esse tipo de coisa, sobre as quais sociedades guiadas por um sentido mediterrâneo sensível de honra poderiam se inflamar.
\end{abstract}

\footnotetext{
73 Idem, p.27: 'I define a 'militaristic' society as one geared virtually exclusively for war, one whose male citizens enjoy war for its own sake and in which the behaviour of its women mirrors that enjoyment, and in which preoccupation with war overshadows most else”.
} 
Esse não é sempre, porém, como se talvez pudesse esperar, o motivo que leva à guerra nos romances. Como já se afirmou, com frequência a conjugação de amor e guerra no gênero foi justificada pela intenção dos escritores de aproximá-lo da historiografia, ${ }^{74}$ tendo em vista a necessidade, por um lado, de garantir a crença ficcional do leitor ${ }^{75} \mathrm{e}$, de outro, de dar certo verniz a uma forma literária recém-criada. ${ }^{76}$ De fato, textos que mantêm uma relação mais próxima com a historiografia, como é o caso do romance de Cáriton, parecem apresentar o herói romanesco como líder militar, pois parte importante dos fragmentos de Nino, datados de cerca de 100 d.C., centra-se na primeira campanha militar do rei assírio Nino. Um fragmento de Sesoncôsis, por sua vez, no qual o personagem principal é um monarca egípcio, possui várias semelhanças estruturais com Nino: "ambos incluem acontecimentos do período em que o jovem príncipe está amadurecendo; uma primeira aventura militar - Nino contra os armênios, Sesoncôsis contra os árabes - e um compromisso com uma moça descrita como

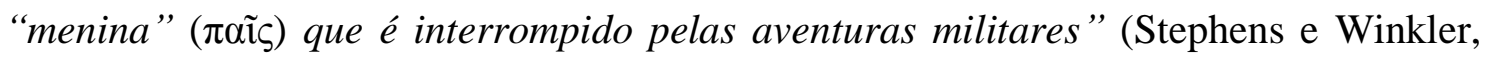
1993, p.248). Segundo o resumo de Fócio (cod.94), em As Babilônicas, a reunião do casal ocorre no fim da narrativa por meio de um episódio bélico, quando o rei da Babilônia entra em guerra contra o rei da Síria, que estava prestes a se casar com Sinônis. Rodanes lidera o exército e acaba por reencontrar a heroína e conquistar o governo da Babilônia. Não por acaso, todos os fragmentos mencionados são colocados por Stephens (1996) na categoria de "romances nacionais", que em geral tratam das aventuras de juventude de personagens históricos ou lendários não gregos, ainda que os seus modos sejam representados como aqueles da elite grega do período imperial. Infelizmente, não temos como saber como a guerra era desenvolvida por esses romancistas apenas por meio dos fragmentos.

É claro, porém, que em Cáriton de Afrodísias a guerra é o meio pelo qual se de pode dar ao protagonista masculino um verniz heroico, estabelecendo-o como capaz de

\footnotetext{
${ }^{74}$ Recentemente, Tilg (2010, p.26) propôs que a conjunção dos temas amor e guerra faz sentido em uma Afrodísias onde Afrodite era considerada, como a mesopotâmica Ishtar, a deusa não só do amor como da guerra: "This role of the Aphrodite of Aphrodisias is likely to have remained vital for the best part of the first century $b c$, during which Aphrodisian identity was largely formed by military achievements as an ally of Rome. It strikes me that the two elements, love and war, also inform the structure of Chariton's novel".

${ }^{75}$ Cf. Morgan (1982 e 1993).

${ }^{76}$ Cf. Fusillo (1991, especialmente p.61-65).
} 
proteger Calírroe (e, por conseguinte, a cidade de Siracusa), uma vez que não se trata de um personagem histórico (como nos fragmentos acima citados), cujas atividades militares pudessem explicar a inserção do tema numa narrativa de amor. Essa (possível primeira) função da guerra no romance, porém, não é repetida em nenhum dos outros exemplares que possuímos e uma leitura mais atenta de Quéreas e Calírroe nos mostra uma segunda função do episódio bélico, que diz respeito à constituição de uma identidade masculina mais afinada com ideais sociais da época relacionado ao uso e ao controle da violência. Desse modo, embora às vezes sejam interpretadas como apenas mais uma das várias aventuras pelas quais os heróis têm de passar, as guerras narradas nos romances gregos são uma convenção que pode assumir funções mais sutis na narrativa. São elas que buscamos evidenciar nos capítulos seguintes desta tese. 


\section{Quéreas e Calírroe: ${ }^{1}$ Um Marido Ideal}

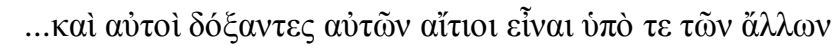

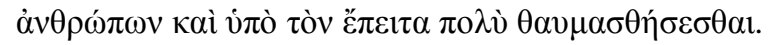

...E eles [os siracusanos], considerados os responsáveis por esses feitos, tornar-se-iam objeto de grande admiração tanto de seus contemporâneos quanto da posteridade.

Tucídides, VII.56.

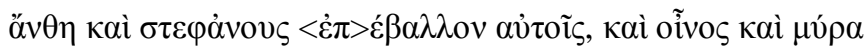

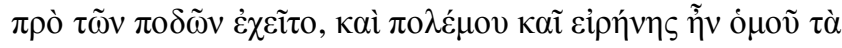

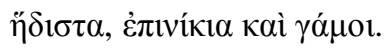

Atiravam-lhes flores e grinaldas, vinho e perfumes eram derramados aos seus pés, havia ao mesmo tempo os maiores prazeres da guerra e da paz, canções de vitória e de bodas.

Cáriton de Afrodísias, VIII.1.12-13 ${ }^{2}$

O trecho do romance de Cáriton de Afrodísias citado acima descreve a cena em que, logo no início do livro final da narrativa, fundem-se numa única celebração a vitória militar de Quéreas, que comandava um grupo de gregos mercenários em uma revolta egípcia contra o domínio persa, e o seu reencontro com a esposa Calírroe. São

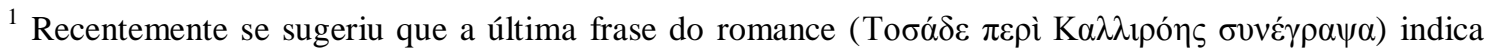
qual teria sido, de fato, seu título. Plepelit (1976 apud Reardon, 1999) lançou a hipótese de que o título tenha sido apenas "Calírroe”" (adotado por Goold em sua tradução do romance na coleção Loeb de 1995).

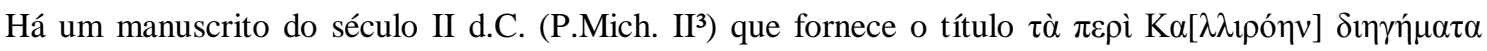
adotado por Reardon na sua edição da Teubner (2006). Tilg (2010) igualmente defende a opção Tà

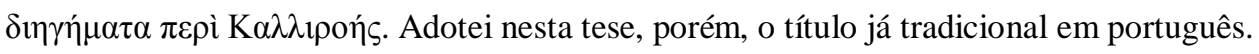

${ }^{2}$ O texto grego de Quéreas e Calírroe citado neste capítulo é o da edição de Reardon (2006) para a Teubner.
} 
essas as condições para que, finalmente, possam voltar à sua pátria e retomar seu casamento. Assim, não é por acaso que o narrador afirma, no início desse livro, que ele

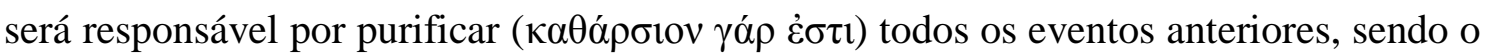

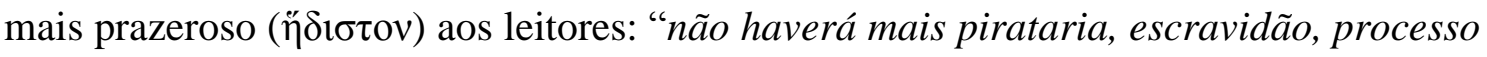
judicial, luta, suicídio, guerra e conquista, mas agora, sim, amores justos e casamentos legítimos". 3 Temos aí manifestos três elementos centrais na narrativa de Cáriton: as muitas desventuras dos amantes, o final feliz, e uma demonstração da consciência do narrador com relação ao seu processo diegético, que nesse trecho se revela principalmente por meio do termo que emprega para caracterizar seu último livro

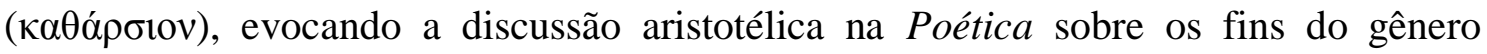
trágico.

Se Cáriton de Afrodísias é ou não o romancista pioneiro e se temos ou não a possibilidade de vislumbrar nas páginas de Quéreas e Calírroe uma reflexão sobre a criação de um novo gênero, como entende Tilg (2010), o fato é que sua narrativa é o exemplar íntegro mais antigo do romance de amor, considerando-se para ele um terminus post quem em 19 d.C. e um terminus ante quem em 62 d.C., ambos estabelecidos por Tilg, e foi produzida provavelmente poucas décadas antes de As Efesíacas, de Xenofonte de Éfeso. Mesmo que a hipótese do crítico se mostre razoável em sua argumentação, não se trata de, ao dar início à nossa análise pela obra de Cáriton, pensar o romance grego em uma diacronia que perceba nos exemplares íntegros que possuímos uma evolução qualitativa que atinge um maior grau de sofisticação com o romance sofístico de Heliodoro. Sequer existe a certeza de que narrativas mais sofisticadas não tenham sido produzidas no mesmo período que outras de estilo mais simples, havendo uma variação de registro que não coincide com um recorte diacrônico, mas que hoje não é mais evidente apenas por causa da quantidade restrita de textos que conhecemos na íntegra.

Como observa Reardon, porém, se não temos, de fato, evidências o bastante para afirmar categoricamente que a narrativa de Quéreas e Calírroe é o momento de nascimento do gênero, "temos, de fato, o suficiente para justificar o seu tratamento, de forma menos ambígua, como um ponto primordial de referência para o romance grego"

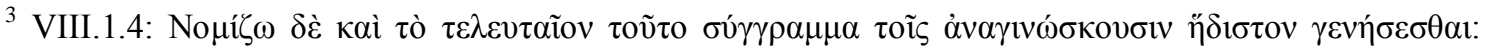

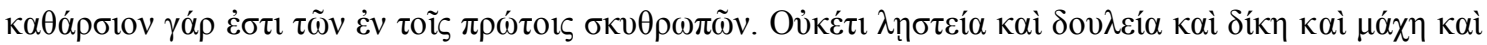

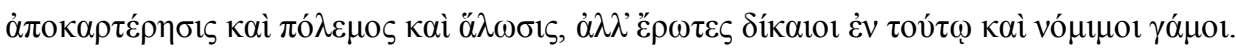


(1999, p.165). ${ }^{4}$ Uma perspectiva que perceba em Cáriton um possível estabelecimento da tópica romanesca e da estrutura do gênero apresenta, na nossa análise, a vantagem de permitir que se veja com maior clareza algo que por certo tempo se preferiu ignorar: a diversidade de tratamento e de função de temas convencionais mesmo dentro desse corpus restrito de romances atualmente conhecidos.

De qualquer modo, estivesse Cáriton criando uma nova forma literária, ou seguindo um modelo primordial hoje perdido, é visível que o autor criou o seu romance com o intuito de que ele fosse percebido em contraste com os gêneros canônicos. Vemos ao longo da narrativa diversas citações de Homero integradas à própria voz do narrador, ${ }^{5}$ em uma demonstração de erudição que o autor parece supor compartilhar com seus leitores. Os efeitos desse jogo de referências permitem refletir acerca do próprio status que o autor deseja dar à sua obra, inserindo o romance na tradição literária grega. Assim, Cáriton evoca também Tucídides e Heródoto nas frases inicial

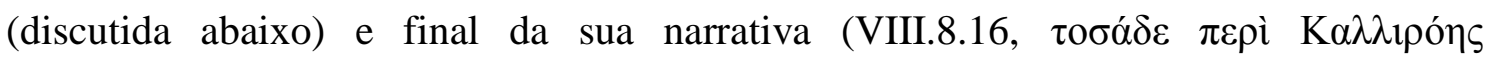

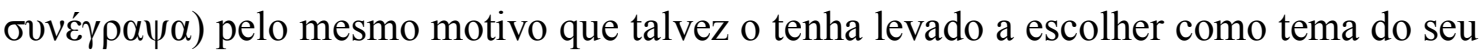
romance não qualquer história de amor, mas a que envolve o conhecimento de um importante episódio político da Grécia clássica: pode-se estar trabalhando em um novo gênero, mas se estabelece desde o início a paideia do autor. Cáriton, contudo, vai além ao explorar essa relação, valendo-se das alusões à tradição literária para também enfatizar o que é próprio do romance, em oposição a ela.

O breve prólogo do romance, aliás, parece a princípio preparar o leitor para uma narrativa de caráter historiográfico, mas que ao mesmo tempo declara como seu objeto um páthos erotikón, criando-se assim uma tensão entre um estilo que sugere o tratamento de grandes questões públicas e o tema que se anuncia na sequência, voltado à vida privada dos personagens:

\footnotetext{
${ }^{4}$ Reardon (2006, p.232) fala em "escola de Cáriton", sugerindo que o romance tenha sido uma espécie de best-seller de uma série de textos produzidos em meados do século I d.C. (Nino, Chione, Metíoco e Partenope).

5 "On many occasions he quotes Homer, not, as it were, an illustrative parentheses, but to carry the main narrative forward; for a brief moment the narrator's microphone passes to the poet. Every one of these quotations is in effect a familiarizing comparison for the benefit of an ostentantiously bookish narrate". (Morgan, 2004, p.485).
} 


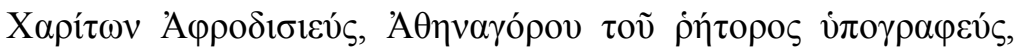

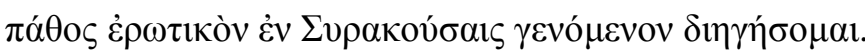

Eu, Cáriton de Afrodísias, secretário do retor Atenágoras, narrarei uma paixão erótica acontecida em Siracusa.

O uso do nome próprio ${ }^{6}$ na abertura da obra evoca a historiografia clássica e o

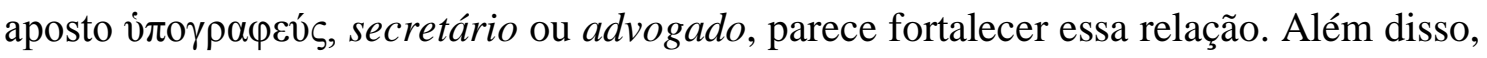

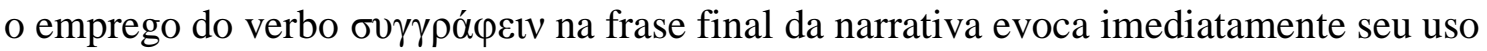
na abertura de A História da Guerra do Peloponeso de Tucídides e, como observa Brandão (2005, p.114), aponta nesse período com mais propriedade à escritura da história: "mais importante é que o narrador se apresente como hypographeús, isto é, escriba, notário, secretário - o que dá à sua narrativa certo ar documental". Não se trata de qualquer escritor, mas o de um tipo que deve manter algum controle sobre sua liberdade autoral, de modo que fique garantido o registro dos fatos. ${ }^{7}$ Além disso, historiadores contemporâneos a Cáriton não utilizavam a fórmula com que ele introduz o romance, o que parece indicar que o autor desejava "comunicar, desde o início, o espírito da própria época em que o enredo se passa" (Hägg, 1987, p.195).

Já se levantou também a hipótese de que o prólogo fosse fictício ou o nome do autor, um pseudônimo, por se considerar demasiadamente apropriado que um escritor da cidade de Afrodite, a deusa do amor, cujo nome faz referência às Graças (Cárites), fosse o autor de uma paixão erótica. Se fictício, o Atenágoras mencionado poderia fazer referência ao mesmo indivíduo que Tucídides apresenta como oponente de Hermócrates (VI.35-40), travestindo-se, assim, o romance de relato de testemunha ocular dos acontecimentos em Siracusa, como sugeriu D’Orville (apud Tilg, 2010, p.49ss), responsável pela primeira edição do texto de Cáriton, em 1750, e que menciona também a possibilidade de certo "retor Atenágoras" citado em um epigrama de Amiano de

\footnotetext{
${ }^{6}$ Cf. Doulamis (2012) para discussão sobre relação entre autor/narrador em Cáriton.

${ }^{7}$ A escolha do verbo "narrar" ( $\left.\delta \eta \eta \gamma \eta ́ \sigma o \mu \alpha\right)$ no proêmio de Quéreas e Calírroe com vistas a evocar a historiografia clássica foi recentemente colocada em questão por Tilg (2010, p. 218), que, ao contrário, vê

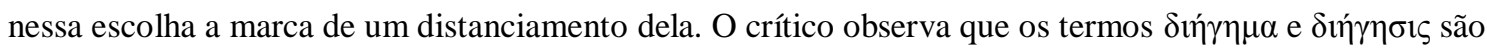
raros em historiadores clássicos e, de fato, ausentes em Heródoto, Tucídides e Xenofonte. Obras de historiografia posteriores, em que o uso do verbo se torna mais comum, teriam sido influenciadas por um conceito retórico de narrativa como discutida nos progymnasmata, que classifica a historiografia na categoria de $\delta$ iń $\gamma \eta \alpha$.
} 
Esmirna ser o mesmo que Cáriton nomeia em seu proêmio. ${ }^{8}$ Ainda que alguns críticos continuem a achar plausível o uso do pseudônimo, descobertas arqueológicas em Afrodísias parecem contextualizar historicamente a criação de Quéreas e Calírroe de modo convincente. ${ }^{9}$ Hoje temos conhecimento de inscrições da cidade que mencionam tanto o nome Cáriton como Atenágoras e talvez possamos até identificar a figura histórica cujo nome é mencionado no início do romance. ${ }^{10}$

Por fim, o páthos erotikón evidencia a centralidade do elemento amoroso na narrativa, sobrepujando os demais, que se configuram fortemente, ao longo do romance, como questões da esfera pública e política. ${ }^{11}$ A tensão acentuada entre esses dois polos se encerra, no fim, em uma sugestão de coexistência harmoniosa: demonstraremos que

\footnotetext{
${ }^{8}$ Antologia Palatina, XI.150:

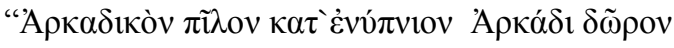

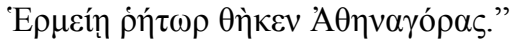

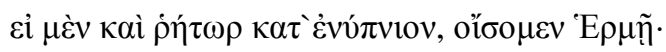

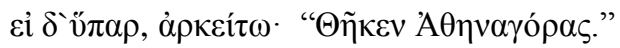

O fato de a expressão "retor Atenágoras" estar presente nos dois textos é um argumento relevante, mas pouco se sabe a respeito de Amiano que possa corroborar essa suspeita. Ruiz Montero sugere para ele uma datação nas primeiras décadas do século II d. C. Ao considerar os dois Atenágoras a mesma pessoa e ao sugerir que Cáriton tenha sido contemporâneo de Amiano, ela leva em consideração o epigrama para apresentar uma hipótese também sobre a datação de Cáriton na virada do século I para o século II d.C. Cf. Ruiz Montero (1980, apud Tilg, op.cit., p.51).

${ }^{9}$ Nesse sentido, o artigo de Edwards (1994) foi marco importante na história crítica de Cáriton, pois foi o primeiro a analisar a produção do romance relacionando-o a um contexto social específico da cidade de Afrodísias, hoje considerada o possível berço e um centro de produção do gênero. Edwards destaca a prosperidade de Afrodísias e apresenta testemunhos de que Roma, no período, tinha estabelecido relações fortemente favoráveis com Afrodísias, justificadas, ao menos inicialmente, pela alegada descendência de Otávio a partir de Enéas, filho de Afrodite, a deusa da cidade. Cf. também Edwards (1998).

${ }^{10}$ Tilg (2010, p.49ss). Antes da análise do crítico, as inscrições encontradas em Afrodísias tinham sido utilizadas apenas para comprovar o uso dos nomes na cidade. Tilg é o primeiro a tentar identificar de qual dos Atenágoras, Cáriton teria sido secretário. Na árvore genealógica desenhada por Reynolds (1999 apud Tilg, op.cit., p.53), os candidatos principais seriam Atenágoras filho de Atenágoras e seu bisneto, Flavius Athenagoras Agathos, procurador do Império e que veio a se tornar pai de um senador romano (esse último nascido, possivelmente, no último quarto do século I d.C.). A identificação é difícil, porém, porque não há referências de que o primeiro tenha sido retor.

${ }^{11}$ Brandão discute a expressão "páthos erotikón” (2005, 183ss): "a especialização do termo registra-se em testemunhos como o de Partênio, ao apresentar seu livro como áthroisin tôn erotikôn pathemáton 'coleção de paixões amorosas' ou, como se costuma traduzir, coleção de romances de amor'. 
não é por acaso que, no último livro, sejam celebrados concomitantemente o amor entre Calírroe e Quéreas e a sua vitória militar.

\section{II.1 Resumo do enredo}

A aproximação e a distância marcadas no proêmio de Quéreas e Calírroe entre romance e historiografia são mantidas ao longo da narrativa. Se na frase inicial o autor faz questão de declarar sua cidade e profissão, dando sinais mais ou menos evidentes do período em que está escrevendo, na sequência a narração se volta imediatamente a um passado distante. Vejamos a passagem que se segue ao proêmio do romance:

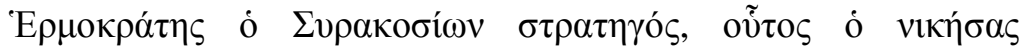

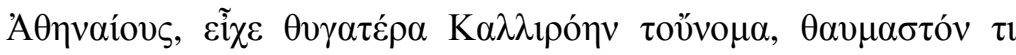

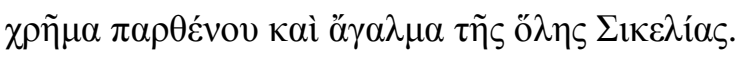

Hermócrates, o general de Siracusa, aquele que venceu os atenienses, tinha uma filha cujo nome era Calírroe, uma maravilha de moça e orgulho de toda a Sicília.

Anuncia-se aí que o páthos erotikón a ser narrado passa por um dos episódios mais conhecidos da Antiguidade: a derrota de Atenas na expedição à Sicília. Localizada a ação em Siracusa, no período clássico da história grega, a narração continua com o relato do amor à primeira vista de Quéreas e Calírroe. Filhos de pais inimigos políticos, o casamento só é acordado quando, em assembleia, o povo da cidade pede para que Hermócrates permita que os dois se casem. Calírroe, no entanto, tinha muitos pretendentes e, após o casamento, parte dos preteridos decide se vingar, arquitetando uma trama que acaba por convencer Quéreas de que Calírroe lhe era infiel.

O plano elaborado pelos antigos pretendentes de Calírroe funciona e, “dominado pela raiva", Quéreas a chuta com tanta violência que acredita ter provocado sua morte. Calírroe, em uma morte aparente, acaba então sendo sepultada viva. É nesse momento que o pirata Téron, que observava o funeral, percebendo o quanto poderia lucrar com os tesouros enterrados juntos com Calírroe, resolve convencer um bando a violar a tumba. 
É ele quem descobre, na sequência, que ela estava viva e percebe que vendê-la como escrava seria muito mais rentável do que apenas saquear o tesouro ali enterrado. Aí começam as aventuras da heroína.

Vendida como escrava em Mileto, ela a princípio se mantém fiel a Quéreas, mas ao se descobrir grávida, passa por um grande dilema e, aconselhada pela serva Plângon, decide contrair segundas núpcias com o seu senhor, Dionísio, um grego rico e benevolente que há pouco tempo havia se tornado viúvo e que é levado a acreditar ser dele o filho. Enquanto o novo casamento acontece, a ação volta à Siracusa, onde Quéreas descobre a tumba violada e a esposa desaparecida. Navios então partem à sua procura, até que Quéreas encontra Téron como o único sobrevivente de uma embarcação à deriva. Levado à Siracusa, ele confessa ter vendido Calírroe como escrava na Jônia e é sentenciado à morte logo em seguida.

Quéreas, já ciente da armação dos seus opositores, e seu fiel amigo Policarmo partem imediatamente para Mileto, mas acabam revelando sua identidade diante de uma estátua de Calírroe, quando então são informados do seu segundo casamento. Focas, administrador da propriedade de Dionísio e zeloso da felicidade do seu patrão, informando-se sobre a trirreme de guerra que ali chegara com Quéreas, trama para que ela seja atacada pelo contingente persa local. Dionísio, informado posteriormente do acontecido, sente-se aliviado ao acreditar que Quéreas está morto. Na verdade, porém, ele e Policarmo haviam sobrevivido ao ataque e trabalhavam como escravos para Mitridates, sátrapa da Cária.

Dionísio então informa Calírroe da chegada de uma nau siracusana a Mileto e da sua posterior destruição e, em seguida, para consolá-la, realiza um grande funeral para Quéreas. Nessa ocasião também Mitridates se apaixona por ela. Enquanto isso, forçados a trabalhar, Quéreas e Policarmo acabam envolvidos em um plano de fuga, mas são presos e condenados à crucificação. Mitridates poupa-os, no entanto, quando descobre que está diante do homem de cujo funeral ele acabara de voltar. É justamente o sátrapa que permitirá o reencontro entre os dois amantes, como resultado de um plano no qual ele pretendia usar Quéreas para chegar até Calírroe. Mitridates encoraja o herói a enviar uma carta para Calírroe, informando-lhe que está vivo, a qual é interceptada por Dionísio, que, por sua vez, sem saber que a carta é verdadeira, acaba por acusar o próprio Mitridates de cobiçar sua esposa, informando a situação a outra figura importante da política persa, Farnaces, sátrapa da Jônia (e mais um apaixonado por Calírroe). Este, em seguida, informa o Grande Rei da situação. 
O rei ordena, então, que os dois se desloquem até a Babilônia, para que ele decida qual dos dois tem razão em suas acusações (e ele também tinha curiosidade de conhecer a mulher cuja beleza já se tornara célebre na Ásia). Calírroe acompanha Dionísio e Mitridates leva consigo Quéreas, que permanece escondido até o momento em que estão todos presentes no tribunal, quando então sua aparição muda o foco do julgamento, que passa a ser a disputa entre Quéreas e Dionísio pelo direito à mão de Calírroe. A decisão, porém, é postergada pelo rei, que adia sua decisão porque ele próprio havia se apaixonado por ela. Aquele que é chamado de o homem mais poderoso na corte do rei (V.2.3.) e o mais confiável deles (VI.3.1), o eunuco Artaxates, aborda-a de diversas formas para convencê-la a se entregar ao Grande Rei, Artaxerxes, sem sucesso.

É nesse ponto da história (VI.8) que ocorre o episódio bélico: uma revolta irrompe no Egito e rapidamente se espalha para a Fenícia e a Síria. O controle dessa rebelião ocupa todo o sétimo livro do romance. O rei reúne suas forças para contê-la e parte levando consigo sua esposa e outras mulheres da corte persa (entre elas, Calírroe), bem como parte do seu tesouro. Quéreas, no entanto, acredita que o rei havia resolvido entregá-la a Dionísio e é convencido por Policarmo a se unir aos rebeldes em uma missão suicida. O herói acaba por liderar trezentos mercenários gregos na captura da cidade de Tiro, fortificada e de difícil acesso. Em seguida, ele recebe o comando da força naval. Os egípcios são derrotados em terra por Dionísio, mas Quéreas derrota a marinha persa e captura Arado, onde estavam o tesouro do rei e as mulheres persas e, entre elas, Calírroe.

Nesse momento, o narrador afirma que havia cessado a irritação de Afrodite contra Quéreas por ele ter agido com violência contra a mais bela dádiva que um homem havia recebido. Calírroe volta para Siracusa com Quéreas, deixando seu filho com Dionísio, com a instrução de que ele também fosse enviado para Siracusa quando adulto. Depois que toda a cidade admira Quéreas e Calírroe na assembleia, ele fica sozinho para contar aos seus concidadãos o que havia se passado desde que ele partira da cidade em busca da esposa. A narrativa se encerra com Calírroe fazendo uma prece no templo de Afrodite para que nunca mais se separe de Quéreas.

\section{II.2 Relações entre historiografia e Eros: como ser homem (público)}


A partir dessa paráfrase do enredo, pode-se observar que os personagens principais de Cáriton movem-se e têm parte decisiva numa esfera política que envolve não só a cidade de Siracusa, mas também o Império Persa, o que é reflexo da relação que o autor escolhe manter com a historiografia clássica. Embora, como observa Reardon, "as pressuposições inconscientes que subjazem na história” (1996, p.326) estejam de acordo com aquelas do período do Império Romano, o "colorido histórico" é sentido nas alusões que os leitores poderiam reconhecer na tradição literária grega. Isso tem consequências na criação dos personagens masculinos, que ocupam posições sociais no romance que lhes permitiriam vir a ser igualmente personagens de narrativas historiográficas. Como nota Alvares (1997, p.620), o que acontece com Calírroe na corte persa "deve ser visto em relação aos relatos de história persa como uma série de intrigas da corte e do harém, que remontam a Ctésias e a Duris e que pode ser observada em A Vida de Artaxerxes, de Plutarco".

É ao se centrar nos dilemas individuais dos personagens, porém, que Cáriton introduz elementos típicos do romance em temas que dizem respeito tradicionalmente à historiografia. Isso é acompanhado pela forma assumida pela narrativa; o aspecto dramático é acentuado pelas técnicas do autor, que pouco narra as ações em sumário, preferindo, como analisou Hägg em seu importante estudo de 1971, centrar-se nas reações que tais ações provocam nos personagens, as quais ganham importância a partir da sua percepção dos fatos. Reardon (1999, p.173), a partir do estudo de Hägg, aponta que praticamente $90 \%$ do texto é narrado em cena e cerca de metade disso em discurso direto. As emoções estão, assim, no centro da narrativa.

Se, por um lado, a impressão de registro histórico é criada a partir de um conhecimento literário comum, o romance, como praticado na Antiguidade, por outro lado, permitia desvios consideráveis dos textos dos quais seus leitores possivelmente tinham conhecimento. Podemos observar mais claramente esse processo nos poucos fragmentos conhecidos de Nino. O tratamento idealizado do personagem, rei lendário fundador do Império Assírio, levou à hipótese de que a obra fosse uma espécie de Ninopédia, fortemente influenciada pela Ciropédia de Xenofonte. Há que se considerar que nossa principal fonte histórica sobre Nino e sua esposa Semíramis ${ }^{12}$ é um breve

\footnotetext{
${ }^{12}$ O nome de Semíramis não aparece nos fragmentos, mas em Diodoro Sículo se diz que ela é filha da deusa Derceto e o nome de sua mãe nos fragmentos é Derceia, claramente um derivado. Ainda que o
} 
sumário de Diodoro Sículo (II.1-20) do que teria escrito a respeito dos dois o historiador do século IV a.C Ctésias de Cnido, já na Antiguidade famoso e censurado pelas mentiras que dizia. ${ }^{13}$

Porém, as diferenças entre a Semíramis de Ctésias e a do autor de Nino são muitas e permitem avaliar a liberdade dos romancistas no processo de idealização típica do gênero. ${ }^{14}$ No fragmento A, o futuro rei, apaixonado por sua prima, confronta a mãe de sua futura esposa argumentando contra a convenção que estabelece quinze anos como a idade apropriada para uma moça se casar, pois Semíramis teria ainda de esperar dois anos até que os dois pudessem celebrar sua união. A Semíramis do romance é, ao menos na passagem que possuímos, tão acanhada que sequer consegue tocar no assunto casamento com sua tia, a mãe de Nino (fr.A-IV.20-37):

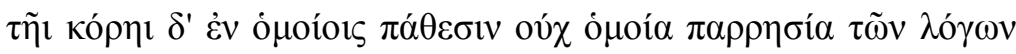

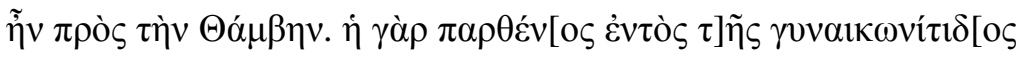
$\zeta \tilde{\omega} \sigma \alpha$ o]

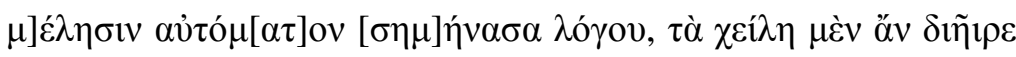

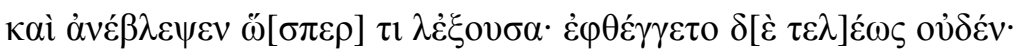

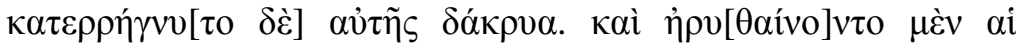

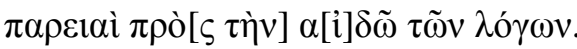

A moça, que passava pelos mesmos sofrimentos, não tinha a mesma eloquência diante de Tiambe, pois como virgem que vivia no interior dos aposentos reservados às mulheres, não conseguia dizer as palavras adequadas. [...] Demonstrando espontaneamente sua intenção de falar, abria a boca e encarava-a como se fosse dizer alguma coisa, mas não completava uma palavra. Suas lágrimas escorriam e as faces ruborizavam pela vergonha de falar.

casamento de Nino com Semíramis tenha aparentemente se tornado um tema tradicional da historiografia grega, há uma distância de cerca de 1500 anos entre os períodos em que cada um deles teria vivido.

13 O primeiro crítico talvez tenha sido Aristóteles (cf. Hist.Anim. 606a8), mas ele é criticado com severidade por Estrabão e Fócio (cod.72) e é considerado um paradigma de autor mentiroso por Luciano nas Histórias Verdadeiras (I.2). Sobre o autor, cf. Cizek, (1975), Holzberg (1996) e Romm (1989).

${ }^{14}$ Hansen (1997) chama a atenção para o processo de idealização no romance grego em outra perspectiva, ao analisar como situações tradicionalmente cômicas são nele reelaboradas. 
Essa cena pouco tem a ver com a Semíramis da tradição historiográfica que conhecemos. Isso não significa, porém, que ela forneça um retrato "realista" da rainha, figura mítica que adquiriu progressivamente características que a associam à deusa mesopotâmica Ishtar que, por sua vez, é relacionada sobretudo às esferas amorosa e militar. ${ }^{15}$ Diodoro Sículo diz, a partir da obra de Ctésias, que Nino se casa com Semíramis, durante uma expedição contra a Báctria, tomando-a do seu marido Onnes, seu aliado (que por isso se mata). Nessa campanha, Semíramis tem oportunidade de demonstrar sua habilidade como estrategista, ajudando o exército a tomar a última cidade que permanecia em resistência, chamando assim a atenção do rei. Após a morte de Nino, Semíramis teria sido responsável por fundar a cidade de Babilônia e por liderar campanhas militares no Egito, na Etiópia e na Índia, sendo derrotada apenas nesse último país. Diodoro (II.13.4) diz ainda que a rainha se entregava à luxúria e, tendo receio de perder o poder, não desejava se casar, mas escolhia alguns soldados e depois matava todos aqueles com quem havia mantido relações. Depois de relatar a versão de Ctésias, Diodoro (II.20.3-5) afirma que outras fontes dizem que Semíramis era, na verdade, uma cortesã, que conseguiu ganhar a preferência e depois se casar com Nino. Como esposa, ela teria convencido o rei a deixá-la governar em seu lugar durante cinco dias, período no qual conspirou contra o próprio marido e o assassinou, tomando o poder de forma permanente.

Diferentemente do autor de Nino, Cáriton toma como ponto de partida um fato bastante conhecido da história grega, mas também seleciona e reelabora diversos de seus elementos. A leitura de Tucídides não parece indicar que Hermócrates fosse o responsável por liderar as operações militares em Siracusa e o sucesso da cidade parece depender mais da atuação do espartano Gilipo. No entanto, Diodoro Sículo (13.96.3) o menciona como responsável por derrotar os atenienses em guerra e, no momento em que Cáriton escreve, tanto Siracusa quanto Hermócrates já haviam recebido tratamento idealizado diversas vezes, não só com relação a sua excelência militar, mas também a uma perfeição moral (Billaut, 1989). A ideia de que Hermócrates é o responsável pela vitória de Siracusa é repetida tantas vezes no romance que, para Billaut (idem, p.542),

\footnotetext{
${ }^{15}$ Nisso pode se perceber um paralelo entre Semíramis e os papéis desempenhados por Afrodite e Calírroe no que diz respeito não apenas ao universo erótico, mas também à guerra, em Quéreas $e$ Calírroe.
} 
"[ela] tem a pureza de uma abstração. Ela não contradiz a verdade histórica, mas aparece abstrata da história como sucessão de acontecimentos no tempo". ${ }^{16}$ No romance, o general é o principal líder político da cidade; mais do que isso, ele é uma figura que se impõe desde o início da narrativa como aquela que define quem são, afinal, Calírroe e Quéreas: ela é, como o narrador repete inúmeras vezes, a filha de Hermócrates, aquele que derrotou os atenienses; Quéreas é o seu genro. Em determinada passagem do romance, irritada ao ouvir o eunuco Artaxates dizer que ela prefere o "escravo de Mitridates" ao próprio rei, Calírroe tenta provar a grandeza e a superioridade de Quéreas ao persa por meio de um raciocínio que se centra na história militar das pátrias de um e de outro (VI.7.9-10):

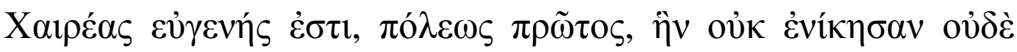

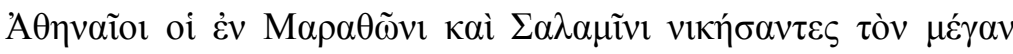
боv $\beta \alpha \sigma i \lambda \varepsilon ́ \alpha$.
\end{abstract}

Quéreas é nobre, o primeiro de uma cidade que nem os atenienses derrotaram, aqueles que em Maratona e em Salamina venceram o teu Grande Rei.

Nada se diz no romance sobre o governo democrático em Siracusa que acabou por exilar o general, muito menos sobre o golpe que ele então empreende para tomar a cidade, durante o qual acaba morto. Dionísio I, aliado de Hermócrates que, por fim, torna-se tirano de Siracusa, teria se casado com sua filha. Plutarco (Dionísio, 3.1-2), que não registra seu nome, diz que ela teria se suicidado após ter sido violentada por um grupo de rebeldes. Assim, como observa Tilg (2010, p. 155), "o fim histórico trágico dos dois é substituído por um romântico final feliz".

Parece, portanto, que os romancistas consideraram ser apropriado, quando trabalhavam com material historiográfico, selecionar eventos sobre os quais seus

\footnotetext{
${ }^{16}$ Billaut (idem, ibidem) observa, contudo, que"nul doute qu'aux yeux de Thucydide il ne réunisse les vertus nécessaires à un chef de valeur: l'energie, l'acuité intellectuelle, la capacité à prévooir les événements, le courage, aussi, de contredire l'opinion du peuple". O crítico analisa a representação de Hermócrates não só em Tucídides e Xenofonte, mas em Timeu de Tauromenon, Políbio, Diodoro Sículo e Plutarco, dando, porém, especial atenção ao Hermócrates do diálogo platônico Timeu.
} 
leitores teriam um conhecimento lacunar. ${ }^{17}$ Esse é um dos motivos por que Téron, a despeito da sugestão dos companheiros, decide não tentar vender Calírroe em Atenas,

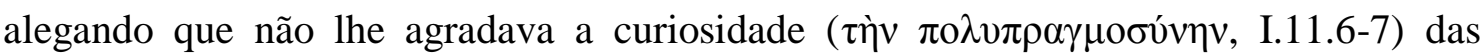
pessoas da cidade: "é um povo tagarela e amante dos tribunais e, no porto, sicofantas aos milhares vão querer saber quem somos e de onde trazemos as mercadorias [...]. E logo ali está o Areópago e os magistrados, mais severos que tiranos". É natural que se levante a possibilidade de Calírroe ir parar em Atenas, já que a cidade é evocada desde o início do romance pela vitória militar de Hermócrates. A própria Calírroe, quando raptada pelos piratas, expressa seu receio de acabar escrava de um senhor ateniense. Para ela, há ironia no fato de que isso viria a concretizar uma situação que havia sido evitada com a vitória de Siracusa em guerra, mas a ideia surge para ser logo depois descartada. Em função da própria forma como a disputa por Calírroe é representada, uma passagem por Atenas traria ao universo do romance outros personagens históricos mais familiares aos leitores, uma vez que ela desperta o desejo de pretendentes que têm posição política de destaque, influenciando em sua atuação. Assim, a reescrita com final feliz de eventos históricos em um novo gênero, com novo sistema de valores e no qual é possível dar a conhecer as motivações pessoais e eróticas dos homens públicos que determinam o destino de um coletivo, só pode se dar em um espaço que favoreça a inserção de elementos fictícios. ${ }^{18}$

\footnotetext{
${ }^{17}$ Além de Quéreas e Calírroe e Nino, também pensamos nos fragmentos de Metíoco e Partenope. O uso da historiografia em Cáriton com objetivo de manter a narrativa dentro dos parâmetros de realidade dos leitores e assim estabelecer sua crença ficcional é discutido por Morgan (1993).

${ }^{18}$ A recusa de Téron é também, como sugeriram alguns críticos, uma escolha anunciada de Cáriton de se distanciar de gêneros literários mais antigos. Kaspryzk (2001) observa que uma das funções do pirata, ao levar primeiro a heroína à Ásia e, em seguida, o herói, é possibilitar um elemento que diferencia o romance da comédia nova. De início, a intriga amorosa e o vocabulário teatral no episódio da conspiração dos ex-pretendentes sugerem uma aproximação com o gênero (cf. Lowe, 2000 e Mason, 2002). A trama dos ex-pretendentes faz lembrar as intrigas da comédia nova e o autor do plano para incriminar Calírroe é

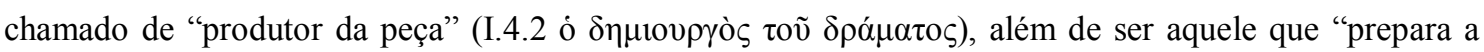

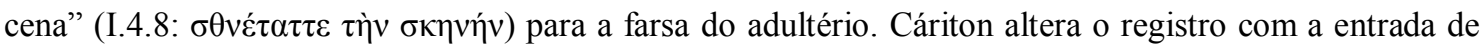
Téron na narrativa. "Graças a ele abandonam-se simultaneamente o mundo da cidade e o do teatro, para que se invista no mundo oriental, terra de aventura, e se entre verdadeiramente no romance” (Kaspryzk, 2001, p.154). No nível metaliterário, Smith (2007, p. 66ss.) considera que se trata também de uma recusa da historiografia ática, bem como Tilg (2010, p. 32 ss.) que, além disso, sugere a relação do romance com os contos milésios como motivação para a escolha de Mileto como destino dos personagens. Para a escolha de Mileto como cidade onde boa parte da ação se passa, cf. Trzaskoma (2012).
} 
Nesse sentido, é interessante a análise de Alvares (1997), que discute como Cáriton adapta motivos conhecidos da historiografia para criar um contraste com o gênero, pois elementos políticos e sociais teriam sua importância diminuída ao serem representados como meros elementos do poder de Afrodite. E poderíamos ver isso acontecer não apenas quando Dionísio, Mitridates e o próprio rei Artaxerxes se apaixonam por Calírroe, três homens que são da maior importância no universo político persa e que, quando a conhecem, passam a atuar dentro dessa esfera influenciados pelos seus sentimentos. Além disso, a própria estrutura geral dos acontecimentos é organizada em torno do poder de Afrodite, uma vez que ao final do romance se revela que tudo o que aconteceu com Quéreas após a morte aparente de Calírroe foi motivado pelo descontentamento da deusa com ele.

Discordo, porém, da sua interpretação da narrativa. Para Alvares, o período glorioso de Siracusa estaria distante e mítico o suficiente no momento em que Cáriton compõe seu romance para permitir ser reescrito numa "história alternativa", de forma a demonstrar que seguir os valores de Afrodite pode levar a uma trajetória política de sucesso. A nova ordem que Quéreas, ao lado de sua esposa, inauguraria seria superior às realizações do passado e "resultado da devoção aos valores eróticos". O crítico argumenta que os principais rivais de Quéreas não demonstram possuí-los, sugerindo que a regra no romance é que se deve ter um único par durante toda a vida e que, por isso, Dionísio agiria de forma inapropriada ao esquecer sua falecida esposa e se casar com Calírroe, não sendo, portanto, digno de um final feliz. Devemos considerar, porém, que o próprio Quéreas (VII.1.6) parece acreditar que o segundo casamento de Calírroe seria compreensível se ele estivesse morto. ${ }^{19}$ Além disso, a relação entre amor e sucesso político, de fato, não é apresentada pelo narrador como uma equação simples, como discutimos na sequência.

Nesse cenário político-historiográfico que Cáriton desenha como pano de fundo da sua história de amor, a representação da masculinidade necessariamente lida com ideais que dizem respeito à liderança e à atuação militar, ${ }^{20}$ como é marcante desde o início da narrativa pelas menções a Hermócrates como figura digna de admiração, e é

\footnotetext{
${ }^{19}$ Segundo Alvares, o Grande Rei, por sua vez, terminaria por apresentar os valores eróticos adequados na sua decisão de entregar Calírroe como recompensa a Dionísio e no apreço que demonstra por Estatira ao recuperá-la em um momento que acreditava tê-la perdido.

${ }^{20}$ Das quais fazem parte a habilidade retórica, cf. Lalanne (2006, p.156), de Temmerman (2009), Jones (2012, p.67-70).
} 
isso, em parte, que justifica a inserção do episódio bélico no texto. Em Quéreas e Calírroe, a guerra é, assim, uma oportunidade de enfatizar a andreia do herói e sua habilidade retórica e política. Embora a partir daí o episódio bélico tenha se tornado uma convenção do romance do amor, nos outros exemplares conhecidos ele não exibe essa mesma função, possivelmente porque as relações intertextuais com a historiografia tornam-se mais complexas e exploram menos o conhecimento lacunar dos leitores para criar impressão de autenticidade.

Para entender como se dá a representação da masculinidade em Quéreas $e$ Calírroe, o ponto de partida essencial é a análise de Balot (1998), que utiliza a abordagem ética de Foucault para fazer uma leitura sólida dos personagens masculinos e de como Eros afeta a construção de suas identidades, chamando a atenção para a forma pela qual o romance dramatiza o conflito entre autocontrole e paixão erótica em todos os pretendentes de Calírroe (especialmente Dionísio), que uma vez apaixonados têm dificuldade de manter seus ideais de comportamento (1998, p.141):

\begin{abstract}
A autoconstrução dos personagens masculinos faz com que eles tenham em mente de modo consistente ideais de autocontrole, racionalidade e, por fim, de valor marcial [...]. Seus conflitos éticos são conflitos justamente para moldar e constituir sua individualidade de acordo com ideais sociais mais amplos.
\end{abstract}

A análise de Balot demonstra como essa tensão provocada por Eros acaba por envolver a capacidade dos personagens de desempenhar suas funções como homens públicos, algo que eles só conseguem retomar plenamente quando irrompe a guerra por causa da revolta egípcia. Isso fica bastante claro na representação do efeito do amor por Calírroe sobre o Grande Rei. Ele é apresentado ao leitor, ao menos inicialmente, como um bárbaro que mantém os elevados padrões da paideia grega (V.4.8, V.7.1), mas que em determinado ponto não consegue definir para si mesmo se é "amante de Calírroe ou

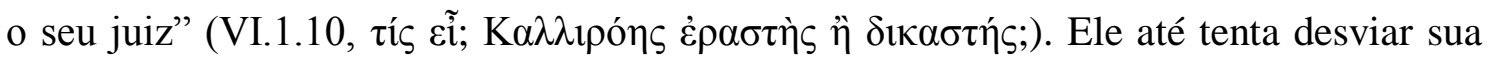
atenção da moça ao sair para caçar, mas mesmo assim o que ele acaba tendo em mente o tempo todo é se Calírroe o observaria na pompa com a qual havia se ornamentado (VI.4). Incapaz de "articular sequer o papel que possui, muito menos de viver de acordo com os ideais desejados pela sociedade" (Balot, idem, p.153), o rei se deixa convencer pelo eunuco Artaxates de que não haveria adultério, uma vez que Calírroe 
ainda não tinha, de fato, um marido, pois ainda não se havia decidido quem deveria ocupar o posto, se Quéreas ou Dionísio.

A maioria das análises posteriores da questão da masculinidade em Cáriton de Afrodísias parte dessa leitura, oferecendo contribuições menores. A meu ver a principal

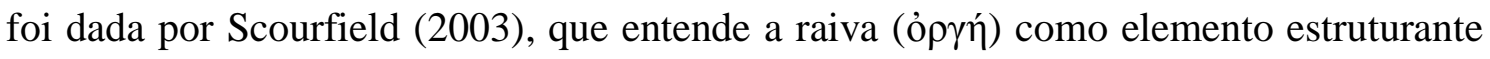

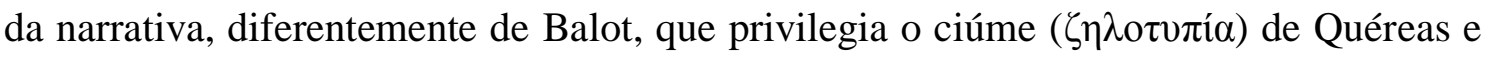
de Dionísio (e suas consequências negativas) entre os sentimentos masculinos que devem ser controlados. Nossa leitura do romance segue a de Balot e a de Scourfield em boa parte, mas se pretende demonstrar como Cáriton aborda a raiva do personagem de Quéreas de acordo com noções do período sobre seus aspectos positivos ou negativos, que dependem principalmente de um contexto apropriado de manifestação. Tradicionalmente, a boa imagem de um líder político dependia da exibição da sua capacidade de autocontrole (sophrosyne), inclusive de emoções como a raiva, ${ }^{21}$ e aqui concordo com Lalanne (2006, p.156ss) que Cáriton representa uma incapacidade inicial de Quéreas, que é a princípio “impaciente, colérico e violento”. Por outro lado, sugerese ao longo da narrativa que Eros e a manutenção de ideais de masculinidade e de liderança são duas coisas incompatíveis. O final do romance mostra que é possível conciliá-los, mas que isso depende de um aprendizado da parte de Quéreas, no qual a guerra tem função central.

\section{II.3 A Guerra por Calírroe}

\footnotetext{
${ }^{21}$ Cf. Harris (2004, p.229-263). Aristóteles define a raiva (orgé) na Retórica (1378a) como “um desejo, acompanhado de dor, de uma vingança aparente contra um desrespeito aparente para com uma pessoa

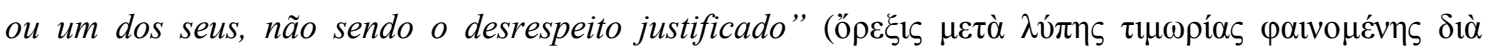

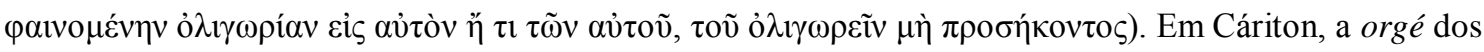
pretendentes, de Quéreas e de Afrodite levam ao desejo de vigança. Konstan (2003), Harris (2004, p.57ss), Rowe (2012) discutem essa definição. Sobre a concepção de raiva na Antiguidade grega e o estudo transcultural dessa emoção, cf. Cairns (2003), que discute a questão da universalidade e da especificidade cultural das emoções. O crítico chega à conclusão de que a variação cultural, ao menos com relação à raiva, não é irrestrita: "there is indeed a considerable degree of cross-ciltural commonality in the conceptualization of anger", sendo a raiva fundamentalmente entendida em variadas culturas como resposta a uma ofensa. Sobre a relação entre insulto e raiva, cf. Aristóteles, Pol.1311a33.
} 
Para Hunter (1994), que defende que a contenda por Calírroe representa um embate por poder político, o uso do verbo $\lambda \alpha \mu \beta \alpha ́ v o \mu \alpha$ no trecho citado a seguir (III.4.18) tem como complemento o pronome relativo ìv, que faria referência ao sintagma "filha de Hermócrates" e que seria usado de forma propositadamente inadequada. Como afirma o crítico, "é como se Calírroe tivesse sido o objeto da expedição ateniense", não a cidade de Siracusa:

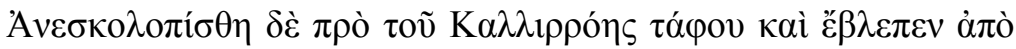

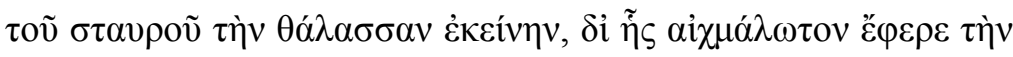

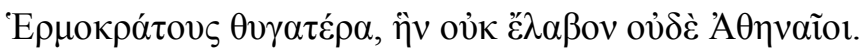

[Téron] foi crucificado diante do túmulo de Calírroe, enquanto observava da cruz aquele mar por onde levara a filha de Hermócrates como cativa, que nem os atenienses haviam conseguido tomar. ${ }^{22}$

De fato, a vida de Calírroe mobiliza a cidade. Em primeiro lugar, é o povo que convence Hermócrates a deixar de lado uma antiga rixa política e a conceder a sua mão a Quéreas. Quando sua tumba é descoberta vazia, trirremes são imediatamente lançadas ao mar e muitos participam da busca (III.3.8). Depois que Téron é encontrado, ele é levado para ser interrogado na assembleia e, quando se revela que Calírroe foi vendida como escrava, Hermócrates anuncia uma ordem não de recuperar sua filha, mas de

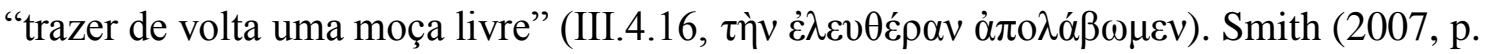
177) fez uma observação precisa ao afirmar que "ao identificá-la pelo seu status político, Hermócrates define a missão de resgate não como uma vingança pessoal, mas como prerrogativa do estado". Não é por acaso, portanto, que Calírroe retorne à Siracusa em função de ações que não envolvem apenas a atuação particular dos personagens. Que os assuntos de Eros e Afrodite podem resultar em guerra é algo que estava demonstrado desde Homero. ${ }^{23}$ Antes que irrompa a revolta egípcia no livro VI,

\footnotetext{
${ }^{22}$ Sousa e Silva (1996), que assina a tradução portuguesa do romance, entende que o pronome relativo îv refere-se à $\tau \grave{\eta} v \theta \alpha ́ \lambda \alpha \sigma \sigma \alpha v$. Reardon (1989), na tradução inglesa da coletânea de romances gregos por ele organizada, concorda com Hunter.

${ }^{23}$ Cáriton se vale de alusões aos dois maridos de Helena algumas vezes, mas de uma forma complexa, que evita simplesmente identificar Quéreas, o primeiro marido, com Menelau, e Dionísio, o segundo, com Páris. Por duas vezes Dionísio se vê no papel de Menelau, temendo perder sua Helena (II.6.1 e V.2.8)
} 
porém, a relação entre amor e guerra é explorada em diversas passagens que dizem respeito à disputa por Calírroe. ${ }^{24}$

No período em que Cáriton escreve seu romance, a tópica do militia amoris já havia sido bastante desenvolvida na elegia erótica latina. ${ }^{25} \mathrm{O}$ desenvolvimento dado por Cáriton à relação entre amor e guerra é, porém, bastante diversa daquela observada nos elegíacos latinos. É fato que sua presença é mais do que meramente ornamental, pois anuncia o episódio que resolve uma rivalidade que constitui o centro estrutural da narrativa. ${ }^{26}$ Disputada por vários pretendentes por causa da beleza, Calírroe é considerada uma nova Helena, ${ }^{27}$ uma dádiva de Afrodite a Quéreas, de forma comparável ao da deusa, por quem algumas vezes é tomada, como no seu primeiro encontro com Dionísio, que imediatamente se prostra diante dela (II.3.5-8). Assim como Helena, ela também se casou duas vezes e teve antes muitos pretendentes, "dinastas $e$ filhos de tiranos, não apenas da Sicília, mas também do sul e do norte da Itália, e

para qualquer Páris. Quéreas é ainda comparado com Páris pelo dom que recebeu de Afrodite. Sobre o uso dos mitos troianos na narrativa, cf. Laplace (1980). Contra, cf. Tilg (2010, p.150ss), para quem o mito troiano não seria o modelo principal para a história de Calírroe e que sugere influência das fábulas milésias e da Sybaritica.

24 Outra imagem apreciada por Cáriton é a que coloca os seus pretendentes em posição de atletas participando de competições esportivas para obtê-la como prêmio (I.2.2 e VI.2.1-2).

${ }^{25}$ Cahoon (1988), analisando as imagens empregadas por Ovídio em Amores, sugere que o poeta, ao mesmo tempo que coloca em questão atitudes fundamentais da esfera pública romana por meio dessa tópica, explora também a natureza violenta e destrutiva da própria relação erótica. Porém, ela foi utilizada pelos poetas elegíacos no geral com o objetivo de se dissociarem da guerra, retratando a si mesmos como soldados de Cupido a fim de "realizar um contraste com e uma rejeição da carreira pública no exército Romano, algo que seria esperado deles pela sociedade" (Mckeown, 1995, p.297). Por outro lado, a tópica era utilizada para anunciar uma recusa da seriedade da épica em favor de uma poesia leve. Sobre a militia amoris na elegia erótica latina, cf. também Levin, (1982), Gale (1997) e Lyne (2002).

${ }^{26} \mathrm{Na}$ divisão proposta por Reardon (1999), que separa os oito livros em quatro partes e entende como corpo dos acontecimentos uma série de agones entre Quéreas e seus rivais: i) breve introdução (o casamento); ii) separação; iii) eventos principais (relações de Calírroe com Dionísio, Mitridates e o Rei); iv) Reencontro. Perry (1967, p.140ss), seguindo Reitzenstein (1906, p.92-99), havia percebido na história um drama helenístico de cinco atos: i) o casamento de Calírroe com Quéreas e Dionísio; 2) A escravidão de Quéreas; 3) o julgamento; 4) a guerra; 5) o reencontro. Reardon sugere, no mesmo artigo acima citado, ainda outra divisão (idem, p.169): os oito livros, como nos manuscritos, sugerem quatro estágios de desenvolvimento, divididos mais ou menos em dois livros cada, i) as aventuras de Calírroe; ii) as aventuras de Quéreas; iii) Quéreas e Calírroe juntos na Babilônia; iv) Quéreas mais uma vez.

${ }^{27}$ Sobre a influência das lendas de Troia em Cáriton, cf. Laplace (1980). 
estrangeiros que vivem lâ" ${ }^{28}$ É obra de Eros que ela não se apaixone por nenhum deles, mas fique cara a cara com Quéreas no momento em que ela saía de casa para ir ao templo de Afrodite, no dia do festival da deusa, bem no momento em que ele retornava do ginásio. A paixão é imediata; Quéreas volta para casa parecendo "um grande guerreiro ferido mortalmente em combate, envergonhado de cair, mas incapaz de se manter de pé" (I.1.7). ${ }^{29}$ Eros venceu sua primeira batalha no romance. O herói desiste de viver quando seu pai diz que não há chance de Hermócrates escolhê-lo como genro, mas seus amigos de ginásio, depois de se informarem sobre o mal que afligia Quéreas, apelam a Hermócrates durante a assembleia ordinária da cidade. Como observou

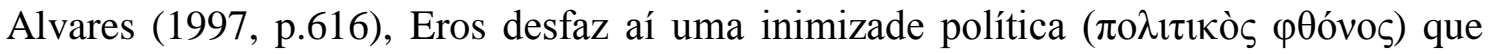
não seria benéfica a Siracusa, já que se sublinha que Hermógenes e Áriston, pai de Quéreas e "segundo homem da cidade", jamais fariam uma aliança entre si (I.1.4). Concedida a mão de Calírroe a Quéreas, o narrador diz que suas bodas foram (I.1.16)

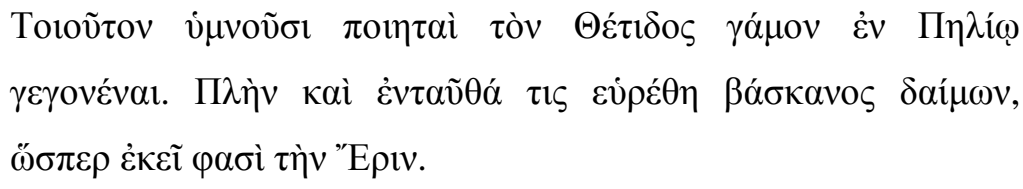

Tal como os poetas celebram o casamento de Tétis que ocorreu no Pélion. Além disso, também ali se descobriu um daímon maligno, como lá dizem ter estado a Discórdia.

Se a deusa Éris lançou no casamento de Tétis o pomo que veio a gerar a disputa entre as três deusas e, por conseguinte, a entrega de Helena a Páris e a guerra de Troia, no romance de Cáriton o dissenso não é divino, mas é uma iniciativa que parte dos antigos pretendentes de Calírroe. Nesse momento, o narrador volta a chamar a atenção para o fato de que alguns deles tinham relação com governos tirânicos. $\mathrm{O}$ filho do tirano de Régio se queixa do fato de que Quéreas "não fez nada" para merecer a mão de

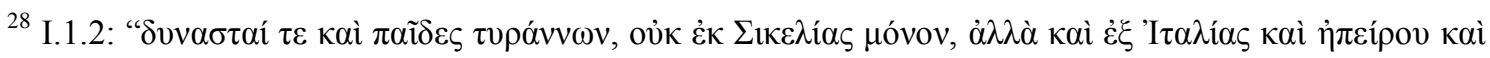
$\dot{\varepsilon} \theta v \tilde{\omega} v \tau \tilde{\omega} v \vee \dot{\varepsilon} v \dot{\eta} \pi \varepsilon i ́ p \omega "$ ". Reardon, na sua tradução do romance incluída na coletânea que organizou (1989), observa que (p.22, nota 3) nessa passagem Cáriton parece utilizar "Itália" apenas como sul da Itália, usando o nome próprio no que ele designava no grego clássico. O "continente" designa a região mais ao norte, helenizada, e as "tribos," os não gregos.

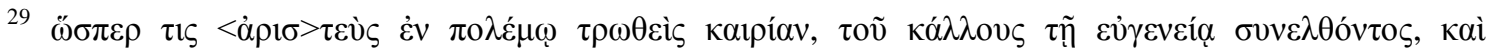

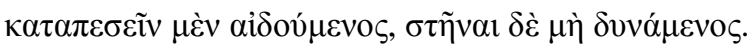


Calírroe, ao contrário dos pretendentes que se esforçavam para conquistá-la (I.2.2-3). Em seguida, o tirano de Agrigento é quem sugere o plano de atiçar o ciúme de Quéreas, lembrando, porém, que, por ser genro de Hermócrates, o melhor seria não entrar em luta

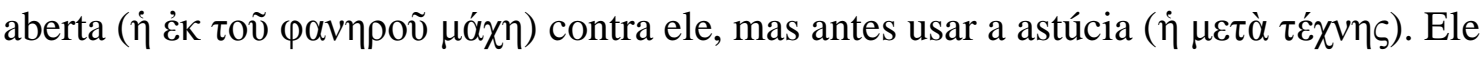

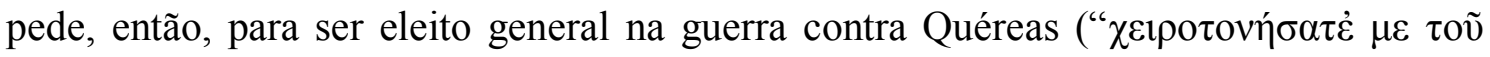

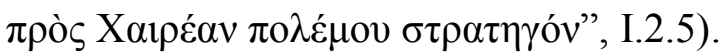

O plano dos pretendentes preteridos é de acabar com o casamento de Calírroe, mas o narrador sugere que ele tem o status de conspiração política. ${ }^{30}$ Afinal, ressalta-se desde o início do romance que a paixão erótica narrada envolve também questões públicas; a escolha do genro de Hermócrates, principal líder de Siracusa, terá consequências não apenas domésticas. Quéreas é escolhido como marido tanto por ela quanto pelos cidadãos reunidos em assembleia. Por isso, a conspiração dos pretendentes também se estende à própria organização política de Siracusa.

Mais adiante, o mesmo título de "general" dado ao antigo pretendente de Calírroe é usado para o pirata Téron, cuja grande ação na narrativa é arrombar a tumba da heroína, dessa forma salvando-a de ser enterrada vida. ${ }^{31}$ Quando é introduzido na narrativa, Téron percebe que precisaria de cúmplices para pilhar o túmulo de Calírroe e começa a pensar nos nomes daqueles que poderia convocar a participar de tal empreitada: "ao amanhecer correu ao porto e procurou cada um deles. Encontrou uns nos bordéis, outros nas tabernas; tal general, tal exército". 32 Téron não é um rival de Quéreas no amor por Calírroe, uma diferença importante no que concerne a personagens de piratas em romances posteriores. Guez (2001) supõe que Téron não se apaixona por ela porque a série de seus "predadores" (os rivais em Siracusa, Dionísio, Mitridates, Farnace, o Grande Rei) caracteriza-se por uma perfeita homogeneidade, incompatível com o status de um pirata. Uma vez que Quéreas deve "provar" que merece Calírroe, como adversários do herói, os seus vários pretendentes devem estar "em posição de contestá-lo simbolicamente como aquele que possui Calírroe” (idem, p.105), dando

\footnotetext{
${ }^{30}$ Laplace (1980, p.88-89) também analisa como esse episódio evoca os pretendentes de Helena.

${ }^{31}$ O que pode ter sido inspirado em uma situação real. Ruiz Montero (1989, p.193, n. 79) observa que os tymborichoi, arrombadores de túmulo, aparecem diversas vezes em fórmulas em Afrodísias, e Edwards (1985, p.177, n.14) chama a atenção para o fato de que havia multas a serem pagas a Afrodite contra esse tipo de delito na cidade.

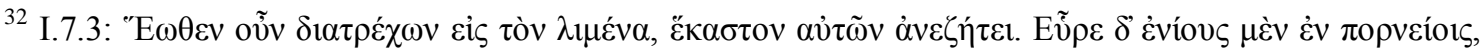

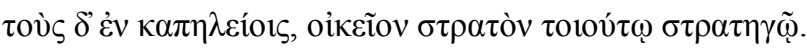


valor, por conseguinte, àquele que acaba por vencer a disputa. Téron não pode assumir essa função, mesmo que seu caráter e o mal que causa a Quéreas possam sugerir ao leitor uma comparação entre o bandido e o herói.

Seu grupo, porém, não é apenas uma ameaça à vida ou à propriedade particular de um cidadão, ele é um "elemento organizado" "33 vivendo às margens da sociedade. Nesse sentido, o pirata é colocado na posição de general para enfatizar a organização do seu bando, sua posição como líder capaz e de grande perspicácia, e a violência que impinge não apenas a Calírroe (a quem, aliás, também salva), mas à cidade de Hermócrates. É ela mesma quem chama a atenção para esse fato, ao declarar que seu pai, que antes vencera trezentos navios atenienses, nada fazia para socorrê-la depois de

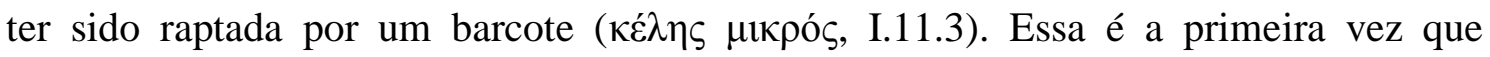
Cáriton coloca lado a lado a vitória sobre os atenienses e os eventos que se desenrolam na vida de Calírroe e de Quéreas.

Todavia, não é apenas uma inadequação de status que impede Téron de se apresentar como agressor sexual, uma possibilidade, aliás, que o autor tem em vista,

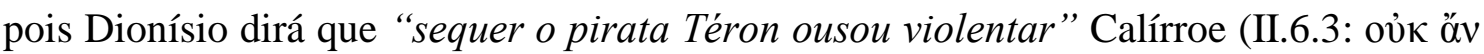

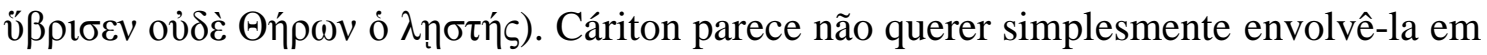
situações em que, por meio da violência, sua castidade é ameaçada e a sua fragilidade ressaltada, como acontece com outras heroínas do romance de amor. Seus pretendentes buscam a reciprocidade no desejo. Por três vezes os homens que se apaixonam por Calírroe mencionam a possibilidade de tomá-la à força, mas ou a descartam em seguida ou a violência não é dirigida especificamente a ela. Apaixonado por aquela que sabe ser a filha de Hermócrates, Dionísio afirma que não pode exercer tirania sobre uma mulher livre (II.6.3) e, ao refletir como poderia conquistá-la, recusa usar como meios ameaças e

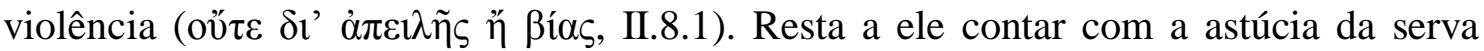
Plângon, a quem promete liberdade se ela ajudá-lo a alcançar seu objetivo. É também no poder de persuasão de seu eunuco que confia o Grande Rei, declarando que se tivesse intenção de satisfazer seu desejo "às claras e pela violência" (

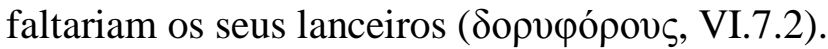

O único que admite a possibilidade de tomar Calírroe à força é Mitridates (IV.7.1-2) que, porém, não planeja apenas o seu rapto, mas o assassinato de Dionísio, a

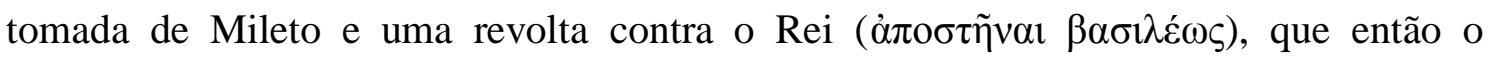

\footnotetext{
${ }^{33}$ Alvares (2001-2002, p.119).
} 
convocava a comparecer ao tribunal na Babilônia para ser julgado pelas acusações de Dionísio: "não desista das duas coisas que lhe são mais caras, o amor e o poder" (бù

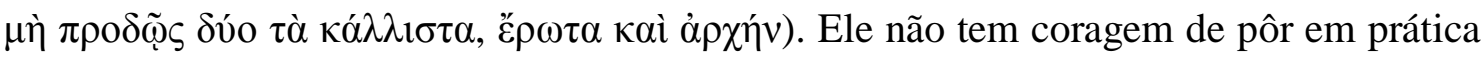
seus planos, mas é o único que imagina que o poder político lhe garantiria acesso a Calírroe. Porém, pouco antes da revolta egípcia, o narrador nos dá a conhecer que o Grande Rei quase teve de enfrentar outra insurreição, motivada principalmente pelo desejo erótico. Eros vai desestabilizando as estruturas políticas do reinado persa.

Percebe-se no plano de revolta de Mitridates que a associação entre guerra e a disputa por Calírroe projeta-se com o avançar do enredo em uma direção que assume feições cada vez mais concretas até culminar no episódio bélico da rebelião egípcia. Em uma passagem anterior, uma solução que envolvesse apenas os maridos de Calírroe é rejeitada pelo narrador. Quando Quéreas desembarca na Jônia em busca da esposa e descobre que ela está casada com outro homem, sua atitude não poderia ser menos passiva. Ele se desmancha em lamentos e é mais uma vez consolado por Policarmo (III.6.6-8):

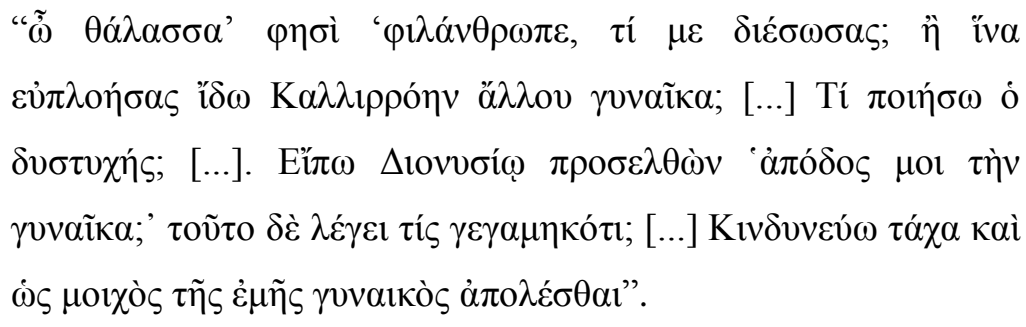

Logo depois que Quéreas é informado sobre o segundo casamento de Calírroe, Focas, o administrador da propriedade de Dionísio, observa uma trirreme de guerra

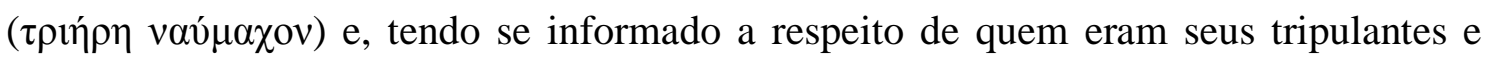
com que propósito chegavam a Mileto, procura evitar o pior e impedir uma guerra que, nas palavras do narrador, não seria nem grande nem de interesse geral, mas diria

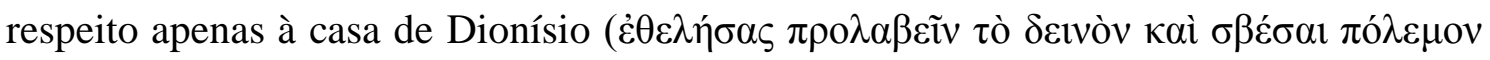




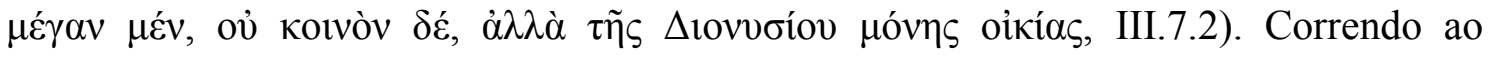
encontro de uma guarnição persa, Focas informa a presença de uma trirreme inimiga, sugerindo a possibilidade de uma guerra ou de um assalto de piratas, e ela é então atacada e incendiada à noite, resultando na morte de alguns siracusanos e no aprisionamento de outros, entre os quais Quéreas e Policarmo.

A ironia aqui é que, enquanto Focas imagina uma situação de embate violento entre seu senhor e o primeiro marido de Calírroe, este há pouco não fazia outra coisa senão se lamentar pelas novas núpcias da esposa. Quéreas em nenhum momento do romance vislumbra a possibilidade de recuperá-la por meio da força. Quando o narrador fala mais uma vez em guerra entre os dois maridos (V.8.4), já na cena do tribunal na Babilônia, o respeito pela presença do rei é o que impede que eles resolvam seu problema no braço, embora a imagem sirva para enfatizar o início de uma mudança de disposição de Quéreas, que pela primeira vez enfrenta com palavras um rival, sinalizando o começo do seu amadurecimento. Porém, se na democrática Siracusa, é o povo que consegue Calírroe para Quéreas, no centro do poder persa, o destino da heroína continua a ser uma questão pública, mas agora nas mãos de um único juiz, algo que Quéreas aceita sem protesto.

Cáriton, desse modo, ao mesmo tempo que sugere desde o início que a rivalidade entre os pretendentes de Calírroe terminará em guerra, vale-se dessa imagem para colocá-la como objeto de contenda não de homens comuns, mas de uma disputa política, o que sugere que aquele que estiver com Calírroe é capaz de ser também um líder entre seus pares, algo de que Quéreas não havia até então dado qualquer sinal. Se os ex-pretendentes de sua esposa e Téron são apresentados como "generais" de uma guerra, Quéreas só será capaz de reconquistá-la quando ele próprio se tornar um. Ele retornará à Siracusa coberto de louros, levando a esposa, que todo o povo queria ver de volta à pátria, e com o tesouro persa que saqueia na Ilha de Arados, maravilhando seus conterrâneos que têm a oportunidade de ver "o saque dos persas em tempos de paz"

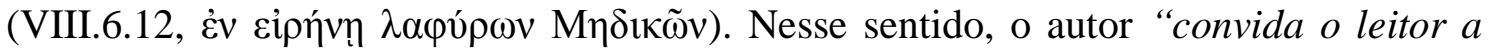
imaginar Calírroe como um objeto de valor infinito [...] Ora ela é Helena, ora ela é por metonímia a Sicília que Quéreas, um novo Hermócrates, deve tomar das mãos do predador estrangeiro" (Guez, 2001, p.106). Não bastaria o amor recíproco, despertado à primeira vista, para ser digno de estar ao seu lado? A narrativa parece sugerir que não, moldando-se o comportamento de Quéreas no desenrolar dos acontecimentos a ideais de masculinidade que o tornam mais ajustado à posição que ocupa. 


\section{II.4 A Guerra de Quéreas}

Com o início da guerra, nenhum dos personagens fica indiferente a respeito do destino que se dará a Calírroe (VI.9). Dionísio tinha esperança de recebê-la do rei como

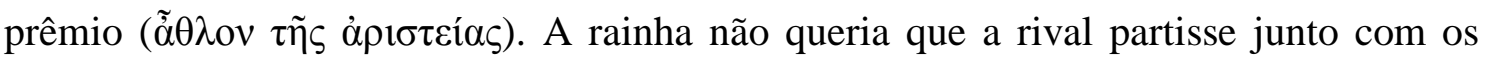
persas e, por isso, decide simplesmente não perguntar ao rei o que fazer com ela. $\mathrm{O}$ eunuco Artaxartes, que então a considerava um animal selvagem ( $\alpha \gamma \rho$ iòv $\theta \eta ́ p ı v)$ por se recusar a se dobrar à vontade do rei, sentiu-se aliviado: "parece-me que é um favor que venha a ser quebrado por uma guerra o desejo do rei, que estava sendo alimentado pelo ócio". 34

O rei, porém, mesmo no meio dos preparativos para a guerra, não havia se esquecido de Calírroe. O narrador informa que os persas tinham como costume levar, ao partir para a guerra, "as mulheres e os filhos, ouro, prata, roupas, eunucos, concubinas, cães, mesas, tesouros suntuosos e outros luxos" (VI.9.6); dessa vez Artaxerxes decide levar também a filha de Hermócrates. Porém, o eunuco estava certo; embora o sentimento por Calírroe não deixe de existir, a guerra permite que o rei se centre novamente nas suas funções políticas, que então estavam comprometidas por causa de sua paixão. Antes de saber que Calírroe não estava mais sob seu poder, ele até mesmo declara a Dionísio que lhe entregaria a mulher como prêmio (VII.5.15), por sua atuação na derrota da infantaria dos egípcios, demonstrando ter conseguido, enfim, controlar o seu desejo.

Quéreas, por sua vez, é, nas palavras do narrador, "o único homem livre na

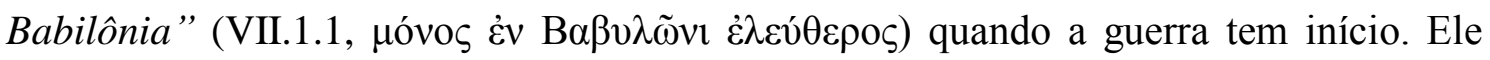
não precisa se juntar ao rei no combate e, por ser grego, imagina que Calírroe seria deixada na cidade, tendo esperanças de poder, enfim, recuperá-la. Quéreas logo é informado, porém, por um persa instruído por Dionísio a mentir, que não só sua esposa também havia partido, como o rei lhe entregara ao segundo marido, esperando que ele pudesse demonstrar sua gratidão no campo de batalha. Quéreas revolta-se porque o rei

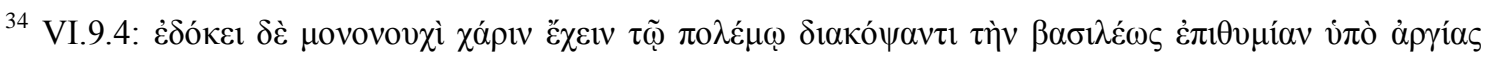
$\tau \rho \varepsilon \varphi о \mu \varepsilon ́ v \eta \nu$.
} 


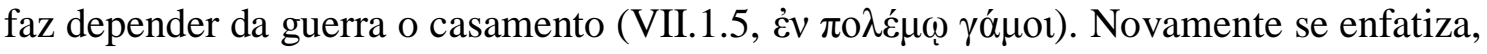
na sequência, que o herói não tinha qualquer disposição de agir de modo agressivo para retomar sua esposa, mas esperava persuadir com palavras o Grande Rei de que era ele quem merecia ficar com ela. O protesto pode soar irônico, porque é mesmo a guerra que decidirá com quem Calírroe vai ficar, mas para Quéreas, o julgamento era, de fato, a solução apropriada, mesmo que isso significasse aceitar que o Grande Rei tinha poder de decisão sobre o seu destino. À disputa por palavras deve-se somar o combate armado no processo de amadurecimento do personagem.

Logo depois de juntar-se ao exército egípcio, o valor de Quéreas para a armada torna-se evidente, não apenas pela sua rivalidade com o rei persa, pois o narrador diz que ele demonstrava resolução, coragem e lealdade, coisas condizentes com a sua natureza e educação. ${ }^{35}$ Seu desejo era mostrar que não era de se desprezar, mas, ao

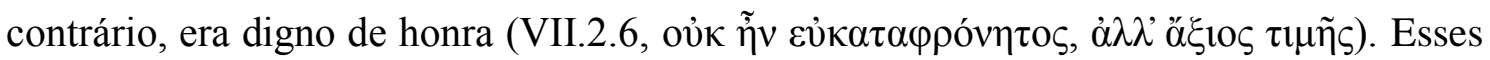
aspectos positivos enfatizados pelo narrador também são percebidos pelos personagens com que o herói interage. O fato de Quéreas não ter ficado no comando da infantaria,

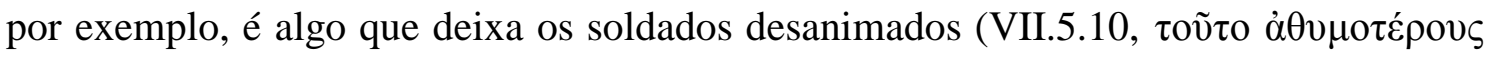

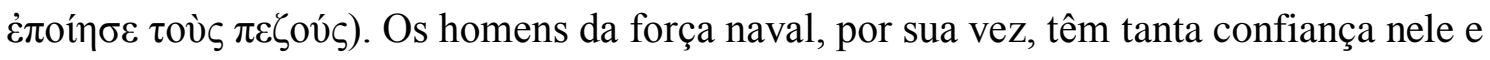
tanto o admiram que chegam a competir entre si para lhe provar qual deles era o mais determinado: "A armada [...] criou expectativas e encheu-se de orgulho, porque tinha

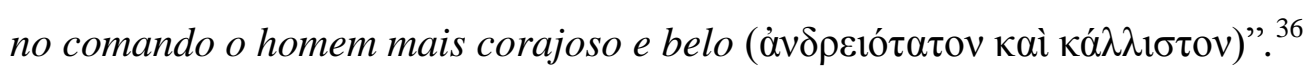

Antes da guerra, porém, a impressão que o personagem causava era ambígua. Embora tenha sido o povo de Siracusa a pedir a Hermócrates que desse a mão de sua filha a Quéreas, os pretendentes de Calírroe quando reclamam da falta de atitude do herói talvez indiquem uma reação que pode também ter sido a do público leitor: "que nos tenham preterido por aquele que em nada se esforçou pelo casamento é um ultraje que eu não tolero", ${ }^{37}$ No que diz respeito à violência sofrida por Calírroe, embora ela própria não demonstre em nenhum momento ter raiva dele por causa disso, ${ }^{38}$ não são

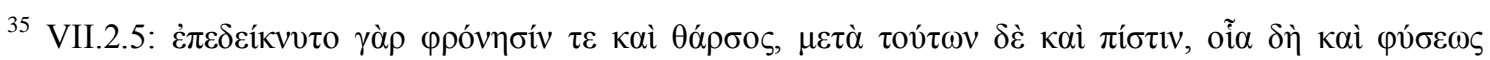

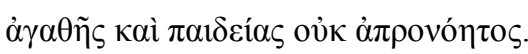

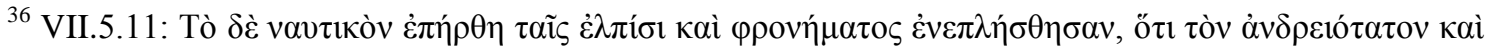

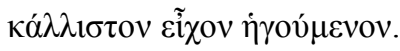

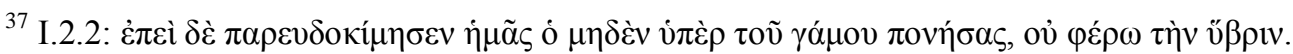

${ }^{38}$ Scourfield (2003) também analisa a ausência de raiva por Quéreas em Calírroe e conclui que isso está de acordo com a caracterização de uma mulher ideal e em controle de suas emoções. Cf. VI.5.8.
} 
todos que consideram Quéreas isento de culpa, como o julga o próprio Hermócrates. Ele mesmo afirma na carta que escreve a Calírroe que já cumpriu sua pena pelo que havia feito ao ser vendido, escravizado e preso. ${ }^{39} \mathrm{Nem}$ todos, contudo, consideram que a redenção esteja completa nesse momento.

Na Babilônia, o povo discute com qual dos dois maridos Calírroe deveria ficar; aqueles favoráveis a Quéreas argumentam que ela poderia voltar à pátria e rever sua família, observam que o amor entre eles era mútuo e que, além disso, Dionísio não poderia ter comprado uma mulher livre. Já os homens favoráveis a Dionísio lembram

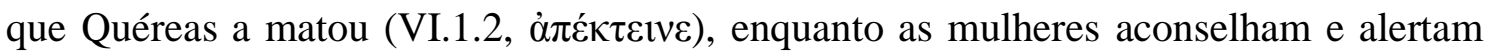

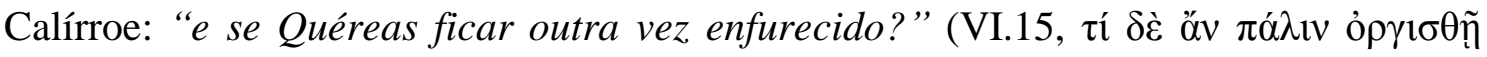
Xaıı́́as;). A avaliação negativa do herói é relevante porque, como Kaimio (1996, p. 59) pondera, o povo na Babilônia cumpre a função de leitor implícito do romance antecipando as diversas reações que o autor esperava que se tivesse ao enredo. Em virtude da caracterização positiva de Dionísio, talvez não fossem poucos os seus partidários. ${ }^{40}$ Assim, na troca de farpas que Dionísio tem com Quéreas no tribunal, ele encerra suas acusações chamando-o de "assassino" (V.8.6, poveṽ). E mesmo Calírroe, em trecho já citado neste capítulo (VI.7.9-10), quando quer argumentar ao eunuco Artaxates que Quéreas tem o seu valor, recorre à glória coletiva da cidade de Siracusa por ter derrotado os atenienses, e não a algo que ele próprio tenha realizado. É, portanto, graças à guerra que travam Pérsia e Egito que o herói pode, finalmente, provar o seu valor.

De início, a reação de Quéreas, ao acreditar ter perdido em definitivo sua esposa, é mais uma vez pensar em suicídio, como ele já havia feito diversas vezes. Dessa vez, porém, Policarmo não vê motivo para tentar dissuadi-lo e, pelo contrário, afirma que também se matará, mas sugere que eles o façam de uma forma que possa atingir o rei. Quéreas não percebe como isso seria possível e é então que Policarmo observa que a guerra permitiria uma vingança (VII.1.11):

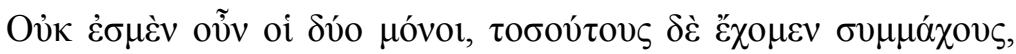

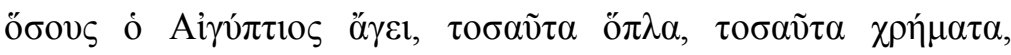

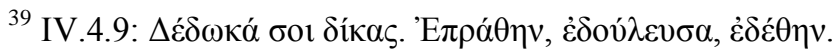

${ }^{40}$ Jones (2012, especialmente p.46-67) faz uma boa análise do personagem e chega à conclusão que ele é tão herói do romance quanto Quéreas.
} 


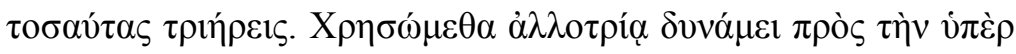
$\dot{\varepsilon} \alpha v \tau \tilde{\omega} v \not \check{\alpha} \mu v v \alpha \nu$

Não somos, então, apenas nós dois, mas temos tantos aliados quanto os que o Egito conduz, e as mesmas armas, os mesmos recursos, as mesmas trirremes. Utilizaremos a força alheia para a nossa própria vingança!

Para atingir seu objetivo, Quéreas e Policarmo misturam-se primeiramente ao exército persa para atravessar o Eufrates. Quando chegam à Síria, eles desertam para o lado egípcio, apresentando-se ao monarca eleito (que permanece anônimo durante todo episódio) como membros da aristocracia siracusana. Quéreas afirma ser genro de Hermócrates e essa é a credencial de que necessitam para serem aceitos no exército. Nesse momento, o rei egípcio havia assumido o controle da Celesíria (nome da região a oeste do Eufrates) e da Fenícia, com exceção da cidade de Tiro. O rei egípcio vê a cidade como um obstáculo intransponível, que impediria o avanço da força egípcia, e seu discurso tem um tom bastante conformado (VII.3.2). É então que Quéreas se opõe ao que é proposto e se oferece para enfrentar os tírios à frente de alguns homens. O rei permite que ele selecione aqueles que quisesse; Quéreas descobre vários mercenários gregos e escolhe trezentos entre lacedemônios, coríntios e peloponésios (todos de origem dória, como ele). A tomada dessa cidade é o primeiro grande feito de Quéreas na guerra, que o torna comparável a Alexandre. No seu discurso antes de partirem à ação, ele menciona os gregos que resistiram à invasão de Xerxes nas Termópilas (VII.3.9). Em seguida, sugere que os homens escolham um comandante, dispondo-se a segui-lo, sendo ele próprio então eleito democraticamente.

Quéreas na sequência mostra saber vencer não pela força ou pela superioridade numérica, mas pela estratégia; nada mais grego. Era historicamente difícil tomar a cidade de Tiro porque ela estava localizada, originalmente, numa ilha próxima da costa, rodeada por muralhas. É Alexandre, o Grande, quem sitia a cidade por sete meses em 332 a.C. e constrói uma ponte terrestre artificial para ligá-la ao continente, mas Cáriton ignora esse detalhe. No romance, a cidade de Tiro não fica em uma ilha, mas em uma extensão de terra ligada ao continente apenas por uma estreita faixa. Em razão dessa descrição, acredita-se que Cáriton possa ter usado como fonte o relato da tomada de 
Tiro em $O$ Romance de Alexandre $(1.35) .{ }^{41}$ No entanto, Hilton $(2005$, p. 63) pondera que Cáriton não teria seguido esse relato específico sem nenhum propósito em mente: "a mudança dá mais ênfase ao papel heroico de Quéreas ao capturar a cidade com um pequeno contingente do que a complexidade técnica da construção de uma ponte até a cidade e os esforços dos tírios para frustrar sua construção”.

A tomada da cidade de Tiro só ocorre porque Quéreas finge comandar um grupo de gregos mercenários, insatisfeitos com a falta de pagamento da parte dos egípcios; assim, as portas se abrem para eles, que dominam a cidade. A confusão entre os homens que tentavam voltar para o interior da cidade e os que buscavam sair dela para descobrir o que estava acontecendo tornava fácil aos gregos a tarefa de liquidá-los. No fim, os homens de Quéreas acabam tirando proveito daquilo mesmo que dificultava o acesso à cidade. O narrador afirma, então, que ele era o único a se manter sob controle (VIII.4.9,

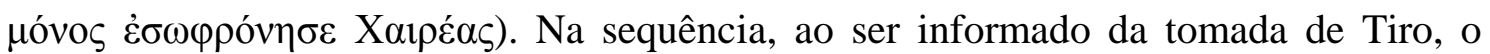
Grande Rei decide deixar a rainha e o tesouro na ilha de Arado ${ }^{42}$ para avançar mais rapidamente contra o inimigo.

O rei egípcio, por sua vez, convida Quéreas a escolher quais forças gostaria de comandar, sugerindo, entretanto, que ele optasse pela naval, uma vez que os siracusanos haviam vencido no mar os Atenienses (que antes haviam derrotado os persas). E

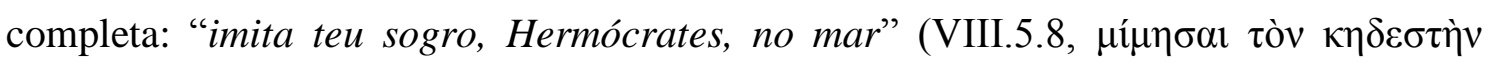

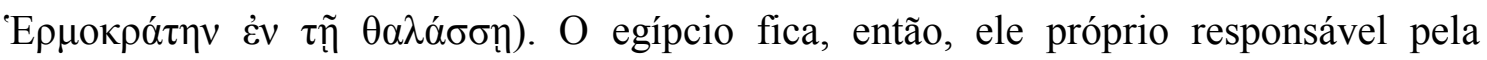
infantaria, que trava com os persas uma longa batalha, na qual a vantagem numérica dos últimos é decisiva. Dionísio pede ao Grande Rei o comando de cinco mil homens e faz com eles um ataque noturno; o monarca egípcio é capturado e suicida-se em seguida. Enquanto isso, Quéreas não enfrenta nenhuma resistência para vencer os navios persas e, ainda sem saber da derrota das forças terrestres, toma Arado, onde reencontra Calírroe.

É relevante o fato de que a excelência de Quéreas como comandante passa a ser construída por meio de alusões à historiografia grega ${ }^{43}$ e à épica, ${ }^{44}$ ao passo que antes o

\footnotetext{
${ }^{41}$ Relatos sobre o cerco de Alexandre a Tiro: Arriano, 2.15.6-2.24.5; Plutarco, Alexandre 24-25 e Cúrcio, 4.2.1-4.4.21.

${ }^{42}$ Sobre a presença da ilha no romance, cf. Sébasti, 2005.

${ }^{43}$ Cf. VII.3.11 (Heródoto, I.82 e VII.186); VII.3.9 (Tucídides, II.37.1) e VII.4.9 (Xen., Ciropedia, 7.1.32).

${ }^{44}$ Cf. VII.2.4 (Ilíada, XXII.304ss); VII.3.5 (Ilíada, IX.48s); VII.4.3 (Ilíada, XIII.131); VII.4.6 (Ilíada, X.483).
} 
narrador privilegiava nas suas citações versos que diziam respeito à amizade entre Pátroclo e Aquiles como paralelo às relações eróticas que se desenvolvem no texto. Que a conduta de Quéreas será próxima a dos heróis da épica é algo que fica claro logo de início; Policarmo, ao sugerir que se juntem ao exército egípcio, afirma que (VII.1.8-9):

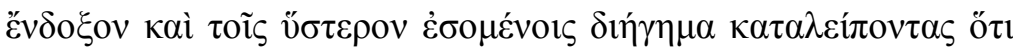

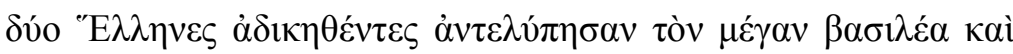
$\dot{\alpha} \pi \varepsilon \dot{\varepsilon} \theta \alpha v \sigma v \dot{\omega} \varsigma \alpha ̋ \delta \delta \rho \varepsilon$.
}

Seria notável se deixássemos aos vindouros a história de dois gregos que, injustiçados, deram o troco no grande rei e morreram como homens.

Aí temos uma clara evocação da busca do herói épico pelo kléos, que sabemos não ser só a glória do herói, mas também da poesia que o imortaliza, adaptada ao contexto romanesco. O herói quer se vingar, sim, daquele que o tratou com injustiça, mas também quer deixar algo que passará à posteridade: um diégema, uma narrativa, uma história. Essa relação com o herói épico é reforçada algumas linhas adiante, quando da boca de Quéreas saem ipsis litteris palavras ditas por Heitor na Ilíada, as últimas que ele pronuncia antes de entrar em combate com Aquiles (XXII.304-5 e VII.2.4):

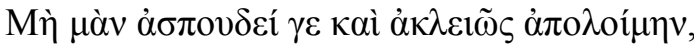

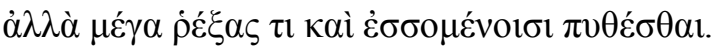

Não, que eu não morra sem luta, sem glória, mas após um grande feito que até os vindouros conhecerão.

Como nota Scourfield (2003, p. 174), combinados na decisão dos dois amigos de se juntar ao exército egípcio estão as ideias de prejudicar os inimigos, deixar um nome para a posteridade e ter uma morte honrada, elementos-chave do código heroico. No entanto, ainda que Quéreas busque a glória, sua atitude com relação a ela não é totalmente positiva. Após ser o responsável pela tomada de Tiro, Quéreas é o único que se recusa a comemorar a vitória; ao contrário, ele se pergunta "qual motivo para 
comemorar a vitória se você não está aqui para observar, Calírroe? Eu jamais voltarei a usar uma guirlanda, após a noite de nosso casamento". 45

A representação de Quéreas, que passa a partir desse momento a ter traços de heroicidade que podem ser considerados mais tradicionais, foi vista de início, porém, como incongruente, o que é discutido na seção seguinte deste capítulo.

\section{II.5 A Violência de Quéreas}

Para a ação de Quéreas na guerra, duas possíveis relações com eventos históricos foram apontadas. Recentemente, Bowie (2002), discutindo evidências que auxiliem na datação do romance, sugeriu que um personagem histórico, Cassius Chaerea (em grego

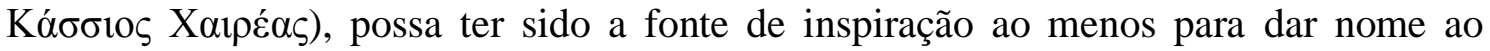
personagem. Como centurião, no ano de 14 d.C., ele teria sido um adulescens animi ferox, segundo Tácito. ${ }^{46}$ No ano de 41 d.C., quando já era um tribuno da guarda pretoriana, Cassius Chaerea teria assassinado o imperador Calígula pelos constantes insultos de conotação sexual dos quais era vítima. ${ }^{47}$ Bowie (idem, p. 55) acredita que, além do uso do nome na Comédia Nova, a repercussão do crime também tenha algo a ver com o nome dado por Cáriton a seu herói: "embora Quéreas seja um adulescens apaixonado, há mais aspectos em seu caráter [...], e os relacionados à propensão a ações violentas e à disposição para fazer carreira militar são mais bem explicados pela figura histórica de meados do século I de Cassius Chaerea". Apesar de ser significativo que um personagem histórico homônimo e de evidente importância tenha sido possivelmente contemporâneo do autor, esses aspectos do personagem Quéreas podem ser relacionados a outro personagem histórico.

Anteriormente, Perry (1967, p. 100, n. 11) havia apontado como inspiração na

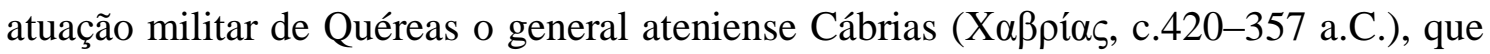
teria lutado ao lado do rei egípcio Tacos na revolta contra a Pérsia em 360 a.C. Como

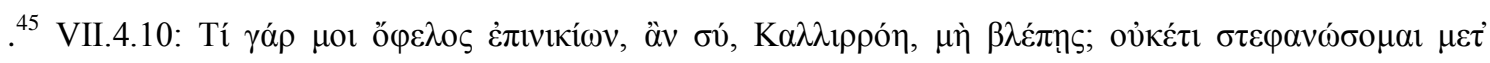

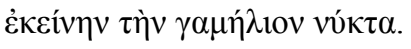

${ }^{46}$ Anais, 1.32: Cassius Chaerea, mox caede Gai Caesaris memoriam apud posteros adeptus, tum adulescens et animi ferox, inter obstantis et armatos ferro viam patefecit.

${ }^{47}$ Suetônio, Calígula, 56.
} 
Quéreas, Cábrias lidera a expedição naval ${ }^{48}$ e ambos lutam não porque foram enviados

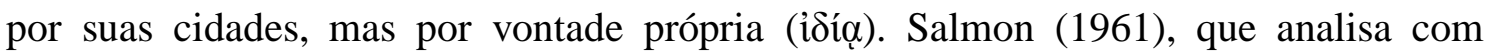
detalhe essa possível referência, observa também que a presença de vários gregos dórios mercenários no romance está de acordo com evidências históricas da revolta egípcia de 360 a.C. Tilg (2010, p. 48) sugere que a alteração do nome Cábrias para o nome Quéreas possa ser explicada pelo fato de a última forma ocorrer em peças de Menandro e nota ainda que Plutarco o caracteriza como "instável e excessivo" (Fócio, 6.1,

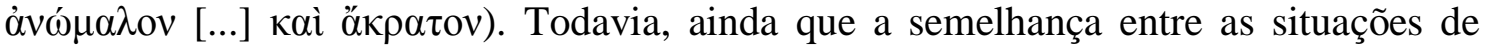
Quéreas e Cábrias seja clara e os nomes soem parecidos, havendo, portanto, a possibilidade de uma inspiração, não me parece razoável que Cáriton desejasse que os seus leitores identificassem seu herói, casado com aquela que é tantas vezes chamada de filha de Hermócrates, com um ateniense.

É verdade que a entrada em cena de um inimigo bárbaro, o rei persa, põe novamente Atenas em uma posição ambígua, ${ }^{49}$ pois a depender da perspectiva, a cidade ora é tirânica, ora é o símbolo máximo da democracia grega. Cáriton, porém, toma o cuidado de pôr em cena apenas gregos dórios para lutar ao lado do herói, reforçando a oposição entre Siracusa e Atenas. De qualquer forma, não nos é possível apontar Quéreas como um personagem histórico da cidade de Siracusa, o que indica que Cáriton não teve intenção de criar um herói identificável nos livros de história.

Sem modelos "reais" com que comparar o personagem, há que se tentar entender a caracterização complexa de Quéreas na economia do romance. Smith (2007) oferece uma interpretação audaciosa, a de que o personagem de Quéreas evocaria o ateniense Alcibíades, figura histórica cuja personalidade polêmica explicaria a caracterização intencionalmente contraditória do herói romanesco,${ }^{50}$ mas a meu ver o texto de Cáriton fornece poucos indícios para uma leitura como essa. Por outro lado, ainda que os críticos tenham reprovado o que consideraram uma mudança de personalidade súbita, a caracterização do herói não é de todo incoerente. Afinal, o "novo" Quéreas da narrativa da revolta egípcia surge porque a caracterização deixa por um momento de estar centrada em sua angústia e incapacidade de ação pela perda de Calírroe e encontra um

\footnotetext{
${ }^{48}$ Cf. Diorodo Sículo, XV.92.

49 A primeira vez é quando Téron decide partir para Jônia, sob domínio persa, julgando que seria mais fácil vender Calírroe, em vez de partir para Atenas, como sugeriam seus comparsas (I.11.5-6).

${ }^{50}$ No início da narrativa, Alcibíades é o único personagem histórico mencionado pelo narrador para ressaltar a beleza de Quéreas, ao lado de Aquiles, Nireu e Hipólito (I.1.3).
} 
novo foco na sua atuação militar. O que nos faz, na verdade, questionar se o fato de Eros no romance ser um sentimento avassalador é realmente algo que está de acordo com uma representação positiva da masculinidade do herói.

De fato, o retrato de Quéreas em boa parte do romance não o favorece diante do leitor: o suicídio parece ser a "reação instintiva" do herói quando colocado numa situação difícil. Um exemplo ilustrativo dessa personalidade se encontra no livro III, quando Quéreas está se preparando para partir de Siracusa em busca da esposa. Nesse momento, seus pais agarram-se a ele e suplicam para que não parta; ao ver a angústia dos pais, a reação de Quéreas é atirar-se ao mar, “desejando morrer para que pudesse escapar das opções ou não procurar por Calírroe ou causar dor aos seus pais [...] os marinheiros quase não conseguiram trazê-lo à tona". 51

As tendências suicidas de Quéreas diante de frustrações manifestam-se outras vezes ao longo do enredo. ${ }^{52}$ Em uma leitura do herói romanesco como sugerida por Konstan (1994), isso não significa que Quéreas não seja um herói corajoso, apenas que a coragem não é o meio principal pelo qual sua afeição por Calírroe é exibida. Ao contrário, são seu sofrimento e sua incapacidade de agir que são enfatizados, pois sua angústia diante da perda de Calírroe é prova do quanto ele a ama. Uma passagem do romance deixa isso bastante evidente, quando o narrador compara as atitudes de Quéreas e Policarmo. Submetidos à escravidão na propriedade de Mitridates, Quéreas pouco consegue fazer, pois "a fadiga, a falta de cuidados, as cadeias, mas, acima de

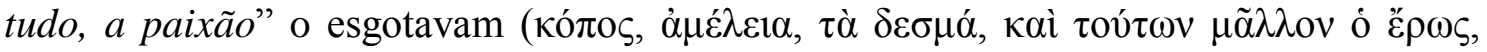
IV.2.1). Assim, Policarmo pedia para que se estabelecesse uma única área de trabalho para os dois e fazia praticamente o serviço de ambos (IV.2.3):

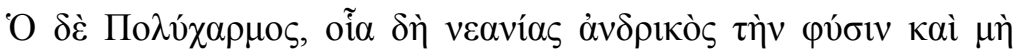

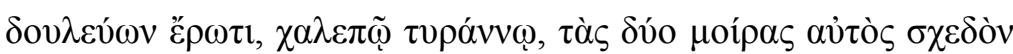

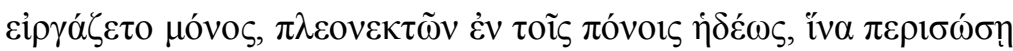

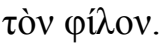

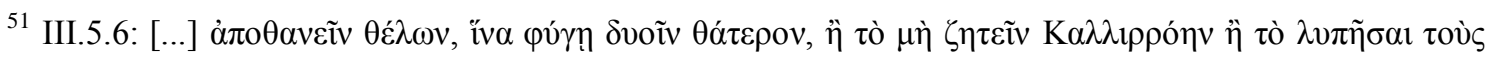

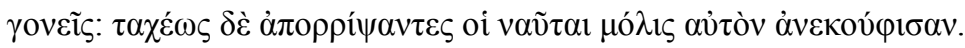

${ }^{52}$ Em todas as seguintes situações, Quéreas planeja seu suicídio: I.5, porque descobre a verdade sobre a suposta traição de Calírroe, que resultou na sua agressão e na sua morte aparente; em V.10, porque Calírroe não correra até ele no tribunal; em VI.2, porque o Grande Rei decide adiar sua decisão no julgamento entre ele e Dionísio; em VII.1, porque acredita que Calírroe foi dada a Dionísio.
} 
Policarmo, um jovem viril por natureza, e que não era escravizado pelo amor, que é um tirano severo, trabalhava quase sozinho nas partes dos dois; dizia, com prazer, que era sua a maior parte do trabalho, a fim de resguardar o amigo.

Por causa dessa caracterização inicial, a princípio o fato de Quéreas se revelar um líder militar capaz e seguro de si nos últimos livros do romance foi considerado uma alteração de personalidade que se julgou ser motivada por uma inabilidade do autor na construção de seus personagens. Essa é a opinião de Rohde (1876) e continua ser a de Helms (1966, p. 20-1) quase um século depois, que argumenta que a caracterização criada por Cáriton a partir de postulados retóricos resulta num sentimentalismo que hoje "transmite a impressão de uma fraqueza extrema". Ao tornar Quéreas "forte e corajoso, destemido da morte e vigoroso na ação", Cáriton teria realizado uma caracterização inconsistente e incomum no gênero. Essa percepção sobre o personagem começou a se alterar quando se passou a considerar que a mudança de caráter não é acidental, mas faz parte de um projeto do autor. A ideia de uma "educação do herói” no romance grego já havia sido introduzida por Perry em 1930, mas Schmeling foi o primeiro a sugerir, em $1974,{ }^{53}$ que a guerra configura um dos ritos de passagem que torna Quéreas digno de sua esposa e de seu sogro, expiando sua culpa diante da deusa Afrodite. De fato, o estranhamento causado pela mudança de comportamento é atenuado caso se pense num processo de aprendizagem, uma perspectiva assumida recentemente pela maioria dos críticos de Cáriton, seguindo a leitura de Balot (1998) de que é na guerra que o herói tem a oportunidade de preencher as expectativas do que se considera apropriado para um homem na sua posição social.

Mas o que, então, Quéreas aprenderia? O narrador revela pouco antes do reencontro dos amantes que os sofrimentos pelos quais o herói passa são resultado de uma punição de Afrodite pela maneira violenta com a qual havia tratado uma dádiva sua. Assim, sugeriu-se que esse período afastado da esposa ensina Quéreas a atitude adequada ao amante ideal: "ela requer lealdade a Calírroe, manifesta em uma confiança absoluta nas suas ações e no abandono do ciúme violento" (Alvares, 20012002, p.79). Morgan (1996), por sua vez, defende que se Afrodite estava tentando dar uma lição a Quéreas, ele não entende nada e continua ciumento no final do romance,

\footnotetext{
${ }^{53}$ Apud Smith (2007, p.19).
} 
não havendo, de fato, um aprendizado. É verdade que Calírroe se mostra receosa do ciúme de Quéreas após o reencontro em Arado (VIII.4.5), demonstrando que a "confiança absoluta" não é algo que passa a existir entre eles. Scourfield (2003), porém, parece fazer uma análise correta ao colocar não o ciúme, como Morgan, mas sim a raiva como principal elemento a estruturar a narrativa (Scourfield, idem, p.167):

\begin{abstract}
O ressentimento dos pretendentes provoca a raiva de Quéreas e a ação que isso ocasiona produz uma resposta irada de Afrodite. [...] Só quando sua raiva cessa, os eventos podem se direcionar para uma conclusão feliz. A raiva - humana e divina - estrutura, assim, quase toda a narrativa.
\end{abstract}

Desse modo, a mudança de Quéreas não diz respeito especificamente a forma como lida com sua esposa, mas a capacidade de controlar suas emoções, uma ideia que exploraremos com mais detalhe. Se imaginar que Calírroe esteve com outro é o suficiente para provocar uma agressão contra ela, tornando-a alvo de seu ódio, ao deixar a Babilônia para se juntar aos revoltosos egípcios, não é Calírroe nem sequer Dionísio o alvo de tal sentimento, mas o Grande Rei, a quem atribui injustiça no tratamento de seu caso (VII.1).

A falta de autocontrole (sophrosyne) de Quéreas é ainda ressaltada pelas citações de Homero que Cáriton incorpora à voz do narrador como se fossem palavras suas. A relação entre Quéreas e Calírroe é por cinco vezes aproximada daquela de Aquiles e Pátroclo por meio de versos da Ilíada repetidos pelo narrador ou pelos personagens. ${ }^{54}$ Isso é relevante porque, de certo modo, tanto Aquiles quanto Quéreas têm sua parte de responsabilidade na perda (definitiva ou temporária) dos seus amados. ${ }^{55}$

Os primeiros personagens, aliás, a sentirem raiva, na verdade, são os pretendentes, que, por essa razão, decidem agir contra o noivo escolhido. Ao perceberem que o ataque a Quéreas não poderia ser feito às claras, mas precisava ser

\footnotetext{
${ }^{54}$ Em I.4.6 e V.2.4, são citados os versos XVIII.22-24, que descrevem a reação de Aquiles à morte de Pátroclo. Em II.9.6 repetem-se os versos XXIII.66-67, de quando o espectro de Pátroclo aparece para Aquiles. Em IV.1.3, o verso é o XIII.71, quando o espectro de Pátroclo pede a Aquiles para sepultá-lo. Em V.10.9, é citado o XXII.389, de quando Aquiles diz que nem mesmo no Hades se esquecerá do amigo.

55 M. Morales e Mariscal (2003) discutem as citações que dizem respeito à relação entre Aquiles e Pátroclo em Cáriton e concluem que o autor a percebe como uma relação erótica.
} 
planejado com dolo, eles voltam-se a um estratagema que possa provocar o seu ciúme

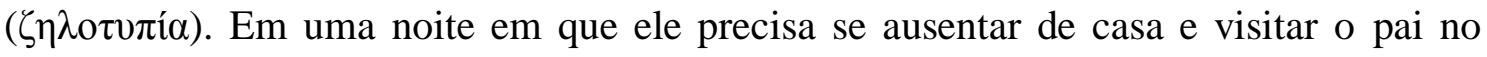
campo, que havia sofrido um acidente, Quéreas encontra vários sinais de que homens haviam estado à porta de sua casa cortejando sua esposa, o que o deixa fora de si, mas Calírroe consegue convencê-lo de que nada sabe do que se passou. Na segunda tentativa, um deles diz a Quéreas que sua esposa é infiel e sugere que ele busque provas da traição. Ele então informa Calírroe de que precisará ir ao campo mais uma vez e observa, do lado de fora, um homem entrar em sua casa, que havia para isso seduzido a serva de sua esposa. É o que basta para Quéreas comprovar suas suspeitas, mas a princípio o narrador informa que ele não tem intenção de punir a esposa. O trecho citado abaixo é parte do diálogo que Quéreas tem com o estranho que lhe diz que Calírroe é infiel pouco antes de observar o sedutor de sua serva adentrando a sua casa (I.4.7):

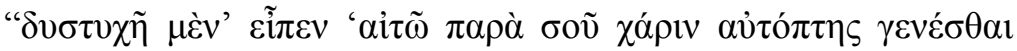

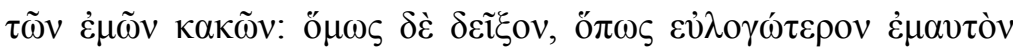

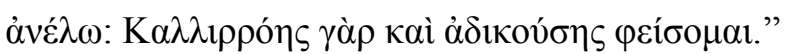

"Um triste favor eu te peço, que me tornes testemunha ocular dos meus próprios males. Mesmo assim me mostra, para que eu, tomando a melhor decisão, acabe comigo; pois Calírroe, ainda que tenha agido mal, vou poupá-la."

Essa declarada intenção de Quéreas de poupar a esposa é introduzida para dar ao golpe que desfere em Calírroe a impressão de falta de intenção (como Hermócrates dirá

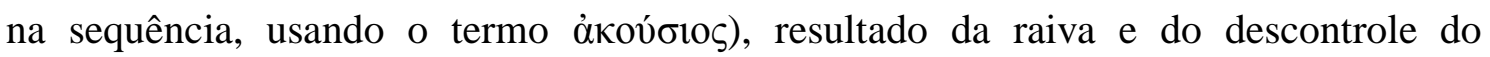
personagem no momento em que acredita ter confirmado a infidelidade da esposa. Ele corre para a casa para flagrar o suposto amante, mas este sai rapidamente e Quéreas só encontra Calírroe, que se lamentava no escuro (1.4.11-12):

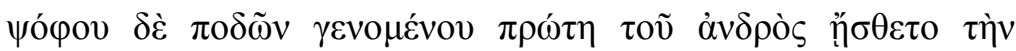

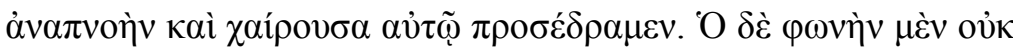

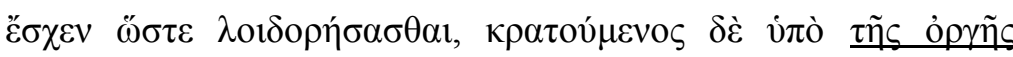
$\dot{\varepsilon} \lambda \alpha \dot{\alpha} \kappa \tau 1 \sigma \varepsilon \pi \rho \circ \sigma ı v ̃ \sigma \alpha v$. 
Ouviu-se um barulho de passos; logo ela reconheceu a respiração do marido e, feliz, correu até ele. Mas ele sequer teve voz para censurá-la e, dominado pela raiva, deu-lhe um pontapé quando ela se aproximou.

Scourfield (2003) observa que a raiva dos pretendentes e a de Quéreas parecem ser de naturezas distintas, porque a dos primeiros leva a uma ação planejada, enquanto a do último demonstra sua falta de controle emocional, mas o termo é o mesmo para os dois casos, $\grave{\eta}$ ỏ $\rho \gamma$. Isso é significativo no uso que se pode fazer do sentimento, como se discutirá na sequência. $\mathrm{O}$ narrador diz que os pretendentes sentiram um misto de dor e

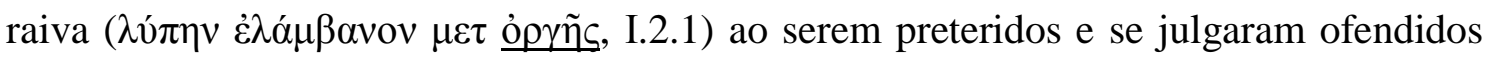

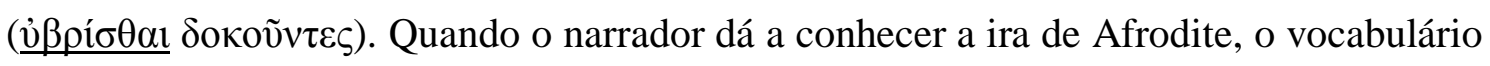
utilizado é semelhante (VIII.1.3). A deusa sentiu raiva (ỏ $\gamma 1 \sigma \theta \varepsilon i ̃ \sigma \alpha)$ de Quéreas por seu ciúme descabido e porque ofendeu, i.e., tratou com violência, a dádiva que havia

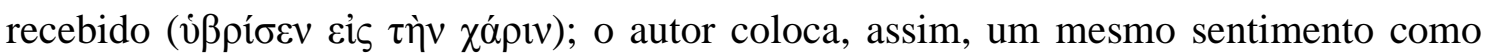
força-motriz dos acontecimentos na narrativa.

Já foram sugeridas algumas respostas sobre o que teria motivado Cáriton a conceber um herói romântico capaz de "assassinar" a própria esposa. Apontou-se, por exemplo, a influência de Perikeiromene de Menandro, ${ }^{56}$ mas na peça as consequências são muito menos sérias do que no romance. Outra possibilidade é a de um elemento histórico conhecido ter influenciado nessa ação: Hunter (1994, p. 1078), por exemplo, acredita que o chute possa estar relacionado ao fato relatado por Plutarco de que a filha do general Hermócrates teria cometido suicídio após ter sido violentada por rebeldes - e aí o elemento de violência permaneceria em sua narrativa, mas completamente reelaborado. Já se sugeriu também que a atitude de Quéreas só pode ser explicada por algum evento histórico com o qual os leitores da Antiguidade estivessem familiarizados, mas que a nós é hoje desconhecido. ${ }^{57}$ Ambas as explicações são plausíveis, mas é difícil

\footnotetext{
${ }^{56}$ Cf. Laplace (1980).

${ }^{57} \mathrm{O}$ único evento conhecido possivelmente contemporâneo a Cáriton que poderia ter inspirado o fato de que Quéreas chuta Calírroe é o rumor de que Nero teria provocado a morte de sua esposa grávida, Popeia, com um chute em 65 d.C. (Suetônio, Nero, 35.3). A maior parte dos críticos, no entanto, considera que Cáriton teria apenas se apropriado de um tópos literário, sem relação direta com os boatos sobre Nero. Cf. Tilg (2010, p.48-9).
} 
argumentar a favor delas; melhor é supor que Cáriton criou Quéreas como herói falível, ao menos na primeira parte do romance.

Por outro lado, Hunter também observa que o ato de chutar a esposa é encontrado diversas vezes em relatos historiográficos. ${ }^{58}$ Periandro, o tirano de Corinto, teria matado dessa forma sua esposa grávida, algo muito semelhante ao que ocorre no romance. Além disso, como observa Scourfield, "no pensamento político antigo, os tiranos eram comumente vistos como incapazes de controlar a si próprios".59 $\mathrm{O}$ narrador não apresenta Calírroe apenas como um dom de Afrodite, mas também como uma conquista do povo de Siracusa a Quéreas. Ele é duplamente presenteado, pela deusa e pela cidade. A raiva que sentem os pretendentes é, portanto, também uma resposta típica do comportamento de tiranos e a reação de Quéreas o aproxima deles. Se considerarmos o episódio no romance como adaptação desse tópos historiográfico, temos que questionar por que Cáriton quer aproximar Quéreas inicialmente do retrato de um tirano, por meio de sua raiva e descontrole.

Ao longo da narrativa, fica clara a importância dada ao autocontrole (sophrosyne), algo que é valorizado em todos os romances, sobretudo na esfera sexual, e a sophrosyne nessa forma literária está intrinsecamente relacionada à castidade. Hermócrates, porém, apresentado como um ideal a se emular, dá provas importantes do seu autocontrole em questões relacionadas a sua filha: em primeiro lugar, não atende ao pedido insistente de Quéreas de ser punido pela morte de Calírroe, mas é o primeiro a defendê-lo (I.5.6), declarando que ele havia agido de forma involuntária e responsabilizando os pretendentes pela conspiração. Em outra passagem, quando Téron confessa ter vendido Calírroe como escrava em Mileto (III.4.13-14), Quéreas não queria que ele fosse executado, pois desejava que ele revelasse quem tinha sido o comprador de sua esposa. Hermócrates interfere, porém, e condena a atitude do genro: "É melhor realizar uma busca com maior dificuldade do que infringir a lei" ( $\beta \varepsilon \lambda \tau i ́ o v ~ \pi o \emptyset \mid \sigma \alpha \sigma \theta \alpha \imath$

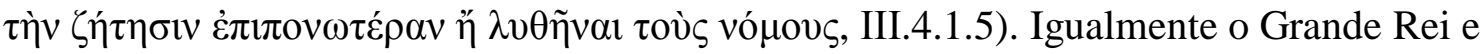
Dionísio dão grande importância à capacidade de autocontrole (II.4.4, VI.3.8), embora

\footnotetext{
${ }^{58}$ Hunter (idem, p.1080) enumera os seguintes testemunhos de fatos semelhantes atribuídos a tiranos: Periandro (Diog.Laert.1.94), Cambises (Hdt.3.32), Herodes Ático (Filóstrato, VS 2.1.8) e Nero (Tácito, Anais 16.6.1, Suetônio, Nero 35.3).

${ }^{59}$ Scourfield (2003, p.171, nota 39) enumera os seguintes exemplos relacionados à violência física: Hdt. 3.80.2-5; Thuc. 3.62.3; Pl. Resp. 9.571a-576b; Arist. Pol. 5.9.11-20 (1314b-1315b), esp. 5.9.17 (1315a14-16).
} 
ambos sejam derrotados quando se trata de resistir aos encantos de Calírroe, pois o amor é, no romance, uma força contra a qual é inútil lutar.

Scourfield (2003, p. 171) argumenta que, no fim das contas, não é o ciúme de Quéreas que é punido por Afrodite, mas que ele seria castigado essencialmente por ser ingrato a Afrodite. Essa leitura, considerada em conjunto com a defesa do genro que Hermócrates profere, faz o crítico sugerir que o narrador apresenta o ciúme de Quéreas como um atenuante do seu crime:

\footnotetext{
Longe de declarar ou sugerir que Quéreas deveria ter controlado suas emoções, se sugere que ele não as pôde evitar. Sem dúvida, é apropriado que ele sinta remorso, assim como é apropriado que Dionísio tente subjugar seu amor, mas nenhum dois é responsável por serem sobrepujados pela paixão.
}

Ainda que Scourfield considere que o problema de Quéreas é o fato de ele dirigir sua raiva à Calírroe, não aos conspiradores, ele também considera que o narrador, por meio das consequências desastrosas que esse descontrole tem na narrativa, deixa claro que o descontrole de Quéreas é avaliado de forma negativa. Além disso, é preciso considerar que ele é levado a agir por uma conspiração de tiranos e que a atitude de Hermócrates, mesmo que ele considere o assassinato algo involuntário, antes de absolver o ato do seu genro, demonstra o próprio autocontrole do personagem e sua inteligência política ao entender a estratégia dos ex-pretendentes da filha e ao convencer o povo de que Quéreas havia sido igualmente uma vítima. O contraste entre os dois personagens é evidente: Hermócrates não cede à dor, não deseja vingança e é capaz de subjugar suas emoções aos ditames da lei, quando Téron, o rapor da sua filha, é encontrado.

Essa falta de autocontrole de Quéreas me parece também estar presente na forma como ele lida com seus sentimentos por Calírroe, embora diversos críticos discordem. Como já se afirmou anteriormente, Konstan (1994) defendeu que as tendências suicidas e certa apatia de Quéreas que leva, entre outras coisas, à perda da trirreme siracusana e à sua redução à escravidão na Jônia são consequências de uma fraqueza provocada pelos sofrimentos da paixão; quanto mais ela é ressaltada, mais o herói parece entregue ao amor por Calírroe. Essa atitude não seria caracterizada negativamente, já que o amor é o valor máximo no romance. Com ele concorda Kaimio (1996, p. 54), para quem Quéreas 
não busca controlar suas emoções da forma como fazem Dionísio e o Grande Rei, mas sua submissão ao amor não seria caracterizada como algo reprovável e, sim, como demonstração da força irresistível de Eros e de Afrodite. Jones (2012, p.133-138) e Haynes (2003, p.92-3), por sua vez, consideram que o suicídio não é representado de forma negativa em Cáriton, bem como Lalanne (2006, p.114-115), para quem a ideia de morte autoprovocada faz parte do enfrentamento da morte característico da iniciação juvenil. Por causa de Calírroe, Quéreas pensa em ou tenta se matar nove vezes na narrativa e Dionísio, duas. ${ }^{60}$ Não podemos desconsiderar o fato, porém, de que Policarmo, que tantas vezes salva o amigo do suicídio, só desiste de contê-lo e decide até mesmo se juntar a ele quando a revolta egípcia tem início, por considerar apenas nesse momento que recuperar Calírroe é, de fato, impossível. Além disso, ele afirma que (VII.1.8-9) ambos deixariam à posteridade a história de dois gregos que se vingaram do

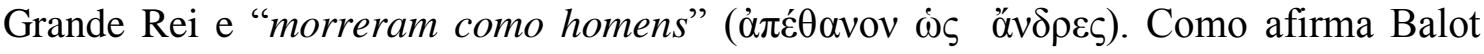
(1998, p.157), “ao entender a importância de 'morrer como um homem', Quéreas igualmente aprende a viver como um". A maneira como Policarmo formula a morte em batalha opõe-se, desse modo, à ideia do suicídio que perpassa toda a narrativa nos lamentos de Quéreas.

Assim, em Arado, vitorioso e confiante apesar de considerar Calírroe definitivamente perdida, Quéreas demonstra ter uma atitude mais segura também no que diz respeito às mulheres. Informado por um soldado sobre uma mulher entre as persas que ameaçava se matar e a quem o soldado havia sugerido que o próprio Quéreas a tomaria como esposa, este zomba da inabilidade do subordinado de lidar com as mulheres e até de si próprio (VII.6.12): "Pelo jeito sou mesmo atraente e sedutor, se antes de me ver ela já me rejeita e me odeia". ${ }^{61}$ Ele então pede que não a tratem com violência e levanta a possibilidade de ela estar em luto por um marido. Quéreas é incentivado por Policarmo a ir encontrar a cativa, que ainda não sabe ser a própria Calírroe, porque o amigo planeja que ele encontre um novo amor para consolá-lo pela perda da esposa (VIII.1.6), deixando totalmente de lado sua ideia inicial de que a morte seria uma resposta apropriada à entrega de Calírroe a Dionísio (inclusive para ele próprio, que tinha planejado morrer ao lado de Quéreas). A vitória na guerra provoca uma mudança de perspectiva. De modo semelhante, podemos observar uma alteração na

\footnotetext{
${ }^{60}$ Quéreas, I.4.7, I.5.2, I.6.1, III.3.1, III.5.6, V.10.10, VI.2.8, VI.2.11, VII.1.6 e Dionísio, II.6.2 e III.1.1.

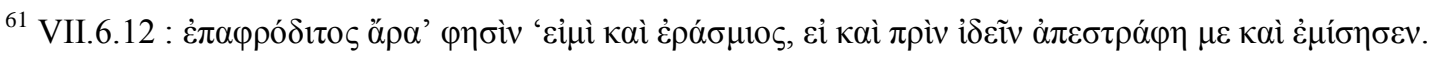


disposição de Dionísio. Calírroe diz a Estatira que tem medo de que ele se mate por ela ter voltado à Siracusa com Quéreas, mas ao ler sua carta (VIII.5.15), Dionísio se convence de que ela o havia deixado contra a vontade e decide criar o seu filho sozinho. Imediatamente antes, ele havia demonstrado total autocontrole diante do rei, quando informado da partida de Calírroe para a Grécia, porque a rainha havia se salvado e ele considerou inapropriado demonstrar sua dor (VIII.5.11). Esse reestabelecimento do autocontrole masculino faz parte do final feliz do romance que contrasta com a sugestão presente o tempo todo na narrativa de que Eros pode ser força negativa sobre o homem. Ao fim do romance, portanto, é preciso demonstrar que ele pode ser positivo, o que é concretizado nos conselhos importantes que Calírroe dá a Quéreas após a notícia da derrota do exército egípcio, discutidos na seção seguinte deste capítulo.

É verdade, no entanto, que todos os males que Quéreas sofre são colocados na conta de sua dívida com Afrodite. Já se observou que a menção à ira da deusa no início do livro VIII dá à narrativa um caráter épico, mas sua função vai além disso e estabelece como apropriados todos os sofrimentos pelos quais o herói passa. Porém, se é o desejo de morrer por não ter mais Calírroe que leva Quéreas à guerra em uma espécie de missão kamikaze e ao sucesso militar, nesse caso específico sua motivação suicida contrasta com sua forma de agir anteriormente (V.2.4-5), quando ele havia de forma

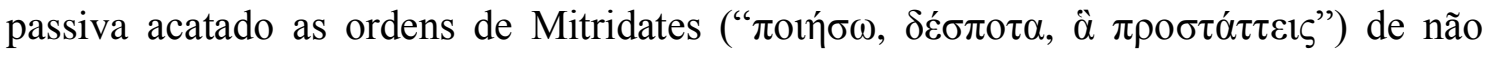

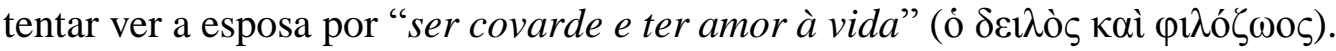

Um ponto importante é o fato de que o herói afirma ser a ỏpүí o que motiva a sua conduta em guerra (VIII.1.6), assim estabelecendo o mesmo sentimento que o leva a desferir um golpe contra Calírroe como aquele que o levou ao sucesso militar contra o rei persa. Porém, sua raiva dessa vez não é contra a esposa (e não é nem mesmo contra Dionísio), mas se dirige àquele que ele acredita ter tomado uma decisão num processo judicial sem sequer ouvir os argumentos dos envolvidos (VII.1.5). Trata-se de um Quéreas muito diferente daquele que, em vez de se voltar contra os ex-pretendentes conspiradores, agrediu Calírroe ao ser dominado pela raiva. Agora, pelo contrário, seu caráter irascível e seu desejo de vingança encontram na guerra o campo apropriado para se manifestar, ou seja, em um contexto em que há conflito entre iguais.

Que a raiva é impulso desejável e necessário para uma atuação militar excelente é algo observável na poesia épica, como van Wees demonstrou com relação a Homero (1992, p.61-165). Em contexto diferente, Braund e Gilbert (2003, p.270) evidenciam a importância da ira igualmente na poesia latina. O verso X.104 da Eneida, em que 
Virgílio afirma que os inimigos de Mezêncio não têm coragem de se aproximar, é analisado da seguinte forma por eles: "o verso define uirtus ('coragem', 'excelência', 'masculinidade') no contexto da batalha como dois fenômenos equivalentes ou mutuamente implicados: 'ficar com raiva' e 'aproximar-se', demonstrando que a ira é essencial para a uirtus do guerreiro, sobretudo para aqueles no combate mano a mano".

Em seu livro sobre a ideologia do controle da raiva na Antiguidade Clássica, Harris (2004) chega à conclusão de que, diferentemente do que ocorre com a esfera pública, pouco se pode dizer sobre esse tema quando restringimos o contexto ao ambiente familiar. ${ }^{62}$ No entanto, ele percebe em Sobre o Controle da Raiva de Plutarco (idem, p.311ss) um momento decisivo na história da ideologia do controle dessa emoção pelo fato do autor dar grande importância às relações familiares, ao passo que anteriormente a questão era vista quase exclusivamente por um viés político e cívico (Plutarco, Mor.462a-b):

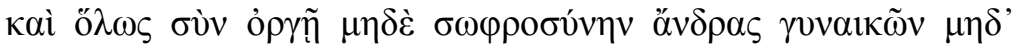

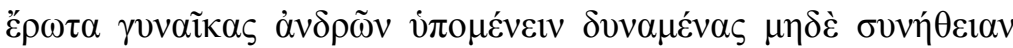

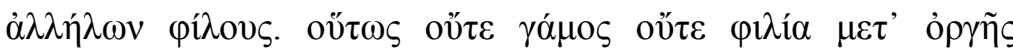

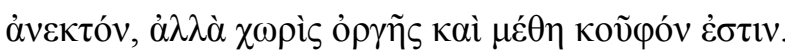

Em geral, se existe raiva, nem os homens são capazes de suportar a castidade de suas esposas, nem as mulheres o amor de seus maridos, nem os amigos a companhia uns dos outros. Portanto, nem a amizade nem o casamento são toleráveis se há raiva, mas sem raiva até a embriaguez é algo leve.

\footnotetext{
${ }^{62}$ Fischer (1998, p.71) sobre lei e violência na Atenas Clássica: "Rather less is heard explicitly of wifebeating as a regular practice, but it seems unlikely that it did not occur pretty routinely. It seems a plausible assumption that the relative reticence of the sources should be explained by ambiguities in the nature of male authority and women's nature; the standard ideological positions were probably that husbands should usually be able to persuade their wives to conform or obey, and that on the other hand women should not complain if failings were dealt with by physical punishment, provided it was not 'excessive"'.
} 
Faraone (2003), além disso, recentemente analisou diversas inscrições de

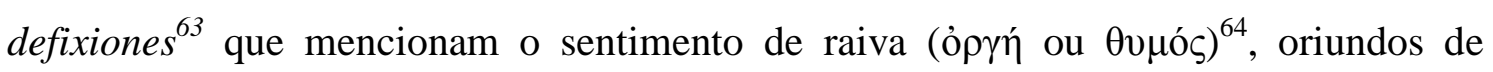
Chipre e de Atenas do século III d.C., além de fragmentos de manuais de magia do período imperial que registram thymokatocha (encantamentos para o controle do thymos). $\mathrm{O}$ autor argumenta que há uma manifestação da raiva (orgé) identificada com ideais de masculinidade e outra considerada patológica ou nociva. A partir dos defixiones, pode-se concluir que a orgé que é vista como positiva em um contexto de guerra na poesia épica é também considerada importante em outras situações competitivas entre homens, como o atletismo (havendo encantamentos contra a orgé de oponentes na luta e na corrida), a rivalidade amorosa e disputas judiciais. Nesse caso, o substantivo orgé significa algo próximo de "impulso natural”.

Uma segunda tradição, porém, dessa vez de amuletos, identifica o thymos ou a orgé como entidades patológicas que devem ser curadas ou extintas, indicando que se trata de algo excessivo. ${ }^{65}$ Se os defixiones analisados são empregados contra homens de mesma posição social em situações de competição, os amuletos, por sua vez, eram em geral utilizados por pessoas de situação inferior à daquela pessoa de quem pretendiam se proteger e, nesse caso específico, Faraone sugere que as fórmulas são utilizadas por esposas tentando acalmar ou "amarrar" a orgé de seus maridos (idem, p.162): "eram elas que nas sociedades tradicionais eram com frequência responsáveis pelos amuletos e poções curativas e que, no contexto doméstico ao menos, tinham mais a perder se fossem azaradas o suficiente para casar-se com homens de paixões violentas". Isso é significativo para o nosso romance, sobretudo porque o crítico aponta também a intrínseca relação existente entre a raiva e o desejo erótico (idem, p.161).

Não estou sugerindo com isso que Cáriton tematiza principalmente a violência doméstica no processo de aprendizagem de Quéreas, mesmo porque ao tentar restringir a orgé de seus maridos por meio de encantamentos, aparentemente o que se busca

\footnotetext{
${ }^{63}$ Defixiones são encantamentos mágicos inscritos em placas de metal com nomes de suas vítimas que eram geralmente dobrados ou enrolados, transpassados por um alfinete e enterrados em túmulos ou em poços.

${ }^{64}$ Aristóteles faz uma distinção entre a raiva concebida como orgé e outra, menos racional, chamada de thymos (Ética a Nicômaco, 1117a8), mas os termos seriam intercambiáveis a partir do período romano, cf. Faraone (op.cit., p.146s) e Harris (2004, p.50-70), sobre a terminologia em grego e latim.

${ }^{65}$ Sobre a percepção da raiva como uma espécie de doença na Antiguidade, cf. Harris (2004, p.339-400).
} 
controlar não é apenas a raiva. ${ }^{66}$ Porém, concordo com Balot (1998) que o romance de Cáriton é também sobre as qualidades necessárias de um bom marido. Uma orgé excessiva e descontrolada era percebida como algo negativo no contexto familiar e o sentimento só faz parte da construção de uma masculinidade idealizada quando dá ao homem a disposição necessária para enfrentar seus rivais. Nesse sentido, a conspiração dos ex-pretendentes de Calírroe da qual Quéreas sai como vítima pode ser considerada uma resposta muito mais apropriada à raiva suscitada pela sensação de desrespeito do que é a sua própria violência contra a esposa.

A excelência militar de Quéreas assinala uma mudança de atitude que representa o seu amadurecimento como homem adulto, algo necessário para ele recuperar Calírroe. No romance, porém, o valor marcial não é o que define a areté do herói, pois o que se espera é que o herói tenha aprendido uma lição para ambos os aspectos público e privado de sua vida, que parece dizer respeito ao controle das emoções. Pode-se considerar que, no nível metaliterário, o episódio bélico demonstra que o herói romanesco que "obedece a outro critério de areté", diferente da do herói épico, como observa Sousa e Silva, ${ }^{67}$ é capaz de incorporar os valores militares representados em outros gêneros, como reforçam as diversas alusões textuais a Homero e à historiografia clássica no episódio. Nessa relação de aproximação e oposição com a tradição literária, que Cáriton se preocupa em ressaltar ao longo da narrativa, o comportamento de Quéreas evidencia que, nem por ser diferente, sua areté é inferior à dos grandes heróis da história ou da épica, do qual o gênero romanesco é um herdeiro. A Dionísio, portanto, é dada a possibilidade de ter um desempenho semelhante ao de Quéreas na guerra porque o valor máximo no romance não é a glória que se deixará à posteridade, mas o amor. O sucesso de Quéreas em guerra é apenas uma etapa de sua vida que demonstra que agora ele poderá fazer jus à devoção de Calírroe por ele.

\footnotetext{
${ }^{66}$ Faraone (op.cit., p.162): "they are aiming at something more than his anger - something vitally connected with his individuality, his aggressiveness, and his autonomy, something that in a Mediterranean context such as this we might aptly call his machismo".

67 (1996, p.XIX): “Num gênero em que o happy end se tornou obrigatório, a paixão amorosa passou a funcionar como uma alavanca de salvação, o incentivo à resistência, ao reencontro e à felicidade. [...] Esta personagem romanesca obedece a outro critério de areté, caracterizado pela complexidade psicológica, onde avultam outras qualidades, como a delicadeza, a fragilidade, o amor à paz [...]”.
} 


\section{II.6 A história com final feliz}

A construção da excelência militar de Quéreas diz respeito principalmente à capacidade estratégica e de liderança dos gregos, ou seja, trata-se de algo além de um mero talento individual. Isso é ainda enfatizado com a escolha democrática tanto do rei egípcio quanto de Quéreas como comandante da expedição contra a cidade de Tiro. Assim, a forma como a mudança de disposição de Quéreas é narrada está também de acordo com o aspecto ideológico que se insinuava no enredo desde o início. Ao fazer o herói lutar ao lado dos egípcios e no comando de trezentos homens dórios, há uma tentativa de Cáriton de alinhar Quéreas numa luta política contra um estado opressor, reproduzindo em outro contexto a relação entre Siracusa e Atenas da forma como é descrita no romance. Ainda que, como diversos dos personagens, Quéreas tenha motivações eróticas para se envolver na guerra, ele só assume uma postura ofensiva no momento em que sua atuação não poderia mais ser entendida como a de um agressor, mas, pelo contrário, fortalece uma revolta contra um governo tirânico. Ao final da história, a Sicília representa um lugar para onde escapar da tirania ${ }^{68}$ e diversos dos subjugados à Pérsia escolhem a cidade como novo lar quando descobrem que a revolta egípcia havia sido contida.

Uma vez que reencontra Calírroe, porém, a rivalidade política é colocada em segundo plano e Quéreas logo se declara arrependido de ter lutado contra o Rei, quando a esposa lhe informa que ele não havia feito nada contra ela (VIII.1.16):

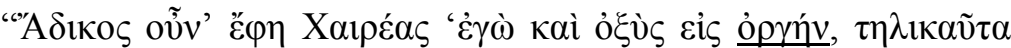

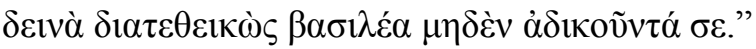

"Então eu fui injusto", disse Quéreas, "e também excessivo em minha raiva, por ter colocado o rei em uma situação tão terrível sem que ele tenha te feito nenhum mal".
}

A rapidez com que o personagem assume ter sido injusto com o rei persa é significativa (ainda que Quéreas tenha de ser dissuadido por Calírroe a tornar a rainha persa sua escrava) e vai refletir-se adiante, quando ele afirmar para o povo de Siracusa,

\footnotetext{
${ }^{68}$ Cf. Doody (1996, p.194).
} 
reunido no teatro, que conquistou para a cidade a amizade do rei ao devolver as mulheres persas (VIII.8.10). Por causa do estranhamento que essa mudança súbita de disposição provoca, buscou-se justificar a atitude de Quéreas. Uma tentativa é a tese de Laplace (1980, p. 61ss.), para quem o personagem não é apenas comparável a Alexandre por ter, como ele, tomado a cidade de Tiro, mas por ser magnânimo na relação que estabelece com os persas derrotados, emulando as atitudes do general macedônio. Assim, sua vitória não reforça o ódio, mas leva à substituição do ódio ancestral pela amizade, inaugurando um mundo "à imagem do sonho de Alexandre", construído literariamente com forte influência da Ciropédia de Xenofonte.

Todavia, a relação entre Siracusa e Pérsia já havia sido mencionada anteriormente como amigável, quando Dionísio afirma que o Grande Rei todo ano enviava presentes a Hermócrates para honrá-lo pela vitória contra os atenienses, um inimigo comum (II.6.3). E a própria caracterização do rei é positiva; seu desejo por Calírroe é apresentado como algo irresistível e, ainda que ele não seja capaz de controlá-lo, recusa-se a tê-la em seus braços por meio da coação. Além disso, o que causa a indignação de Quéreas no início do livro VII, quando ele acredita que sua esposa havia sido entregue a Dionísio, nunca chegou a acontecer. Se a guerra é o melhor juiz dos pretendentes de Calírroe, como se afirma duas vezes no romance (VII.5.15, na fala do rei em favor de Dionísio e VIII.4.2, na carta de Quéreas para o rei), o narrador parece sugerir que o envolvimento de Quéreas nela ocorre por um engano.

O que isso significa? Diversos críticos têm considerado as complexas relações políticas que se desenham no romance como, de alguma forma, manifestação pensada como resposta ao contexto histórico-social no qual Cáriton teria escrito sua obra, quando os gregos estavam sob domínio romano. ${ }^{69}$ Não se quer descartar a validade

\footnotetext{
${ }^{69}$ Para os críticos que adotam essa perspectiva, Roma está "tanto em nenhuma parte quanto em toda a parte" nos romances gregos, como bem observou Schwartz (2003, p.392). Um exemplo são os importantes estudos de Swain (1998) e Lalanne (2006), que interpretam o gênero como uma forma literária pela qual as elites gregas representam sua perpetuação por meio de casamentos exclusivamente gregos. Para Alvares (2001-2002), o romance representa um desejo de que os gregos pudessem, dada a sua excelência, de alguma forma negociar sua liberdade com os romanos. Smith (2007), estudando especificamente Quéreas e Calírroe, analisa as questões de tirania e democracia presentes no romance tendo em vista que elas seriam de especial interesse aos gregos subjugados ao poder romano. Schwartz (op.cit.), por sua vez, acredita que o império persa no romance deve ter chamado atenção dos membros da elite grega para alguns aspectos do poder romano, ou ao menos para uma percepção de si próprios como culturalmente superiores ao povo que o dominava. Concordo, porém, com as considerações de Tilg
} 
dessas hipóteses, mas o próprio desenvolvimento da narrativa justifica determinadas ações de seus protagonistas. Hunter (1994, p. 1061) interpreta, por exemplo, a recusa de Hermócrates de retardar punição a Téron como "manifestação poderosa do que é um dos principais temas da obra - a supremacia da lei sobre a desigualdade e a tirania". Relacionados a esse tema estariam dois outros, a supremacia dos gregos e da cultura grega sobre as bárbaras e a dos homens livres sobre os escravos e os de baixo status social. Esse conjunto de ideias que perpassa o romance contribui para a construção de um discurso que, como já se afirmou, pretende dar à narrativa um colorido histórico. Por outro lado, essa característica do romance faz com que os eventos e personagens localizem com certa acuidade os fatos do enredo e não permitem uma reescrita da história que crie situações descoladas do seu contexto "real". Revoltas egípcias foram diversas apenas no século IV a.C., ${ }^{70}$ o que justifica plenamente aquela de que Quéreas participa, mas a escravização da rainha e das mulheres da aristocracia persa em Siracusa não poderia senão levar a novos conflitos. Parece-me, no entanto, que essa forma de contornar um impasse narrativo é introduzida pelo rápido apaziguamento do ânimo de Quéreas para demonstrar que o herói sabe agora também o momento certo de interromper sua raiva, tendo em vista relações políticas mais positivas para sua cidade.

A devolução de Estatira permite ao narrador, por outro lado, ressaltar a generosidade de Calírroe e apresentá-la como conselheira indispensável a Quéreas, que parece não conseguir perceber as terríveis consequências que levar a rainha persa à Siracusa poderiam ter. Anteriormente, ela já havia impedido que o marido declarasse aos soldados que o rei egípcio havia sido capturado em combate, o que provocaria uma revolta dos prisioneiros do qual resultaria, provavelmente, na captura de todos os gregos. Mais do que demonstrar a sua inteligência e sensibilidade, o narrador procura enfatizar como os seus conselhos podem ser úteis a um homem que assume uma posição de liderança. Se ao longo da narrativa se insinuou o efeito negativo que o Amor pode ter sobre os homens e sua atuação política, é importante ressaltar no fim do romance que ele pode também ser positivo, em especial se a mulher ao lado do general

(2010) de que a relação extremamente cooperativa entre Afrodísias e Roma não parece corroborar tais interpretações. Parece-me interessante, no entanto, a sugestão de Schwartz (op.cit.) de que a representação positiva do tirano persa no romance pode ser justificada por ele ser a "autoridade masculina suprema" no seu reino. Demonizá-lo poderia chegar próximo de atacar as bases ideológicas do próprio império romano.

${ }^{70}$ Cf. Salmon (1961). 
for a filha de Hermócrates, de quem tenha herdado algo do tino político. Isso não significa que Quéreas é um tolo que depende de Calírroe para tomar as decisões acertadas porque, a partir da sua sugestão, ele rapidamente decide escrever ao Grande Rei exigindo a anistia para os revoltosos egípcios em troca da liberdade da rainha (VIII.4.3). ${ }^{71}$

Quéreas, então, mente ao declarar aos soldados a vitória da infantaria e, em seguida, ele ordena que zarpem de Arado em direção ao rei egípcio. Ele pede que os comandantes rumem para Chipre, onde desembarcam e fazem oferendas a Afrodite, que ali tinha um santuário. É só aí que Quéreas informa os seus aliados da derrota em terra do exército egípcio. Ele pergunta-lhes, na sequência, o que devem fazer e é um parente de Brásidas, o famoso general espartano, que sugere que naveguem em direção à Siracusa. Todos ficam animados, com exceção de Quéreas, que apenas finge não concordar para testar a resolução dos soldados. Vemos nessa passagem o herói utilizar o engodo sem hesitação e, como percebeu Smith (2007, p. 98), o comportamento de Quéreas nessa cena é um eco da tentativa de manipulação do exército feita por Agamêmnon no canto II da Ilíada, mas muito mais bem-sucedida do que a do chefe da armada grega em Troia.

Com efeito, parece haver três fases principais pelas quais a disputa por Calírroe passa ao longo do enredo e, ao final da história, Quéreas demonstra ter dominado os principais aspectos que as distinguem. Inicialmente, os ex-pretendentes da heroína valem-se do dolo e da manipulação dos fatos para separar o casal; na sequência, quando a disputa poderia se resolver por meio do discurso, no tribunal da Babilônia, o processo não chega a ser concluído, mas ele tem a chance de rivalizar verbalmente com Dionísio e sair-se relativamente bem; por fim, temos a decisão pela guerra e o que ela envolve, autocontrole, força, braveza e astúcia. A sequência dos eventos demonstra que, além de herói de guerra, Quéreas incorpora também a habilidade discursiva e a manipulação (utilizada, entretanto, de forma benéfica a todos os envolvidos). Não poderia haver par melhor para Calírroe.

\footnotetext{
71 Além disso, a reação de Calírroe, que fica chocada com a sugestão de levar a rainha persa como sua serva, demonstrando-lhe gratidão pela hospitalidade e proteção a ela reservada durante a guerra, altera o foco das relações entre gregos e persas, que deixa de ser uma rivalidade política e passa a ser a de uma amizade pessoal entre a rainha e Calírroe. “Também tu vais recuperar o teu marido” (VIII.3.8), diz a siracusana à rainha persa. No último livro, afirma o narrador, o leitor poderá se alegrar com "amores justos e casamentos legítimos" (VIII.1.4), no plural.
} 
Quando o casal finalmente retorna à pátria, os siracusanos a princípio suspeitam que os atenienses possam estar preparando novo ataque, mas os gregos fingem ser mercadores egípcios para atracar na cidade. Logo, porém, revelam-se à multidão Calírroe, em leito de ouro, e Quéreas, com as insígnias de general (VIII.6.7). Seu retorno é então comparado ao dia da vitória sobre os atenienses (VIII.6.10):

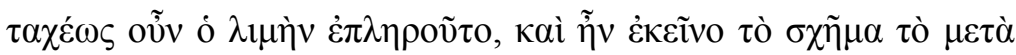

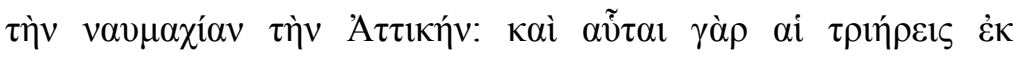

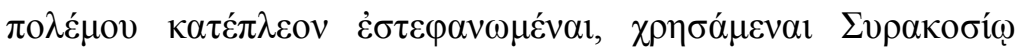
$\sigma \tau \rho \alpha \tau \eta \tilde{\tilde{\omega}}$.

Rapidamente o porto se encheu e tinha o mesmo aspecto do dia após a batalha naval contra Atenas, pois também essas trirremes voltavam da guerra vitoriosas, sob o comando de um general siracusano.

A glória de Quéreas é a glória da cidade. A multidão pede para que todos se dirijam à assembleia, para que possam ouvir o relato do que se passou. $\mathrm{O}$ povo reunido no teatro é só aplausos para o casal, mas Calírroe se retira para descansar e a tarefa de contar tudo o que aconteceu desde a partida de Siracusa fica para Quéreas, a "estrela em ascensão" no cenário político da cidade. Ele começa, no entanto, pelo fim, hesitando em contar as tristezas pelas quais passou inicialmente. É aí que Hermócrates intervém decisivamente (VIII.7.4):

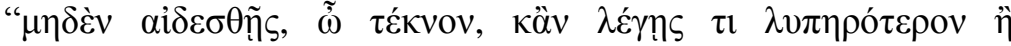

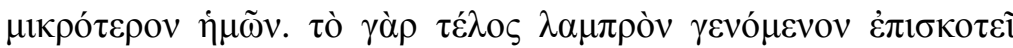

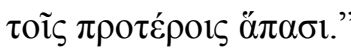
"Não te envergonhes de nada, meu filho, se contares algo mais doloroso ou indigno de nós, pois havendo final feliz, ele ofusca todos os fatos passados."

Essa passagem diz respeito ao próprio enredo do romance de amor. Prestes a narrar as aventuras que ele e a esposa viveram para o povo siracusano, Quéreas torna-se um duplo do narrador. Não importam o rapto por piratas e o segundo casamento de 
Calírroe, nem a redução de Quéreas e de Policarmo a escravos de Mitridates ou as angústias vividas na Babilônia. $^{72} \mathrm{O}$ romance caminha para um final feliz ( $\tau \varepsilon ́ \lambda o \varsigma$ $\lambda \alpha \mu \pi \rho o ́ v)$ capaz de redimir todos os males e as faltas dos heróis. Essa estrutura convencional do romance de amor, observável nos cinco exemplares supérstites que possuímos, leva a uma seleção de fatos no enredo, principalmente no caso de um bem localizado no tempo e no espaço como o do romance de Cáriton, que busca ofuscar a continuidade histórica dos eventos. Ora, já se demonstrou como o autor opta por uma caracterização quase mítica de Hermócrates, que ignora seu posterior exílio de Siracusa e sua tentativa de golpe.

No relato feito por Quéreas, ele não deixará de mencionar (VIII.7.12) o filho que ele e Calírroe geraram e que ela deixou em Mileto, um cidadão siracusano que ficou aos cuidados de um homem de prestígio ( $\dot{v} \pi \dot{\alpha} v \delta \rho o ̀ \varsigma ~ \varepsilon ̇ v \delta o ́ \xi o v)$. Na carta que Calírroe havia escrito ao seu segundo marido, e que Estatira fica encarregada de entregar, ela havia pedido (VIII.4.5-6) que, quando adulto, Dionísio o enviasse a Siracusa para conhecer o avô Hermócrates. Há muito se sugeriu uma identificação dessa criança com o futuro tirano Dionísio I de Siracusa que, segundo Plutarco, teria se casado com a filha do general siracusano. ${ }^{73}$ Embora, para considerar tal identificação, seja necessário dar conta das diversas mudanças que Cáriton introduziria nos eventos históricos (a esposa se torna mãe), tendo a concordar com Connors (2002, p. 17) que "em contraste com a visão típica de Dionísio como um tirano ruim (Diod.Sic.14.2; Cic.Tusc.5.57-63), o fato de Cáriton imaginar de modo otimista a chegada do filho de Calírroe a Siracusa apresenta um retrato geral mais venturoso do futuro do tirano”. Finais felizes talvez não sejam exclusivamente possíveis na ficção, mas no romance grego são obrigatórios. Na narrativa criada por Cáriton de Afrodísias, a felicidade do casal precisa também ser a garantia da bem-aventurança da cidade.

\footnotetext{
${ }^{72}$ Embora o relato de Quéreas não coincida exatamente com o que aconteceu. Cf. Temmerman (2009) para uma análise completa dos discursos de Quéreas na parte final da narrativa, que demonstram que um aspecto importante do amadurecimento do personagem é a sua capacidade de manipulação dos fatos e o controle sobre outras pessoas. Isso inclui distorcer fatos que possam ser constrangedores para ele ou para Calírroe.

${ }^{73}$ Naber (1901) apud Smith (2007, p.246). Contra, Tilg (2010, p.46).
} 


\title{
TERCEIRO CAPÍTULO
}

\section{Dáfnis e Cloé: A Lição de Pã Stratiótes}

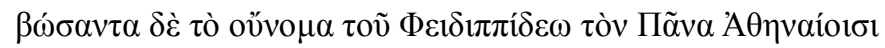

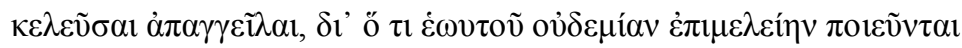

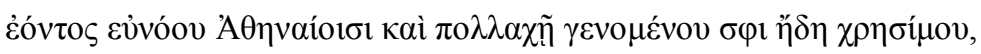

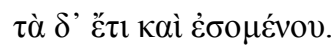

Chamando Fidípides pelo nome, Pã ordenou que perguntasse aos atenienses por que nenhuma atenção lhe davam, uma vez que ele era bem-disposto para com os atenienses e já muitas vezes lhes havia sido útil no passado e ainda seria no futuro.

Heródoto, VI.105.2

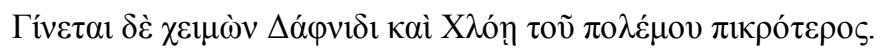

Mas o inverno foi, para Dáfnis e para Cloé, mais amargo do que a

guerra.

Longo, III.3.1 ${ }^{1}$

Desde que foi impresso pela primeira vez, em 1489, Dáfnis e Cloé, de Longo, estabeleceu-se como uma espécie de best-seller do romance antigo, sendo conhecidas cerca de quinhentas edições, traduções e adaptações do texto. ${ }^{2}$ Além de ter sido peça central no desenvolvimento do romance pastoral nos séculos XVI e XVII, a partir da primeira tradução vernacular da obra, feita por Jacques Amyot (1559), ele é hoje conhecido também como tema para um balé de Ravel e para uma série de gravuras de Marc Chagall, recentemente expostas no Museu de Arte de São Paulo. ${ }^{3}$ Sendo a

\footnotetext{
${ }^{1}$ A edição de Longo utilizada nesta tese é a de Reeve para a Teubner (1994).

${ }^{2}$ A história das edições da obra é comentada por Barber (1989) em livro que reúne uma série de palestras apresentadas por ocasião de uma exposição que comemorava, na British Library, os 500 anos da primeira edição de Longo. Há uma edição brasileira do romance, com tradução de Denise Bottman (1990).

${ }^{3}$ Em 2010, na exposição O Mundo Mágico de Marc Chagall. Sobre as gravuras, cf. Cueva (2000-2001).
} 
narrativa introduzida com uma longa écfrasis de um quadro notável que o narrador observa em Lesbos, ${ }^{4}$ ao qual ele sente o desejo de responder por meio escrita, não por acaso ela veio a inspirar, na trajetória inversa, diversos artistas. As aventuras de Dáfnis e de Cloé foram objeto de interesse de vários pintores de salon franceses no século XIX e Barber (1989, p.68) sugere que o sucesso editorial do texto a partir desse momento possa estar relacionado também à sua emergência como favorito do mercado de livros de luxo, recheados de ilustrações. E mesmo no que diz respeito à fortuna crítica, Longo é claramente privilegiado pelos especialistas, algo que os dois comentários textuais recém-editados comprovam. ${ }^{5}$

Vivendo no campo, sob a proteção das Ninfas e de Pã, Dáfnis e Cloé vão, com o avançar do ciclo das estações, descobrindo progressivamente diversos aspectos do amor. Esse tema aparentemente simples permitiu interpretações diversas: ora entendido como escapista e despretensioso, leitura de entretenimento dos homens cultos (pepaideuménoi) contemporâneos de Longo, ora visto como uma espécie de pornografia $^{6}$ ou como uma leitura mais apropriada às mulheres, ${ }^{7}$ ora ainda como um texto simbólico e profundamente religioso, ${ }^{8}$ o romance mais recentemente se tornou objeto de análises provocantes dos gender studies. ${ }^{9} \mathrm{O}$ cenário pastoril, a educação sexual do par central e a ação divina na trama são os elementos que mais parecem instigar os estudiosos e são também aqueles que dão ao texto de Longo um caráter peculiar. Esse é o autor do nosso corpus que com mais liberdade lida com as convenções do romance antigo, a começar pelo fato de que ele não representa o amor à primeira vista. Depois de um despertar erótico assimétrico (primeiro em Cloé, depois

\footnotetext{
${ }^{4}$ A ambientação rural do quadro observado por Longo é algo que auxilia a datação do autor no século II d.C. (Vieillefond 1987 apud Cueva 2004, p.44), um momento em que ela se tornou comum. Perry (1967, p.350, n.17) identifica uma família de Mitilene que teria entre seus membros Pompeius Longus, nomeado cônsul em 49 d.C., e sugere que possa ser a do autor.

${ }^{5}$ Morgan (2004) e Pattoni (2005). Uma edição da coleção Greek and Latin Classics da Cambridge está sendo preparada por Ewen Bowie.

6 "Rohde is offended by the narrative dynamics of the text, and he blames the author for a kind of fundamental bad faith (and aesthetic bad taste) that deludes the reader into the pleasures of savoring an idyllic innocence that was in reality only masking a libertine prurience” (Zeitlin, 1990, p.429).

${ }^{7}$ O romance na tradução inglesa de 1657 de George Thornley recebeu o subtítulo de " $a$ most sweet romance for young ladies".

${ }^{8}$ Por exemplo, as leituras de Chalk e Turner (ambas de 1960), discutidas brevemente na sequência.

${ }^{9}$ Os estudos mais interessantes são de Winkler (1990) e Goldhill (1995).
} 
em Dáfnis), a relação entre os personagens desenvolve-se de um instinto meramente sexual à observação das convenções sociais do matrimônio ao final da narrativa. Além disso, o autor opta por não separar os dois amantes e por não os fazer viajar pelo Mediterrâneo, sendo a viagem substituída por um processo internalizado de amadurecimento dos protagonistas do fim da infância à idade adulta.

A ambientação bucólica e as alusões claras à poesia de Teócrito, que começam já na escolha do nome de Dáfnis, ${ }^{10}$ em conjunto com o tratamento particular que Longo reserva a diversas das convenções do romance antigo levaram ao questionamento da classificação genérica do texto. Effe (1999, p.192), como outros, entende a narrativa como um experimento que sintetiza os gêneros do romance de amor e da poesia bucólica, mas observa que ainda que o autor insira motivos romanescos, como os piratas, o rapto e o naufrágio, eles não passam de expressão de uma ideia temática central, a de que o mundo pastoril goza da proteção de poderes divinos, concluindo que "Longo representa a si mesmo como um Theocritus alter e deseja ser entendido primeiramente como um escritor bucólico" (idem, p.193). Cresci (1999, p.239), em sua análise fundamental do uso reelaborado de tópoi bucólicos na narrativa de Dáfnis $e$ Cloé, observa também que mesmo nas seções que pertencem mais especificamente ao gênero romanesco é possível perceber certa estranheza na invenção dos episódios e na relação entre os distúrbios provocados pelos piratas e pelos metimnenses e o quadro pacífico da vida pastoril.

Hunter (1983, p.64ss), por sua vez, acha que Longo não expressa intenção de associar sua narrativa a nenhum gênero em particular dentre os vários que lhe servem de intertexto, mas argumenta que sua estrutura episódica o distingue do romance grego ideal, pois ainda que a história caminhe para a esperada união dos dois personagens principais, os incidentes e cenas - que configuram reelaborações de tradições poéticas variadas - são praticamente completos neles mesmos. Reardon, porém (1994), ao enfrentar a questão, também despreza, como Hunter, a possibilidade de haver um gênero misto (o "romance bucólico"), mas centra sua análise não na estrutura da

\footnotetext{
${ }^{10}$ O nome ocorre em sete poemas de Teócrito $(1,5,6,7,8,9,27)$ e em cinco das Éclogas de Virgílio (2, $5,7,8,9)$. Alusões frequentes à poesia de Filetas de Cós também são prováveis, ainda que dificilmente identificáveis. Morgan (2004) afirma sua crença de que todas as semelhanças entre Longo e a poesia bucólica latina que não possam ser traçadas a Teócrito devem ter origem comum na poesia de Filetas. Hunter (1983) considera a possibilidade de Longo ter tido acesso à poesia bucólica latina por meio de uma tradução para o grego ou no original.
} 
narrativa, mas na função dos gêneros literários. Para Reardon, o tom bucólico do romance funciona como metáfora: "metáfora idealizante, da inocência, da virtude, da utopia ou do escapismo; ou ele pode servir como código" (idem, p.142). O fato de que há movimento da inocência para a experiência - i.e., a ação, drama - em Dáfnis e Cloé, um elemento central do romance, mas não do pastoral, permite dispô-lo com mais propriedade naquele gênero. "O pastoral não é propício ao drama, pois o drama perturbaria seu mundo ideal, modificando-o".

Ainda que a análise de Reardon me pareça a mais adequada, a classificação genérica da obra de Longo importa menos para a nossa leitura do que a certeza de que os elementos convencionais de violência do romance grego são inseridos não de forma casual, mas, ao contrário, são reconhecidos pelos críticos como reelaborações da tópica do gênero, por sua vez dependentes de um projeto narrativo fortemente influenciado pela poesia bucólica helenística. Nesse sentido, é possível perceber que Longo diversas vezes joga com as expectativas dos leitores, dando a episódios comuns do romance desfechos muito diferentes daqueles encontrados nos demais romancistas, como veremos com relação à presença dos piratas e ao episódio bélico entre Metimna e Mitilene.

\section{III.1 Resumo do Enredo}

A história de Dáfnis e de Cloé tem início em uma propriedade rural próxima de Mitilene, onde um bebê abandonado com ricos objetos de reconhecimento é amamentado por uma cabra. O pastor que o encontra, Lâmon, e sua esposa Mirtale decidem adotá-lo e dar-lhe o nome de Dáfnis. Dois anos depois, outra criança é encontrada quando estava sob os cuidados de um animal, dessa vez uma ovelha; o pastor Drias e sua mulher Nape são os responsáveis pela adoção da menina, a quem dão o nome de Cloé, e que também trazia consigo objetos de reconhecimento caros. Quando as crianças chegam à adolescência, seus pais têm um mesmo sonho com o deus Eros (que não reconhecem) e o interpretam como sinal de que os dois deveriam se tornar pastores.

Em um dia de primavera, Dáfnis cai em um fosso cavado para pegar lobos. Cloé ajuda-o a sair de lá se despindo da faixa que cobria o seu peito, com a qual Dórcon, um 
boiadeiro, consegue puxá-lo. Os dois vão em seguida à caverna das Ninfas, onde Dáfnis se banha. Cloé é tocada pela visão do seu corpo nu e começa a sentir uma angústia que ela não entende, mas que o leitor pode reconhecer como sintoma de uma paixão nascente. Na sequência, ela passa a ser cortejada por Dórcon, que já era experiente nos assuntos de amor, mas Cloé é incapaz de perceber suas intenções. A disputa de Dórcon e de Dáfnis em uma competição de beleza é a situação que permite o despertar do desejo também neste último: Cloé é a juíza que lhe dá um beijo como prêmio e é esse beijo que provoca sentimentos sobre os quais ele igualmente não tem qualquer compreensão. ${ }^{11}$

Como sua corte não surte nenhum efeito, Dórcon decide tomar Cloé à força e veste-se com uma pele de lobo para atacá-la. Ele acaba, porém, sendo mordido por cães que o tomam como um lobo de verdade e é salvo por Dáfnis e por Cloé, que presumem que Dórcon participava de algum tipo de jogo pastoril, uma vez que eram inexperientes

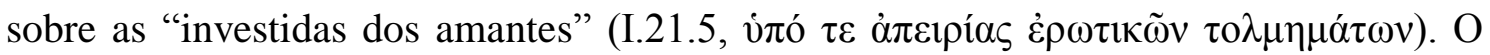
boiadeiro entrará em cena ainda uma última vez. No outono, piratas invadem o campo e Dáfnis é raptado para ser vendido como escravo, mas eles mal conseguem se afastar da costa, pois são impedidos por Cloé. Dórcon, à beira da morte após ter sido agredido pelos piratas, entrega-lhe sua flauta e, com ela, a pastora toca uma melodia reconhecida pelas vacas. Seu movimento em direção ao som provoca o naufrágio do barco; todos os piratas, vestidos com armaduras pesadas, afogam-se, mas Dáfnis consegue retornar à praia com ajuda dos animais.

O início do livro II descreve o fim do período de colheita, quando Dáfnis e Cloé encontram um velho chamado Filetas, cujo nome é uma clara homenagem ao poeta helenístico Filetas de Cós. Ele relata aos dois a epifania de Eros em seu jardim, apresentando o deus aos dois jovens e, nesse momento, eles conhecem, afinal, o nome daquilo que sentem. Deleitados com o que ouviam (como se o relato fosse " $\mu$ ṽ $\theta$ ov ov̉

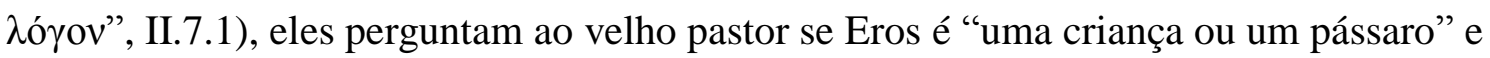

\footnotetext{
${ }^{11}$ I.18.1-2: "O que o beijo de Cloé está provocando em mim? Seus lábios são mais macios do que rosas e sua boca mais doce do que favos de mel, mas seu beijo é mais ardido do que o ferrão da abelha [...] Ó, que vitória infeliz; ai, que doença nova, da qual não sei sequer o nome. Acaso Cloé provou dos venenos

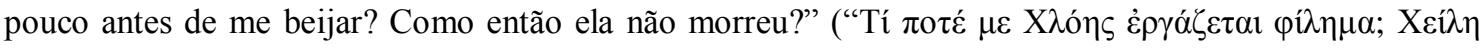

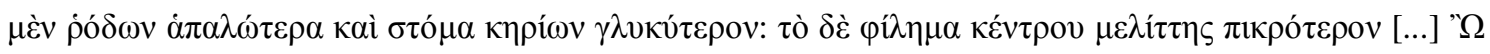

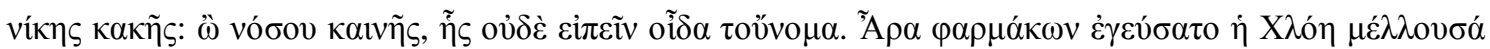

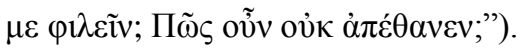


o que ele é capaz de fazer. Na sua resposta, Filetas lhes diz que não há remédio para o amor (II.7.7), "nem algo que se deva beber ou comer ou ser entoado em cantos, a não ser um beijo, um abraço, e deitar juntos com os corpos nus". ${ }^{12}$ O narrador afirma que os dois poderiam ter chegado a descobrir o ato sexual pouco depois, não fosse a chegada de alguns jovens de Metimna ao campo para caçar. Como perdem o seu barco e culpam Dáfnis pelo acontecido, eles são expulsos a pauladas pelos camponeses após se recusarem a aceitar o veredito de inocência do pastor e, assim, acabam provocando o início de uma guerra entre sua cidade e Mitilene. Cloé é levada no butim, mas o deus Pã interfere e faz com que ela retorne a salvo para o campo junto com seus animais.

Logo no início do livro III, no entanto, o episódio bélico é concluído: os cidadãos de Metimna descobrem as mentiras dos jovens que provocaram os atritos e decidem apresentar um pedido de paz a Mitilene, já então organizada para revidar o ataque e que julga que aceitá-lo seria mais vantajoso do que a guerra. Na sequência tem início o inverno, que impede que os jovens amantes se encontrem com a mesma frequência de antes, mas, com a chegada da primavera, Dáfnis sugere a Cloé que eles se deitem nus, seguindo o conselho de Filetas. Cloé, por sua vez, observa que os animais mantêm relações de pé e sem tirar suas "roupas". Então eles permanecem vestidos e Dáfnis a abraça por trás, imitando os bodes. Como nada disso surte efeito, o menino chora por se sentir "mais ignorante do que um bode nos trabalhos do amor" (III.14.5,

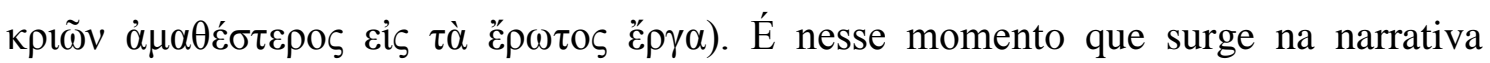
Licénion, uma jovem da cidade e esposa de um velho fazendeiro das bandas, e Dáfnis tem, então, sua primeira experiência sexual, que ele anseia por repetir com Cloé. Seu desejo só é refreado quando Licénion lhe diz que na primeira vez ela irá sofrer, chorar e sangrar muito.

Com o início do verão, Cloé recebe a atenção de muitos pretendentes. Para ajudar Dáfnis, as Musas aparecem em seus sonhos e contam a ele onde estava uma grande quantia de dinheiro perdida pelos jovens metimnenses. Com esse dinheiro, Dáfnis obtém do pai de Cloé a permissão de se casar com ela, mas Lâmon observa que o casamento deve ser antes aprovado pelo senhor da propriedade, Dionisófanes. No quarto e último livro, durante o outono Dionisófanes decide verificar se a guerra havia causado estragos em sua propriedade, dirigindo-se ao campo com uma comitiva da

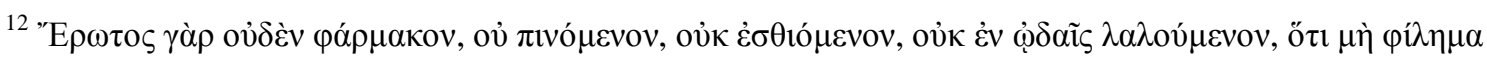

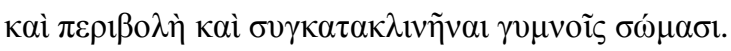


cidade que incluía seu filho Ástilo e o parasita Gnathon. Sendo "por natureza atraído

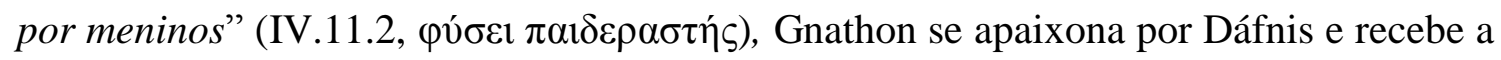
permissão de levá-lo consigo para a cidade. Nesse momento, Lâmon sente necessidade de revelar que Dáfnis foi encontrado ao lado de ricos objetos de reconhecimento e que não deveria estar em posição de se tornar um mero brinquedo do parasita. Dionisófanes reconhece então o jovem pastor como o filho que ele próprio havia abandonado. A alegria só não é maior porque Lâmpis, um ex-pretendente de Cloé, decide nesse momento raptá-la. Gnathon vê aí a chance de se redimir com Dáfnis e a salva. Então é a vez de Drias revelar que Cloé também foi exposta quando bebê e Dáfnis e Cloé acompanham Dionisófanes até Mitilene onde descobrem seu pai, Megácles, também um aristocrata da cidade.

Todos retornam, na sequência, para o campo, onde Dáfnis e Cloé celebram seu casamento e onde decidem permanecer. O narrador conta que o casal teve dois filhos, um menino e uma menina, que foram como eles amamentados por uma cabra e uma ovelha. A narrativa encerra-se com a descrição da noite de núpcias do par, quando Cloé finalmente descobre pela primeira vez que "o que eles fizeram no campo não tinha sido

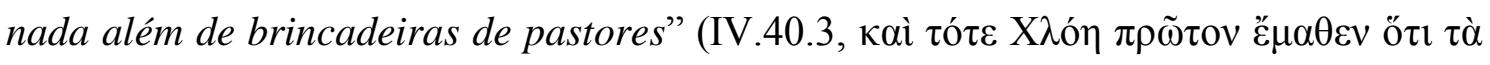

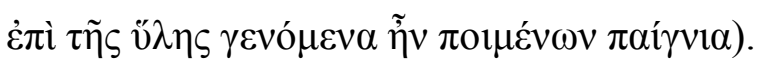

\section{III.2 O proêmio de Dáfnis e Cloé}

O cenário bucólico da narrativa é, em parte, justificado pelo quadro que, no proêmio da obra, o narrador afirma ter visto no bosque das Ninfas em Lesbos, aonde ele

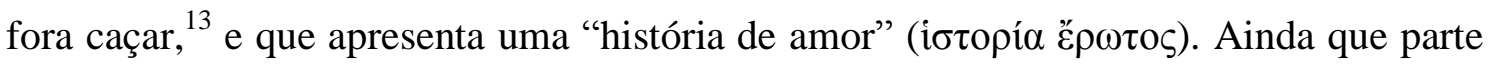
da tradição crítica de Longo tenha sido dedicada a examinar ocorrências que indiquem uma representação realista de Lesbos, ${ }^{14}$ formando, aliás, opinião positiva sobre a questão, o proêmio também já está inserido no projeto ficcional do autor, como se

\footnotetext{
${ }^{13}$ Sobre o narrador como caçador, cf. Paschalis (2005).

${ }^{14}$ Cf. Mason (1979 e 1995) e Bowie (1985).
} 
discutirá na sequência, de modo que a menção à ilha forja uma relação entre o texto e a tradição literária que estabeleceu Safo como a grande poetisa do amor. ${ }^{15}$

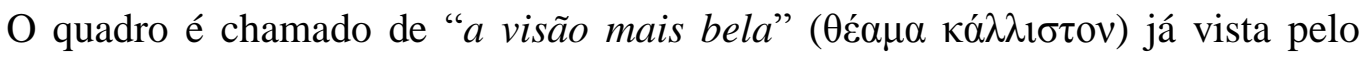
narrador. Belo também é o bosque em que ele se encontra, mas "mais agradável é a pintura" ( $\dot{\eta} \gamma \rho \alpha \varphi \eta ̀ ~ \tau \varepsilon \rho \pi v o ́ \tau \varepsilon \rho \alpha)$. Essa comparação logo no início do proêmio introduz ao leitor uma relação que se desenvolverá plenamente ao longo da narrativa, entre natureza ( $\varphi v ́ \sigma ı \zeta)$ e arte ( $\tau \varepsilon ́ \chi \vee \eta)$. A afirmação da superioridade desta sobre aquela deve também ser considerada programática no que diz respeito às prerrogativas do discurso literário de Longo e anuncia as relações miméticas complexas que o autor explorará na sequência. "O desejo daquele que observa [o quadro] é também um desejo de mímesis", observa Zeitlin (1994, p.149), considerando que Longo chama a atenção, no proêmio, para o uso do termo tanto na relação entre uma obra de arte e a realidade quanto na emulação de modelos considerados dignos de imitação. Além disso, se os dois jovens pastores do romance aprendem alguns aspectos do amor (ainda que não todos) por meio da imitação, em um processo entendido, desde Aristóteles, como uma tendência natural do homem (Poética, 1448b4), é possível perceber que Longo introduz também o

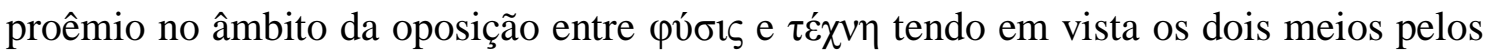
quais ocorre o amadurecimento sexual dos personagens ao longo da narrativa. Diversos dos elementos do quadro são então enumerados:

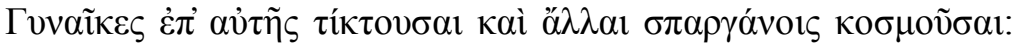

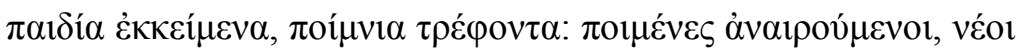

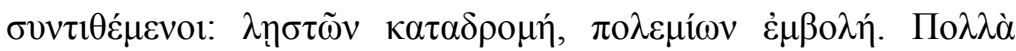

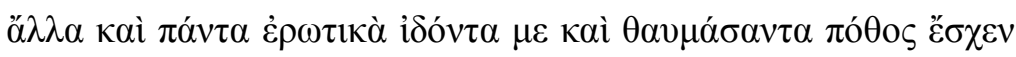

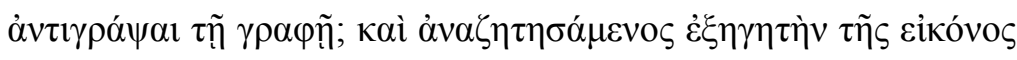

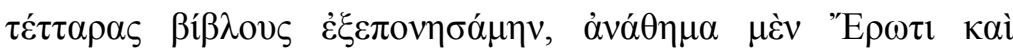

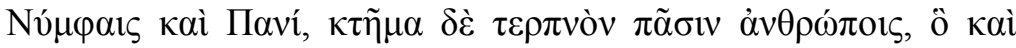

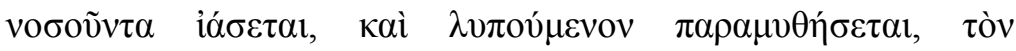

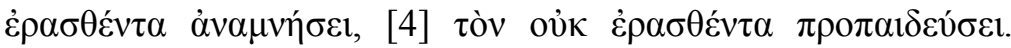

\footnotetext{
15 A localização do quadro no bosque também foi interpretada como algo significativo para o projeto de Longo. Hunter (2008) vê no proêmio uma alusão ao Fedro de Platão que anuncia a relação entre os dois textos ao longo da narrativa: "Just as the opening of Plato's dialogue brings Socrates into a new site for the practice of philosophy, so the opening of the novel brings us and the narrator into the arena of the Phaedrus. In this way the work both patterns itself upon and marks its progression from Plato's work" (p.786). Para a posição privilegiada do diálogo Fedro na Segunda Sofística, cf. Anderson (1993, p.75-78).
} 


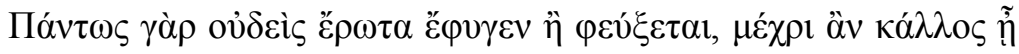

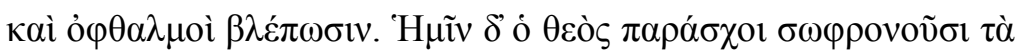
$\tau \tilde{\omega} v \stackrel{\alpha}{\lambda} \lambda \omega v \gamma \rho \alpha \dot{\varphi} \varphi \varepsilon 1$.

Mulheres dando à luz, outras envolvendo bebês em mantas, crianças expostas, animais alimentado-as, pastores que as recolhiam, jovens trocando juras, um assalto de piratas e um ataque de inimigos. Também várias outras coisas, todas relacionadas ao amor, ao vê-las e admirá-las, tomou-me um desejo de escrever em resposta à pintura. Tendo procurado um intérprete da imagem, quatro livros lavrei, oferenda a Eros e às Ninfas, de um lado e, de outro, patrimônio agradável para todos os homens, que tanto o doente irá curar quanto o que sofre consolará, e o que já amou fará recordar e o que nunca amou irá preparar. Pois ninguém certamente fugiu ou fugirá do amor, enquanto beleza houver e olhos para observá-la. E que a nós o deus conceda sermos castos ao escrever sobre a vida dos outros.

Esse proêmio programático é uma ocorrência ímpar entre os romances de amor e resulta em uma quebra entre a voz inicial em primeira pessoa e o narrador onisciente que relata a história de Dáfnis e de Cloé. Dentre os demais romances, o que mais se aproxima dele é a apresentação da ocasião da narrativa de Aquiles Tácio, em que o narrador inicial, ao observar um quadro que retrata o rapto de Europa, é interpelado por Clitofonte, em quem a imagem faz despertar lembranças e de quem ouvirá o relato de suas aventuras. O fato de a história de Dáfnis e Cloé passar por um pintor e por um intérprete dessa pintura antes de chegar ao narrador e a própria convenção da écfrasis ensejando uma narrativa em Aquiles Tácio são elementos que Reardon (1991, p.48) entendeu como uma convenção acadêmica que permite aos autores tanto se distanciar quanto praticar, no seio da Segunda Sofística, um tipo de literatura cujo status não seria dos mais elevados. ${ }^{16}$ Porém, ao mesmo tempo em que o quadro pode deixar explícita a ficcionalidade da história que será narrada (ao tomar como referência não a realidade, mas uma obra de arte), ele também pode fazer com que o leitor mais atento entenda que

\footnotetext{
${ }^{16}$ Whitmarsh (1998, p.110) observa também que o fato de a semelhança de Caricleia com uma pintura ser a raison d'être da narrativa de Heliodoro pode estar relacionada de forma irônica à convenção explorada por Longo e Aquiles Tácio.
} 
o intérprete ${ }^{17}$ da imagem auxilia o autor a relatar fatos essencialmente verídicos. Wouters (apud Morgan, 2004, p.147) foi o primeiro a sugerir que a pintura descrita pelo narrador deve ser identificada com aquelas que Dáfnis e Cloé teriam consagrado às Ninfas após seu casamento, desse modo introduzindo por meio da experiência do narrador uma forma de autenticação ${ }^{18}$ da história que conta: "Eles embelezaram a caverna, dedicaram imagens, ergueram um templo para Eros Pastor e deram a Pã um templo para viver no lugar do pinheiro, chamando-o de Pã Soldado" (IV.39.2). ${ }^{19}$

Interessa observar, porém, que a pintura não provoca no narrador de Longo um desejo de relatar suas próprias experiências amorosas, como no caso de Clitofonte, mas se trata de um impulso de emulação essencialmente estético. No trecho acima citado, o autor joga com ambiguidades criadas a partir do uso do verbo $\gamma \rho \alpha ́ \varphi \omega$ (na expressão

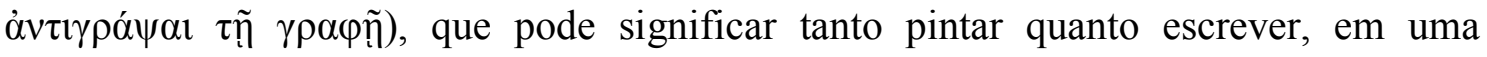
demonstração de sofisticação que já havia se feito presente também no uso do termo

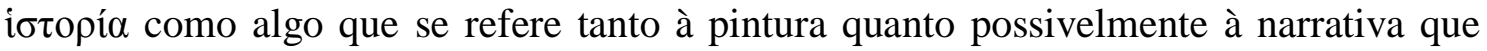
lhe deu origem. A reação considerada apropriada a um pepaideuménos quando de uma experiência visual excepcional como a pintura mencionada no proêmio de Dáfnis e Cloé é a produção de um discurso. ${ }^{20}$ Além disso, a vontade de "contraescrever" a imagem, i.e., de produzir um antígraphos, não sugere uma mera cópia, mas a intenção de superação artística. A partir disso, Longo explora a écfrasis desse quadro de duas formas usuais: pretende-se possibilitar a visualização das imagens para os leitores por

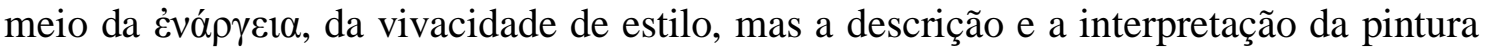
também servem de ocasião para o desenvolvimento de um tema ético. $\mathrm{O}$ fato de $\mathrm{o}$ narrador tomar como ponto de partida a leitura de um quadro, além disso, justifica uma característica estrutural sem igual entre os romances de amor conhecidos, o mundo bucólico fechado do qual os personagens pouco se afastam.

Partindo da classificação de Lessing de artes espaciais (pintura, escultura e arquitetura) e temporais (como música e literatura), Kestner observa (1973, p.168) com relação ao proêmio que "o atributo essencial da arte espacial é a simultaneidade; da

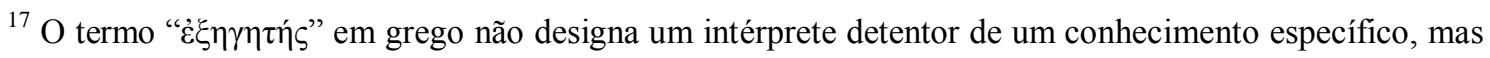
tinha uso variado que incluía até guias de viagem. Cf. Luciano, Calumn.5 e Winkler (1985, p.235ss).

${ }^{18}$ Estratégias de autenticação são um tópos das narrativas populares. Cf. Hansen (1997).

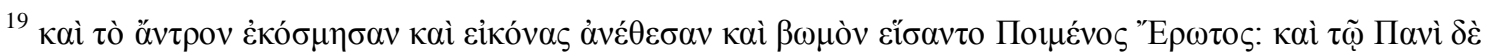

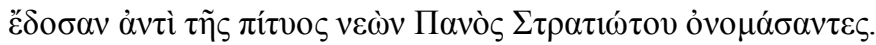

${ }^{20}$ Cf. Luciano, Sobre a Sala, 1.
} 
arte temporal, é a sucessão. [...] $O$ olho vaga pela pintura inicial (indicada pelo arranjo aleatório do seu conteúdo), mas não se pode ler o romance a não ser em sucessão". Dessa forma, cabe ao narrador, a partir do que ele vê no quadro e do que lhe diz o intérprete, criar relações entre os vários elementos por ele enumerados, sobre os quais se estabeleceu a opinião comum de que eles representam os fatos principais do enredo de Dáfnis e Cloé: i) o nascimento dos protagonistas; ii) o abandono pelos pais; iii) os animais que cuidaram deles; iv) a adoção por pastores; v) o tempo que eles passam juntos; vi) a invasão dos piratas; e vii) o ataque dos metimnenses. Trzaskoma (2005, p.81), porém, recentemente argumentou que essas são apenas as primeiras cenas do romance (de fato, seis dos sete elementos mencionados são desenvolvidos no livro I)

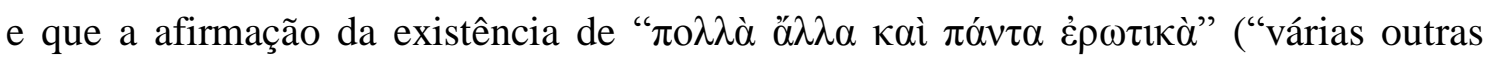
coisas, todas relacionadas ao amor") provoca uma expectativa no leitor acerca do que irá acontecer após a invasão dos inimigos, que Longo resolveria de forma inesperada ao não desenvolver o tema da guerra como os demais romancistas. Mais importante do que isso, porém, é o fato de que a rápida menção aos objetos representados na pintura serve para esclarecer ao leitor a que tipo de narrativa a écfrasis dessa obra de arte levará. Assim, anuncia-se que a descrição não se desenvolverá como uma peça retórica típica da prática sofística da época, mas se sugere que o leitor está diante de uma narrativa de amor, do qual o rapto por piratas e a guerra são dois dos temas mais típicos, gerando uma expectativa, na verdade, com relação à possibilidade dos protagonistas serem raptados do mundo pastoril em que vivem, como se discutirá na sequência.

Há duas outras observações a se fazer com relação ao trecho citado do proêmio. Elas dizem respeito à alusão a Tucídides, por um lado, quando o narrador diz que os quatro livros em que se divide a obra são um "patrimônio agradável para todos os

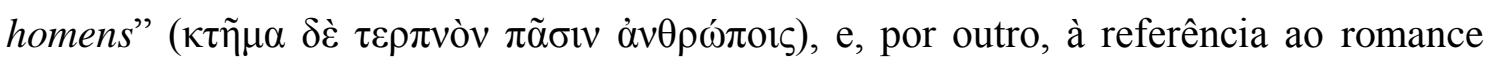
como “oferenda a Eros, as Ninfas e a Pã". Como observa Morgan (2004, p. 147), “a leitura e a visão [do quadro] são ambas simultaneamente uma experiência religiosa e estética”. Muito já se discutiu a alusão a Tucídides nessa declaração, que faz ecoar a célebre passagem abaixo, na qual o historiador reflete sobre o método que emprega na História da Guerra do Peloponeso (I.22.4): ${ }^{21}$

\footnotetext{
${ }^{21}$ Luginbill (2002) oferece a leitura mais cuidadosa do proêmio no que diz respeito aos possíveis paralelos com a obra de Tucídides.
} 


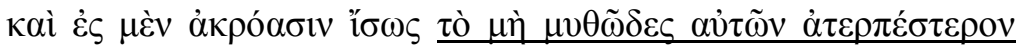

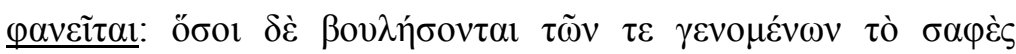

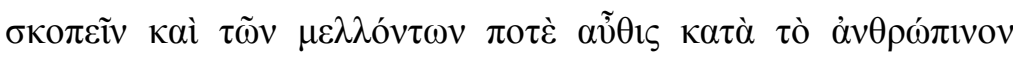

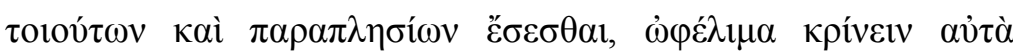

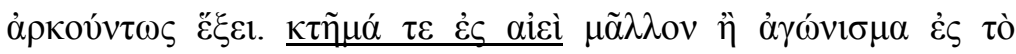

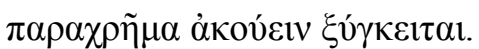

E para o auditório o caráter não fabuloso dos fatos narrados parecerá talvez menos atraente; mas se todos quantos querem examinar o que há de claro nos acontecimentos passados e nos que um dia, dado o seu caráter humano, virão a ser semelhantes ou análogos, virem sua utilidade, será o bastante. Constituem mais uma aquisição para sempre que uma peça para um auditório do momento. ${ }^{22}$

Está claro que Longo expõe com aprovação aquilo que Tucídides reprova, i.e., o caráter prazeroso de sua narrativa, subvertendo o princípio tucididiano, pois a utilidade, no seu caso, também advém do prazer que o texto pode oferecer ao leitor que ama e que, por isso, precisa de consolo. Ambos os autores parecem concordar, porém, no fato de que é o aspecto mítico de uma narrativa aquilo que a torna mais agradável ao público e a avaliação positiva do romancista o associa antes a Heródoto do que ao historiador ateniense. $^{23}$ Mas a atenção dada ao caráter "agradável" do texto não diz respeito somente à ficcionalidade do discurso romanesco por oposição à historiografia tucididiana. Além disso, ao utilizar a expressão $\kappa \tau \tilde{\eta} \mu \alpha \tau \varepsilon \rho \pi v o ́ v$, Longo chama a atenção para o intuito de emular Teócrito e a poesia que ele chama de $\dot{\eta} \delta$ ́́ $\varsigma$, prazerosa. ${ }^{24} \mathrm{Com}$ efeito, outros elementos estruturais de Dáfnis e Cloé emulam a poética alexandrina, como a magnitude reduzida dos eventos em comparação com os demais romances e a

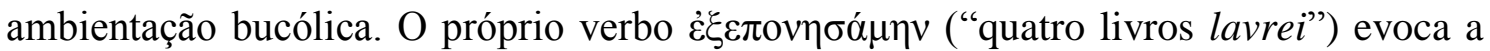
ideia do trabalho cuidadoso e extenuante como princípio poético, uma imagem cara aos

\footnotetext{
22 Tradução de A. L. de Almeida Prado (1999).

23 Cf. Hunter (1983, p.49s e 97s), que observa que as Histórias eram consideradas pelos retores contemporâneos a Longo um modelo do estilo $\gamma \lambda \nu \kappa v ́$, adotado pelo romancista.

${ }^{24}$ Cf. Hunter (idem, p.48).
} 
alexandrinos. ${ }^{25}$ Por outro lado, acredita-se que Longo estaria aí também marcando o estilo do romance como $\gamma \lambda$ $\nu$ $v \eta \eta$, , doce, um tipo de estilo do qual temos uma descrição

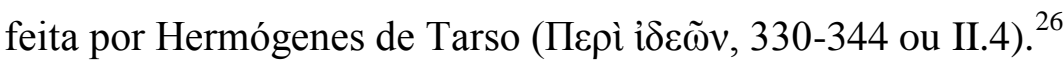

Se, por um lado, Tucídides entende o mítico como uma intrusão inapropriada em um discurso que se pretende patrimônio eterno da humanidade por registrar um "quadro acurado do comportamento humano (individual e coletivo) no processo histórico" (Luginbill, 2002, p.242), que permitiria aos leitores do porvir analisar a situação vivida por eles mesmos com mais propriedade, por outro lado, Longo, ao fazer ecoar deliberadamente a passagem mais célebre da exposição metodológica do historiador, parece alegar que há algo sobre o comportamento humano em seu romance que ele igualmente considera universal e que lhe garante, portanto, um caráter pedagógico. Nem a eternidade da sua obra deixa de ser mencionada, ${ }^{27}$ pois o $\dot{\varepsilon} \zeta$ aikì tucididiano é substituído pela declaração de que a leitura será de utilidade para os leitores que amam, amaram ou amarão, pois "certamente ninguém fugiu ou fugirá do amor, enquanto houver beleza e olhos para observá-la".

Mas quão séria é a alegação de Longo sobre a utilidade do seu romance? Pareceme que o uso da expressão $\kappa \tau \tilde{\eta} \mu \alpha \tau \varepsilon \rho \pi v o ́ v$ é uma manifestação do humor sofisticado de Longo, que se apropria e desloca um tópos de proêmios historiográficos, a comum declaração da importância e utilidade da narrativa, ao anunciar que no seu romance eles se realizam não na esfera pública das grandes guerras, mas na da experiência erótica

\footnotetext{
${ }^{25}$ Morgan (2004, p.149). Luginbill (2002, p.240), por sua vez, vê referência ao advérbio غ̇ंı por Tucídides (I.22.3) na exposição de sua metodologia.

${ }^{26}$ A discussão mais completa do uso do estilo doce por Longo é feita por Hunter (op.cit., p.92ss). O estilo é caracterizado pela simplicidade ( $\alpha \varphi \varepsilon ́ \lambda \varepsilon ı$ ) na dicção e pelo arranjo métrico das palavras. Os discursos doces que oferecem prazer (†்ovท́) ao leitor são particularmente as narrativas míticas (como o mito das

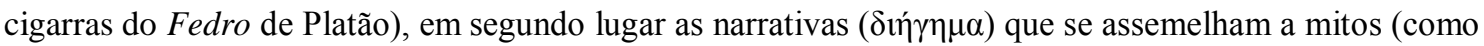
a guerra de Troia) e, em terceiro, aquelas que misturam mito e verdade, com menor presença do primeiro elemento, como as Histórias de Heródoto. Como se pode observar, importa o aspecto fabuloso na gradação proposta pelo retor. Em seguida, Hermógenes toca em diversos aspectos do estilo doce identificáveis no texto de Longo, ao afirmar que tudo aquilo que agrada aos sentidos quando descrito também provoca prazer, apresentando como exemplo a descrição de "belas paisagens, vegetação rica, rios" (331). Para Hermógenes, "em geral todos os pensamentos que dizem respeito ao amor são doces" (333). O retor menciona, além disso, como característica igualmente importante do estilo doce a presença de citações ou alusões entrelaçadas à narrativa, que com ela devem formar uma unidade (336-338).

${ }^{27}$ Cf. Luginbill (2002, p.242) e Trzaskoma (2005, p.89).
} 
individual do leitor. Assim, Longo se mantém na tradição (talvez iniciada pelo próprio Cáriton) de apresentar um proêmio que alude à historiografia, sem deixar de enfatizar as diferenças entre os dois gêneros.

Chalk (1960) e Turner (1960), porém, entenderam o proêmio como uma declaração do autor de que seu texto possui um sentido literal e outro simbólico: “Longo alerta-nos a entender sua obra de forma séria e a não nos enganarmos pela leveza e pelo humor do seu estilo" (Turner, idem, p.118). O Amor seria o tema central da obra, não como mecanismo literário que põe em movimento as ações dos personagens, mas como força criativa da natureza como um todo. A leitura de Chalk, por sua vez, coloca em equilíbrio os aspectos poéticos e simbólicos da narrativa, mas ressalta o caráter iniciatório da obra no culto a Dioniso, com quem Eros seria identificado nas práticas religiosas órficas. ${ }^{28}$ Essa visão foi influente e, mesmo em uma leitura como a de Effe (1999, p.194), que privilegia as relações intertextuais do romance, o elemento bucólico é visto, de um lado, como expressão de um desejo contemporâneo urbano pela simplicidade rural, nunca, porém, levado a sério pelo narrador e, por outro lado, como algo que carrega em si uma doutrina religiosa.

Na leitura de Chalk do texto como representação do culto de Dioniso, entende-se que ele apresenta a instrução de Dáfnis e de Cloé como um lógos sagrado reconhecido pelos iniciados. Essa restrição, por si só, apresenta um problema quando se considera o fato de que Longo anuncia no proêmio que sua obra será um "patrimônio agradável" de utilidade universal. Anderson (1982, p.46) observa também que ainda que a figura do exegeta possa sugerir um mistagogo, Longo não deixa de marcar que a "veneração no templo de Pã não passava de uma desculpa para observar o quadro". De fato, o narrador declara que estava no bosque caçando, como se o acaso o tivesse levado a encontrar a pintura e diz ainda que sua fama atraía muitos estrangeiros, dos quais parte

\footnotetext{
${ }^{28}$ Uma análise extrema nesse sentido, independente da de Chalk, mas a ela semelhante, foi desenvolvida por Merkelbach. Os mistérios dionisíacos foram importantes no período imperial e são atestados em Lesbos, onde a história se passa. Na iniciação, jovens citadinos voltariam ao campo onde representariam um retorno à Era de Ouro. Diversos elementos dionisíacos estão, de fato, presentes no romance e os personagens de Licénion e Filetas foram entendidos como mistagogos, ao passo que Dionisófanes representaria a epifania do deus. Para um resumo sucinto das muito criticadas hipóteses, cf. Morgan (1997, p.2256-2257). Não se teve acesso direto ao livro de Merkelbach (1962).
} 
se dirigia até lá para venerar as Ninfas, mas outra parte com intenção de admirar o famoso quadro. ${ }^{29}$

A leitura alegórica de Dáfnis e Cloé foi criticada por Hunter (1983, p.46s), que observa que Longo pouco se vale de um discurso alegórico e que ele chama a atenção para o aspecto "místico" no romance de forma clara quando deseja fazê-lo. Longo, de fato, transmite claramente a impressão de que a história possui uma "teologia" na qual Eros e Dioniso controlam a natureza e as ações do romance de uma forma geral, desde a mudança das estações até o crescimento de Dáfnis e de Cloé da infância à idade adulta. ${ }^{30}$ Para o crítico, porém, o narrador parece, na verdade, querer dar a impressão de ter adicionado $\tau \dot{\varepsilon} \chi v \eta$ a um mito local ( $\mu \tilde{0} \theta$ os ou i $\sigma \tau o \rho i ́ \alpha)$ retratado no quadro, que passa a ter um sentido mais profundo a ser descoberto pelo leitor. Hunter (1996) entende, desse modo, que o narrador de Dáfnis e Cloé universaliza a importância de sua história, porque ela nos faz recordar ou nos ensina precisamente a experiência universal de Eros, estando os conceitos de importância universal e de proveito pedagógico fortemente relacionados. É como se o casal central de Dáfnis e Cloé representasse a invenção do amor, e sua história fosse um "paradigma fundador" da experiência erótica, no qual Longo exploraria as semelhanças entre o locus amoenus bucólico tradicional e a abundância natural associada à Era de Ouro.

Por outro lado, parece-me que Reardon (1990) aponta o problema central da leitura de Dáfnis e Cloé como representação dos mistérios, ao analisar a tensão criada entre um cenário bucólico propenso ao idealismo simbólico e as ações dos personagens que devem levar adiante esse projeto alegórico. Nesse sentido, o ethos de Dáfnis e de Cloé pode fazer sentido em sua extrema inocência dentro de uma apresentação do poder cósmico do Amor e da iniciação nos seus diversos aspectos, mas todos os outros personagens são representados de forma "realística", como o pai de Dáfnis, que a despeito de se chamar Dionisófanes ("a aparição de Dioniso"), abandona o filho quando bebê por já ser pai de outras três crianças. Ou o pai adotivo de Cloé, que sabendo que

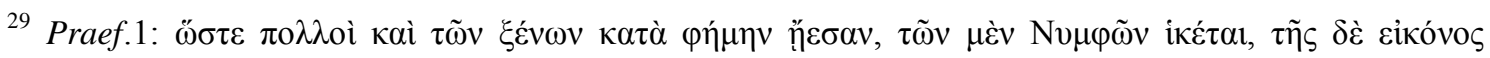
$\theta \varepsilon \alpha \tau \alpha i ́$.

${ }^{30}$ Dáfnis e Cloé apaixonam-se em uma primavera e o sentimento se desenvolve ao longo do verão; na sequência, durante o outono, eles encontram Filetas, quem lhes dá uma importante lição sobre o Amor que eles tentam pôr em prática. O inverno diminui consideravelmente os seus encontros, mas na segunda primavera o desejo entre os dois se torna mais intenso e Dáfnis recebe a lição de Licénion. O casamento, finalmente, ocorre no outono.
} 
ela deve pertencer a uma família rica, a princípio não quer dar a sua mão a um mero camponês, mas muda rapidamente de ideia assim que Dáfnis aparece com um saco de moedas. Ou ainda os pescadores que remam apressados para ir vender seu peixe a um cliente rico da cidade. Há uma constante ironia ao longo da narrativa produzida na tensão entre "realismo" e "idealismo" que não parece apropriada, se consideramos uma leitura séria e religiosa do texto. Nesse sentido, a extrema inocência do par central não tem uma função dentro de uma alegoria, mas é ela própria tratada com comicidade pelo autor. Reardon chama a atenção para como Longo calcula a dosagem de "real" e "ideal" nos diversos episódios e na própria economia da obra, observando que após a sedução de Licénion, o autor passa de um registro idílico para um realístico. Com a conclusão do aprendizado de Dáfnis, a ação ganha contornos de Comédia Nova e o próprio estilo torna-se mais simples: "não mais encontramos as elaboradas estruturas em trícolon que caracterizavam as cenas pastorais anteriores" (idem, p.144).

A inocência de Dáfnis e de Cloé, que iniciam a história sem sequer conhecer a palavra e o deus Eros, está no centro da disputa entre os críticos que advogam uma leitura séria ou despretensiosa e contrasta com a engenhosidade do narrador. A sua apresentação como homem da cidade, um pepaideuménos que fora ao campo caçar, associa-o aos leitores do romance (e também aos jovens metimnenses e à comitiva que chega de Mitilene ao final do livro III) e tal identificação é enfatizada no pedido que encerra um proêmio de evidente sofisticação: “Que o deus nos conceda sermos castos

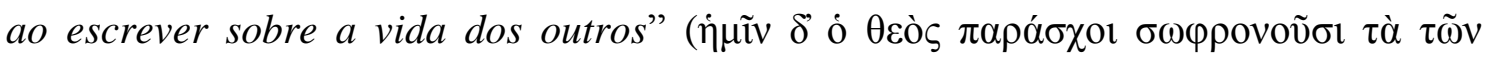
$\left.\alpha ̋ \lambda \lambda \omega v \gamma_{\rho} \alpha \dot{\varphi} \varphi \varepsilon 1\right) .{ }^{31}$ Ao reelaborar elementos de tradições literárias variadas, Longo compôs um texto "quase inteiramente mimético", cujos prazeres são duplos: "o leitor é convidado a ver por meio de duas lentes: a da criança ingênua cujo aprendizado inicial fornece o enredo da história e o do voyeur sofisticado a quem é permitido participar em ambos os campos de percepção" (Zeitlin, 1994, p.154).

O propósito pedagógico do romance, que pretende educar o leitor inexperiente nos assuntos eróticos, sobrepõe-se ao próprio aprendizado de Dáfnis e de Cloé sobre o amor, tratado convencionalmente tanto no proêmio quanto na narrativa como uma doença, cujos remédios são, segundo o velho pastor Filetas, "um beijo, um abraço e deitar juntos com os corpos nus". A lição de Filetas leva os jovens ao comportamento

\footnotetext{
${ }^{31}$ Para uma leitura diferente, cf. Bowie (2007), que analisa a relação intertextual entre as duas últimas frases do proêmio e o gênero trágico.
} 
descrito em II.10, em que eles tentam em vão praticar sexo imitando os animais, agindo contra todas as convenções sociais apropriadas a dois jovens aristocráticos da cidade. Como observa Morgan (2003, p.178), a prece ao final do proêmio indica a necessidade sentida pelo narrador de alertar contra o tipo "errado" de leitura - que levaria à mímesis

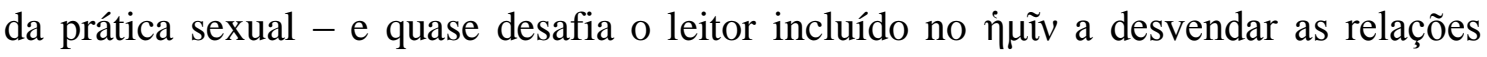
literárias que subjazem no texto.

\section{III.3 O prazer da guerra e da violência}

Que uma leitura de Dáfnis e Cloé como alegoria referente aos mistérios de Dioniso não se sustenta é algo que parece suficientemente argumentado pela crítica recente. Anderson, ainda em 1982, já havia apresentado vários outros pontos na sua análise contrária à leitura religiosa do texto. A presença de Licénion, que mostra então na prática aquilo que Dáfnis não tinha conseguido entender no discurso figurado de Filetas, por exemplo, “coloca mais claramente os deuses no seu lugar" (p.47): embora ela alegue ter sonhado com as Ninfas e diga a Dáfnis que as deusas lhe pediram para instruí-lo nos assuntos amorosos, para os leitores sua atitude aparentemente nada tem a ver com Pã ou com as Ninfas, mas com seu próprio desejo. ${ }^{32}$ Além disso, o nome do pai de Dáfnis, “Dionisófanes”, significa “aparição de Dioniso”, i.e., trata-se do próprio deus supostamente celebrado ao longo do texto e que surge ex machina no fim da história para colocar os jovens de volta à sua devida posição aristocrática. No entanto, o nome pode ser entendido também como ironia (idem, p.46): "esse agente da providência divina acaba se mostrando nada mais do que um pai tipicamente burguês da Comédia Nova".

\footnotetext{
${ }^{32} \mathrm{O}$ narrador introduz da seguinte forma o encontro de Licénion com o par amoroso (III.15.5): “sentindo pena dos dois infelizes e julgando que uma oportunidade dupla se apresentava, de um lado para a

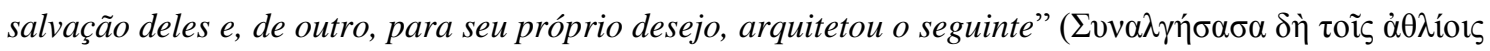

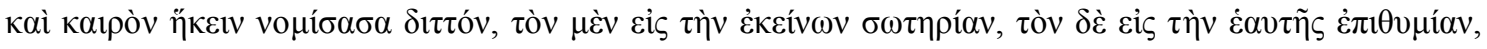

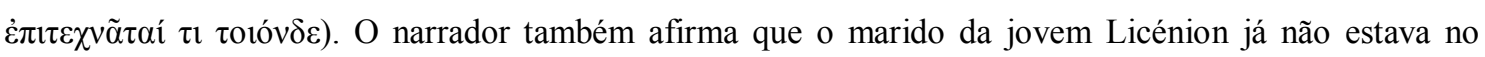

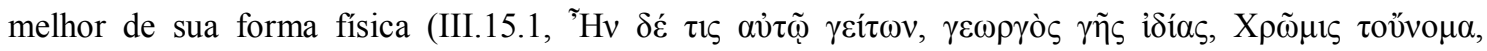

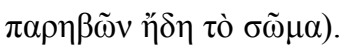


Como se pode notar pelos argumentos de Anderson e de Reardon, a refutação da seriedade simbólica do texto significou muitas vezes também salientar os aspectos cômicos do romance. De fato, o humor de Longo notavelmente explora o idealismo presente na representação do amadurecimento de Dáfnis e de Cloé e do mundo bucólico no qual eles estão inseridos, e isso é verdade também no que diz respeito às convenções do gênero romanesco. Produzir ironia ou humor a partir da paródia, porém, não é necessariamente a única função da tópica relacionada à guerra e à violência na narrativa. Vivendo sob a lei da natureza, diferentemente dos protagonistas de outros romances de amor, nem Dáfnis nem Cloé se esforçam para manter sua virgindade, e os dois a princípio têm uma percepção equivocada daquilo que o leitor percebe como ameaças de agressão sexual, mas seu conhecimento evolui conforme os episódios vão se sucedendo. Do mesmo modo, ainda que centrada no aprendizado erótico de um casal de pastores, violências de outra ordem perpassam Dáfnis e Cloé em diversas ocasiões e, se vemos o rapto por piratas e a guerra serem propositadamente interrompidos, provocando assim menos angústia e sofrimento do que em outros romances, a própria irrupção da violência e a maneira como ela é afastada mostram-se significativos no que dizem respeito ao amadurecimento dos personagens.

É fato que a narrativa de Longo tem nuanças muito particulares. Como observa Goldhill (1995, p.33), “em contraste com os outros romances [...] Dáfnis e Cloé distingue-se pela dissolução das ameaças de violências em uma distância burlesca, cômica e mítica". A violência convencional do romance é reelaborada tendo em vista a intenção de Longo de escrever uma história de amor prazerosa, um ktéma terpnón, e é ainda inserida no enredo por meio de narrativas míticas contadas pelos personagens. Se o narrador de Quéreas e Calírroe afirma, no início do oitavo e último livro do romance,

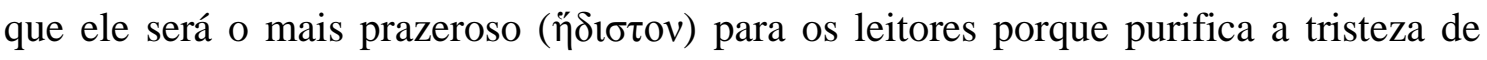
eventos anteriores (e aí se mencionam piratas, escravidão, processos judiciais, lutas, suicídio, guerras e conquistas), Longo parece ter desejado tornar agradáveis e dar final feliz a esses mesmos tipos de eventos ao longo de todo o romance, o que é favorecido pela estrutura episódica da narrativa, uma vez que a maior parte deles é completa em si mesma.

Dórcon veste-se com a pele de um lobo para atacar Cloé, mas é mordido por cães no momento do ataque e o casal sequer consegue compreender a violência de que a garota foi vítima. O boiadeiro é posteriormente reabilitado ao dizer para ela, antes de morrer, como salvar Dáfnis dos piratas - ganhando no fim até um beijo. Gnathon, louco 
de desejo, tenta agarrar Dáfnis à força, mas bêbado, é empurrado e cai no chão, e depois vira herói ao salvar sua noiva. Cloé é raptada por um ex-pretendente inconformado com a rejeição, Lâmpis, mas depois de ser obrigado por Gnathon a devolvê-la, ele aparece no final da história celebrando com os noivos o seu casamento. É graças à ação das vacas que estavam junto de Dáfnis no navio e que atendem ao som da flauta de Cloé que ele escapa dos piratas que o haviam raptado com intenção de vendê-lo. E o narrador aproveita para "instruir" o leitor informando-lhe que as vacas são exímias nadadoras, exceto quando as unhas de seus cascos caem - e há, afinal, diversos lugares chamados

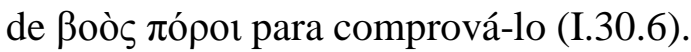

De fato, se as agressões sexuais resolvem-se em desenlaces agradáveis, o mesmo efeito parece ser empregado no ataque dos piratas e na guerra, quando Longo, como bem observou Cueva (2004, p.54ss), transforma em terpnótera (mais agradáveis) eventos históricos conhecidos. O conflito entre Mitilene e Metimna deveria inevitavelmente fazer o leitor se lembrar da revolta de Mitilene narrada no livro III de Tucídides (III.2-50), à qual se junta toda a Lesbos, com exceção de Metimna. ${ }^{33}$ Faz lembrar também a decisão dos atenienses de matar todos os homens da cidade que comanda a revolta (III.36.2); a revisão dessa decisão após os discursos de Cleão (III.3740) e de Diodoto (III.42-48); e como a segunda nau despachada pela cidade chega bem a tempo de impedir que a primeira decisão fosse cumprida (III.49.4). Grande parte do vocabulário tucididiano utilizado em Longo se concentra, não por acaso, no relato do conflito entre as duas cidades.

A guerra tem início em Dáfnis e Cloé, porém, com uma sequência de acontecimentos desimportantes que só acaba por envolver as duas cidades em um conflito bélico por causa das mentiras contadas pelos jovens metimnenses. Nisso, o episódio de Longo também contrasta com os dos demais romancistas - nada de revolta contra a tirania persa, como em Cáriton, ou ainda uma disputa entre dois países pelo domínio de minas de esmeralda, como em Heliodoro - e reafirma sua opção pela dimensão diminuta dos eventos. Jovens da cidade, que tinham ido ao campo caçar e se divertir, acabam por perder o seu barco porque um camponês que precisava de uma corda encontrou ocasião propícia para roubar aquela que prendia a embarcação à costa,

\footnotetext{
${ }^{33}$ Mason (2006, p.188) considera mais uma possibilidade que justifica o conflito entre as duas cidades: "other Greeks treated the lesbians, whose cities never achieved political unity, as paradigmatic of conflict and faction. This is a tradition that may be recalled in Longus' narrative of war between Mytilene and Methymna in book 3".
} 
que é então substituída por vime. Assustadas pelos cães dos jovens, as cabras de Dáfnis fogem para a praia e alimentam-se da planta que prendia a embarcação. Os jovens revoltam-se com a perda e culpam Dáfnis pelo acontecido, acabando por agredi-lo, mas os camponeses o socorrem e os dois lados exigem que seja feito um julgamento. Filetas é escolhido como juiz por ser o mais velho e por ser conhecido pelo seu caráter justo

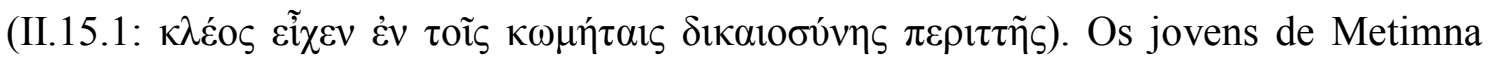
apresentam sua acusação, culpando Dáfnis por permitir que suas cabras chegassem até a praia e provocassem a perda do barco: "que roupas perdemos, que arreios para os cães, quanto dinheiro! Com ele daria para comprar até estes campos todos!". 34 Dáfnis contra-argumenta animado pela presença de Cloé, afirmando que os cães dos jovens ricos são mal treinados e se comportam como lobos: “O barco está perdido por causa do vento e do mar. Isso é culpa do mau tempo e não das cabras. Então havia roupas e dinheiro lá: mas que pessoa de bom senso acreditará que um barco que levava tanta riqueza usava um vime no lugar da corda?". ${ }^{35}$ Mas é o choro de Dáfnis que acaba por comover definitivamente Filetas - e, como nós, leitores, sabemos, a argumentação de defesa feita por ele é falha; de fato havia riquezas no barco perdido. O juiz decide a favor do pastor, julgando o "vento" como o culpado. Inconformados, os jovens da cidade têm de ser expulsos a pau e pedra.

Voltando feridos a Metimna, o narrador diz que eles não contam nada do que de

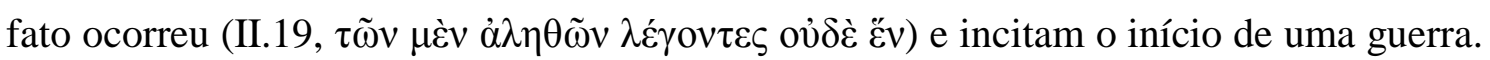
Sob o comando de Briaxis, eles pilham o campo de Mitilene e levam Cloé como prisioneira, enquanto Dáfnis se esconde dentro do tronco de uma árvore. Ele então se desespera e cobra das Musas a proteção que deviam a Cloé. Logo depois, elas aparecem em seu sonho e contam-lhe que, apesar de ele nunca ter prestado as devidas honras ao deus Pã, ele salvaria Cloé a pedido delas. Na sequência, Pã intervém primeiro por meio do pânico que atinge a tripulação e, logo depois, revela em sonho para Briaxis seu

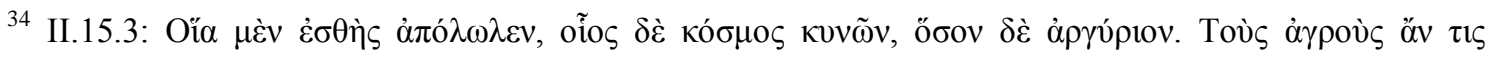

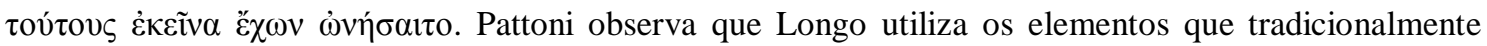
indicavam as riquezas transportadas em um navio, vestimentas e dinheiro (cf. Safo, fr.44), acrescentando a ele o detalhe insólito dos acessórios de couro dos cães (cf. Xen. Cyneg.7.6), um elemento realista " a tal punto insolito da indurre alcuni a dubitare della sua autenticită" (2005, p.325, n.57).

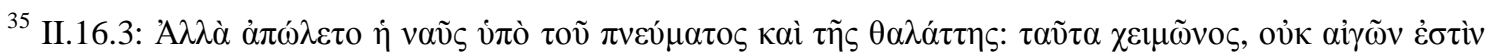

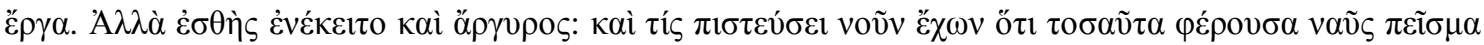

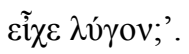


descontentamento com a atitude dos metimnenses. Ele ordena que a pastora e seus animais sejam libertados e o navio retorna magicamente à costa.

Vieillefond na edição Budé (1987) apontou diversas semelhanças entre o episódio e a narrativa da revolta de Mitilene em Tucídides, como o fato de as disputas terem sido tanto terrestres quanto navais e a ocorrência de pilhagem. Cueva (2004, p.58s) observa que esses paralelos são enfatizados por meio da fraseologia, quando no livro III o romancista faz ecoar a frase "e assim Mitilene escapou desse perigo"

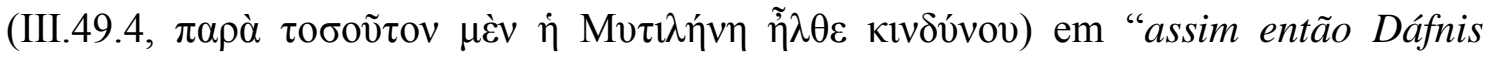

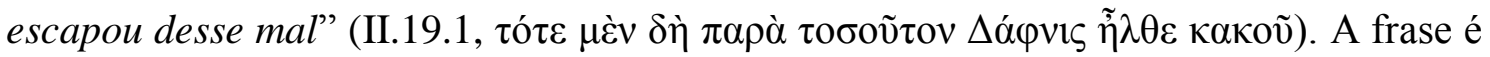
usada pelo historiador no clímax do episódio da revolta de Mitilene, quando a segunda nau dos atenienses chega para impedir que a decisão inicial de exterminar todos os homens da cidade fosse colocada em prática; a frase de Longo, por sua vez, é introduzida logo após o julgamento de Dáfnis e a expulsão dos jovens metimnenses pelos camponeses.

Para Cueva, isso sugere também que o leitor deve identificar o julgamento do pastor (II.15-16) com o debate entre Cleão e Diódoto e a decisão dos atenienses de apaziguar o seu ódio, uma relação que seria enfatizada pela presença do tema da

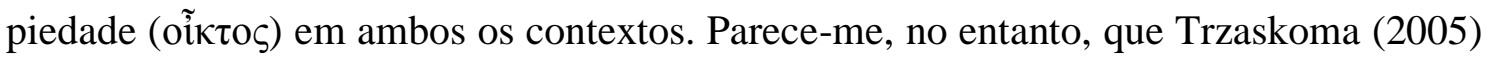
está correto ao apresentar argumentos contrários a essa leitura. Em primeiro lugar, Cueva superestima a importância da piedade no discurso de Diódoto, e é relevante o fato de que os contextos são muito diferentes - em Longo, no início do conflito, em Tucídides perto de encerrá-lo - e de que a alusão em II.19.1 é atenuada pelo fato de uma estrutura sintática semelhante ter aparecido na narrativa quando Dórcon consegue se

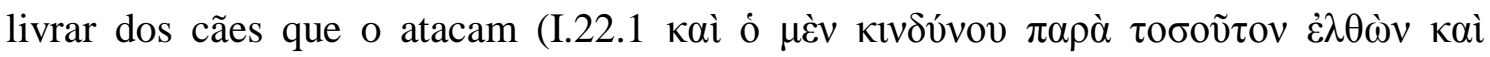

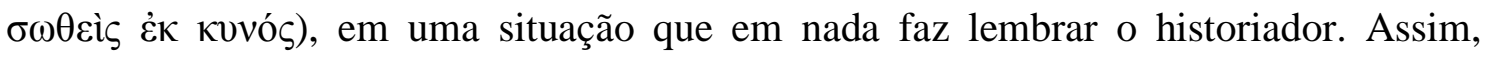
parece fazer mais sentido entender que é na decisão dos cidadãos de Mitilene em não dar prosseguimento ao conflito, retribuindo o ataque sofrido em sua zona rural, que Longo reelabora a mudança de perspectiva dos atenienses sobre qual medida lhes seria mais proveitosa (III.1).

No início do livro III, sabendo do que havia acontecido no campo, os homens da cidade de Mitilene decidem enviar uma armada para responder ao ataque de Metimna, sob o comando de Hípaso. Como em Metimna, ao mesmo tempo, esclarece-se o real motivo pelo qual os jovens haviam aparecido feridos depois de sua viagem ao campo, os metimnenses decidem apresentar uma proposta de paz, aceita por Mitilene. 
Trzaskoma argumenta que é nesse trecho que mais claramente se faz presente a relação com Tucídides; com efeito, trata-se de um parágrafo em que o estilo do texto se altera de forma radical. ${ }^{36}$ Macqueen (1990, p.64) faz uma boa comparação, ao dizer que o efeito estético dessa mudança de estilo equivale a uma orquestra de câmara que tocava Vivaldi e repentinamente passa a tocar Beethoven, voltando a Vivaldi logo depois. ${ }^{37}$

Trzaskoma sugere que, com isso, Longo insinua ao leitor, bem no meio da narrativa, uma espécie de segundo proêmio que confirmaria uma impressão criada inicialmente - por meio da afirmação da utilidade da narrativa - de que o romance desenvolveria o tema tucididiano da guerra. A interrupção do desenrolar dos eventos entre Mitilene e Metimna refletiria, por um lado, a mudança de disposição dos atenienses em punir a cidade de Mitilene pela rebelião e, por outro lado, deliberadamente explicitaria a liberdade de Longo no que diz respeito às convenções do gênero romanesco. Trzaskoma afirma que o episódio é "praticamente irrelevante para o romance como um todo" por se tratar de uma história de amor (idem, p.85) e que Longo só o introduz para "apontar sua irrelevância" (idem, p.82):

Os personagens às vezes aparecem, desaparecem e depois voltam mais tarde, mas por um propósito. Dórcon ajuda a salvar Dáfnis, então reaparece para competir contra Dáfnis por um beijo de Cloé (e, como isso não dá certo, para pedir sua mão e depois tentar violentá-la) e finalmente para ser morto pelos piratas. Porém, cada uma dessas aparições afeta diretamente o herói e a heroína e é logicamente completa em si mesma. A narrativa de guerra no início do livro 3 não serve a nenhum outro propósito além de introduzir a ideia de que a guerra foi menos dolorosa para Dáfnis e para Cloé do que o inverno.

Sua conclusão é de que o autor utiliza Tucídides de modo irônico, como uma espécie de "declaração de independência" da historiografia (idem, p.86), cujas estratégias são muito utilizadas por romancistas como Cáriton e o autor de Nino, que dessa forma demonstrariam sua "falta de autoconfiança". Embora Longo não coloque o

\footnotetext{
${ }^{36}$ Cf. Cueva (2004, p.60), para uma lista de termos tucididianos na passagem.

37 Pattoni (2005, p.366, nota 1) observa forte redução de quiasmos, paralelismos, aliterações e assonâncias.
} 
tema da guerra em posição central como fazem os outros dois romancistas, acredito que seria um pouco irônico demais - mesmo para Longo - desenvolver o episódio em uma porção da narrativa que ocupa oito páginas de uma edição da Teubner (que tem no total sessenta e cinco), apesar de considerá-lo irrelevante, com o único propósito de expressar uma recusa do tema. De fato, dada a clara intenção do autor de se filiar à poesia bucólica que floresceu entre os alexandrinos, é natural que se espere uma oposição entre amor e guerra e a escolha do primeiro como tema a ser plenamente desenvolvido. Parece-nos que isso é marcado também pela mencionada alteração do estilo no início do livro III; o narrador assume uma postura tucididiana justamente porque o conflito bélico entre duas cidades não pode ser tratado com a mesma linguagem de uma narrativa bucólica. Trata-se da "intrusão" de outro gênero em Dáfnis e Cloé - da historiografia que subordina o estilo empregado pelo autor, marcando a guerra como elemento estranho ao campo e aos pastores. Porém, como se discutirá a seguir, o papel de Pã no resgate de Cloé, deus associado a Dáfnis ao longo de todo o romance, dá à guerra função importante, que vai além de uma presença justificada meramente pelo desejo do autor de dar tratamento irônico a convenções genéricas. Nesse sentido, ainda que o episódio seja abruptamente interrompido, ele tem desenvolvimento suficiente no livro II para que Trzaskoma considere apenas o trecho inicial do livro III na sua conclusão de que a guerra é irrelevante na economia da narrativa.

Outro argumento do crítico é que o conflito deve ser entendido como desimportante porque, logo após sua conclusão, o narrador diz que a chegada do inverno foi, para Dáfnis e Cloé, pior do que a guerra (III.3.1). Ele deve, porém, ser visto em paralelo com os fatos já mencionados de que Dórcon, o primeiro agressor de Cloé, é afinal retratado com simpatia e recebe dos dois amantes honras fúnebres e que Lâmpis, o segundo agressor, aparece tocando flauta no seu casamento. Nem por isso as ameaças de agressão sexual sofridas por Cloé foram consideradas irrelevantes. Por outro lado, logo após o episódio dos piratas, o narrador faz um comentário encerrando o livro I que lembra o tom irônico da comparação entre a guerra e o inverno (I.32.5):

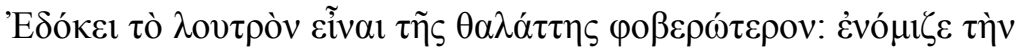

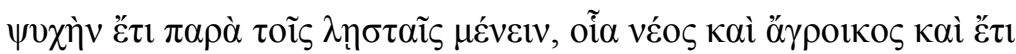

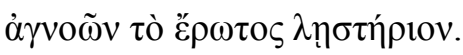


O banho parecia ser mais temerário do que o mar; julgava que sua vida ainda estava nas mãos dos piratas, tão jovem era, rústico e ainda ignorante da pirataria do amor.

A frase é inserida no momento imediatamente posterior ao banho de Cloé, que ao ser observado por Dáfnis, causa-lhe enorme angústia pela visão da beleza da menina. Como se pode observar, em ambos os casos, os episódios de violência são colocados em comparação com os males de amor - no caso do inverno, porque os camponeses permanecem em suas casas, o que impede o encontro frequente do casal. O fato de que a guerra pareça menos dolorosa do que a mudança de estação ao par de amantes deve ser entendido como ênfase na dor da distância por ele provocada - de fato, o único evento na narrativa que os separa por um breve período -, já que eles passam apenas uma noite longe um do outro no episódio bélico. Vistos em paralelo, os dois comentários irônicos do narrador não apresentam uma recusa à temática da guerra e da pirataria, que são desenvolvidas no romance ainda que em proporções relativamente menores, mas em ambos os casos Longo enfatiza sua opção de não se valer de um tema central para o gênero romanesco: trata-se da ausência da viagem em sua narrativa e a consequente separação dos amantes em aventuras paralelas. Um trecho citado por Anderson (1982, p.47) como um dos vários momentos cômicos do romance de Longo, aquele em que Dáfnis, desesperado pelo rapto de Cloé, imagina que "o pior que poderia acontecer a ela" seria viver na cidade, para além de expor a ingenuidade do pastor, toca na possibilidade de Cloé ser afastada da sua família e do local onde vive, o que é, de fato, a pior coisa que acontece a uma heroína nos romances gregos.

Com efeito, não se pode afirmar que os piratas sejam irrelevantes ou que deixem de fazer o que eles vêm ao campo fazer, afinal Dáfnis é raptado e Dórcon é morto por eles. O que se aborta na narrativa é aquilo que o leitor familiarizado com as convenções genéricas esperaria: a venda do jovem pastor em um local distante da ilha de Lesbos, como acontece, por exemplo, com Calírroe após ser raptada por Téron. O mesmo se dá com a guerra: tudo parece caminhar para um confronto militar entre os exércitos das cidades de Metimna e Mitilene, pois o que Pã interrompe não é a guerra (cujo fim é decidido pelos cidadãos de Mitilene reunidos em assembleia), mas o destino de Cloé como escrava na cidade, pois apenas ela e seus animais são resgatados do barco metimnense e devolvidos ao campo. Aliás, é só pela ação de Pã, explicitamente associado a Dáfnis ao longo do romance, que a história de amor de Cloé pode ser 
retomada - e trata-se do único momento na narrativa em que se descreve uma manifestação do deus, cuja representação está nesse caso em claro contraste com sua ação nos mitos embutidos. Com todos esses elementos, será mesmo que o episódio bélico de Dáfnis e Cloé pode ser considerado insignificante?

\section{III.4 O aprendizado da guerra e da violência}

Trzaskoma, contudo, não é o único a perceber uma recusa do tema da guerra em Longo. Pelo contrário, nota-se que há uma tendência na crítica em observar, por um lado, uma violência no romance que é tratada de tal forma que faz avançar a educação sexual e social do par amoroso central e, por outro lado, dois episódios (a invasão dos piratas no livro I e o episódio bélico do livro II) que teriam pouca ou nenhuma função na estrutura geral do romance e apenas demonstrariam uma atitude irônica do autor no que diz respeito aos episódios convencionais do gênero. Entre as diversas observações que faz sobre a comicidade da narrativa, Anderson (1982) ressalta que os cidadãos de Mitilene decidem não dar continuidade à guerra por ser "mais barato" desse modo (a palavra utilizada é $\kappa \varepsilon \rho \delta \alpha \lambda \varepsilon \omega \tau \varepsilon ́ p \alpha$, III.2.5). Hilton (2005, p.69), no artigo que analisa o tema da guerra no romance, chega à conclusão de que Longo "rejeita implicitamente a guerra e a violência" porque elas são intrusões no mundo idílico pastoral. A guerra é uma força que perturba o equilíbrio da vida no campo: "a intervenção dos poderes da natureza manifestados em Pã são necessários para restabelecer a harmonia". À mesma conclusão havia chegado Effe (1999, p.201), que considera os episódios da guerra e da invasão dos piratas elementos significativos da oposição temática campo idealizado $v s$. realidade urbana: "por motivo fútil, pela negligência urbana e pelo prazer da caça, a guerra cai sobre os pastores com toda a brutalidade possível. [...] Graças à intervenção milagrosa de Pã, Cloé é libertada e o mundo pacífico e feliz dos pastores é restaurado". O narrador, porém, faz questão de ressaltar que Pã não é responsável pelo restabelecimento definitivo da paz, mas apenas pelo resgate de Cloé e de seus animais.

Mesmo Lalanne (2006), na sua análise sobre os ritos de passagem que o jovem par amoroso dos romances gregos enfrenta em seu desenvolvimento até o momento em que estariam aptos a assumir seus devidos papéis sociais, não vê função significativa no episódio bélico criado por Longo. Ao contrário, julga notável que as etapas decisivas de 
formação de Dáfnis sejam totalmente discrepantes do que se pode observar nos demais romances. Assim (idem, p.165),

\begin{abstract}
A guerra contra Metimna no livro II passa ao segundo plano diante da lição fortuita de Filetas sobre o amor; o rapto de Cloé pela frota dos Metimnenses e seu resgate por Pã têm, do ponto de vista da narração, o estatuto de uma simples peripécia em comparação com a grande cena de festivais pastoris que se seguem ao retorno da jovem. Em suma, as provações especificamente romanescas são ofuscadas pelo percurso sentimental e sexual que deve levar o herói à idade adulta.
\end{abstract}

Morgan (2004, p.186), por sua vez, é um dos poucos que percebe diversas funções na guerra entre Metimna e Mitilene, ainda que elas não sejam centrais na narrativa. Além de interromper o curso de descobertas sexuais de Dáfnis e de Cloé: a) o episódio é espelhado nos eventos do livro I.28, quando Dáfnis é raptado pelos piratas e milagrosamente libertado, criando-se, assim, uma simetria nas aventuras vividas por cada um dos jovens; b) a educação de Dáfnis e de Cloé não é apenas sobre amor e sexo, mas também sobre o divino; c) trata-se do primeiro episódio a explorar a relação entre campo e cidade, a guerra sendo um elemento que invade a paz do campo; d) o tema é tratado como paródia de um elemento recorrente no romance; e e) a narrativa faz lembrar eventos narrados por Tucídides, de modo que Longo contrasta o mundo idílico com a Realpolitik do século V a.C. e a decisão de Atenas de executar toda a população masculina em Mitilene.

Parece-nos que Morgan, ao chamar a atenção para a aprendizagem religiosa do par amoroso, toca no ponto essencial da guerra para a estrutura geral da narrativa, que é a atuação de Pã e o fato de que Dáfnis passa a lhe prestar as devidas honras a partir desse momento. Não é por acaso que as Ninfas enfatizam que Dáfnis nunca o havia honrado, ainda que o pastor tenha demonstrado saber quem ele é anteriormente na narrativa (cf. I.16.3). De fato, outros heróis romanescos passam por uma guerra, seja como líder vitorioso, no caso de Quéreas, como prisioneiro, no de Teágenes, ou como observador, no de Clitofonte, mas Dáfnis sequer presencia um confronto; ele apenas observa uma pilhagem, escondido dentro de uma árvore. Isso não precisa significar, 
porém, que a experiência é irrelevante para o pastor, uma vez que a relação que se estabelece entre ele e o deus Pã é recorrente e significativa no romance.

Nas histórias míticas contadas por personagens ao longo do enredo, a presença de Pã é uma constante. Desde antes da célebre análise de John Winkler (1990) do romance de Longo como uma narrativa na qual se representa a educação de Cloé sobre a sexualidade humana como produto de uma construção social e cultural da qual faz parte a aceitação pela mulher da violenta dominação masculina, os críticos reconhecem nas narrativas míticas etiológicas contadas por personagens ao longo do enredo uma violência crescente que se associa à evolução do conhecimento do par central sobre sexo e a aproximação do momento em que Cloé perderá a virgindade. ${ }^{38}$ Winkler (idem, p.104) argumentou que Cloé ao longo da narrativa será educada a perceber que o mundo ao seu redor é "organizado pela ideia da vulnerabilidade feminina".

De fato, se há "comicidade burlesca" no modo pelo qual Longo escolhe introduzir as cenas de violência sofridas pelos personagens, ela contrasta, porém, com a violência encontrada nos mitos sobre Pã narrados por eles. Os três têm aspectos em comum: todos são etiológicos e contam a história de uma bela e jovem donzela que por força de uma ação agressiva masculina sofre uma metamorfose - e nesse processo a música tem papel fundamental. ${ }^{39}$ No livro I (I.27), em um momento em que Dáfnis e Cloé ainda não haviam tido nenhuma das lições sobre o amor, eles ouvem o canto de um pombo-torcaz ( $\varphi \alpha ́ \tau \tau \alpha)$ e a menina pergunta sobre seu significado. Dáfnis então lhe

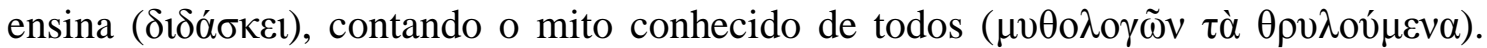
Trata-se da história de uma jovem pastora que por meio do canto guiava seu rebanho, sem necessidade de cajado ou aguilhão, "mas sentada sobre um pinheiro com uma coroa de pinhas na cabeça, ela cantava sobre Pã e Pítis e as vacas ficavam onde pudessem ouvir sua voz". ${ }^{40}$ Essa jovem, porém, sofreu um dia com a competição de um

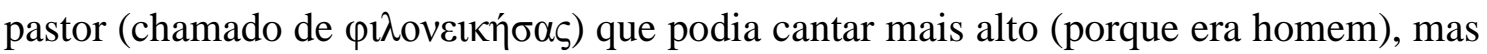
de forma doce (porque era um menino) e, com isso, ele conseguiu roubar oito de suas vacas. Triste pela perda dos animais e pela derrota, ela pediu aos deuses para ser transformada em pássaro e até hoje canta sobre sua tristeza, enquanto procura as vacas que a deixaram.

\footnotetext{
${ }^{38}$ Cf. também Konstan (1994, p.79-90), Goldhill (1995, p.30-45) e Epstein (2002).

${ }^{39}$ Sobre o papel da música em Dáfnis e Cloé, cf. Maritz (1991).

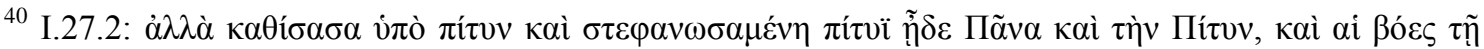
$\varphi \omega v \tilde{n} \pi \alpha \rho \varepsilon ́ \mu \varepsilon v o v .$. A única versão da história de Phátta que conhecemos é esta de Longo.
} 
No livro II (II.34), quando o casal já havia recebido de Filetas a lição sobre o amor, após o resgate de Cloé da nau dos metimnenses, há festejos que servem de ocasião para a narrativa do segundo mito embutido, a história de Pã e Siringe. Ela é contada por Lâmon, pai adotivo de Dáfnis. A siringe não era a princípio um instrumento, mas uma bela donzela com música em sua voz. Ela era pastora de cabras e brincava com as Ninfas. Um dia, quando ela estava pastoreando, brincando e cantando, Pã tentou convencê-la a ceder ao seu desejo, mas ela riu de seu amor e disse que não aceitaria um amante que não era totalmente nem homem nem bode. Pã decidiu tomá-la

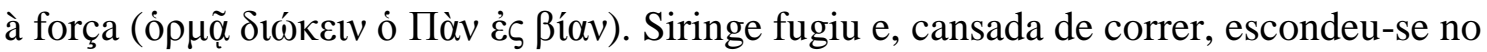
meio de caniços. Com raiva, Pã cortou-os e, sem conseguir encontrar a moça e percebendo o que havia acontecido, criou o instrumento, unindo com cera os caniços de tamanhos desiguais, pois o amor deles havia sido desigual. E aquela que outrora fora

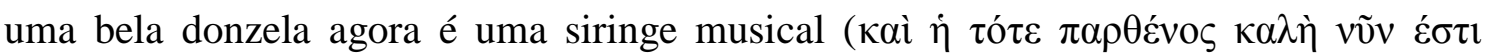

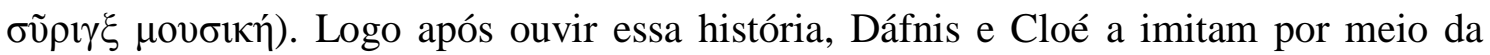
dança e, ao final, o menino recebe como presente a siringe de Filetas.

O último mito embutido é narrado no livro III (III.23), depois que Dáfnis já havia recebido a lição de Licénion sobre sexo. Ao ouvir um grupo de pescadores que remavam um barco em direção à cidade, Cloé percebe pela primeira vez um eco. Desconcertada, ela pergunta a Dáfnis se atrás do promontório havia outro navio com outros marinheiros. Ele então conta a ela que há três tipos de Ninfas, as Męíaı (Melíai), as $\Delta \rho v \alpha ́ \delta \varepsilon \varsigma$ (Dríades) e as "E $\lambda \varepsilon 101$ (Heleioi) ${ }^{41}$ Eco, filha mortal de uma ninfa, havia sido criada pelas Ninfas e ensinada pelas musas a tocar a siringe e o aulós. Quando chegou

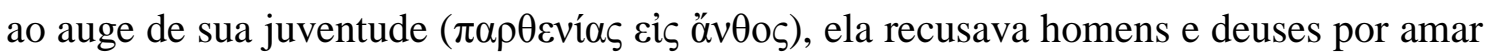

\footnotetext{
${ }^{41}$ A menção aos três tipos de Ninfas por Dáfnis é problemática. Cueva (2004) sugere a seguinte distinção: As Médııı são, de acordo com Hesíodo (Teog.182-85), as ninfas nascidas do sangue de Urano. As $\Delta \rho v \alpha ́ \delta \varepsilon \varsigma$ são ninfas de árvore e as "E $\lambda \varepsilon 10$, conhecidas apenas por essa menção feita por Longo, tomam um epíteto de Ártemis em Cos ( † Đ E $\lambda \varepsilon i ́ \alpha)$, o que reforçaria e lembraria o leitor do fato de que Cloé, como as outras donzelas dos mitos, é uma virgem que sofrerá uma espécie de violência. A leitura de Morgan

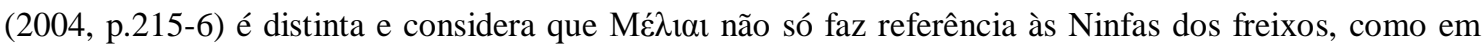
Hesíodo (aqui identificada com a Siringe, que teria se escondido nos freixos), mas também ao termo $\mu \varepsilon \dot{\lambda} \eta$ (melodias/membro). Morgan, em seu comentário (2004), aceita e elabora a sugestão de Blanchard (1975) de que as três ninfas que aparecem ao longo do romance para Dáfnis e Cloé são as mulheres dos mitos etiológicos: as heroínas se tornam imortais, e retornam para guiar a pastora por meio da mesma traumática, mas necessária e benevolente, experiência pela qual elas próprias passaram. Parece-me que não há no texto, porém, nenhuma passagem que corrobore essa leitura.
} 


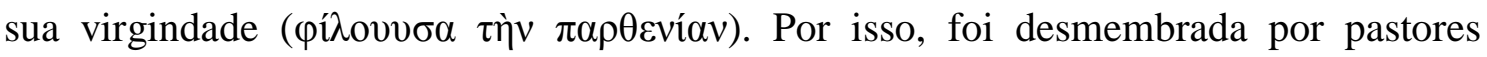
enlouquecidos por Pã, que se ressentia da sua rejeição e da sua habilidade musical. Por amor às Ninfas, Terra escondeu todas as partes do seu corpo e os locais onde elas se encontram agora emitem uma voz capaz de imitar tudo: homens, deuses, animais e instrumentos musicais.

Os críticos tenderam a analisar os mitos na sua relação com o enredo principal como histórias que no todo refletem ou contrastam com o que estão vivendo Dáfnis e Cloé, mas nos parece que o texto sugere ora uma, ora outra atitude, sem que elas sejam necessariamente excludentes. ${ }^{42}$ Está claro que eles têm uma função educativa na trama ${ }^{43}$ e a violência que neles se faz presente parece substituir à maneira de Longo aquela que os casais de outros romances enfrentam em suas aventuras pelo Mediterrâneo. Trata-se de um aprendizado pela palavra, e não pela experiência, o que reproduz o próprio modelo pedagógico do enredo como enunciado no proêmio: afinal, o que teremos quando a história estiver completa é mais um mito, o de Cloé. Não por acaso, no último e quarto livro não há qualquer narrativa embutida, como há nos três anteriores, e o romance se encerra com a metamorfose esperada desde o início, a de Cloé, que de

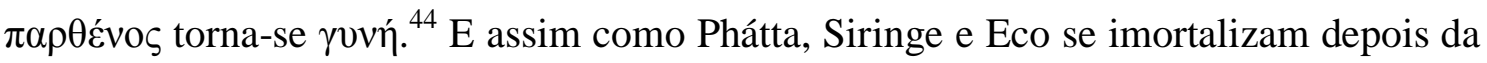
transformação, o mito de Cloé será o "patrimônio agradável” e eterno criado por Longo.

Na primeira narrativa, a presença de Pã é marcada apenas por meio de alusões; a jovem pastora senta-se sob o pinheiro e canta coroada de pinhas. Além disso, Dáfnis diz que seu canto era sobre Pã e Pítis. O amor de Pã pela ninfa Пítv̧ explica sua associação com o pinheiro ( $\pi i$ ivऽ). As únicas versões mais elaboradas do mito são posteriores a Longo, registradas em Nonno (Dion.42.-258-60) e na obra bizantina Geoponika (11.10). ${ }^{45}$ Na primeira, Pã é um amante rejeitado, mas a segunda envolve, como nos outros dois mitos embutidos, a perseguição de uma personagem feminina e sua

\footnotetext{
${ }^{42}$ Um exemplo da primeira atitude é a análise de Chalk (1960), para quem os mitos ressaltam aspectos que estão de acordo com o estágio do desenvolvimento sexual de Dáfnis e Cloé no momento em que são contadas. Philippides (1980), por sua vez, faz excelente análise em que vê contraste entre os mitos e a história dos protagonistas. Sobre os mitos, cf. também Hunter (1983, p.52ss), Macqueen (1990, p.31ss), Winkler (1990), Goldhill (1995, p.44ss), Cheyns (2001) e Cueva (2004, p.44ss).

${ }^{43}$ Cf. I.27.1 e III.22.4, em que isso é dito de forma explícita.

${ }^{44}$ Macqueen (1990) tem uma leitura diferente e considera como "mito de Cloé" não todo o romance, mas apenas o que acontece no livro IV: seu rapto por Lâmpis, o resgate e o casamento.

${ }^{45}$ Cf. Borgeaud (1988, p.78) e Morgan (2004, p.172).
} 
metamorfose: Pítis era também amada por Bóreas que, preterido por Pã, matou-a, quando então ela se transformou em árvore. Embora não seja possível saber os detalhes do mito do amor de Pã e Pítis a que Longo alude, não é muito provável que fosse a essa versão, já que o deus não exerce nela o mesmo papel dos outros dois mitos, em que persegue Siringe e Eco. Quanto aos eventos principais do mito, a ausência de elementos violentos no início do livro I parece refletir no relato de Dáfnis sobre Phátta e, por outro lado, eles anunciam o roubo dos animais de Dórcon pelos piratas que acontecerá logo em seguida (I.28). Ao narrar um mito em que são centrais a competição e a disputa (vencidas pelo menino apenas por meio do canto), revela-se que Dáfnis ainda está num estágio de desconhecimento tanto da violência que vivenciará posteriormente quanto de Eros, dois elementos marcantes nos mitos seguintes. Sua ignorância havia sido demonstrada pouco antes, quando ele entende a investida de Dórcon sobre Cloé como uma brincadeira de pastor.

Longo, acredito, ressalta o caráter pedagógico desse mito ao demonstrar que ele tem um "resultado prático" quando o narrador diz que Cloé, durante o ataque dos piratas, por ser uma menina conduzia o seu gado mais lentamente por causa do medo

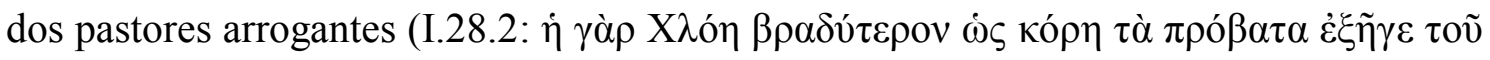

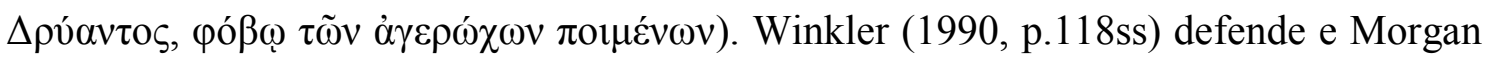
(2004, p.173) coloca como hipótese que essa atitude de Cloé pode sinalizar que o ataque de Dórcon teve, sim, como resultado deixá-la mais precavida com relação aos homens. Mas me parece possível também que sua precaução seja resultado do fato que ela acabara de ouvir o mito de Phátta, que entende como lição não apenas sobre a origem do pombo-torcaz, mas da sua própria fragilidade como menina - e é significativo que sua demora em conduzir o rebanho seja aquilo que, de fato, impeça que ela sofra na mão dos piratas, diferentemente do que acontece a Dórcon e a Dáfnis. A identificação entre Phátta e Cloé é marcada várias vezes, desde a forma como Dáfnis inicia sua narrativa

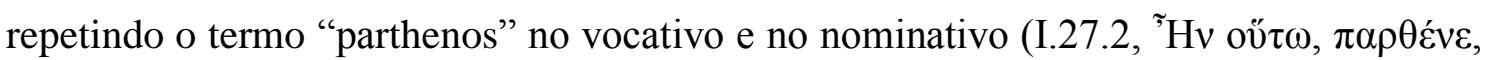

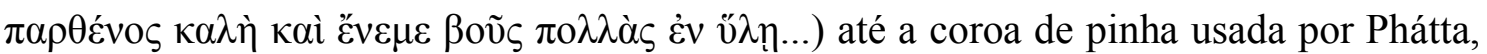
algo que a relaciona a Pã e também a Cloé, que pouco antes aparecera com o mesmo objeto sobre a cabeça (I.23.3) e com o qual ela aparecerá mais uma vez, quando Pã for resgatá-la do barco metimnense (II.26.2). Assim, o mito enfatiza a posição de vulnerabilidade de Phátta e, consequentemente, da heroína.

Em contraposição ao mito, porém, a relação entre ela e Dáfnis é de harmonia e cooperação: Phátta perde seus animais porque o menino é melhor cantor, mas é por 
meio da música que Cloé possibilitará a salvação de Dáfnis das mãos dos piratas. Podemos observar essa simultaneidade de identificação e de oposição também no relato da história de Siringe. Como observa Cheyns (2001, p.173), diferentemente da versão de Ovídio (Met., I.689ss), a Siringe de Longo não é uma ninfa, mas “uma jovem que também guarda um rebanho, que tem relações familiares com as Ninfas, e que canta para imitar os pássaros. Longo considera, portanto, que a história de Siringe como um infortúnio que poderia acontecer a Cloé". Contada logo após o resgate de Cloé, a história reflete a atuação de Pã e a importância da música na manifestação do deus aos soldados metimnenses.

Se Pã é um deus importante nos mitos que de alguma forma educam Dáfnis e Cloé, disso resulta, como observa Lalanne (2006, p.164), que “Dáfnis é posto sob a patronagem de um deus violador de Ninfas, adepto de uma sexualidade brutal e tirânica". A observação de Epstein (2002, p.34) é, no entanto, oportuna: Dáfnis intui, quando junto com Cloé os dois imitam por meio da dança o mito de Pã e Siringe que haviam acabado de ouvir, que o homem deve ter um papel agressivo com relação à mulher, mas que a violência demonstrada no mito não tem lugar no mundo humano - a cena final, quando Pã mata Siringe transformada em caniço, não chega a ser representada, mas Dáfnis passa a tocar o instrumento logo depois que Cloé se esconde. Ainda que Dáfnis deva honrar Pã, como lhe ensinam as Musas, e que o narrador force a identificação entre os dois, sua agressividade sexual não é aceitável no plano humano. Desse modo, o que ensina o mito, nas palavras de Cheyns (2001, p.175) é que

\begin{abstract}
A siringe não permite apenas reunir o gado nem provocar uma rivalidade funesta; ela é também capaz de atrair a mulher desejada, mas sob a condição de que o homem renuncie a toda violência e que Eros os una em um amor de igual intensidade.
\end{abstract}

É o que se pode observar de outro modo no mito de Eco. Contada novamente por Dáfnis, a terceira história embutida o coloca mais uma vez em posição de ensinar Cloé, mas dessa vez isso também sinaliza que ele se tornou mais experiente que ela nos assuntos eróticos, depois de ter recebido a lição de Licénion. Aqui de novo se faz presente a violência do desejo sexual de Pã, sua rejeição e sua fúria, manifestada, como 
no pânico provocado nos soldados, na perturbação que pode causar nos homens. ${ }^{46}$ Por sua vez, o apego de Eco à virgindade e sua destruição por causa disso revelam que permanecer virgem não é o destino apropriado para uma moça. Com efeito, Eros é a divindade central em Longo e a recusa de Eco pode ser entendida como algo que desestabilizaria sua harmonia. ${ }^{47}$ Por outro lado, as paixões frustradas de Pã, chamado frequentemente de $\delta$ $\sigma \varepsilon \rho \omega \varsigma$, infeliz no amor, demonstram que "os poderes de Afrodite, quando mediados por Pã, são postos em uma ambientação que nega seu propósito último: o casamento. A sexualidade de Pã [...] é, por definição, não familiar $e$ selvagem" (Borgeaud, 1988, p.77).

Não é sempre que a crítica levou em consideração o fato de que entre o primeiro e o segundo mitos ocorre a intervenção de Pã na pilhagem dos metimnenses, portanto, antes que o deus seja apresentado como um "violador de ninfas". Que o mesmo deus Pã presente nos três mitos tenha papel central na libertação da heroína quando ela é levada como prisioneira foi algo entendido muitas vezes apenas como representação das forças da natureza afastando do campo uma violência urbana e reestabelecendo a paz que lhe é característica, como já se afirmou. Creio, contudo, que a presença do deus indique que o episódio também faz parte da educação do herói - e não apenas no seu aspecto religioso, como considera Morgan (2004, p.186). Relegados ao segundo plano, os piratas e a guerra parecem dizer respeito a uma esfera mais ampla do papel social masculino - cujo aspecto privilegiado por Longo é o relacionamento erótico -, que Dáfnis deverá assumir na sua passagem à idade adulta.

Quando do ataque dos piratas tirrenos, Pã de alguma forma influencia o desenrolar de eventos por estar associado à música dos pastores, artifício pelo qual Cloé consegue induzir o movimento das vacas, do que resulta o naufrágio do barco e a salvação de Dáfnis. Depois, ele se apresenta no ataque de pânico dos soldados de Metimna, um fenômeno alucinatório associado ao deus, e que ocorria em geral à noite e

\footnotetext{
${ }^{46}$ Blanchard (1975, p.175): "Ce texte met en évidence un aspect bien particulier de la puissance de Pan, à savoir la panolepsie, qui est la possession soudaine et violente par le dieu d'un individu, qui se trouve ainsi projeté hors du réel et peut même, devenu complètement furieux, attaquer ses semblables et les déchirer comme une bête enragée".

${ }^{47}$ Cf. Philippides (1980, p.197).
} 
em contexto militar. ${ }^{48}$ A manifestação de Pã tem início no momento em que o navio havia navegado dez estádios e o capitão decide ancorar em um promontório. Os soldados bebem e festejam, mas ao cair da noite, a terra parece-lhes estar em chamas e eles começam o ouvir o que parece ser o som de uma grande frota avançando sobre eles e depois os atacando. "Seria possível julgar que se observava uma batalha noturna, não

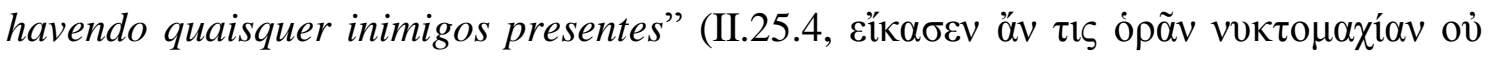
$\pi \alpha \rho o ́ v \tau \omega \nu \pi \circ \lambda \varepsilon \mu i ́ \omega v)$. Ao amanhecer, os animais de Dáfnis têm nos chifres heras cheias de frutos, os de Cloé uivam como lobos e ela mesma aparece coroada de pinhas. Não se consegue levantar as âncoras, os remos quebram ao tocar a água e os golfinhos atacam os navios. Ouve-se o som da siringe e ela não traz alegria, mas medo, como a trombeta $\left(\sigma \alpha \lambda \pi^{\prime} \gamma \xi\right)$, um instrumento militar.

Embora estivesse claro que os eventos eram resultado do descontentamento de Pã, os metimnenses não entendiam o seu motivo, até que o capitão Briaxis tem um sonho com o deus (II.27):

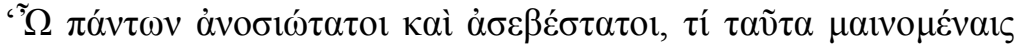

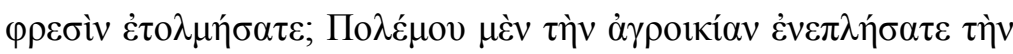

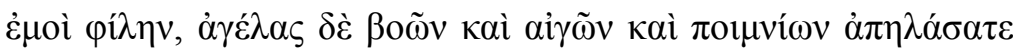

\footnotetext{
${ }^{48}$ Sobre a atuação militar de Pã por meio do pânico e da possessão, cf. Borgeaud (1988, p.88ss). A ele foi atribuída a ideia de dispor o exército em alas e fileiras. A melhor descrição de um ataque de pânico é feita por Pausânias (10.23.7-8) quando relata aquele sofrido pelos gauleses após sua derrota em Delfos: "Durante a noite, cai sobre eles o terror chamado Pânico: pois dizem vir dele [de Pã] os pavores que não têm nenhum motivo. A perturbação começou no exército por volta do momento em que era profunda a noite, e a princípio poucos foram os fora de si. Eles achavam que podiam ouvir o barulho de cavalos avançando sobre eles e o ataque de inimigos. Em pouco tempo, a loucura espalhou-se por todos. Tomando então as armas e separando-se, mataram os outros e, por sua vez, eram mortos sem reconhecer

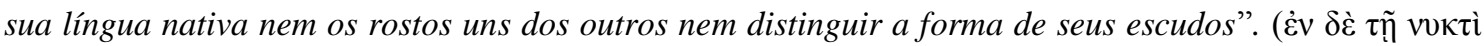

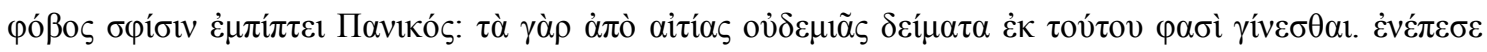

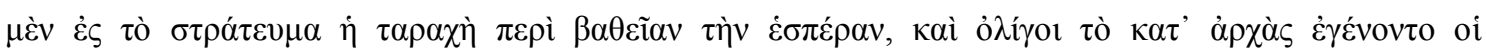

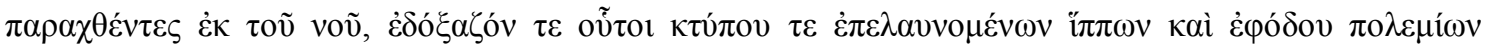

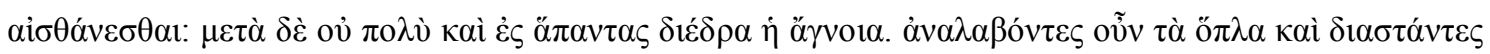

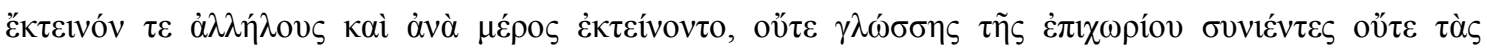

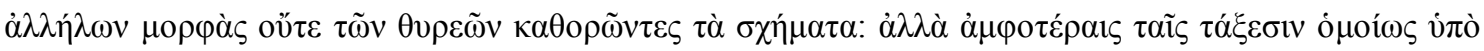

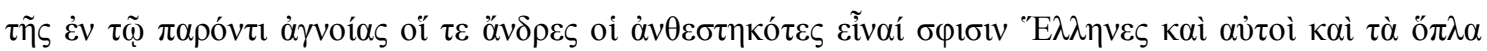

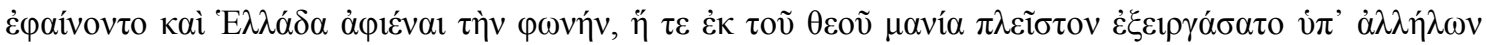

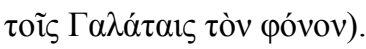




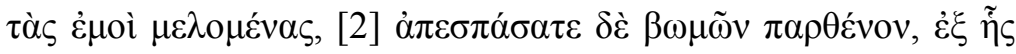
"Е

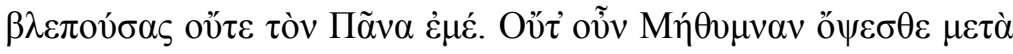

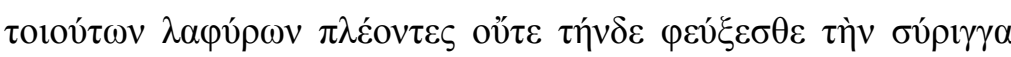

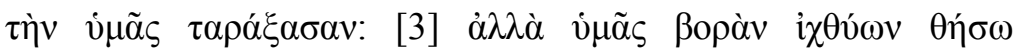

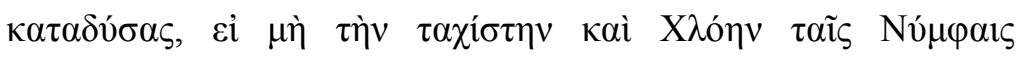

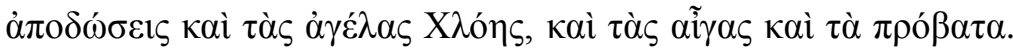

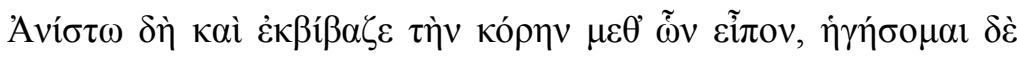

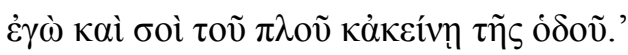

"Como vocês, os mais sacrílegos e ímpios de todos os homens, puderam ousar fazer essas coisas nos seus corações enlouquecidos? Com a guerra vocês encheram o campo que me é caro; levaram embora rebanhos de bois, cabras e ovelhas protegidos por mim; vocês arrastaram dos altares uma donzela, da qual Eros deseja fazer um mito; e nem as Ninfas, que tudo observavam, nem a mim vocês respeitaram. Então vocês nunca verão Metimna de novo se navegarem com esses espólios nem fugirão desta siringe que os deixou perturbados. Mas depois de afundar seu navio farei de vocês comida de peixes, a não ser que vocês devolvam Cloé para as Ninfas imediatamente, e os animais para Cloé, tanto as cabras quanto as ovelhas. Acorde agora, deixe a donzela na praia com os animais que mencionei e eu serei o seu guia na viagem, e o dela em seu caminho".

Os eventos são descritos com detalhe pelo narrador, mas após o seu retorno, é a Cloé que cabe a função de relatar o que se passara no barco a Dáfnis, no único momento do romance em que a garota se torna narradora de uma história sobre Pã (II.30.3):

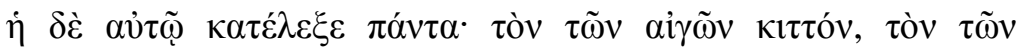

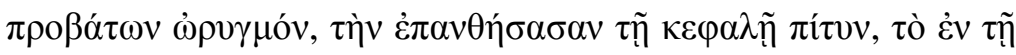

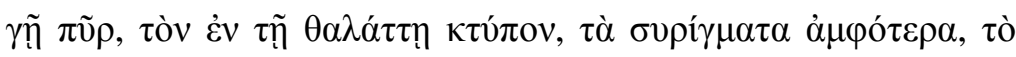

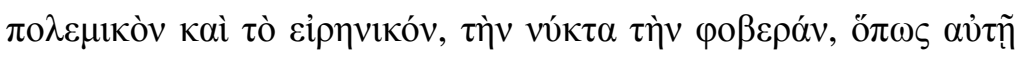

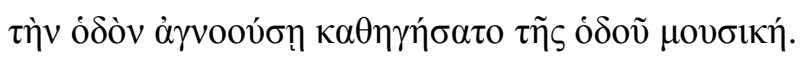


Ela contou-lhe tudo: a hera nos bodes, o uivo das ovelhas, a pinha que apareceu em sua cabeça, o fogo na terra e o barulho no mar, os dois tipos de som de flauta, um marcial, outro pacífico, a noite de terror, e como, quando ela não sabia o caminho, a música mostrou-lhe o caminho.

Ao ouvir esse relato, Dáfnis percebe que tudo fora obra de Pã, como as Ninfas haviam-lhe anunciado e, por sua vez, ele próprio conta a Cloé o que se passara com ele em terra durante o seu rapto. É apenas depois dessa intervenção benéfica que os mitos de Siringe e Eco trarão à tona na narrativa a sexualidade agressiva de Pã e explicarão a origem de dois elementos cruciais em sua manifestação durante o ataque de pânico dos soldados. ${ }^{49}$

Fica claro, nos mitos narrado por Lâmon e por Dáfnis, que a mesma divindade capaz de salvar pode também destruir em razão do seu desejo sexual e de sua raiva

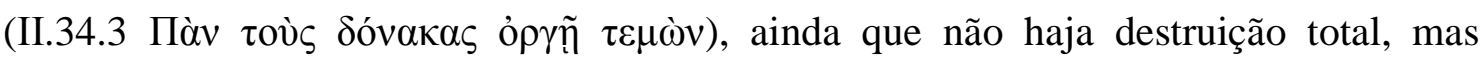
metamorfose da sua vítima. Assim, os vários aspectos de Pã - sua atuação na guerra, sua agressividade, seu desejo sexual, a infelicidade no amor, a música da siringe - são apresentados como indissociáveis (II.28.3):

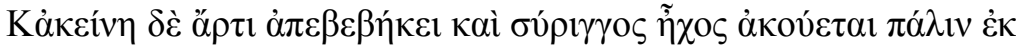

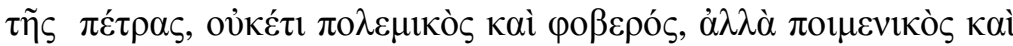

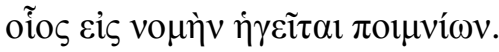

E logo que ela desembarcou, o eco da siringe foi ouvido de novo vindo das pedras, não mais marcial e amedrontador, mas pastoral, como se conduzisse os rebanhos ao pasto.

\footnotetext{
${ }^{49}$ Polieno (1.2, autor macedônio do século II d.C.) relata a invenção de um estratagema por Pã durante a campanha de Dionísio: o exército deveria gritar o mais alto possível durante a noite, para que o som ecoasse e fizesse parecer ao inimigo que seu tamanho era bem maior do que de fato era. Assustados, os inimigos fugiram. "Para honrar esse estratagema de Pã, cantamos sobre a afeição de Eco por Pã, e os

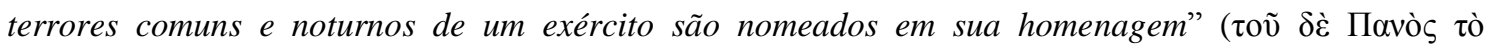

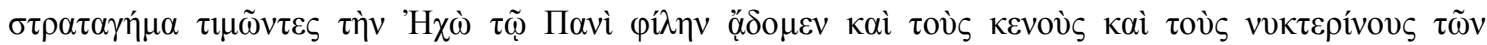

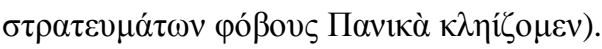


Nesse sentido, o ponto alto dos festejos após a libertação de Cloé, quando se narra o mito de Siringe e os dois pastores imitam a história por meio da dança, é a passagem da siringe de Filetas a Dáfnis (II.37). Como homem de maior autoridade no campo, seu gesto é simbólico em um processo por meio do qual o pastor se tornará um homem adulto, em posse e em controle da violência masculina representada por Pã: "toda a cena é, na verdade, construída ao redor da transmissão da siringe como símbolo do poder e da dominação masculinas" (Lalanne, 2006, p.199). ${ }^{50}$

O conflito com os jovens metimnenses introduz no romance, a partir do momento em que eles perdem o barco, um tema também observável nos mitos de Eco e Siringe. Morgan (2004, p. 216) observa que a raiva é um elemento dos mitos embutidos (cf.II.24.3 e III.23.3), ${ }^{51}$ mas não do enredo principal, até o momento da birra de Cloé em III.34.1. O crítico refere-se à passagem em que ela tenta impedir que Dáfnis apanhe uma maçã que não fora colhida por estar num galho muito alto e fica furiosa porque é

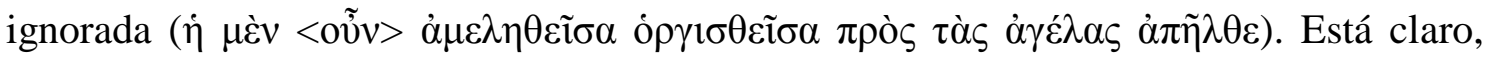
porém, que o que move os metimnenses é a raiva quando atacam Dáfnis por considerálo culpado pela perda do barco (II.14.3) por não tomar conta direito das cabras que acabam por comer o vime que prendia a embarcação à costa, e ele corre o risco de ser terrivelmente espancado. Parte, então, dos camponeses a iniciativa de realizar um julgamento. Quando Filetas decide favoravelmente ao pastor, os metimnenses

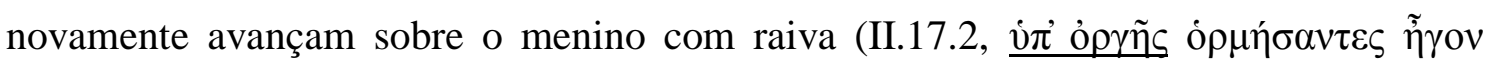

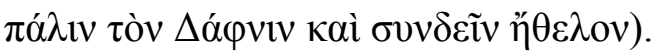

Expulsos pelos camponeses, os jovens então manipulam os fatos para convencer seus concidadãos da necessidade de uma guerra, caracterizada como "vingança"

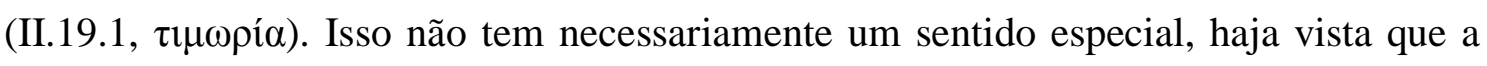
vingança era considerada pelos gregos um motivo legítimo para a guerra, ${ }^{52}$ mas Longo opta por trabalhar o tema como uma questão pessoal dos personagens envolvidos. Na sequência, o comportamento dos metimnenses continua a ser reprovável - eles pilham o campo, como os piratas haviam feito pouco antes. A aproximação entre um grupo e outro é inevitável, e Dáfnis ainda os compara a lobos, o animal que identifica outros

\footnotetext{
${ }^{50}$ Lalanne faz uma boa análise da cena (op. cit, p. 198-204).

${ }^{51}$ A raiva está ausente no primeiro mito embutido, mas apenas porque a resposta de Phátta à perda de seus animais é resignação, tristeza e abandono do mundo humano. De modo semelhante, a de Cloé, quando sente raiva, é apenas dar as costas a Dáfnis e se dirigir aos seus animais (III.34.1).

${ }^{52}$ Cf. Lendon (2009).
} 
personagens-predadores ao longo da história. ${ }^{53}$ Longo demonstra, portanto, como homens livres, ricos e nobres podem se tornar piratas se não souberem controlar seu impulso violento.

De forma menos explícita, Longo está lidando com uma questão que em Cáriton era central: o controle das emoções, especialmente da raiva (ỏ $\rho \gamma \eta$ ) masculina. A escolha do autor de explorar uma relação intertextual com Tucídides no episódio da guerra pode também ser reavaliada pelo fato de que, após a vitória dos atenienses sobre os mitilenos, o historiador relata que a primeira decisão da cidade, de matar todos os homens de Mitilene e escravizar crianças e mulheres, é tomada por causa da raiva (III.36.2, vi ì

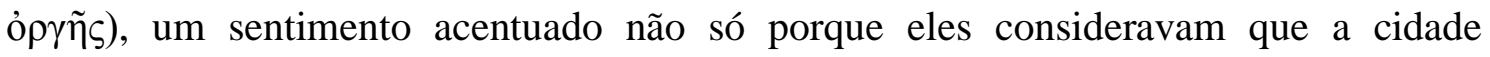
revoltosa recebia um tratamento mais brando de sua parte, mas principalmente porque a esquadra espartana havia lhes prestado ajuda. ${ }^{54}$ No dia seguinte, porém, os atenienses consideram necessário discutir novamente a decisão. $\mathrm{O}$ discurso de Cleão, chamado

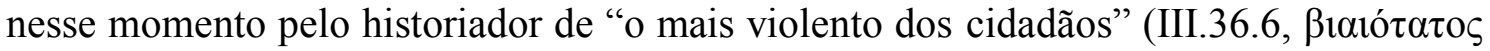
$\tau \tilde{\omega} v \pi \mathrm{o} \lambda \iota \tilde{\omega} v)$, argumenta a favor da manutenção da punição imposta à cidade de Mitilene, mas Diodoto na sequência toma a palavra e logo de início afirma que existem dois fatores principais que impedem a tomada de uma boa decisão, a pressa e a raiva (III.42.1, vo discurso, porém, não pede clemência ou uma atitude mais justa, ${ }^{55}$ mas é centrado na avaliação do que é de maior interesse a Atenas.

Diodoto considera que a punição de todas as pessoas de Mitilene em vez de apenas dos responsáveis pela revolta poderia significar, no futuro, uma maior e mais decidida adesão à insurreições. Além disso, uma cidade destruída não seria de interesse de Atenas, pois não traria nenhum ganho material. Como se pode observar, no romance de Longo o fato de que a decisão de Mitilene de não revidar o ataque de Metimna e de aceitar a proposta de paz é considerada "mais vantajosa" (ou "mais barata", como

\footnotetext{
53 II. 22.2, Dáfnis diz que nenhum lobo nunca lhe tomou uma cabra, mas agora os metimnenses haviam levado todo o rebanho. Cf. Epstein (1995) sobre personagens identificados com lobos em Dáfnis e Cloé.

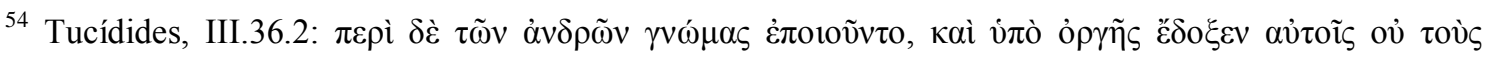

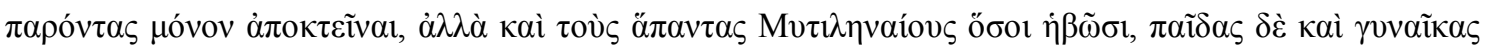

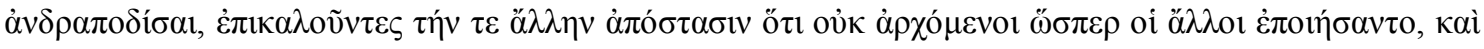

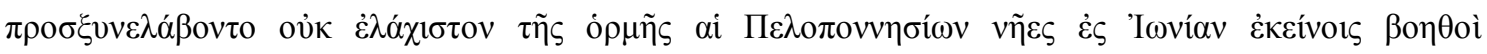

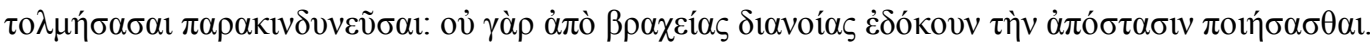

${ }^{55}$ Ver, porém, Orwin (1984) e Heath (1990).
} 


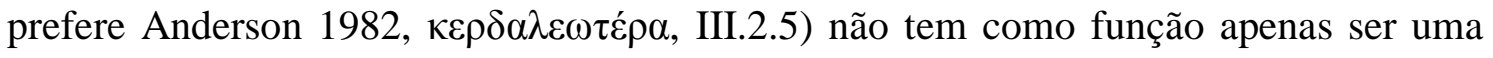
recusa à guerra na narrativa, mas alude a um debate em Tucídides centrado na oposição entre raiva e racionalidade. ${ }^{56}$ Harris $(2004$, p.179) considera que Tucídides faz uma crítica severa da orgé nesse debate, observando que no historiador "há uma insistência regular no conflito entre orgé e racionalidade". A relação entre descontrole da raiva e intenso desejo erótico também é observada na narrativa de Longo. Se a ỏpүí é a causa da morte aparente de Calírroe, o que dá início a todas as desventuras do romance de Cáriton, o desejo excessivo e a raiva de Pã são causas da destruição das suas vítimas femininas. Apenas porque o deus age no plano divino, suas vítimas acabam se metamorfoseando e permanecendo de alguma forma vivas.

O mesmo não acontece no plano humano. Cloé já havia, no livro I, sofrido o ataque de Dórcon, mas o de Lâmpis no livro IV não é uma mera repetição do motivo da ameaça de agressão sexual, porque ocorre quando Dáfnis já aprendeu o que isso significa e, conhecendo suas consequências, tem outra reação: "Mas agora Lâmpis partiu tendo-a raptado, e quando vier a noite, vai se deitar com ela" (IV.28.3, võv $\delta \dot{\varepsilon}$

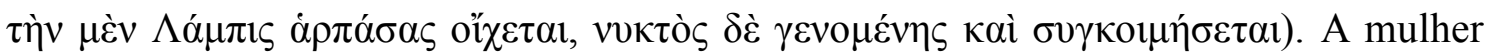
violada por outro é destruída: Cloé não poderia mais se tornar sua esposa. A preocupação de Dáfnis com a violência do ato sexual é a única coisa que havia impedido que eles o praticassem, contra as normas sociais, antes do casamento. Ao receber de Licénion finalmente a lição prática de como fazer sexo, ele só deixa de se apressar para fazer o mesmo com Cloé porque a mulher o alerta que ela gritará e sangrará muito por ainda ser virgem. Em razão disso, Dáfnis se torna deliberadamente menos caloroso nos seus carinhos. Aqui concordo com Goldhill (1995, p.39) que "o homem que tem receio de penetrar a mulher amada por causa das suas sensações físicas é uma figura cômica da imaginação grega patriarcal normativa tanto quanto o kinaidos, ou o parasita de apetites incontroláveis". A ingenuidade de Dáfnis, que o incapacita a perceber a agressão de Dórcon e o discurso eufemístico de Filetas, também o impede de compreender o que lhe diz Licénion. Porém, embora a atitude do pastor possa ter um quê de ridículo, ela não se limita, assim como muitos outros eventos do romance, apenas ao seu aspecto cômico. Estar no controle do seu desejo o distingue de personagens caracterizados de forma ambígua por cederem aos seus instintos, Dórcon, Licénion e Gnathon.

\footnotetext{
${ }^{56}$ Cf. II.11.4, 21.3; III.42.1; VI.57.3, 59.
} 
Como a sexualidade, a guerra é parte de uma construção social regrada em que os instintos naturais não devem se manifestar livremente. Ela é uma espécie de violência organizada. Nesse sentido, o narrador ressalta o comportamento ignóbil dos habitantes de Metimna desde o início, quando eles decidem começar o conflito sem anunciá-lo e, por outro lado, representa positivamente os habitantes de Mitilene. Não é sem motivo que a princípio o narrador diz que os jovens navegavam sem "fazer nenhum mal e tendo

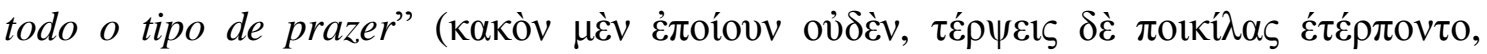
II.12.3). Isso enfatiza sua transformação em lobos ou bandidos por causa da sua raiva. Por outro lado, o comportamento de Hípaso, o general dos mitilenos, é destacado como nobre, na sua recusa justamente de agir como pirata (III.2.1) e de poupar o campo de uma violência que deve dizer respeito apenas à esfera urbana, à qual pertencem os jovens metimnenses:

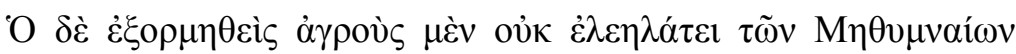

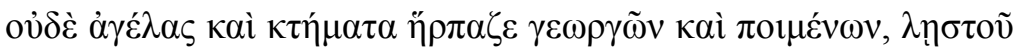

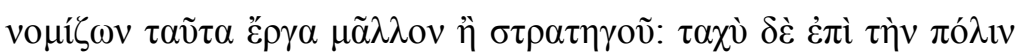
$\alpha$

Enviado à guerra, ele não pilhou os campos de Metimna nem tomou animais e bens dos camponeses e dos pastores, considerando essa atitude mais de um bandido do que de um general; mas rapidamente avançou sobre a própria cidade.

De fato, uma lição sobre esse tipo de violência só é possível pela interação com a cidade, à qual Dáfnis, afinal, pertence por causa de sua linhagem, o que coloca o episódio em paralelo com as lições de Licénion (uma mulher da cidade) e de Gnathon, o parasita que chega à fazenda junto com a comitiva de Dionisófanes. Parte dos críticos considerou Gnathon um personagem cômico inserido na oposição temática campocidade na qual a homossexualidade é apresentada como algo vicioso e não natural que, portanto, não teria lugar no cenário bucólico ideal em que se passam os eventos de Dáfnis e Cloé. Creio, porém, que se trata da última etapa da educação social-sexual de Dáfnis, que precisa terminar a história sabendo da diversidade dos prazeres sexuais. É evidente que não existe oposição completa entre campo e cidade no romance, porque os dois protagonistas fazem parte de ambos. Apesar de sua escolha em permanecer no 
campo depois do casamento, o narrador não nos deixa esquecer que eles devem se portar como aristocratas citadinos. Afinal, a mãe adotiva de Cloé pensa em arranjar logo um casamento para ela por temer que acabasse perdendo a virgindade em troca de maçãs ou rosas (III.25.3) e, ao menos na primeira parte do romance, nenhum dos dois protagonistas se preocupa com castidade, mas o pai de Dáfnis chama discretamente o recém-encontrado filho de lado para saber se Cloé ainda era virgem. E, no seu final feliz, o casal tira a estátua de Pã de debaixo do pinheiro e constrói um templo para "Pã soldado". De todos os aspectos do deus, o que é celebrado no fim do romance é o único que diz respeito a uma esfera de atuação urbana.

O tema da guerra também está presente nas duas representações pictóricas do romance: se no quadro da caverna das Ninfas, mencionado no proêmio, sua presença apenas o anuncia como tema a ser desenvolvido, a representação de Dioniso em batalha na Índia nos jardins de Dionisófanes, por outro lado, assinala a importância do tema mesmo no que diz respeito a um deus associado sobretudo à fertilidade do campo. Postas lado a lado estão imagens de Sêmele dando à luz, Ariadne dormindo, Licurgo acorrentado, Penteu sendo destroçado, a transformação dos piratas tirrenos, sátiros, mênades e Pã tocando sua flauta sentado sobre um rochedo. Ele também teria participado como general na campanha militar de Dioniso na Índia. ${ }^{57}$ Com efeito, quando as Musas aparecem em sonho para Dáfnis, além de observar que ele deveria honrar Pã do modo apropriado, elas lhe dizem que o deus havia deixado o campo diversas vezes para participar da guerra (II.23.4). Essa fala alude a um evento conhecido da história ateniense, relatado por Heródoto (VI.105): trata-se da epifania de Pã ao mensageiro enviado por Atenas a Esparta, Fidípides, para pedir ajuda contra os persas, e que relatou ter tido um encontro com o deus próximo do Monte Partênio. Pã o teria chamado pelo nome e pedido que perguntasse aos atenienses por que eles o negligenciavam totalmente, se sua disposição era favorável a eles e ele os havia ajudado antes e voltaria a ajudar no futuro. Alguns dias depois, ocorreu a batalha de Maratona. Os atenienses acreditaram no relato do seu mensageiro, construíram um templo para Pã sob a Acrópole e instituíram ao deus sacrifícios anuais e uma corrida com tochas. Esse é

\footnotetext{
${ }^{57}$ Referências a essa atuação: Polyaen.12, Luc. Dion.4, Diod.Sic. 1.18. A versão mais elaborada da história, que Borgeaud sugere ter se originado na época da expedição de Alexandre à Índia, está na Dionysiaca de Nonnos. Cf. Borgeaud (1988, p.100ss) e nota 49 deste capítulo.
} 
o primeiro envolvimento conhecido de Pã em conflitos bélicos não míticos ${ }^{58}$ e está claro que de modo geral os eventos em Longo reproduzem o que se passa em Atenas: Dáfnis é alertado para não mais negligenciar Pã, recebe sua ajuda em guerra e passa a honrá-lo.

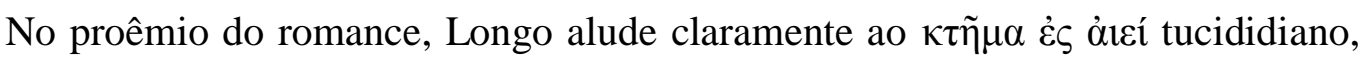
sugerindo uma utilidade e perenidade da narrativa que virá na sequência, mas sua ironia é clara na importância que ele confere ao prazer por ela provocado nos leitores, de modo que sua postura, como observou Hunter (1983, p.49), é mais próxima, na verdade, de Heródoto do que de Tucídides. A alusão ao historiador ateniense é feita, portanto, em parte para rejeitá-la. Do mesmo modo, no episódio bélico, a reminiscência da revolta de Mitilene narrada no livro III, o estilo e a fraseologia tucididiana que irrompem no texto, estão deslocados no romance porque - e aqui concordo com Trzaskoma (2005) - são rejeitados pelo narrador. Isso não equivale, contudo, a uma recusa do tema da guerra. Ao contrário, Longo encontra a maneira apropriada de inseri-la num romance pastoral, centrando a ação em Pã, o único que pode ser tanto soldado quanto pastor, tanto conduzir quanto destruir. Assim, inserido na oposição temática campo vs. cidade, contando com a presença fundamental do deus Pã e apresentando um modelo de masculinidade no uso da violência que não se relaciona à agressividade erótica, os episódios da invasão dos piratas e da guerra entre Metimna e Mitilene também dizem respeito ao projeto de Longo de representar uma paideia de Dáfnis e Cloé, que iniciam a narrativa inocentes e infantis em suas brincadeiras pastoris, e terminam em sua posição social devida, consumando seu casamento e adentrando a vida adulta.

\footnotetext{
${ }^{58}$ Cf. Borgeaud (1988, p.94ss) sobre Pã e a batalha de Maratona e (idem, p.133ss) sobre o culto do deus em Atenas.
} 


\title{
As Etiópicas: Um novo Aquiles
}

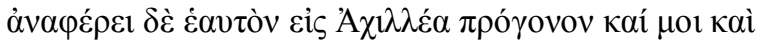

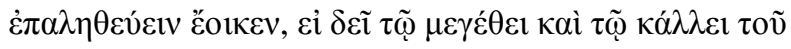

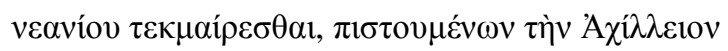

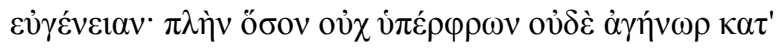

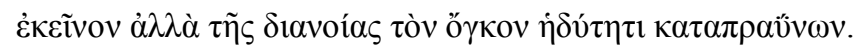 \\ O jovem traça sua linhagem a Aquiles e parece-me que isso \\ pode bem ser verdade, a julgar pela sua estatura e beleza, \\ fiéis à nobreza de Aquiles; só que [Teágenes] não é nem \\ arrogante nem altivo como ele, o espírito orgulhoso é \\ suavizado pela doçura.
}

Heliodoro, IV.5.5

O romance de Heliodoro é o mais tardio do seleto grupo que chegou até nós. O primeiro testemunho conhecido sobre o autor é de Sócrates, autor do século V d.C., o que nos fornece o terminus ante quem da obra, mas o debate sobre a datação centra-se sobretudo na relação entre o romance e duas orações do Imperador Juliano (I e III), em que se relata o terceiro cerco à cidade de Nisibis pelo rei persa Sapor II em 350 d.C., que possui muitas semelhanças com a descrição do cerco de Siene no livro IX das Etiópicas. A datação é uma questão bastante controversa e, ainda que haja diversos indícios que apontam para a segunda metade do século IV d.C. (mais especificamente o período entre 350-375 d.C.), não se pode deixar de considerar a possibilidade da narrativa ter sido produzida ainda no século III d.C. ${ }^{2}$ É mais provável que Heliodoro tenha sido influenciado por Juliano, mas o inverso também pode ter acontecido, ou ainda os dois podem ter tido uma fonte comum.

\footnotetext{
${ }^{1}$ A edição utilizada do texto de Heliodoro é a de Rattenbury e Lumb para a coleção Budé (tomo I, 2011; tomo II e tomo III, 2003; primeira edição de 1935).

${ }^{2}$ Cf. Bowie (2002) e Morgan (1996).
} 
Rohde supôs que se tratava, porém, do primeiro dos romances, organizando o corpus cronologicamente em proporção inversa à complexidade narrativa apresentada por cada uma das obras. De fato, podemos observar em Heliodoro não só um uso mais sistemático e sofisticado da tradição literária, como uma estrutura narrativa bastante complexa, que dá a conhecer gradativamente os fatos ao leitor a partir de diferentes pontos de vista, além de apresentar acentuados aspectos filosóficos e religiosos que conferem à obra um tom mais grave que dos demais romances. Trata-se também de uma obra extensa, que ocupa três volumes das edições Budé. Não é difícil entender por que o autor era considerado, no Renascimento, o terceiro poeta épico ao lado de Homero e Virgílio. ${ }^{3}$ É curioso observar, no entanto, que em diversos aspectos Heliodoro é mais próximo de Cáriton de Afrodísias do que de Longo e Aquiles Tácio, dois autores em que é possível discernir ironia no tratamento das convenções do gênero e uma menor idealização na caracterização do par romântico. Há novamente uma forte aproximação com a historiografia, como vemos acontecer nos primeiros romances, mas enquanto em Cáriton a ilusão de que são narrados fatos históricos é construída principalmente por meio da ambientação e da menção a figuras históricas conhecidas, em Heliodoro ela ocorre sobretudo por causa da adoção de diversas estratégias discursivas empregadas na historiografia (cf. Morgan, 1982).

\section{IV.1 Resumo do Enredo}

Aqui fazemos um resumo tão breve quanto possível da história de Teágenes e Caricleia em As Etiópicas, deixando de lado boa parte dos fatos que concernem a personagens secundários. A narrativa começa com uma cena de destruição e morte na boca heracleótica do Nilo, observada por um grupo de bandidos. No chão há restos de um grande banquete e nota-se um navio mercante ainda carregado. Eles observam um homem ferido gravemente e uma mulher ao seu lado, que são Teágenes e Caricleia, o par romântico protagonista do romance. Toda a cena é apresentada pela perspectiva dos bandidos e o leitor compartilha com eles a ignorância dos fatos, acompanhando-os em

\footnotetext{
${ }^{3}$ Cf. Bertoni e Fusillo (1993), Pinheiro (1996), Sandy (1996).
} 
suas conjecturas sobre aquilo que observam. ${ }^{4}$ Esses bandidos, porém, logo avistam outro grupo bem maior se aproximando e fogem sem levar nada. Os dois bandos são identificados com os boukoloi, famosos bandidos do delta do Nilo. O casal é aprisionado e deixado sob a vigilância de um ateniense que havia se tornado prisioneiro do bando há algum tempo, Cnemon. Nessa noite, Tíamis, o líder dos boukoloi, sonha com a deusa Ísis, que lhe diz que ele terá e não terá Caricleia, e que a golpeará, mas não a matará. Tíamis entende que o sonho está lhe dizendo que desposará Caricleia. Na divisão dos espólios, ele solicita-a como sua parte, acreditando que Teágenes é seu irmão.

Pouco depois, porém, os bandoleiros são atacados pelo mesmo grupo que fugira deles anteriormente e Tíamis, que havia deixado Caricleia em uma caverna, com receio do que poderia acontecer, dirige-se até lá com intenção de matá-la. Ele acaba golpeando uma mulher que falava grego e que ele presume ser Caricleia, o que configura o episódio de morte aparente do romance. Teágenes desespera-se quando descobre o cadáver, mas logo se revela que a mulher, na verdade, era Tisbe, uma escrava que teve papel importante no exílio do ateniense Cnemon. Ele havia contado sua história pouco antes: vítima de uma conspiração de sua madrasta, de quem havia rejeitado as tentativas de sedução, fora julgado culpado de tentativa de assassinato do próprio pai.

Tíamis, por sua vez, é capturado vivo pelo bando, que havia sido enviado por seu irmão Petosíris. Ele já havia revelado não ser um simples bandido, mas herdeiro por direito do posto de sacerdote de Mênfis, usurpado por seu irmão. O leitor também descobre adiante que ele é filho de Calasíris, personagem que tem papel fundamental na narrativa. Não apenas pela sua intervenção nas vidas de Caricleia e Teágenes, mas também como narrador de tudo o que havia acontecido antes do momento em que o romance tem início, quando conta para Cnemon sua história e a do casal sob sua proteção. É quando o leitor é informado que Caricleia havia sido criada em Delfos por Cáricles, sacerdote de Apolo, que havia recebido a criança no Egito, das mãos de um sacerdote etíope, Sisimitres. Como havia se tornado uma devota de Ártemis, Caricleia tinha intenção de se manter casta. Por isso, Cáricles pede que Calasiris use sua magia egípcia para convencer a filha a se casar, mas pouco depois chega a Delfos um grupo da

\footnotetext{
${ }^{4}$ Trata-se de uma característica notável da narrativa de Heliodoro que muitas vezes o narrador fique em segundo plano e as informações passem a ser conhecidas dos leitores apenas quando são transmitidas entre os personagens.
} 
Tessália, liderado por Teágenes, descendente de Aquiles, para realizar um rito em honra a Neoptólemo. No momento em que Teágenes iria dar início à cerimônia, a pítia profere o seguinte oráculo (II.35.5):

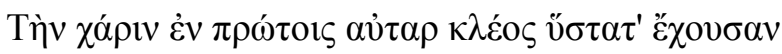

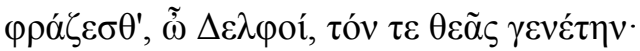

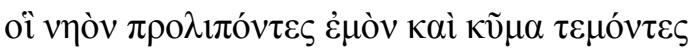

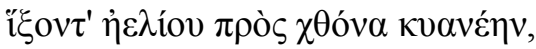

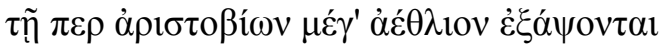

$\lambda \varepsilon v \kappa o ̀ v ~ \varepsilon ̇ \pi i ̀ ~ \kappa \rho о \tau \alpha ́ \varphi \omega v ~ \sigma \tau \varepsilon ́ \mu \mu \alpha ~ \mu \varepsilon \lambda \alpha เ v o \mu \varepsilon ́ v \omega v$.

Celebrai, ó povo de Delfos, aquela que é no início graça e no fim

glória e aquele que foi gerado por uma deusa!

Partindo do meu templo e cortando os mares

Chegarão à negra terra do Sol

Onde colherão o grande prêmio pelas vidas virtuosas,

Uma coroa branca sobre negras têmporas.

O narrador nesse momento apenas registra a reação de surpresa das pessoas ao oráculo - elas não conseguem explicá-lo. Ao leitor cabe então a tarefa de reconhecer os

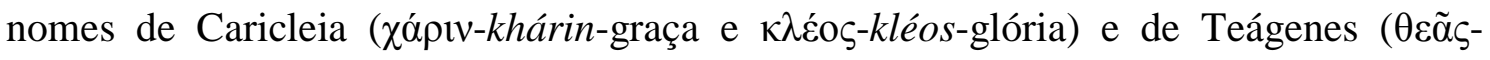

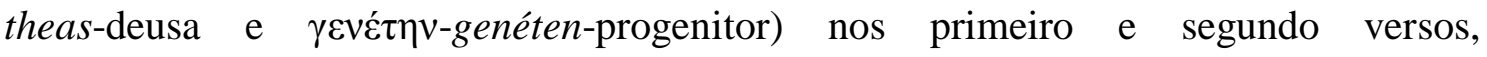
respectivamente. Durante a cerimônia, da qual deveria participar a sacerdotisa de Ártemis, o casal encontra-se pela primeira vez e a paixão é imediata e recíproca.

Apenas Calasíris, porém, percebe o amor entre os dois e arquiteta a união do casal, no que acaba resultando em um rapto de Caricleia. Ele também descobre, observando os objetos deixados com a jovem quando ela foi entregue a Cáricles, que ela é filha de Persina, rainha da Etiópia, e que foi abandonada porque nasceu branca e porque a rainha temia sofrer uma suspeita de adultério (o que é posteriormente justificado pelo fato de Persina observar um quadro de Andrômeda no momento da concepção da filha). Calasíris revela a Caricleia sua verdadeira origem e diz que sua mãe o havia enviado a Delfos para encontrá-la. Os três embarcam em um navio mercante fenício e é então que as aventuras do casal têm início longe da Grécia.

A cena de destruição que inicia a narrativa só é explicada no livro V: logo que partem da Grécia, a beleza de Caricleia começa a atrair pretendentes, entre eles 
Traquino, o líder de um grupo de piratas que conseguem alcançar e atacar o barco fenício no momento em que estava deixando Creta. Uma tempestade dirige o navio dos piratas até o Nilo. Lá, Calasíris diz ao segundo na hierarquia do bando, Peloro, que Caricleia estava apaixonada por ele. É a disputa por ela que provoca a carnificina durante aquela que deveria ser a festa de casamento da heroína com Traquino e que é o cenário do início da narrativa. Em seguida, eles separam-se de Calasíris quando são levados pelo bando de Tíamis. Aqui se encerra a narrativa do velho egípcio.

Depois que Tíamis é capturado, o casal fica sozinho no acampamento dos boukoloi e é surpreendido pela guarda persa. Tomados como prisioneiros, Caricleia é levada pelo mercador Nausicles, que permitirá o seu reencontro com Cnemon e Calasíris, nesse momento hospedados em sua casa. Já Teágenes é primeiro levado como prisioneiro por Mitranes, chefe da guarda persa e, depois, capturado novamente por Tíamis. A essa altura, o egípcio já estava livre e de novo no comando de um grupo de homens da cidade de Bessa. Enquanto Cnemon decide permanecer na casa de Nausicles e casar-se com sua filha, Caricleia e Calasíris partem em busca de Teágenes. Chegando a Mênfis, eles observam a cidade cercada pelos boukoloi.

No início do livro VII, ocorre a resolução do conflito de Calasíris e seus filhos; ele impede um duelo entre os dois, assume temporariamente o posto de sacerdote e morre pouco depois, deixando o lugar para Tíamis. Aí tem início em Mênfis a perseguição de Arsace, esposa do sátrapa do Egito, a Teágenes, a quem ela deseja loucamente, ao passo que Aquemenes, um de seus escravos, deseja desposar Caricleia. Vendo frustrado seu desejo, Arsace manda prendê-lo e torturá-lo. Sua serva Cibele sugere então matar Caricleia envenenada, mas ela própria acaba tomando o veneno por engano. Antes de morrer, porém, ela acusa Caricleia, que decide confessar o crime, já que ela e Teágenes não viam saída para sua situação e tinham se decidido por um pacto suicida. Condenada e levada à pira, o fogo não consegue atingi-la porque ela usava no dedo uma pedra mágica chamada pantarbe que a protegia. Diante dessa cena, o povo a considera inocente.

Aquemenes procura então o sátrapa Oroondates, relatando os fatos provocados pela luxúria da sua esposa, e este decide ordenar que o eunuco Bagoas traga tanto Teágenes quanto Caricleia à sua presença. No caminho até a Siene, onde o sátrapa se encontrava sitiado, porém, o eunuco e o casal são emboscados pelos etíopes, feitos prisioneiros e levados até o rei Hidaspes, pai da heroína, mas ela decide não revelar sua identidade de imediato. A lei da Etiópia, porém, estabelecia que os primeiros 
prisioneiros de guerra fossem sacrificados e é desse destino que o par romântico terá de escapar até o fim da história.

O livro IX é quase inteiramente um relato de guerra. Hidaspes, depois de ver frustrada sua primeira tentativa de tomar Siene, constrói um fosso e um dique ao redor da cidade. O fosso é então enchido com água do Nilo, o que provoca terror nos habitantes da cidade pela possibilidade de ela vir a ser destruída pelas águas. Oroondates é assim forçado a se render, mas pouco depois foge com seu exército e chega a Elefantina, onde a maior parte da armada persa se encontrava. Ocorre então uma batalha entre as forças persa e etíope, vencida pela última.

Os acontecimentos do livro $\mathrm{X}$ se passam quase totalmente em Méroe, na Etiópia. Tanto Teágenes quanto Caricleia passam por uma prova que atesta a castidade de ambos - outra condição necessária para que fossem vítimas apropriadas do sacrifício ao Sol e à Lua. Ela então revela sua identidade. O povo pede que Caricleia seja poupada do sacrifício, mas Teágenes continua em perigo. É nesse momento que Cáricles surge em cena, em busca da sua filha adotiva raptada em Delfos. Depois que toda a situação é esclarecida, Persina decide abolir de uma vez por todas o sacrifício humano na Etiópia, atendendo à observação do sacerdote Sisimitres de que o que havia se passado era um indício de que os deuses não viam o ritual com bons olhos. Teágenes e Caricleia casamse finalmente e são nomeados sacerdotes do Sol e da Lua. Cáricles lembra-se então do oráculo em Delfos e conclui que ele havia se cumprido.

\section{IV.2 As Etiópicas: uma odisseia filosófica?}

Não há proêmio em As Etiópicas e, como se pode notar pela paráfrase, o romance tem início in medias res. O leitor precisa avançar até metade da história, no final do livro $\mathrm{V}$, para descobrir o que ocasionou a primeira cena. Trata-se de uma estratégia ímpar entre os romancistas, que gera suspense e expectativa no leitor (mesmo que familiarizado com as convenções do romance) de descobrir não o que acontecerá aos personagens principais, mas o que aconteceu a eles antes da narrativa começar. É 
uma primeira amostra da extrema complexidade narrativa da obra. ${ }^{5}$ Essa também é uma característica que associa As Etiópicas ao gênero épico, cuja grandiosidade é sentida no texto todo o tempo. Ela se faz presente não só na estrutura geral do romance, mas também por meio de frequentes alusões, e em ambos os casos a Odisseia é o intertexto principal. Aliás, como observa Sandy (1982, p.85), “os primeiros versos da Odisseia contêm as sementes do enredo básico de As Etiópicas: o deus sol Hélio, Etiópia, viagens e a busca pelo retorno".

Em Heliodoro, é Calasíris quem assume a função de segundo narrador e ele é explicitamente associado a Odisseu, quando relata um sonho que teve com o herói, (V.22) e a Homero, quando fala sobre a origem egípcia do poeta (III.14), também como ele, um exilado em terras gregas. Além disso, esse é o único dos romances em que a viagem não tem uma trajetória circular, em que os personagens são afastados da sociedade grega para retornar no fim: Caricleia e Teágenes deixam Delfos ${ }^{6}$ em direção à Etiópia, onde ela deve assumir sua posição como membro da família real. E, mesmo assim, é na história de Caricleia, mais do que de qualquer personagem dos romances de amor, que a ideia do nóstos é percebida: "Homero é, dessa forma, um paradigma não apenas poético, mas existencial; é a ele como personagem que remonta o tema romanesco do exílio, associado não apenas a Calasíris, mas também a Caricleia" (Fusillo, 1991, p.27). ${ }^{7}$

As referências à tragédia também permeiam toda a obra, não só por causa das alusões textuais, mas pela presença de vocabulário técnico, ${ }^{8}$ em geral utilizado quando os personagens comparam as situações que estão vivendo a situações dramáticas, e vários dos eventos são apresentados como uma espécie de espetáculo, observados por uma audiência interna. ${ }^{9}$ Isso gera diversos efeitos na leitura, como observou Morgan

\footnotetext{
5 Sobre as estruturas narrativas de As Etiópicas, cf. Winkler (1999, original de 1982), Pinheiro (1991), Morgan (1999) e Berry (2000).

${ }^{6}$ Sobre a representação de Delfos em Heliodoro, cf. Rougemont (1992).

${ }^{7}$ Cf. Whitmarsh (2012, p.114s): "The exile theme also has a wider relevance: all of Heliodorus' major characters suffer some kind of expatriation. Charicleia and Theagenes, then, can be read as the Odyssey Homer would have written had he lived his days on the fertile banks of the Nile".

${ }^{8}$ Há um léxico detalhado dos termos feito por Halden (1894). Ainda é possível observar diversos elementos de obras específicas presentes na trama; um exemplo é a história de Cnemon, para a qual Hipólito, de Eurípides, é uma fonte evidente. Para uma análise da presença de Eurípides no romance, sobretudo de Íon nos livros VII e VIII, cf. Pletcher, 1998.

${ }^{9}$ Cf. Bartsch (1989) e Morgan (1992).
} 
(1996): há um movimento da diégese para a mímesis, do que resulta que, com frequência, o leitor tem em mãos a descrição visual de um evento focalizado a partir de algum personagem, o que enfatiza a força emocional da narrativa.

É notável também que a estrutura do romance de Heliodoro é menos episódica do que a dos demais romances, havendo uma sequência mais bem amarrada nos eventos. Personagens secundários têm funções em mais de uma seção da narrativa, de modo que quando novos personagens são introduzidos, eles carregam consigo experiências que os relacionam a eventos já narrados. ${ }^{10}$ Elementos recorrentes dos romances também são mais bem inseridos na trama: Tíamis, por exemplo, que ocupa os papéis convencionais tanto do bandido quanto do amigo de Teágenes, além do de pretendente da heroína, é personagem central de uma trama própria que de alguma forma se relaciona com a dos protagonistas, que consideram Calasíris uma figura paterna.

Das diversas características que marcam o romance de Heliodoro como superior em ambição e complexidade, porém, a mais controversa é o tom religioso reconhecível na narrativa, que é às vezes relacionado à biografia do autor. Heliodoro conclui o seu romance da seguinte forma (X.41.3): “Assim se encerram As Etiópicas, a história de Teágenes e de Caricleia, composta por um fenício da cidade de Emesa, um dos descendentes do Sol, Heliodoro, filho de Teodósio". ${ }^{11}$ Emesa era um centro reconhecido de culto ao deus Sol e o autor parece indicar na sua assinatura que tem algum envolvimento com ele. Isso levou a análises do romance que buscaram ressaltar elementos do culto presentes no enredo, entendendo o Sol como a divindade que controla as ações dos personagens - ele também é identificado com Apolo (em X.36.3). ${ }^{12}$ Essa linha de interpretação do romance parece não ter deixado seguidores, mas a presença divina na trama é entendida por alguns críticos como religiosa em um

\footnotetext{
${ }^{10}$ Um exemplo é o comerciante Nausicles. Quando surge no romance, como anfitrião de Calasíris, ele já havia sido amante de Tisbe em Atenas, a cortesã envolvida na trama contra Cnemon, e é ele quem possibilita o reencontro entre Caricleia, que resgata do campo dos boukoloi, e o velho egípcio, além de se tornar sogro de Cnemon, pouco antes dos dois personagens saírem definitivamente de cena.

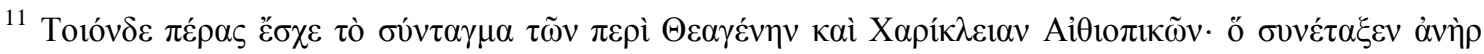

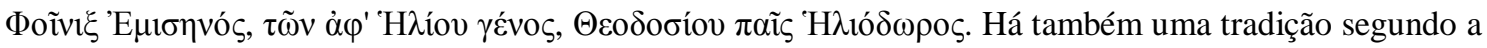
qual Heliodoro teria sido um bispo cristão, cf. Sandy (1982, p.1-8).

12 Essa abordagem, desenvolvida por Altheim (1948) e Weinreich (1950) difere daquela de Kerényi (1927) e Merkelbach (1962), segundo a qual os romances teriam elementos dos mistérios só reconhecíveis aos iniciados.
} 
sentido mais geral. Tal é o caso de Dowden (1996), que advoga que o romance não só representa os eventos narrados como parte de um mundo divinamente ordenado, mas que também foi composto tendo em vista a exposição da filosofia platônica. ${ }^{13}$ Essa postura, contudo, não é consenso: Morgan no mesmo ano (1996) defendeu que os deuses em As Etiópicas não passam de um recurso narrativo, "sem nenhuma referência para além dos limites de sua própria ficção". ${ }^{14}$

É bizantino - ou ainda mais antigo - o debate a respeito de quão séria é a intenção de Heliodoro de propagar uma visão filosófica por meio de sua narrativa. Uma análise conhecida do romance é feita por um obscuro Filipe, o Filósofo, sobre o qual não há como saber sequer em que século viveu - as hipóteses já feitas são os séculos $\mathrm{V}$, VI e XII. ${ }^{15}$ Ao conversar com um grupo de jovens que zombavam de Caricleia, Filipe introduz sua interpretação comparando o livro à infusão de Circe, que pode tanto transformar os leitores em porcos ou, se entendido filosoficamente, à maneira de

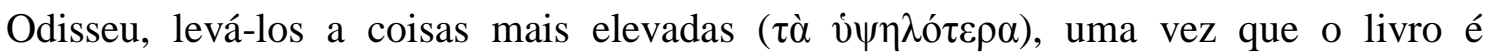

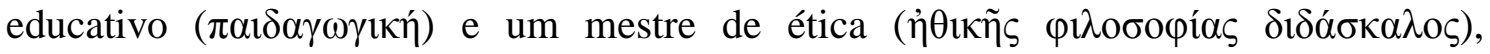
misturando à água da história o vinho da contemplação $(\theta \varepsilon \omega \rho i ́ \alpha){ }^{16}$

Essa leitura em camadas é algo comum na Antiguidade Tardia e no período bizantino, ${ }^{17}$ mas algo importante a se observar com relação a Heliodoro é que a interpretação se faz presente em diversos momentos da sua narrativa - o oráculo em Delfos, por exemplo, é uma peça central que nenhum cidadão consegue desvendar, e

13 Sandy (1982), por sua vez, argumenta que o viés platônico na obra não constitui uma doutrina filosófica coerente, mas é importante na caracterização de Calasíris.

14 Morgan anos antes (1989b) tinha demonstrado que Heliodoro faz uma distinção entre dois tipos de amor no romance: aquele de Teágenes e Caricleia e o de Cnemon e Tisbe. Dowden (1996) define-os como dois tipos platônicos, celestial e pandêmico.

${ }^{15} \mathrm{O}$ texto grego está publicado entre os testimonia de Heliodoro na edição de Colonna (1938, p.365-370). Há uma tradução para o inglês em Lamberton (1989, p.306-311).

${ }^{16} \mathrm{O}$ primeiro tipo de interpretação que Filipe oferece aos seus jovens interlocutores é moral: além dos bons terem final feliz e dos maus serem punidos, alguns personagens são exemplos de boa conduta. Em seguida, Filipe faz uma interpretação alegórica do romance, em que é notável sua influência neoplatônica.

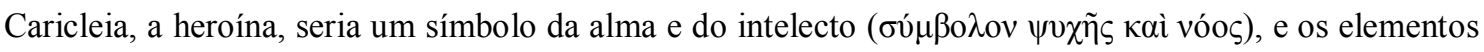
do seu nome resultariam nos números 777 , três vezes um número sagrado: 700 representando o reverente e o perfeito, 70, a alma, e 7, o corpo. A narrativa é entendida alegoricamente então como uma ascensão da alma (Caricleia) ao mundo intelectual, despertada pela visão de Teágenes.

17 Para uma história da recepção de Heliodoro pelos bizantinos, cf. Agapitos (1998) e Beaton (1996). Sobre Filipe, o Filósofo, cf. Hunter (2005). 
interpretações de sonhos abundam. ${ }^{18}$ Os diferentes processos interpretativos na economia interna do romance, ${ }^{19}$ desse modo, de fato se relacionam com as várias análises solicitadas ao leitor ao longo de sua leitura e Heliodoro parece indicar que existe a "interpretação certa" não só para sonhos ou oráculos, mas também para os acontecimentos da vida dos personagens. Seria, então, intenção do romancista apresentar conteúdo "sério", filosófico, que estaria mesclado aos efeitos prazerosos da leitura da ficção? A análise de Filipe tem em vista um aprendizado moral, mas uma utilidade muito diferente para o romance é dada pelo médico Teodoro Prisciano, que escrevendo em cerca de 400 d.C. recomendou a leitura de romances eróticos para a cura da impotência masculina. Já se sugeriu que um dos autores mencionados, Herodiano, seja identificado com Heliodoro. ${ }^{20}$

Que elementos platônicos ou pitagóricos estão inseridos na narrativa de Heliodoro parece algo irrefutável. No entanto, é característica essencial do romance ser uma forma aberta, que incorpora elementos e técnicas dos demais gêneros literários. A questão, portanto, é saber se o uso que o autor faz desses elementos corrobora a ideia de que Heliodoro pretendeu escrever um romance filosófico, propagando uma visão coerente dos seus preceitos. Morgan (1996), contrário a essa hipótese, observa que o mito da queda e ascensão da alma, da forma como é vista por Filipe no romance, é característico do período e que não seria implausível que um romance fosse escrito como sua alegoria. No entanto, o romance de Heliodoro não seria esse romance (1996, p.446):

O tema do retorno aplica-se somente a um dos protagonistas, deixando Teágenes como um apêndice sem significado e a queda da alma (a exposição de Caricleia quando criança) parece residir na própria entidade (a mãe) para a qual ela deve voltar.

\footnotetext{
${ }^{18}$ Em uma dessas ocasiões, Teágenes analisa um sonho profético que é, na verdade, desprovido de símbolos (VIII.11). Na prisão em Mênfis, ele havia sonhado com Calasíris, que lhe dizia que com uma

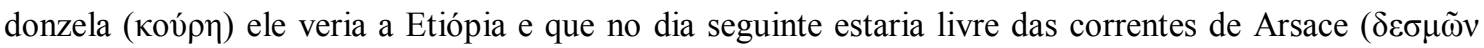

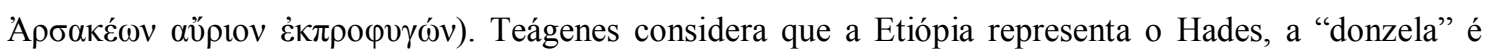
Perséfone e "estar livre" indica que sua alma deixará o corpo. Pode-se considerar que a interpretação de Teágenes aqui ajuda a criar suspense com relação à possibilidade de um final "infeliz" para o casal (cf. Morgan, 1989a).

${ }^{19}$ Cf. Winkler (1999, original de 1982) e Hunter (1998).

${ }^{20}$ Cf. Bowie (1994).
} 
De fato, um problema frequente das interpretações alegóricas já sugeridas aos romances é o fato de que elas selecionam alguns elementos que corroboram a leitura, sem dar conta da narrativa como um todo. Dowden (1996), porém, afirma que, se o romance de Heliodoro permite uma interpretação religiosa e filosófica, não deveríamos alegar que essa não era a intenção principal do autor. ${ }^{21}$ Por outro lado, Heliodoro não parece fazer uma representação o tempo todo coerente dos deuses (cf. Morgan 1996) como o crítico parece supor, e alguns de seus argumentos, que sugerem a mão divina atuando em diversos momentos da narrativa, são pouco convincentes. ${ }^{22}$

Tivesse ou não intenção de propagar uma visão religiosa e filosófica específicas por meio de seu romance, como quer Dowden, agindo como uma espécie de "guia místico", Heliodoro apresenta a história de Teágenes e de Caricleia, de fato, como uma série de eventos divinamente orquestrados. Afinal, creio que não se deve duvidar da interpretação feita pelo sacerdote etíope Sisimitres no último livro (X.39.1-3), de que o retorno da filha de Persina e Hidaspes e os demais acontecimentos em Méroe eram indício de que os deuses não aprovavam o sacrifício humano e desejavam sua abolição definitiva na Etiópia. Hunter (1998, p.58-59), contudo, influenciado pela abordagem narratológica de Winkler (1999, original de 1982), sugere que essa interpretação de Sisimitres, embora "correta", está no mesmo patamar que aquela que Tíamis faz de seu próprio sonho, do que resulta que ele pode justificar o seu desejo de desposar Caricleia, ou seja, ambos agem guiados por seus próprios interesses: "Sisimitres assim impôs a

\footnotetext{
${ }^{21}$ Um exemplo claro de que Heliodoro esperaria esse tipo de leitura de seu romance é a análise numerológica que Filipe, o Filósofo, faz do nome de Caricleia, ao afirmar que ele resulta em um perfeito 777. Dowden se pergunta se Heliodoro realmente teria tido intenção de que seus leitores percebessem que o nome da heroína totaliza esse número. A resposta é positiva porque no próprio romance o sacerdote de Siene diz que as letras que formam o nome "Nilo" totalizam 365, o número de dias do ano (IX.22.6).

${ }^{22}$ Um exemplo é sua argumentação em favor da atuação dos deuses no fato de que as chamas não conseguem atingir Caricleia quando ela está a ponto de ser executada na pira. Grande importância é dada ao fato de que ela utilizava um anel com uma pedra mágica chamada pantarbe capaz de protegê-la do fogo. A própria personagem, contudo, supõe também o auxílio dos deuses (VIII.11.8) e Dowden defende (p.277s) que é para essa segunda explicação que o autor deseja, de fato, chamar a atenção, o que nos parece pouco razoável. Outro exemplo é o fato de que ele considera que, diferentemente dos demais romances, em Heliodoro o destino dos personagens maus é subordinado à organização divina na trama. Isso parece claro no caso de Termoutis, mas não no caso dos piratas, que se entregam à violência uns contra os outros não só em razão do seu gênio bárbaro, mas graças principalmente à astúcia de Calasíris.
} 
sua própria 'probabilidade', antecedendo-a por uma bajulação desnecessária ao rei para fazê-la parecer ainda mais 'natural"'. Aqui, porém, concordo com Dowden que às vezes se tende a priorizar jogos narrativos na análise de Heliodoro em detrimento de intenções sérias que existem no romance, ainda que eu acredite que em um grau menor do que sugere o crítico (1996, p.285): "é importante que não sejamos levados pelo atual interesse em técnica literária e em romances que promovam a ambivalência, a rejeitar métodos e conteúdos de romances de outras culturas".

O reconhecimento de Caricleia e o final feliz do casal têm função para além da história de dois indivíduos: eles estão inseridos numa sequência ordenada pela vontade dos deuses e que provoca mudança positiva na vida dos etíopes, que pareciam irrepreensíveis aos olhos do leitor com exceção do fato de ainda praticarem o antigo costume de realizar sacrifício humano após vitória militar contra um inimigo estrangeiro. Disso decorre necessariamente que não é um caso fortuito que Teágenes e Caricleia cheguem à Etiópia como os primeiros prisioneiros de guerra feitos no conflito pelas minas de esmeralda e, nesse sentido, a unidade narrativa mencionada anteriormente, obtida por meio de episódios mais bem concatenados e amarrados do que costumam ser nos demais romances, deve ser entendida também como indício do propósito reservado pelos deuses ao casal.

\section{IV.3 Teágenes e Caricleia entre bandidos e piratas: a violência de Tíamis}

Antes do grande episódio bélico desenvolvido no livro IX, há diversos conflitos menores no romance a que o autor se refere como $\pi$ ó $\lambda \varepsilon \mu \rho \varsigma$, de modo que os confrontos violentos são uma parte essencial do romance. O termo é usado repetidas vezes com referência ao embate que resultou na primeira cena descrita na narrativa (por exemplo, I.1.3.4, V.32.2.5), à luta entre os dois bandos de boukoloi no livro I (I.28.1.8, I.29.5.4), à decisão dos cidadãos de Delfos de empreender uma perseguição contra os tessálios acusados de raptar Caricleia (IV.19.3.9), ao ataque do pirata Traquino e de seu bando ao navio mercante fenício (V.26.1.3) e ao relato da mulher em Bessa sobre a batalha entre os boukoloi e o exército persa na qual ela perdeu o filho (VI.12.3.5). O emprego da palavra $\pi$ ó $\lambda \varepsilon \mu$ $\varsigma$ poderia ser entendido em uma acepção mais geral, como "luta", mas Heliodoro parece ter desejado, de fato, aproximar soldados e bandidos, como 
discutiremos na sequência. Além disso, a grandiosidade da investida dos boukoloi contra a cidade de Mênfis, que eles planejavam sitiar após derrotar a guarda persa em Bessa, demonstra que o bando liderado por Tíamis poderia também representar uma ameaça concreta não só a indivíduos livres, mas à autoridade persa.

Assim, se no livro IX, Hidaspes, rei da Etiópia, é caracterizado de forma positiva por meio da sua magnanimidade para com inimigos de guerra, o romancista também explora o comportamento dessas figuras socialmente marginalizadas no que diz respeito a sua organização hierárquica e ética diante de conflitos violentos. Nesse sentido, o desempenho de Tíamis no comando de um exército não de soldados, mas de um bando de boukoloi, fornece um contraponto importante a Hidaspes, representando ao mesmo tempo um modelo de masculinidade contra o qual comparar a caracterização do herói Teágenes. Sendo um personagem de origem nobre, que se tornou bandoleiro "por necessidade", Tíamis leva uma vida que poderia se tornar a de Teágenes, como se insinua diversas vezes no romance. Porém, enquanto o herói romanesco é distanciado de sua família e sociedade para voltar para ela no fim da narrativa - ou, no caso específico de As Etiópicas, para ser aceito por aquelas da heroína -, os bandidos, como observa Hopwood (1998, p.202), "estão perdidos em um rito de passagem" e nunca ultrapassaram o limiar de cidadania do homem adulto responsável.

Tíamis, porém, terá a oportunidade de se reintegrar, e sua ação no comando dos boukoloi não é a de alguém apenas interessado em pilhagens e em lucro, mas de um líder politicamente motivado, de modo que em Heliodoro está representada também a confusão histórica comum ao período entre bandidos e rebeldes políticos. Lonergran (2010, p.70) observa que nos relatos historiográficos e representações literárias a distinção entre bandido, rebelde e inimigo de guerra (apenas este último identificado com um Estado) em Roma era tênue: ${ }^{23}$

A diferença é frequentemente arbitrária e depende da atitude e das intenções do autor. Com a imprecisão inerente à terminologia, vemos autores romanos usarem essas classificações de modo intercambiável de acordo com a direção de suas narrativas.

\footnotetext{
${ }^{23}$ Cf. Grünewald (2004, p.33-56). Sobre bandidos em Roma e sua representação no romance latino, sobretudo em Apuleio, cf. Riess (2000-2001 e 2001).
} 
Além disso, o próprio termo boukolos, que significa "pastor", mais especificamente "boiadeiro", tem uma utilização complexa no período e convida à confusão entre bandidos e rebeldes políticos. Os boukoloi também são personagens de outros dois romances: Leucipe e Clitofonte e As Efesíacas, mas neste último são

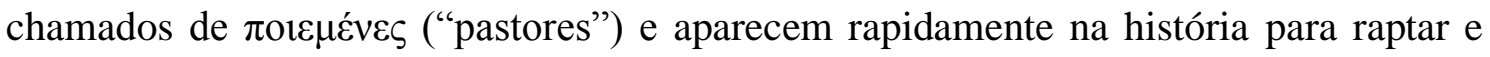
vender o herói Habrocomes como escravo (III.12). Rutherford (2000) recentemente argumentou de modo interessante que a presença desses bandoleiros nos romances pode ser influência de uma tradição narrativa em prosa egípcia conhecida como ciclo de Inaros-Petubastis. Isso contraria uma visão mais comum de que os bandidos egípcios estariam presentes no romance por influência de acontecimentos históricos do período imperial, baseada principalmente no relato de Dion Cássio (72.4) de que um grupo de boukoloi teria provocado uma revolta no Egito no ano de 171 d.C. ${ }^{24}$ Sua caracterização, porém, varia nos testemunhos e Winkler (1980) levantou a hipótese de terem existido dois grupos chamados de boukoloi: um de rebeldes políticos, como os de Aquiles Tácio e os mencionados por Dion Cássio, e outro grupo mais antigo, atestado por Eratóstenes (apud Estrabão XVII.1.19), formado, de fato, por pastores de animais que repeliam os estrangeiros da costa egípcia. ${ }^{25}$

Heliodoro também deixa os limites que definem um bandido senão mais tênues, pelo menos um pouco mais complexos, ora quando considera Teágenes e Caricleia prisioneiros de guerra em situações diversas, ora quando a heroína é vítima de um rapto (forjado) da parte do herói. Isso acontece com a presença do comerciante Nausicles, por exemplo. Amante de Tisbe, que ele pretendia vender à rainha da Etiópia, ele paga uma grande soma a Mitranes, chefe da guarda persa em Mênfis, para que este e seus

\footnotetext{
${ }^{24}$ Sobre a revolta dos boukoloi, cf. Alston (1999).

${ }^{25}$ Rutheford (op.cit.), por sua vez, observa que, embora os fragmentos do ciclo Inaros-Petubastis sejam do período imperial, acredita-se que as histórias possam datar do período helenístico. Em uma dessas histórias, há um grupo de guerreiros cujo nome ora é traduzido como "asiáticos", ora como "pastores". Os romancistas gregos poderiam, assim, ter adaptado um motivo egípcio nas suas narrativas. O crítico sugere ainda que o sacrifício humano feito pelos boukoloi mencionado no relato de Dion Cássio (que se assemelha ao Scheintod de Leucipe em Aquiles Tácio nas mãos dos bandoleiros) pode ser um indício de que o historiador tenha sido influenciado pela ficção. Contra a hipótese de Winkler, o crítico argumenta que os rebeldes citados pelo historiador romano podem ter se autodenominado boukoloi inspirados justamente pelos heróis do ciclo de Inaros-Petubastis. Além disso, em um dos fragmentos um grupo de treze boukoloi é liderado por um sacerdote. Isso faz lembrar o bando de As Etiópicas, pois Tíamis acaba por assumir a sua devida posição como sacerdote em Mênfis.
} 
soldados ajudassem-no a recuperá-la das mãos do boukoloi - ela havia sido raptada por Termoutis, que estava apaixonado por ela. Quando eles chegam ao acampamento de Tíamis e seu bando, porém, encontram apenas Teágenes e Caricleia. De olho no lucro que poderia obter, alegando que ela é Tisbe, Nausicles leva a heroína consigo. Não era por amor que ele desejava recuperar a ateniense, mas por causa da soma em dinheiro que ela lhe renderia sendo vendida na Etiópia. Ao levar Caricleia para casa, sem saber que o homem que hospeda, Calasíris, é como um pai para ela, não a cede de graça, mas somente em troca de uma ametista muito valiosa (V.13-14). Nausicles é chamado de

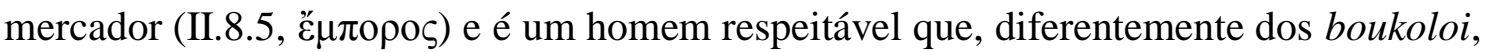
não vive em bando, não habita regiões afastadas da cidade (em Heliodoro, eles são moradores dos pântanos $)^{26}$ e não pratica, na narrativa, ele próprio a violência que lhe rende prisioneiros, contratando para isso os serviços da guarda persa, mas ao vender pessoas livres, sua atividade tem natureza muito parecida com a dos bandidos. ${ }^{27}$

Teágenes, por sua vez, cai nas mãos de Mitranes e, ainda que seja resgatado por Tíamis pouco depois, em Mênfis, Arsace declarará ter poder sobre ele porque ele é seu

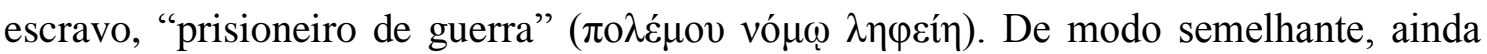
que tenha se tornado prisioneira de um bando que não tem a autoridade de uma violência “institucionalizada" como é a da guarda persa, Caricleia se dirá honrada com o pedido de casamento de Tíamis, uma vez que ela não passa de "uma mulher capturada

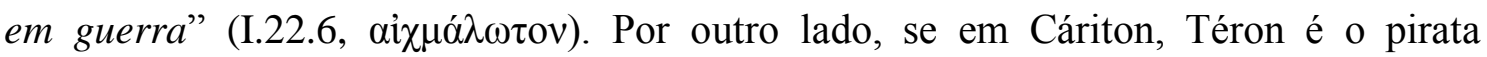
responsável por transportar a heroína Calírroe de Siracusa à Jônia, a viagem de Caricleia tem início em um rapto empreendido por Teágenes, arquitetado por Calasíris e representado, ainda que tenha acontecido com o consentimento dela, como uma espécie de conflito bélico. ${ }^{28}$

Durante a noite, nas palavras de Calasíris, "homens armados" entraram no quarto de Caricleia: “Teágenes era general dessa guerra erótica, tendo reunido jovens

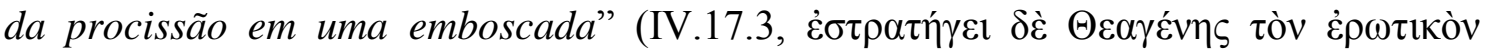

\footnotetext{
${ }^{26}$ Cf. Panagakos (2004, p.194-263) para o estudo da descrição das moradias dos bandidos no romance antigo.

${ }^{27}$ Cf. I.19.5 em que Tíamis explica como era sua conduta com relação a pessoas livres que o bando aprisionasse.

${ }^{28}$ O rapto de Caricleia faz lembrar a lenda segundo a qual teria se passado a escolher a Pítia de Delfos dentre mulheres mais velhas depois do seu sequestro e violação por um jovem tessálio (Diodoro, Biblioteca Histórica, XVI.26.6). Cf. Lalanne (2006, p.272).
} 


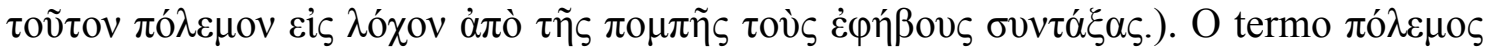
será retomado adiante, mas não mais com valor metafórico (IV.19); o próprio Calasíris exortará os cidadãos de Delfos a pegar em armas e perseguir os inimigos. Reunidos em

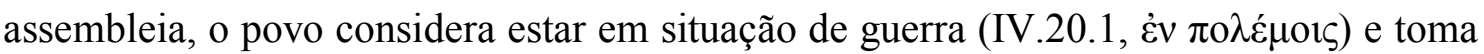
várias decisões: perseguir os raptores, empalá-los vivos se capturados, banir seus descendentes de tomar parte da missão sagrada em Delfos e não mais permitir que a sacerdotisa de Ártemis carregue a tocha na competição de corrida em armas, momento no qual Teágenes teria se apaixonado por Caricleia. ${ }^{29}$ É o próprio herói, quase no final do romance, quando Cáricles surge em Méroe em busca da sua filha adotiva, que vai

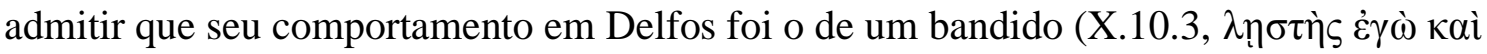

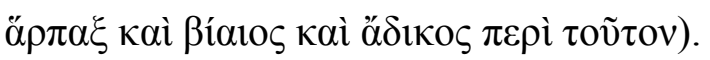

Heliodoro tem, desse modo, claramente maior interesse do que os demais romancistas na representação da vida e da ética de bandoleiros e piratas. A primeira cena que abre o romance introduz imediatamente o leitor no mundo perigoso e excitante dos boukoloi (I.1.1): ${ }^{30}$

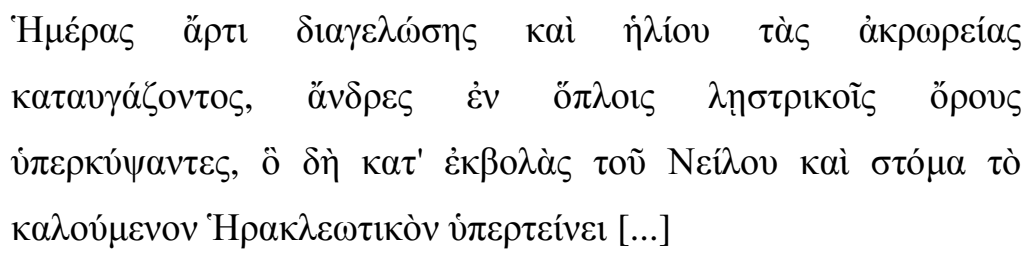

Quando o dia começava a sorrir e o sol a iluminar o cume das montanhas, homens armados como bandidos estavam à espreita sobre um monte que se estende ao longo da desembocadura do Nilo, chamada boca heracleótica [...]

O leitor acompanha por meio desses homens que se vestem como bandidos o cenário às margens do Nilo e as inferências que eles fazem diante de situação tão inusitada, observando tudo "como uma audiência no teatro, sem compreender a cena"

\footnotetext{
${ }^{29}$ Hilton (2005) vê exagero e futilidade nas decisões do povo de Delfos, do que depreende uma representação irônica da guerra da parte de Heliodoro. No entanto, Hunter (1993) faz uma melhor análise da passagem, sugerindo que se estabelece nesse momento que a história de Teágenes e Caricleia jamais poderá se repetir.

${ }^{30}$ Sobre o caráter cinemático dessa cena inicial, cf. Winkler (2000-2001). Sobre a metáfora do sorriso do sol, cf. Whitmarsh (2005b).
} 


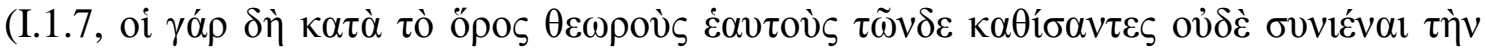

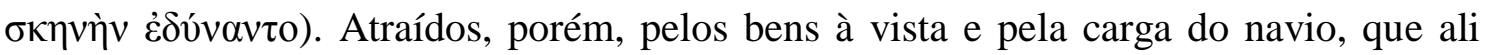
estava ancorado intacto, os bandidos descem em direção à praia e veem Caricleia e Teágenes. A imagem dela (I.2.1-2) faz lembrar a deusa Ártemis, não só pela beleza e nobreza, mas também pelo fato de ela carregar arco e aljava. Teágenes parecia terrivelmente ferido, à beira da morte, mas ainda assim era possível distinguir a sua

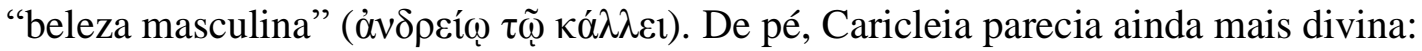

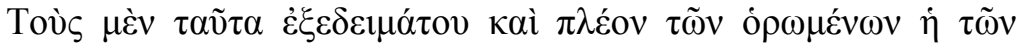

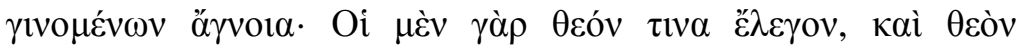

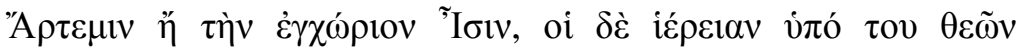

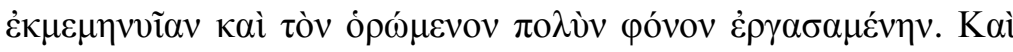

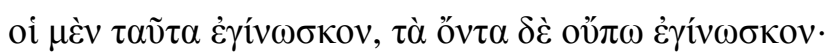

Eles estavam aterrorizados, mais pela ignorância do que havia acontecido do que apenas pelo que viam. Uns diziam que ela era uma deusa, Ártemis ou Ísis, como a chamam na região, outros que ela era uma sacerdotisa levada à loucura por um deus e que a grande matança que observavam era obra sua. E isso era o que sabiam, sem ainda saber a verdade.

Ao observarem Caricleia beijando Teágenes, porém, eles julgam o comportamento estranho para uma deusa - "poderia uma deusa beijar um cadáver (vยкৎóv) com tanta paixão?" (I.2.7) - e, ao se aproximarem, ela não se intimida nem pela sua estranha cor nem por sua aparência de bandidos. É quando ela diz que a maioria dos mortos ali havia morrido uns pelas mãos dos outros e que os dois tinham agido apenas em legítima defesa, defendendo-se de um ataque contra sua castidade ( $\tau \tilde{\eta} \varsigma$

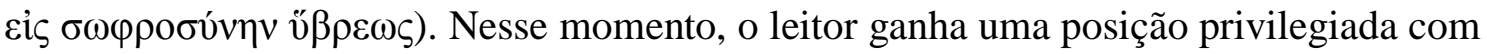
relação aos bandidos, pois pode compreender as palavras de Caricleia, ao passo que eles apenas a observam atônitos, já que desconheciam o grego. ${ }^{31}$

O que a heroína diz, contudo, está em desacordo com aquilo que eles haviam acabado de observar e, de certa forma, seu raciocínio não está totalmente equivocado:

\footnotetext{
${ }^{31}$ Heliodoro se mostra preocupado ao longo de toda a narrativa em chamar a atenção para os diferentes idiomas utilizados pelos seus personagens e a consequente dificuldade de comunicação entre eles.
} 
aquela que eles julgavam uma deusa era responsável pela carnificina. Não apenas, como o leitor descobrirá somente no livro $\mathrm{V}$, porque ela provoca uma disputa entre dois homens, mas porque fica claro pela descrição dos cadáveres observados pelos bandidos

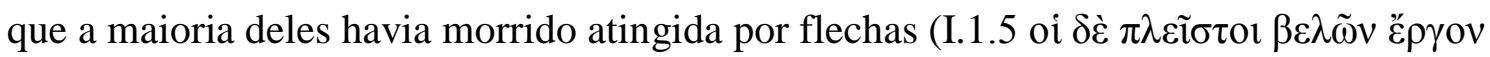

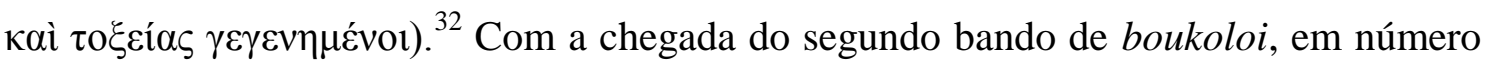
muito maior, o que afugenta o primeiro, apresenta-se outra conclusão errônea: eles julgam que a carnificina havia sido obra daqueles que fugiam. Dessa vez, porém, não pensam que Caricleia seja uma deusa - Tíamis deixará claro adiante que havia reconhecido sua vestimenta como a de uma sacerdotisa. Presos, o líder do bando cede seu cavalo a ela e a Teágenes, fazendo-se "escravo de seus prisioneiros" (I.4.3). ${ }^{33}$

Esse início dá ao leitor uma amostra da força de Caricleia. Mesmo entre bandidos e piratas, é ela quem parece tomar as iniciativas em diversos momentos: os boukoloi podem até ter notado a "beleza masculina" de Teágenes, mas se Caricleia é, para eles, a deusa Ísis, ele, ainda vivo, é chamado de “cadáver”. Konstan (1994, p.98) sugere que a atuação dela na luta contra os piratas faz parte da representação da simetria sexual específica do romance grego, mas é inegável que Teágenes é um dos heróis romanescos de menor brilho e parece um personagem fraco se comparado a Caricleia. Assim, por exemplo, Anderson (1982, p.88) o considera "o tempo todo uma marionete da heroína" e Haynes (2002, p.91) reconhece que ele é "ofuscado pela sua força emocional". Ao mesmo tempo, o herói também é posto em comparação com Tíamis, que ocupa uma posição de liderança, submetendo os heróis aos seus comandos. É interessante notar, aliás, que quando ele anuncia o desejo de desposar Caricleia, não é Teágenes quem se manifesta, mas ela própria quem toma a palavra, ainda que observe que seria mais apropriado se o "irmão" dela falasse em seu lugar (I.21.3). Primeiramente ela concorda com o matrimônio e em seguida persuade o bandido a postergá-lo - e sua retórica é tão convincente que até Teágenes é levado a acreditar que ela era mesmo favorável ao casamento. Caricleia sai-se muito bem enganando Tíamis e,

\footnotetext{
${ }^{32}$ Haynes (2002, p.72): "Direct force, however, is something that the heroine, like her other counterparts, gets few chances to employ. Her skill at archery does allow her to make a decisive contribution to the pirates' brawl, killing many of the combatants, but the identification of this form of weaponry with Artemis, coupled with Charikleia's ability to avoid directly sullying her hands with blood, renders her actions acceptable".

${ }^{33}$ Woronoff (2001, p.201): "D'une façon générale, chez Héliodore, la beauté subjugue les êtres, elle est même capable d'arrêter la violence".
} 
com o avançar da narrativa, o leitor descobrirá que ela teve em Calasíris um grande mestre no uso dos métodos ludibriadores para escapar dos pretendentes. Ainda em Delfos, a estratégia de fingir concordar com um casamento é utilizada pela primeira vez (IV.13), já que seu pai adotivo desejava dá-la em casamento ao seu primo Alcamenes. Ela o faz inicialmente sem saber o motivo da mentira, porque Calasíris lhe diz que é mais fácil para uma mulher pôr em prática um plano que ela desconhece. Novamente guiada pelo egípcio, entre os piratas a heroína se mostrará satisfeita (V.26) com a ideia do casamento com Traquino.

Ainda que Tíamis seja visto de uma perspectiva mais positiva que bandidos de outros romances e comande os boukoloi do lado da justiça na sua ação para retomar seu posto de sacerdote em Mênfis, seu bando, por sua vez, não gera nenhuma simpatia e Cnemon considera que seu líder era o único capaz de controlá-lo: "pois essa raça dos boukoloi é sobretudo traiçoeira, ainda mais agora que eles já não têm o chefe que lhes

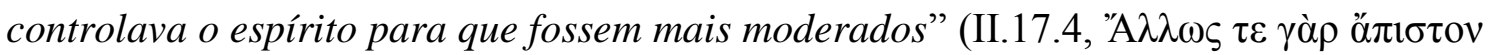

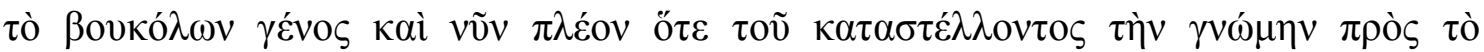

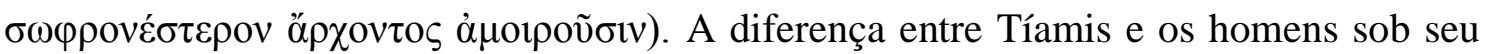
comando é marcada algumas vezes. Os boukoloi, por exemplo, mantêm uma aparência assustadora (II.20): logo que se vê livre dos bandidos, Cnemon corta os cabelos, que ele havia deixado crescer para ficar mais parecido com eles. Ele o faz por desejar não mais inspirar terror em quem o visse, pois considera que os cabelos longos tornam os amantes mais belos e, por outro lado, fazem um bandido ainda mais assustador. Tíamis, contudo, é retratado como um homem atraente, capaz de rivalizar com Teágenes em beleza - ao menos é o que pensa Arsace quando pode observá-los lado a lado em Mênfis (VII.4.2.), reacendendo uma antiga paixão (VII.2.2). O próprio Cnemon, que era prisioneiro do bando há algum tempo, diz a Caricleia e Teágenes (I.19.2) que o capitão

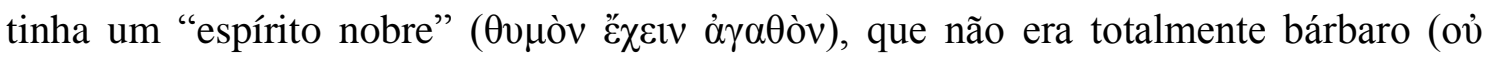

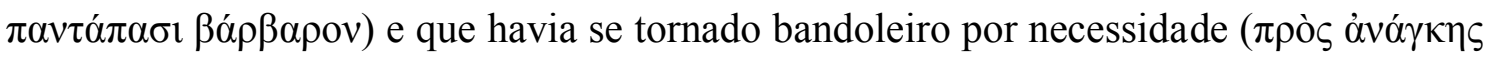

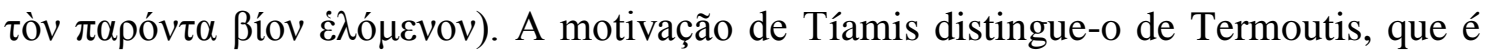
um duplo seu e que afinal recebe sua punição merecida (II.20.2), morrendo pela picada de uma serpente. ${ }^{34}$

\footnotetext{
34 "Termoutis" segundo Eliano (Hist.Anim, X.31) era o nome dado pelos egípcios a uma espécie de serpente sagrada cujo veneno era mortal apenas para os criminosos.
} 
A forma como Tíamis se comporta quando se apaixona por Caricleia contrasta também com a atitude dos outros pretendentes que ela tem ao longo do romance. Ele apresenta-a ao bando como parte do butim que deveria ser partilhado de comum acordo com todos os membros, pedindo permissão não apenas aos seus companheiros para tomá-la como sua única parte na divisão, mas também reconhecendo que um casamento deve ser realizado pela vontade de ambas as partes. Além disso, quando Caricleia explora a autoimagem de Tíamis como membro de uma família de sacerdotes, pedindo que o casamento seja postergado até o momento em que ela possa visitar um templo de Apolo para abandonar o seu próprio sacerdócio, ele concorda (ainda que com dificuldade), demonstrando que também é capaz sophrosyne. Ele, aliás, na sequência evita encontrá-la, para não atiçar sua paixão, um comportamento que faz lembrar o do irrepreensível Ciro na Ciropédia de Xenofonte, quando ele se recusa a conhecer Panteia.

Outro aspecto interessante do romance é como o autor trata da proximidade e das diferenças entre bandidos e soldados, algo notado por outros autores do período imperial. Há uma semelhança inicial entre as duas categorias porque ambas portam armas, mas aqueles agiriam de acordo com seus "desejos perversos", desafiando o monopólio da violência que caberia ao Estado, agindo sem regras ou hierarquia bem estabelecidas (cf. Hopwood, 1998). Nesse sentido, é possível considerar que o comando de Tíamis é representado de modo positivo quando ocorre a partilha do butim, quando, aliás, ele se dirige aos homens como "soldados companheiros" (I.19.3, őv $\delta \rho \varepsilon \varsigma$ $\sigma v \sigma \tau \rho \alpha \tau \imath \tilde{\omega} \tau \alpha \imath)$. O tom democrático que seu discurso possui (I.19) e a concordância de seus companheiros em lhe cederem Caricleia como sua parte na divisão enfatizam a organização do bando e a legitimidade da posição ocupada por seu líder. Essa situação contrasta com a dos piratas no livro $\mathrm{V}$, ainda que essa relação possa, por outro lado, talvez também evidenciar a fragilidade das relações hierárquicas em um grupo de "foras da lei", em que qualquer momento um código de conduta pode ser quebrado lembrando que a palavra grega $\lambda \eta\rceil \sigma \tau$ s identifica tanto o pirata quanto o bandido que age em terra.

O que motiva o ataque do bando do pirata Traquino ao navio fenício é seu desejo por Caricleia (V.26.1) e, quando os preparativos para a cerimônia de casamento estão em curso, Calasíris encontra um modo de impedi-lo atiçando Peloro contra seu chefe. Mas a disputa não é apenas porque ambos estão apaixonados por Caricleia, mas também porque Peloro considera que Traquino está violando as regras do código dos piratas, segundo o qual o primeiro a invadir um navio atacado é também o primeiro a escolher 
seu prêmio (V.30.3 e 31.3). Se essa regra não for obedecida, Peloro promete "bodas

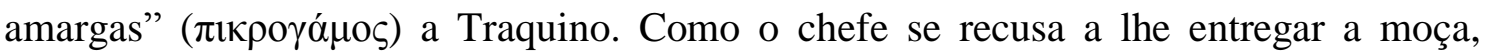
alegando que os subordinados devem obedecê-lo (V.31.4), Peloro responde que se trata de uma "lei tirânica" e assim tem início a luta que resultará na cena de carnificina que abre o romance.

Esses fatos, de certa forma, enfatizam a ideia de que Tíamis é diferente dos outros, uma espécie de "bandido nobre", mas Heliodoro não deixa de marcá-lo também como bárbaro e violento. A caracterização positiva de Tíamis é em parte desfeita quando ele mostra seu caráter bárbaro ao decidir matar Caricleia. A análise mais negativa desse comportamento é feita por Hilton (2005). O crítico argumenta que a guerra é representada de modo irônico na cena de batalha do livro I entre os dois bandos de boukoloi. Ele observa que por uma série de intertextos (especialmente Il. VI.492 e Aristof.Lis.520), Tíamis é representado como um "fanfarrão covarde", um mero $\dot{\alpha} \lambda \alpha ́ \zeta \omega v$ (p.79). Ele alegaria de forma hipócrita que as mulheres têm pouca importância em tempos de guerra, mas ao mesmo tempo garantiria que Caricleia ficasse em segurança na caverna distante da batalha. De fato, não são só palavras de Heitor que

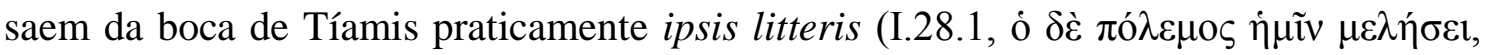

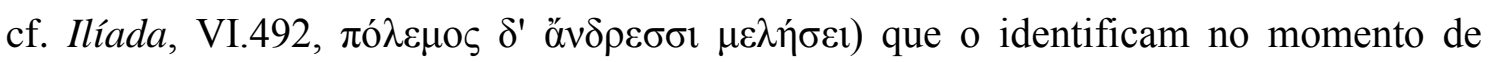
preparação para o embate com Heitor, mas também a cena (I.27.3) em que ele aparece polindo seu elmo e afiando a lança (cf. Ilíada, VI.321ss). Ambos os intertextos, por outro lado, ajudam a identificar Caricleia com Andrômaca - e o narrador ainda enfatiza a preocupação do egípcio com ela, ao dizer que ele parecia ter mais receio pela heroína do que por si próprio (I.28.1). Hilton não deixa claro, mas a passagem em que ele percebe a suposta alegação hipócrita de Tíamis deve estar no discurso de exortação que o bandido faz aos seus companheiros (I.29.6):

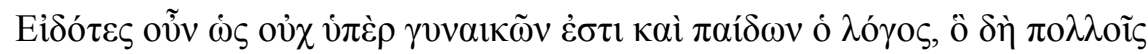

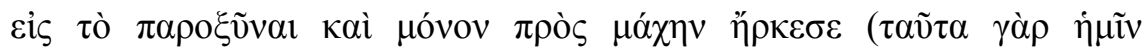

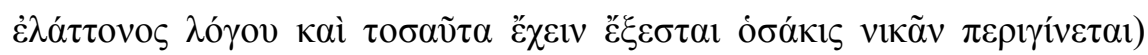
$[\ldots]^{35}$

\footnotetext{
35 Aqui adoto a sugestão de Morgan em sua tradução de Heliodoro para a coletânea organizada por

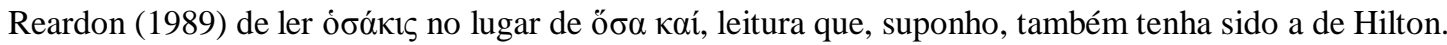


Temos ciência, portanto, de que a questão aqui não diz respeito a nossas mulheres e filhos, ainda que para muitos somente isso baste como incentivo a encararem a luta (pois são para nós questão de menor importância e será possível substituí-los sempre que sairmos vencedores) $[\ldots]$

Tíamis conclui seu breve discurso dizendo que os boukoloi lutam pela própria vida, pois nunca houve uma guerra de bandidos $(\lambda \eta\rceil \sigma \rho$ เкò $\varsigma$ ó $\lambda \varepsilon \mu \circ \varsigma)$ que terminasse em trégua ou em tratado de paz; vencer significa viver, perder significa morrer. Assim, de fato, ele é representado, segundo sugere Hilton, como alguém que age contrariamente ao que diz, mas o fato é que isso é algo até mesmo esperado daquele que está numa posição de liderança. Os romancistas chamam a atenção para a necessidade de um general ou de um governante saber construir um discurso aos seus subordinados, às vezes dizendo o contrário do que se deseja, a fim de se mostrar um bom líder. É o que ocorre com Quéreas, no romance de Cáriton, quando, ao ser informado da derrota das forças terrestres egípcias, é aconselhado por Calírroe e finge não saber de nada, provocando em seguida uma situação propícia para que os próprios soldados sob seu comando sugerissem que eles se dirigissem, então, à Siracusa (VIII.2), o que era sua intenção desde o início. Em Heliodoro, o grande exemplo é o discurso de Hidaspes no último livro do romance (X.16), em que, ao mesmo tempo que ele argumenta que sua filha Caricleia deve ser sacrificada, o narrador informa que ele havia escolhido bem as palavras para que o povo reagisse como ele desejava, i.e., impedindo-o de fazer aquilo que ele dizia ser necessário fazer. ${ }^{36}$ Para Tíamis, faz todo o sentido dizer aos bandidos que eles não devem lutar pensando na família mas em sobrevivência; essa exortação serve como argumento pela não rendição e pela permanência no campo de batalha, ainda que ele próprio demonstre que essa atitude de indiferença não é possível. Por outro lado, pode também se considerar que a preocupação do egípcio com Caricleia (mesmo que demonstrada da forma errada) é outro elemento que o aproxima do herói Teágenes e o afasta da ética selvagem dos bandidos.

Winkler (1980), por sua vez, tem uma visão menos negativa da atitude de Tíamis. A motivação para o assassinato seria múltipla: o narrador comenta que os bárbaros tomam atitudes como essa em períodos de guerra talvez em razão da crença de que eles vão se unir aos seus amados no pós-vida (I.30.6). Por outro lado, Tíamis

\footnotetext{
${ }^{36}$ Para uma análise desse discurso, cf. Morgan (2006).
} 
acredita estar cumprindo a profecia de seu sonho quando decide matar Caricleia. “Ambas as motivações estão, portanto, relacionadas de alguma forma com religião: uma é a realização de um oráculo enganoso, a outra é obediência a uma crença equivocada" (idem, p.169). Mas o narrador ainda dá uma terceira explicação (I.30.6): querer impedir que a pessoa amada caia nas mãos dos inimigos e sofra violências

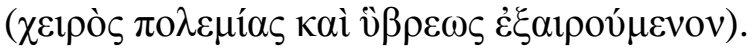

Dois elementos, porém, parecem-me necessária e fortemente negativos na caracterização de Tíamis nessa passagem. Ele, de fato, é de algum modo guiado por uma crença religiosa, mas se refere à morte de Caricleia, de forma um tanto oblíqua, como um sacrifício aos deuses, quando diz a Termoutis, prestes a matar um animal, que

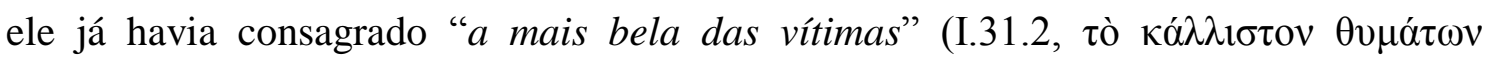

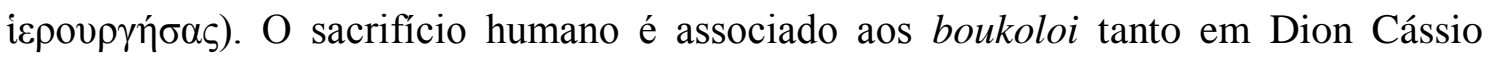
(72.4) quanto em Aquiles Tácio (III.15), e em ambos os registros se pratica também o canibalismo. Em Xenofonte de Éfeso, o bando de Hipothoo tem igualmente a prática do sacrifício, que garantiria o favor de Ares (II.13). Como observa Watanabe (2003, p.19), porém, nas mãos dos bandidos do romance grego "o sagrado rito do sacrifício se torna um ultrajante ato criminoso, o que indica sua posição antípoda com relação à cultura grega normativa na economia moral do romance".

Além disso, se anteriormente Tíamis havia demonstrado ser também possuidor de sophrosyne, autocontrole, dominando seu desejo para atender ao pedido de Caricleia de postergar o casamento, o narrador observa que ele não se preocupou com os perigos

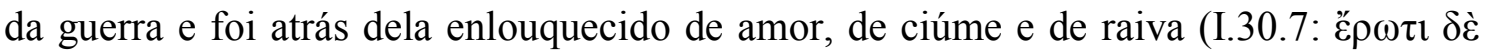

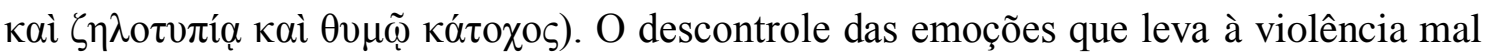
dirigida é um elemento importante na caracterização negativa de personagens masculinos nos romances e, em Heliodoro, é característico não só de bárbaros - como Tíamis, Aquemenes (VII.29) e os piratas -, mas também toda a trama ateniense de Cnemon é pontuada por ações raivosas dos envolvidos. ${ }^{37}$ Um contraponto importante é Hidaspes, que furioso (X.2.3, ópүท́v) porque a cidade de Siene se recusa a se render espontaneamente, pensa em um estratagema que possa livrar o exército de um cerco longo e cansativo e ao mesmo tempo provocar o menor número de baixas. $\mathrm{O}$

\footnotetext{
${ }^{37}$ Para uma análise da história de Cnemon em contraposição a de Teágenes e Caricleia, cf. Morgan (1989b).
} 
descontrole de Tíamis faz com que ele dirija a sua violência não aos inimigos que esperavam por ele no campo de batalha, mas à mulher que ele ama.

Entregando-se ao combate sem expectativa de sobrevivência, uma vez que o número de inimigos era muito superior ao do bando que comandava, é Tíamis, porém, quem é comparado ao herói homérico que morre em batalha, deixando mulher e filho. Teágenes e Cnemon, por sua vez, fogem da luta (I.31) e, mesmo que o narrador diga que eles o fazem "não inteiramente por medo", chama-se a atenção para o fato de que ele é, sim, um motivador da fuga dos dois personagens. E novamente se ressaltará logo na sequência a obstinação de Tíamis, o único dos três que permanece para lutar, seja por orgulho, seja por ser incapaz de imaginar a vida sem Caricleia. O trecho evidencia a intenção do narrador de comparar os personagens como rivais ao amor da heroína. Como nota Panagakos (2004, p.161), o herói é sempre comparado a líderes de bandidos porque enfatizam "as forças e as fraquezas deles e ainda, por meio dessa comparação, revelam seu potencial para serem tão bons ou melhores do que o herói”. O que está em questão, porém, não é se um homem que foge do combate por medo é menos digno da mão de Caricleia, pois não se pode sugerir que um homem que tentou assassiná-la seja um melhor par, mas o contraste entre suas atitudes leva à dúvida sobre a superioridade ou não de Tíamis no que diz respeito à andreia, a "coragem masculina". Afinal, a observação de Watanabe (2003, p.2) sobre o bandido Hipothoo em As Efesíacas parece fazer sentido para a relação entre herói-bandido também em Heliodoro:

Ele é representado ao longo de boa parte do romance como um personagem antitético ao passivo Habrocomes; a antítese é particularmente marcada em sua capacidade como arquibandido, que em vez de se submeter à violência criminosa, escolhe exercêla no topo da hierarquia.

Teágenes em nenhum momento toma parte de um empreendimento militar no romance, assumindo a liderança de um grupo, como acontece com Quéreas, no romance de Cáriton de Afrodísias. E mesmo sua atuação na luta contra os piratas não é exatamente excepcional, ao menos pelo que se pode imaginar a partir do que conta Calasíris para Cnemon (V.32). É verdade que o egípcio prefere salientar, na sua descrição do embate, a influência positiva da presença de Caricleia no ânimo e no vigor de Teágenes para a luta, mas Heliodoro parece querer recusar-lhe uma glória fácil tanto 
no duelo contra Peloro, quanto no extermínio dos demais piratas, pois, como se sabe desde o início da narrativa, a principal responsável pela matança havia sido Caricleia com seu arco e flecha.

Além disso, quando a guarda persa, sob o comando de Mitranes, e Nausicles chegam ao acampamento (V.6-7), o herói sugere que o casal se renda de uma vez por todas, desista de enfrentar os sucessivos males que se assemelham a uma peça teatral, e se entregue à morte: "por que então não interrompemos essa trama trágica e nos

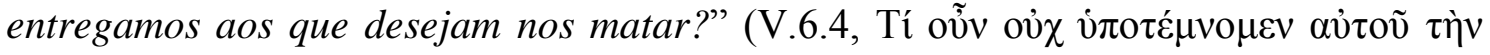

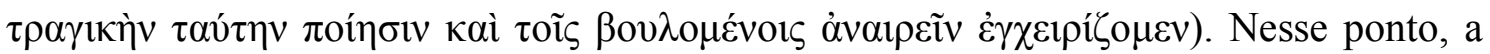
sugestão de Teágenes pode bem ter como função deixar claro ao leitor que não foi por medo de morrer que ele havia pouco antes evitado enfrentar o combate, pois ele se mostra disposto a abraçar a morte caso Caricleia esteja com ele. Porém, ela é contrária ao plano, argumentando que a morte não é garantida mesmo que se entreguem a mãos inimigas e que no passado, em situações ainda piores, eles haviam conseguido se salvar. “'Façamos como você quer', disse Teágenes, que seguia o comando dela como se

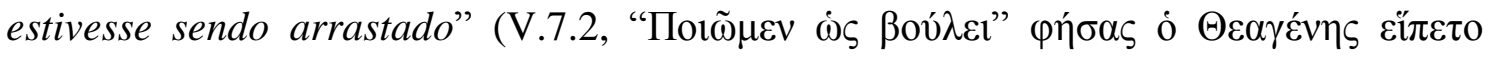

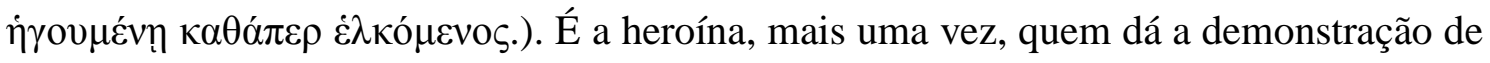
força para lidar com situações adversas. A atitude de Teágenes contrasta, aliás, com toda uma ideologia de perseverança presente no conselho que - o leitor conhecerá adiante na narrativa -, Calasíris lhes havia dado, quando eles se sentem ameaçados pelos piratas: enfrentar o perigo, ainda que fosse para ter uma morte digna e corajosa

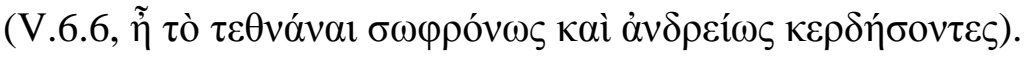

Heliodoro, porém, em outras passagens parece querer indicar que Teágenes não tem nada a dever em termos de coragem para Tíamis: em ocasiões diversas os bandidos refletem que o herói seria um bom acréscimo ao bando (I.4.2, V.26) e sua capacidade de substituir Tíamis no comando dos boukoloi é reconhecida por ele próprio, quando pede ao grego que assuma sua posição caso venha a falecer no duelo contra o seu irmão Petosíris (VII.5.5). Além disso, o que se sucede na caverna, para onde se dirigem o herói e Cnemon depois que escapam do combate, deixa claro que os dois são muito diferentes, o que enfatiza o valor do herói. Isso acontece em três situações em que ele é contraposto ao ateniense. ${ }^{38}$ Quando Cnemon o reprova por ter derramado lágrimas sobre um cadáver que não era o de Caricleia, Teágenes responde zombando de forma irônica

\footnotetext{
${ }^{38}$ Cf. Jones (2012, p. 124-133).
} 


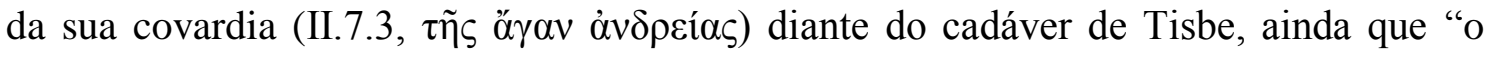

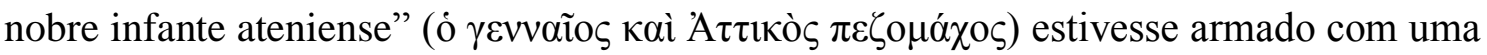
espada. Em seguida, quando Termoutis aparece nu e com cara de poucos amigos na caverna, sabendo que Tisbe havia sido assassinada, Caricleia e Cnemon recuam para o fundo da caverna - ela por precaução, mas mais por pudor, ele por suspeitar de algo ruim (II.13.2). Teágenes, porém, não se intimida, e ameaça o bandido. Por fim, ele aconselha Cnemon, que relutava, a partir com Termoutis em busca de notícias de Tíamis e despistá-lo no caminho: "mas crie coragem e mostre uma disposição mais

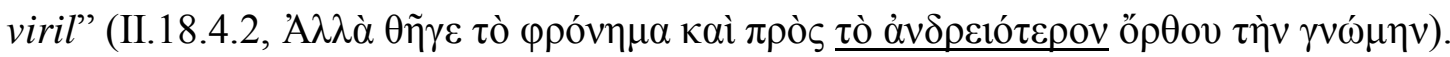

Parece que essa distinção entre a covardia de um e a valentia de outro é construída nesse momento da narrativa para afastar qualquer suspeita que pairasse a respeito da andreia de Teágenes. Mais adiante, o leitor poderá novamente pôr em perspectiva a atitude do herói de evitar o combate com os boukoloi quando Calasíris menciona a sua disposição de se envolver na luta entre os mercadores fenícios e os piratas (V.54.3). O egípcio e Caricleia conseguem segurá-lo e impedir que ele participe da luta, ainda que com dificuldade. São as palavras dela que parecem convencê-lo, porém, quando diz que ela morreria junto com ele. E é pelo amor de Caricleia que o herói afirma ter fugido da guerra entre os dois bandos de boukoloi, demonstrando, ao mesmo tempo, consciência de que sua atitude seria compreendida como covarde (II.1.2) e considerando que foi $\delta \varepsilon ı \lambda o ́ s$ e ǒv $\alpha v \delta \rho o \varsigma$ por nada, já que nesse momento ele acreditava que ela estava morta. Como valor maior do romance, o amor até permite certos desvios de conduta do herói com relação à andreia, servindo esses desvios, na verdade, como uma demonstração penosa do seu sentimento. Sem ninguém para impedi-lo de lutar, é o próprio Teágenes quem conclui que poupar-se para Caricleia é a melhor atitude a se tomar.

Sua linhagem, por outro lado, induz o leitor a acreditar que coragem e habilidade para guerra não devem lhe faltar, afinal ele surge em cena em Delfos como o tessálio líder da embaixada dos Enianes ${ }^{39}$ e descendente de Aquiles. Nas palavras de Calasíris (II.34.4):

\footnotetext{
${ }^{39}$ Homero chama de "helenos" apenas aos povos que habitam a Tessália. Calasíris explica a Cnemon que os Enianes (oi Aỉviãveৎ) eram os mais nobres de Tessália, descendentes de Heleno, filho de Deucalião (provavelmente uma criação posterior a Homero), e enviavam a Delfos uma embaixada para honrar Neoptólemo a cada quatro anos durante os Jogos Píticos (II.34).
} 


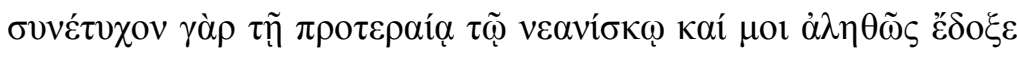

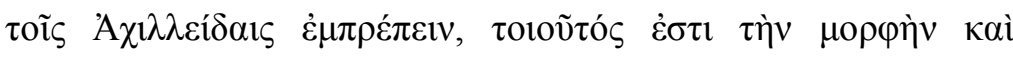

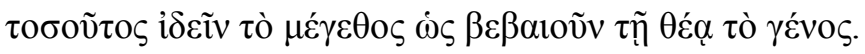

Encontrei-me com o jovem ontem e a mim ele pareceu verdadeiramente digno dos Aquileidas, tanta é a beleza e tamanha a altura que a mera visão dele é prova de sua estirpe.

Mais adiante Calasíris mencionará novamente que as qualidades físicas de Teágenes bastam para demonstrar essa ascendência heroica, mas acrescentará que seus temperamentos são diferentes: "não é nem arrogante nem altivo como [Aquiles], o

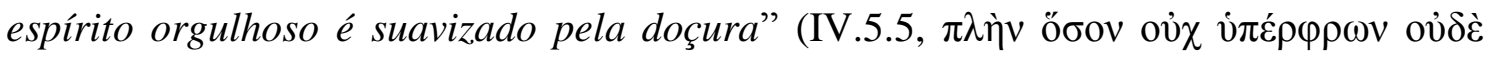

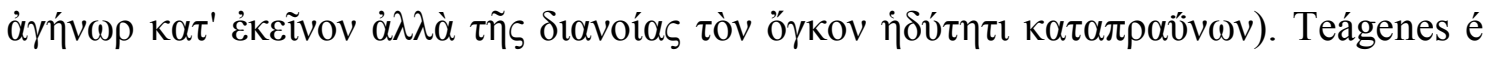
um Aquiles sem defeitos e isso significa que sua andreia excepcional não lhe trará como consequência um resultado prejudicial a si próprio e aos seus. Por outro lado, a possibilidade de conquistar glória em campo de batalha, reconhecida por Quéreas e Policarmo no romance de Cáriton, não se torna nunca uma questão para o herói de Heliodoro. Na oposição entre os vários conflitos violentos no romance e o grande episódio bélico do livro IX, fica claro que bandoleiros como Tíamis e piratas como Traquino é que devem sempre enfrentar a luta e morrer nela, se for o caso. A violência não é, em Heliodoro, a situação ideal para a demonstração de masculinidade.

Abordados pelos piratas, os mercantes fenícios a princípio recusam-se a se render, até que um dos assaltantes lhes ensina que uma guerra só é decidida pelo

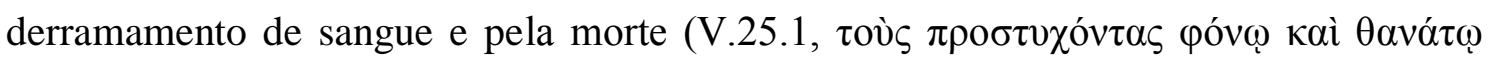

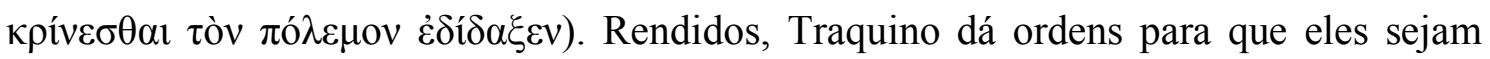
poupados, mas Calasíris observa que o que se seguiu foi o tipo mais cruel de guerra

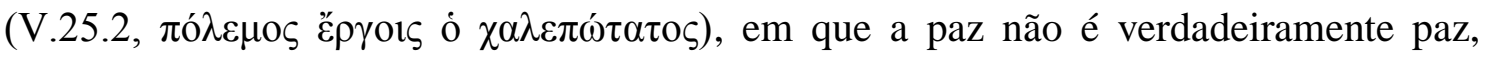
sendo os termos impostos ainda piores do que a luta: em pleno mar, eles deveriam abandonar o navio apenas com uma única túnica, sob a pena de serem mortos se levassem algo mais. No discurso de Tíamis a seus companheiros, também se ressalta a condição particular na qual lutam os bandidos (I.29.6): suas guerras não terminam

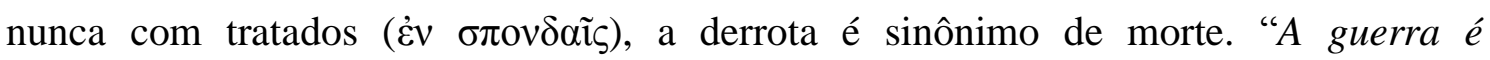
representada como um caos sangrento", como afirma Hilton (2005, p.79). 
Watanabe (2003, p.22-23) analisa de forma interessante uma passagem da Oração Alexandrina de Dion Crisóstomo (32.49) em que ele declara preferir morrer como bandido a agir como alguns efeminados da plateia. Ele diz que alguns cidadãos de Alexandria haviam chegado ao ponto de cometer suicídio por causa de seu envolvimento com flautistas ou outras pessoas do mesmo nível. "Morrer como bandido" ( $\lambda \eta\rceil \tau \varepsilon v ́ \omega v ~ \alpha ̉ \pi o \theta \alpha v \varepsilon \tilde{v})$ nesse caso significa morrer como homem, ainda que um homem

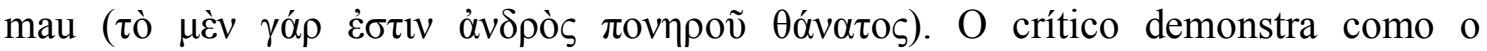
criminoso é representado por Dion Crisóstomo como senhor de seu destino, apesar de suas ações ruins, enquanto o comportamento de alguns alexandrinos pode ser

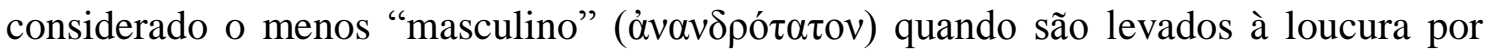
mulheres. Esse é um dos elementos que levam Watanabe a concluir que justamente por causa da sua passividade, o herói romanesco tem necessidade de um amigo que possa encarar com mais desenvoltura os perigos, sendo o bandido um exemplo de outro tipo de masculinidade apresentado de forma tão positiva quanto é a própria passividade do herói.

Nesse ponto, porém, parece-me que Watanabe minimiza o papel da violência na caracterização do bandido, analisando-o apenas como aquele capaz de assumir uma posição de liderança em um mundo brutal (e, por isso, representante de um ideal masculino positivo), sem levar em consideração que a suposta vitimização do herói tem como contrapartida a recusa de uma violência nociva e desnecessária (pois que não é resposta a uma ofensa) e sugere uma expectativa maior de reintegração à sociedade, algo que o bandido a princípio não possui. É certo que as qualidades de Tíamis na liderança de seu bando são enfatizadas, mas a vida dos piratas e bandidos é representada como uma guerra eterna e sangrenta da qual, diferentemente do herói, eles não podem fugir.

Quando estão se dirigindo a Bessa, Caricleia e Calasíris ouvem uma descrição da batalha entre boukoloi e armada persa feita por uma senhora (VI.13), a única pessoa viva entre muitos cadáveres de persas e alguns egípcios. A passagem parece mal costurada na narrativa, pois uma mãe que acabara de perder um filho faz uma descrição fria e pormenorizada do embate que acontecera havia pouco, informando também que Teágenes havia sido libertado pelo bando, que eles haviam feito uma emboscada contra o restante da armada e em seguida marchado em direção a Mênfis. Prometendo levá-los à cidade depois de realizar alguns ritos, a velha conduz um ritual de necromancia e seu filho revive momentaneamente para reprovar sua conduta, prever a morte do irmão e da 
própria mãe e, por fim, assegurar o destino feliz de Caricleia. O episódio mais uma vez ressalta a relação dela e de Calasíris com Odisseu, dessa vez aludindo à Nekuya do herói, ${ }^{40}$ mas sua função na narrativa não faz relevar o fato de que ele soa incongruente e inverossímil. Importa-nos, porém, chamar a atenção para o aspecto da vida dos boukoloi que é novamente enfatizado em seu discurso: a velha diz que eles são os homens mais

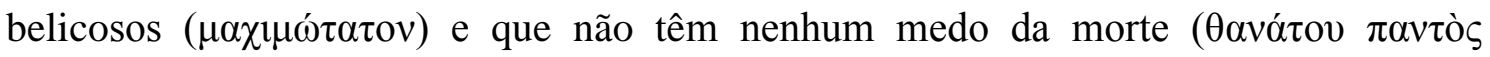
vं $\varepsilon \rho o ́ \pi \tau \alpha$ ). Haynes (2002, p.96), assim, parece-me ter razão ao afirmar que "para muitos dos bandidos dos romances, a violência é o único meio de autoexpressão masculina", ao passo que nos heróis a ênfase é no autocontrole porque eles não esperam ter que encarar conflitos para realizar seus desejos. E se Tíamis declara que os bandidos não devem se preocupar com mulheres e filhos, mas apenas com a sua própria sobrevivência, o herói romanesco só vê sentido em permanecer vivo se a heroína estiver ao seu lado, o que também é motivo para se manter vivo mesmo à custa de não atender expectativas de uma idealização masculina tradicional.

Nesse sentido, a partir do momento em que Tíamis se aproxima da possibilidade de retornar à vida de homem nobre em Mênfis, sua relação com a violência se altera. ${ }^{41}$ Quando ocorre o cerco à cidade, que estava em vias de ser atacada pelos bandidos, Arsace sugere (VII.4.4) que a questão entre os irmãos seja resolvida não com uma guerra, mas com um duelo. Essa situação novamente aproxima Tíamis da representação de um herói épico - a perseguição ao redor das muralhas da cidade é descrita com intenção de aludir a de Aquiles a Heitor ao redor de Tróia (XX.137ss). O episódio também confere uma dimensão trágica a sua intriga e faz lembrar o embate entre Polinices e Etéocles, mas Calasíris surge para acabar com a luta, como um Édipo autoexilado que volta para evitar que os filhos pereçam um pela mão do outro. Da reabilitação de Tíamis, porém, faz parte sua declarada intenção de vencer o duelo, mas não de matar o irmão (VII.5.4), por não desejar poluir suas mãos com o sangue de alguém nascido do mesmo ventre que ele, mostrando-se assim, diferentemente do que havia se visto no livro I, em total controle do uso que pode fazer da violência e capaz de abdicar dela.

\footnotetext{
${ }^{40}$ Sandy, 1982, p.43: "The crone of Bessa serves to link the two halves of the work [...]. This impetus given to the second half of the story by the necromancy at Bessa is Heliodorus' sensational adaptation of the necromancy in book 11 of the Odyssey".

${ }^{41}$ Watanabe (2003, p.17) observa que inicialmente Tíamis não consegue se comunicar com os gregos, mas que a barreira linguística desaparece em Mênfis, quando ele é "gentrificado".
} 


\section{IV.4 Teágenes entre os etíopes: a liderança de Hidaspes}

Da contraposição entre Tíamis e Teágenes e suas atitudes diante de conflitos bélicos decorre uma distinção que marca a violência como meio característico e necessário para o bandido, mas da qual o herói pode - e deve - refrear. O herói também não participa do episódio bélico no livro IX, de modo que Heliodoro deixa o campo de batalha e demais situações envolvidas em uma guerra para representar um ideal masculino centrado principalmente na figura do rei etíope Hidaspes, permitindo a Teágenes demonstrações de sua excelência em outros contextos.

Mais do que qualquer outro protagonista masculino dos romances de amor, Teágenes apresenta a característica essencial do herói de estar "segregado da multidão" (cf. Haynes, 2002, p.83), destacando-se por qualidades relacionadas especialmente a andreia, que possui um aspecto físico muito marcado, notável a partir da mera visão do personagem, mesmo quando ele está à beira da morte (I.2.1). Entre os bandidos, essas qualidades são logo reconhecidas como apropriadas a um homem que pode se tornar um belo acréscimo ao bando. É o que pensa Tíamis, quando o vê ferido na praia, crendo que ele o ajudaria em grandes empresas, se sobrevivesse (I.4.2), e também Traquino, quando aceita atender o pedido de Caricleia de poupar Teágenes e Calasíris: "quanto ao seu irmão, cederei a você com o maior prazer, pois vejo que é um jovem repleto de andreia e capaz de compartilhar nosso tipo de vida" (V.26.3). ${ }^{42}$

A exibição da masculinidade de Teágenes, contudo, acontece de forma mais elaborada em Delfos e em Méroe por meio de suas habilidades atléticas, ainda que Calasíris afirme que, na cidade grega, todo o povo reconhecesse durante a procissão dos

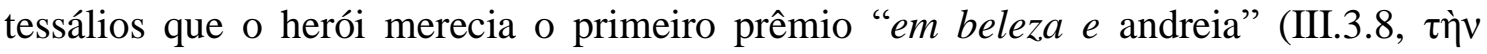

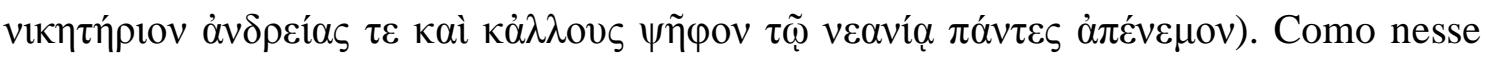
momento aconteciam os jogos na cidade, Teágenes tem oportunidade de dar uma mostra

\footnotetext{
${ }^{42}$ Jones (2012, p.119-122) analisa como a fisiognomia de Teágenes, um assunto de grande interesse no período imperial que acabou tendo grande importância na técnica de caracterização, é indicativa de sua andreia.
} 
do seu valor competindo com um grande campeão, Ormenos da Arcádia, ${ }^{43}$ contra o qual ninguém ainda na ocasião havia se apresentado para competir (IV.2-4). A modalidade não poderia ser mais apropriada para ressaltar a relação entre guerra e atletismo, pois se trata da corrida em que os competidores portavam armadura completa. Calasíris chama a atenção para a chance de Teágenes sair derrotado e sofrer com o peso da desonra ( $\alpha \delta \delta$ o $\left.\mathfrak{i}^{\alpha}\right)$, mas o herói tem uma única motivação nesse momento: receber o prêmio das mãos de Caricleia e impedir que qualquer outro pudesse ter esse privilégio. O povo torce por ele, pois sua beleza garante a simpatia dos espectadores e novamente ele é, segundo Calasíris, semelhante a Aquiles (IV.3.1).

O atletismo continuou sendo uma atividade importante no período imperial. Van Nijf (2003) recentemente argumentou a favor da importância da prática na autoimagem da elite grega do Oriente, contra uma visão até então corrente na qual a guerra e o atletismo seriam pouco relevantes para a constituição da paideia grega na Segunda Sofística, centrada sobretudo em atividades intelectuais. ${ }^{44} \mathrm{~A}$ identidade grega, desse modo, poderia ser construída não apenas por meio da língua e do aprendizado literário, mas também pela dedicação às práticas atléticas. É fato, porém, que circulavam no momento outras teorias, e referências negativas ao treinamento físico são encontrados com frequência nos textos retóricos, ainda que o esforço físico seja apresentado como um dos elementos envolvidos quando os sofistas alegam sua capacidade de exibir e engendrar andreia em seus alunos (cf. Gleason 1995). Van Nijf analisa em especial inscrições do período imperial na Ásia Menor para demonstrar sua hipótese, concluindo que nesse momento o atletismo é entendido como campo essencial para a reafirmação

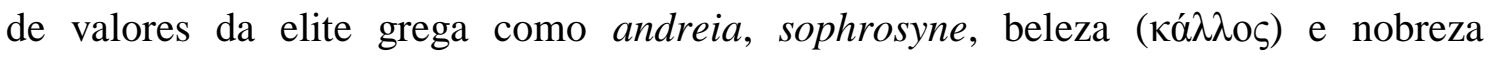

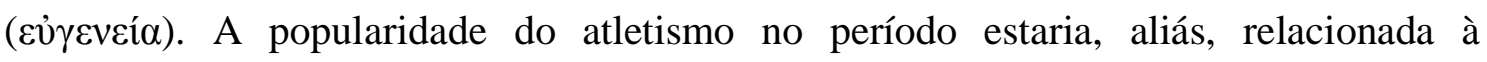
"importância do corpo na expressão de ideais culturais e sociais" (idem, p. 272) e seria evidência do autocontrole do homem público, resultado de seu treinamento físico e

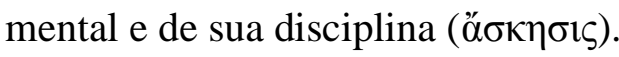

Assim, em um momento em que a elite masculina pouco participava de conflitos bélicos, a competição atlética é o meio privilegiado na construção de ideais de

\footnotetext{
${ }^{43}$ Morgan (in: Reardon, 1989, p.436, n.103) nota que se trata de um nome apropriado para um corredor, por significar literalmente "speeding", mas Bowie (1998, p.6) discorda da tradução e aponta relações interessantes com personagens de mesmo nome em Homero.

${ }^{44}$ A hipótese foi advogada no estudo pioneiro de Gleason (1995). Cf. Connolly (2003).
} 
masculinidade. ${ }^{45}$ Dion Crisóstomo chega a argumentar que ela é superior à atividade militar quando elogia um campeão no pugilato, Melancomas (Or.29.9):

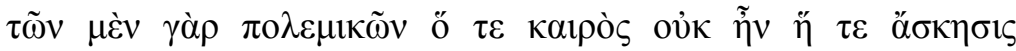

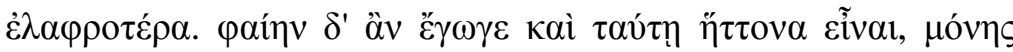

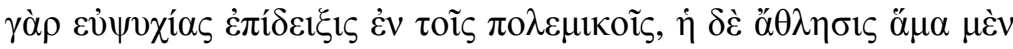

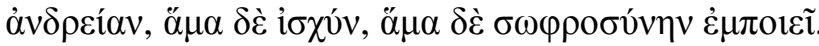

Pois não havia ocasião para atividades militares e, além disso, o treinamento é mais fácil. Eu até seria capaz de afirmar que também nesse aspecto não é inferior, pois há apenas exibição de coragem nas atividades militares, mas o atletismo engendra andreia e ao mesmo tempo força e também sophrosyne.

Que o êxito militar estivesse à altura da vitória atlética nesse momento é fato importante para entender a caracterização de Teágenes em As Etiópicas, pois ele volta a dar demonstração de sua força e habilidade em Méroe, primeiro quando doma um touro sacrificial que havia fugido em disparada diante da visão de uma girafa (X.28-30), depois quando vence um gigante etíope na luta. Não é por acaso que Heliodoro escolhe essa situação com o touro como ocasião em que o herói pode começar a ganhar a simpatia do povo, pois domar o animal era um esporte, praticado especialmente na Tessália no período. ${ }^{46}$ Teágenes persegue-o com um cavalo e, quando o alcança, consegue segurá-lo pelos chifres. O narrador afirma não saber se a atitude de Teágenes

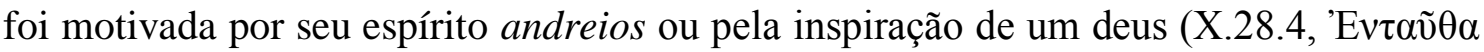

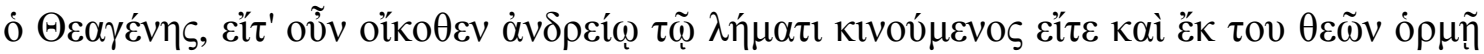
$\chi \rho \eta \sigma \alpha ́ \mu \varepsilon v o \varsigma)$. Logo depois de ser ovacionado pela multidão, sorrindo como em um convite para a celebração, o povo começa a pedir que ele seja posto para enfrentar o gigante etíope, uma sugestão com a qual ele concorda. Como seu oponente em Delfos, o gigante é arrogante e considerado invencível (X.30). Quando Hidaspes informa que a disputa será uma luta ( $\pi \alpha ́ \lambda \eta)$, Teágenes pede que seja um duelo armado com espadas,

\footnotetext{
${ }^{45} \mathrm{O}$ diálogo Anacársis de Luciano (em que o filosofo cita debate com Sólon) é uma peça importante na discussão sobre o valor cultural do atletismo na Segunda Sofística (cf. Goldhill, 2002, p.60-106), bem como o tratado Gymnastikos de Filóstrato. Jones faz apresentação sucinta da questão e discute o caso de Teágenes (2012, p.97ss).

${ }^{46}$ Cf. Morgan (1979, p.436s).
} 
desejando aumentar o perigo para provocar alguma reação em Caricleia, que até o momento não havia tido coragem de falar aos pais sobre a verdadeira natureza de sua relação (X.31.1), mas Hidaspes não o permite.

Com o início da luta, Teágenes leva um primeiro golpe no pescoço. É nesse momento que o narrador informa que ele havia passado a vida toda no ginásio,

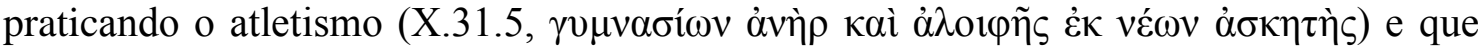
percebera que o melhor era não encarar o gigante, mas superar sua força bruta por meio

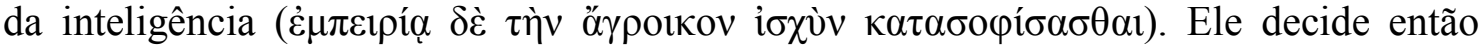
fingir que cai por causa de um segundo golpe, momento em que o gigante se torna confiante da vitória e é surpreendido ao se aproximar do seu oponente, permitindo então que o herói reverta a situação e ganhe a luta.

A vitória de Teágenes sobre o etíope depende de forma evidente do seu treinamento atlético que, por sua vez, lhe permite usar a astúcia para vencer. Se o herói é descendente de Aquiles e comparado a ele mais de uma vez no romance, por outro lado, Teágenes também tem uma marca no corpo que o identifica com Odisseu. Quando está combinando com Caricleia os sinais que possam ajudar no reconhecimento de um e do outro caso eles estejam disfarçados, ele lhe mostra uma cicatriz que carrega no joelho por ter se machucado na caça a um javali (V.5.2). E o personagem já havia dado mostra de sua natureza astuciosa antes: embora Caricleia e Calasíris sejam mais clara e frequentemente relacionados a Odisseu, a ideia de usar um disfarce de mendigo, plano que os dois acabam de fato pondo em prática quando saem da casa de Nausicles em direção à Mênfis (IV.9-10), é primeiramente de Teágenes (II.19.1). Quando o herói sugere essa estratégia, porém, Cnemon zomba da ideia por causa da sua aparência, dizendo que, como mendigos, ele e Caricleia pediriam espadas e caldeirões, em uma referência ao trecho da Odisseia (xvii.222) ele em que se diz que Odisseu, disfarçado, só mendiga restos e não "espadas e caldeirões", presentes apropriados a um nobre. De fato, o uso da inteligência na luta contra o gigante, está "claramente contextualizada em uma tradição de confrontos entre a astúcia grega e a força bruta dos bárbaros, que remonta ao encontro de Odisseu com Polifemo" (Morgan, 1998, p.62), caracterizando a primeira como superior. A combinação de uso da força e de inteligência é vista também na representação de Hidaspes frente ao exército na vitória contra os persas, como se discutirá na sequência.

É comum, talvez, que o leitor perceba no último livro do romance algo que Jones (2012, p.92-93) apontou: 
A natureza espetacular e de última hora desses atos de andreia implica uma consciência da parte dos autores [Cáriton e Heliodoro] de que a expectativa de algum elemento de masculinidade não havia sido atendida até esse momento na conduta de seus heróis.

Ainda que não negue que a aristeia de Teágenes no livro X pareça ter como função dar-lhe alguma dignidade antes do fim da narrativa, creio que a escolha de Heliodoro pode ser plenamente justificada pela situação ímpar em que seu herói se encontra. Teágenes parte da Tessália para Delfos e dali para Etiópia para possivelmente nunca mais retornar à Grécia, ao passo que os heróis de outros romances reassumem seu lugar devido na sociedade da qual são temporariamente afastados. No romance de Cáriton de Afrodísias, a excelência militar de Quéreas, por exemplo, ganha mais sentido se contraposta a de seu sogro Hermócrates e se vista como prova para a cidade de Siracusa de que ela escolheu seu melhor cidadão para desposar Calírroe. Sendo obra dos deuses o fato de que Caricleia e Teágenes chegam à Etiópia como os primeiros prisioneiros de guerra e vítimas sacrificiais, a fim de que o sacrifício humano fosse abolido do país, a sua participação como herói militar lutando ao lado dos etíopes não é possível.

Entretanto, nas duas cidades de Caricleia (Delfos e Méroe), nas quais ela ocupa posição social importante, mas aonde ele chega como um desconhecido, Teágenes deve dar prova de seu valor. Nesse sentido, a vitória nos jogos em Delfos inscreve-o na memória da cidade como um homem célebre que fez algo mais além de ter raptado a sacerdotisa de Ártemis (e a mulher mais bonita de todas). É a "marca" que o herói deixa na sua nativa Grécia, para onde não retornará. "A vitória atlética era uma das fontes mais comuns de kleos - a militar era outra, menos relevante no período" (Van Nijf, 2003, p.270). Esse descendente de Aquiles encontra, assim, outra forma de ser glorificado.

Diante do povo etíope, por outro lado, feliz porque o casal real havia reencontrado uma filha julgada perdida, sua posição como marido da futura rainha deve ser justificada por algo mais além dos sentimentos de Caricleia - para quem rapidamente Hidaspes encontra um pretendente na figura de seu sobrinho Meroebos. Assim, a força e a astúcia exibidas por Teágenes no livro final de As Etiópicas, antes de 
ser um cumprimento à expectativa do leitor na representação do herói, são uma exigência da audiência interna do romance, que deve a partir delas percebê-lo como candidato adequado a assumir funções de homem público como chefe do país. Na impossibilidade de isso ser provado por meio de feitos militares, a demonstração de habilidade atlética é a segunda melhor opção. Em Heliodoro, talvez seja mesmo a primeira, pois ela pode acontecer diante dos olhos do povo etíope, que tudo observa como audiência de um espetáculo.

Hidaspes, por sua vez, precisa mostrar para o leitor que é líder capaz e governante de uma sociedade onde Caricleia pode ser feliz. E depois da heroína ter tido um pai adotivo grego e uma figura paterna no ambíguo Calasíris, Hidaspes surge para assumir a posição daquele em quem o herói deve se espelhar, como são Hermócrates para Quéreas na obra de Cáriton, e, de certa forma, Filetas e o deus Pã para Dáfnis no romance de Longo. Até então Calasíris havia dominado a primeira parte da narrativa, sendo, contudo, uma figura bastante ambígua, uma mistura de homem santo, sábio e mestre na arte de ludibriar as pessoas. ${ }^{47}$ Ao deixar a Grécia, os personagens encontram um percurso penoso entre egípcios e persas e, nesse sentido, o longo episódio bélico do livro IX tem como função estabelecer uma espécie de retorno à civilização, garantido pela ética do rei etíope mesmo em um conflito que é necessariamente violento, que é enfatizada pela comparação com a prática guerreira dos bandidos.

Não que o leitor familiarizado com a tradição literária não tivesse conhecimento do caráter utópico presente muitas vezes na descrição da Etiópia e realmente pudesse temer o retorno de Caricleia a uma sociedade bárbara e ímpia. Trata-se de um país de contornos míticos que acabou sendo posteriormente localizado geográfica e culturalmente. ${ }^{48}$ Os etíopes são caracterizados por Homero como homens justos e longínquos, "os últimos homens" da terra, que vivem no Oceano e, embora Menelau afirme tê-los visitado (iv.84), em outros trechos o país dos Etíopes parece distante a ponto de ser acessível apenas aos deuses. ${ }^{49}$ De início, a Etiópia foi tradicionalmente identificada com o Oriente, mas com o melhor conhecimento geográfico dos gregos, sua localização se alterou para a região subsaariana, onde viviam os povos de cor negra. Em Heródoto, os etíopes são, como em Homero, caracterizados como um povo feliz

\footnotetext{
${ }^{47}$ Sobre a caracterização de Calasiíris, cf. Sandy (1982), Winkler (1982) e Futre Pinheiro (1991).

${ }^{48}$ Cf. Romm (1994, p.45-60). Sobre a representação da Etiópia em Heliodoro, cf. Lonis (1992).

${ }^{49}$ Cf. Ilíada, I.424-5; XXIII.205ss; Odisseia, i.22ss, iv.84.
} 
(III.20ss). O historiador relata um encontro dos etíopes com ictiófagos, enviados até eles pelos persas. Nesse encontro, bem analisado por Romm como sátira (1994, p.54ss), os etíopes desdenham de todos os presentes enviados por Cambises, que planejava invadir seu país - uma túnica púrpura, joias de ouro e mirra -, fazendo uma única exceção ao vinho. Todos os presentes, bem como o alimento principal dos persas, o pão, são rejeitados pelos etíopes como produtos artificiais e desnecessários. A riqueza é representada como algo relativo quando se descobre que os prisioneiros etíopes eram presos com correntes de ouro, um fato que não passa despercebido em As Etiópicas (IX.2) ${ }^{50}$ No romance, todas as características do país remontam à tradição literária e não a fontes religiosas contemporâneas ao autor. ${ }^{51}$

No que diz respeito à caracterização de Hidaspes, mais do que a habilidade militar, Heliodoro favorece a sua inteligência, generosidade e a escolha da diplomacia sempre que possível em detrimento da violência. Nessa contraposição, sua andreia é representada como um aspecto que é suavizado ou harmonizado por um lado philanthropos, que também é uma característica essencial do protagonista da Ciropédia, de Xenofonte, e elemento importante da conduta dos reis helenísticos. Morgan em seu comentário aos livros IX e X (1979), porém, em diversos momentos argumenta contra uma relação de influência direta entre Xenofonte e os historiadores de Alexandre e o romance de Heliodoro na caracterização do rei etíope. ${ }^{52}$ Ele conclui que (idem, p.261s) Hidaspes é muito próximo de um personagem ideal, mas que a maior parte das características envolvidas é tão básica e obviamente desejável e necessária em um monarca competente que não seria possível estabelecer uma dependência do romancista de qualquer autor precedente: "o máximo que podemos dizer é que eles compartilhavam certas correntes de pensamento".

No entanto, é possível estabelecer que a tradição do "monarca ideal” tem início com a Ciropédia, a ponto de a relação entre o texto de Xenofonte e os acontecimentos posteriores à conquista de Alexandre e o subsequente domínio de dinastias pelos três

\footnotetext{
${ }^{50}$ Quando Cambises decide invadir a Etiópia, seu exército inicia uma marcha que parece infindável; ele fica sem provisões e a situação vai se degradando até que os soldados são obrigados a cometer canibalismo; Cambises então desiste do ataque. De fato, ainda que tenham recebido os Ictiófagos, os Etíopes de novo parecem ser "os últimos homens" da terra, inalcançáveis.

${ }^{51}$ Cf. Morgan, 1979. No período imperial, Morgan cita a seguinte lista de menções à tradicional piedade etíope: Estácio, Teb., 5.426ss, Luciano. Jup. Trag. 37, Promet.17, de Sacr.2.

${ }^{52}$ Cf. Morgan (1979, p. 18, p.111 e p.185).
} 
séculos seguintes no Mediterrâneo oriental ser vista como um tanto profética. Não se trata, como observa Farber (1987), de como os reis de fato se comportaram, mas de quais características se considerava desejável ressaltar em sua representação. ${ }^{53} \mathrm{E}$ aquelas que Heliodoro parece ter intenção de enfatizar em Hidaspes podem ser identificadas no Ciro de Xenofonte e nos relatos sobre Alexandre. O romancista, no entanto, parece possuir uma relação crítica com a extrema idealização de líderes políticos; em uma passagem do livro IX (22.7), há possivelmente a intenção do autor de distinguir seu personagem de reis helenísticos, quando o povo de Siene o chama de "seu

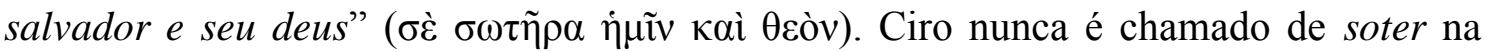
Ciropédia, mas os reis helenísticos com frequência recebiam o título, associado também a um culto. ${ }^{54}$ Hidaspes reage mal ao que dizem os egípcios e observa que o comentário é quase uma ofensa aos deuses.

O próprio estratagema complexo de desviar o rio Nilo e isolar a cidade de Siene, transformando-a em uma ilha, é apresentado como uma solução para tomar a cidade sem que um longo e exaustivo cerco se fizesse necessário, um estratagema que não possibilitaria nenhuma fuga, provocando ao mesmo tempo o menor número de baixas possível (IX.2.3). Webb (2009, p.182) observou que a maneira como é descrita a realização desse feito revela "o caráter e os modos (tropoi)" daquele que a empreendeu, enfatizando-se a medida e a ordem na disposição dos soldados durante a obra. A eficiência do plano prova ser Hidaspes um estrategista brilhante e sua preocupação em evitar mortes será novamente enfatizada, dessa vez também com relação aos vencidos. A situação ocorre logo após a rendição da cidade de Siene, quando Oroodantes solicita que Hidaspes permita que dois persas sejam enviados a Elefantina (IX.6-7) a fim de consultar as tropas ali reunidas com relação à rendição, afirmando ainda que não aceitaria ser acusado de traição pelo rei persa e que a morte em guerra contra os etíopes lhe seria mais suave do que uma morte imposta como punição pelo grande rei. Hidaspes considera a atitude de Oroodantes tola (IX.7.2, $\pi \mathrm{o} \lambda \lambda \dot{\alpha} \tau \tilde{\eta} \varsigma \dot{\alpha} \beta \varepsilon \lambda \tau \eta \rho i ́ \alpha \varsigma)$, porque o persa julga poder falar em pé de igualdade com ele, mas acaba cedendo ao pedido ao pensar nos muitos homens que poderiam morrer em resultado da atitude do sátrapa. A decisão

\footnotetext{
${ }^{53}$ Não chegou ao meu conhecimento nenhum estudo que investigasse até que ponto foi relevante a influência da Ciropédia no pensamento político do período helenístico, mas Farber (1987) enumera paralelos entre valores apresentados de modo positivo no texto de Xenofonte e na representação de monarcas do período.

${ }^{54}$ Cf. Farber (idem, p.510s).
} 
de Hidaspes não apenas demonstra sua grandiosidade, mas vai permitir um contraataque persa, que, por sua vez, possibilitará ao rei etíope a demonstração de sua superioridade também em campo de batalha. ${ }^{55}$

Quando o sátrapa e os demais persas conseguem sair da cidade despercebidos, enquanto os egípcios se ocupavam do festival religioso em honra ao rio Nilo, a cidade de Siene desespera-se e passa a temer uma represália da parte dos etíopes (IX.11), apesar de já ter ciência da magnanimidade de Hidaspes (X.11.3, $\varphi \imath \lambda \alpha v \theta \rho \omega \pi i ́ \alpha$ ). Eles decidem sair da cidade e apelar à compaixão do exército, carregando ramos de árvores e tochas como sinais de súplica, além de imagens de deuses e bandeiras de paz. Um último gesto de desespero é soltar crianças pequenas no chão que, assustadas com os gritos de seus pais, afastam-se deles e engatinham em direção ao suposto inimigo. Exagerada e incongruente que a cena possa ser, ${ }^{56}$ criando um suspense irreal, ${ }^{57}$ uma vez que o leitor já havia tido provas do caráter de Hidaspes, sua atitude é focalizada pelo povo egípcio, de modo que ela tanto enfatiza quão singular ela deve ser considerada quanto a contrapõe à liderança violenta e cruel dos persas.

O que se segue, então, é uma grandiosa batalha entre os dois exércitos (IX.1420), comparável à de Thimbrara no livro VII da Ciropédia: “Ambas são batalhas climáticas inseridas no fim da narrativa que incluem cavalaria, elefantes, carros citas e uma verdadeira ONU de aliados" (Hilton, 2005, p.77). No entanto, já se demonstrou que a variedade de fontes do episódio é muito maior; a batalha é totalmente construída com elementos retirados da tradição literária e narrada com técnicas empregadas na historiografia, a fim de garantir realismo à cena. ${ }^{58} \mathrm{~A}$ vitória dos etíopes permite que Hidaspes dê outra série de demonstrações do seu caráter magnânimo. Oroodantes, quando vê que seu exército será vencido, como Dario na Batalha de Gaugamela, foge, abandonando seu carro e montando sobre um cavalo. ${ }^{59}$ Ao persa, será permitida uma

\footnotetext{
${ }^{55}$ Sua atitude faz lembrar a de Alexandre após a vitória na Batalha de Isso (333 a.C.), segundo o relato de Arriano: por carta, o macedônio recrimina Dario por pretender lhe fazer exigências (a de liberar sua família), embora afirme que cederá aos seus pedidos (Anab.2.14.9).

${ }^{56}$ Cf. Hilton (2005, p.76s).

${ }^{57}$ Cf. Morgan (1979, p.102).

${ }^{58}$ Cf. o comentário detalhado de Morgan (1979) e seu artigo de 1982.

${ }^{59}$ Morgan, que em geral é contrário à presença de alusões diretas no episódio, argumenta que o modelo aqui de fato é Dario (Plutarc, Alex.33.8, Arriano, Anab.3.14.4-5) porque em ambos os casos parte do exército continua a lutar sem perceber a fuga do seu líder.
} 
reabilitação mais adiante, pois ele é capturado vivo por um dos soldados etíopes que impede que ele seja morto por Aquemenes. Ao ver aquilo que ele acredita ser a tentativa de aproveitar a ocasião para resolver uma rixa pessoal, o soldado considera a atitude odiosa e salva o sátrapa matando Aquemenes (IX.20.5s).

O ressurgimento de Aquemenes na história é uma prova da habilidade com que Heliodoro controla as diversas tramas da narrativa. Ele tinha sido visto pela última vez atiçando Oroodantes contra sua esposa Arsace e persuadindo-o a trazer a Siene Teágenes e Caricleia (VIII.1-2), pois acreditava que se o sátrapa a tomasse como sua concubina, logo também ele teria oportunidade de se apossar de Caricleia. Sua história ainda não havia sido concluída e o narrador expõe sua motivação para atacar Oroodantes dizendo que ele se arrependia da acusação que fizera contra Arsace, uma vez que ela havia se suicidado e não havia mais como dar provas das suas alegações, de modo que ele poderia ser julgado responsável pela morte da esposa do sátrapa. Ao soldado comum que salva Oroodantes é dado como prêmio o cinto cravejado de pedras no qual Oroodantes carregava sua espada (IX.23). Novamente a atitude de Hidaspes é focalizada pelos personagens, dessa vez outros soldados etíopes, que consideram o prêmio valioso demais para um homem comum (o que contradiz a informação que vem logo na sequência de que ouro e pedras preciosas são abundantes na Etiópia, cf. IX.24.1).

Nesse caso em particular, o resultado foi incongruente; porém, com frequência a técnica empregada pelo autor de apresentar os fatos a partir de pontos de vistas diversos tem resultados menos incoerentes e mais relevantes para a narrativa. Esse é o caso com Oroodantes; questionado por Hidaspes a respeito de seus motivos para mostrar-se desleal, o persa responde que seu ato fora, na verdade, uma demonstração de sua

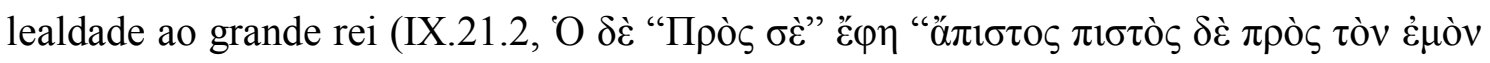
$\delta \varepsilon \sigma \pi$ ó $\eta v ")$. Hidaspes é convencido que a traição a sua confiança fora, na verdade, justificada, mas observa que era incompreensível que ele tivesse se disposto a lutar contra um número muito maior de homens, ao que o persa responde que sua atitude pode ser entendida a partir do ponto de vista do Grande Rei, que é pior em punir os

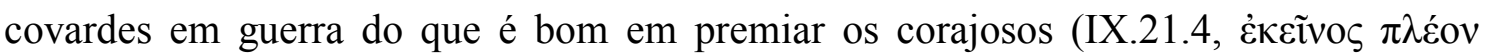

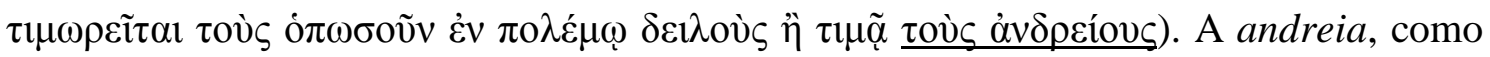
concebida pelos persas, é assim representada como uma exigência moral de enfrentar o inimigo a qualquer custo, acima da preservação da vida, havendo uma recusa de saídas diplomáticas que poderiam evitar inúmeras mortes, como queria inicialmente o rei 
etíope. É possível que isso atenda a uma visão mais tradicional da heroicidade guerreira, mas o comportamento de Oroodantes é visto de uma forma no mínimo ambígua, senão claramente negativa.

A própria natureza da guerra pela posse de minas de esmeralda é concebida de forma tal que a Etiópia não seja considerada nem agressora nem detentora de interesses imperialistas, sugerindo-se que o país se volta para a guerra apenas por necessidade. É por causa das minas que Sisimitres havia se dirigido ao Egito, na ocasião em que entrega Caricleia ao seu pai adotivo grego, o que sugere que a questão estava em debate havia cerca de dez anos, ${ }^{60}$ mas Hidaspes no seu discurso final ao sátrapa persa, dirá que essa única vitória lhe basta (IX.26.2):

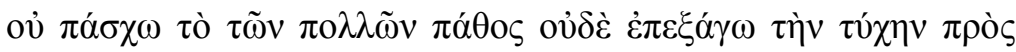

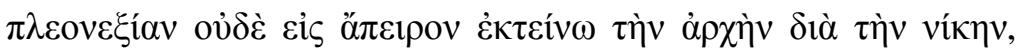

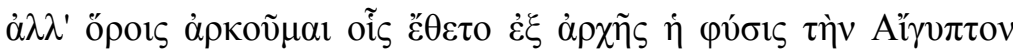

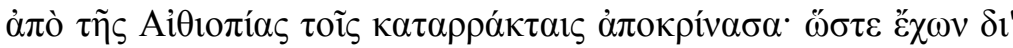

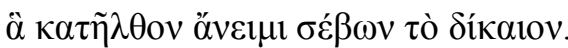

Não padeço do mal comum de querer abusar da sorte por causa da ambição ou estender meu governo até o infinito por causa desta vitória, mas me satisfaço com os limites que a natureza havia imposto desde o início entre o Egito e a Etiópia, separandoos pelas cataratas. De modo que, de posse daquilo que vim buscar, eu parto respeitando o que é justo.

Hidaspes fala da guerra como se ela não tivesse ocorrido por questões comerciais, mas para ver obedecida a vontade da natureza. Nesse aspecto, ele mais uma vez lembra o retrato que Xenofonte faz de Ciro: Due (1989, p.158ss) nota que na Ciropédia entende-se que atacar outro país é algo moralmente errado e que o filósofo faz um relato diferente do de Heródoto da campanha de Creso para enfatizar essa visão,

\footnotetext{
${ }^{60}$ Há uma referência em Teofrasto (De lapid.34) a minas de pedras preciosas perto de Siene, mas é pouco provável que fossem de esmeraldas. Havia minas de esmeralda mais ao leste do Nilo, em uma região chamada de Smaragdus Mons. No século III d.C. elas foram tomadas pelos Blêmios, de modo que a disputa por essas minas podem ter chamado a atenção, o que justificaria sua inserção no romance. Cf. Morgan (1979, p.61).
} 
colocando a Pérsia em uma posição mais defensiva. ${ }^{61}$ Ao continuar o seu discurso, Hidaspes pede a Oroodantes que, caso a ele seja permitido continuar vivo, que diga ao grande rei que fora vencido pelas armas, mas que o rei etíope havia lhe permitido manter tudo o que era seu e que agora ele desejava ter relações de amizade, embora não fosse fugir da luta se ela se mostrasse necessária.

Na permissão de deixar seu inimigo vivo e com ele tentar estabelecer um elo de amizade, entra em cena novamente a philanthropia do rei etíope que, como outras das suas características como líder, tem antecedentes tanto na Ciropédia, em que talvez ela seja o traço por excelência de Ciro, quanto em Alexandre. É curioso observar em Heliodoro a relação entre andreia e philanthropia na fala dos emissários de Hidaspes quando se dirigem aos rendidos persas e egípcios (IX.6.2): eles afirmam que o rei sabe

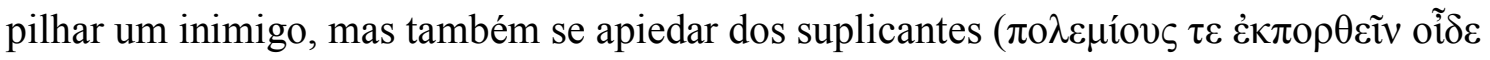

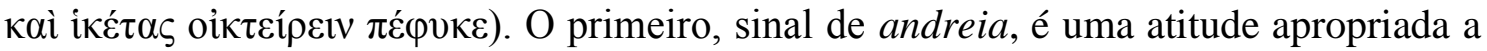
um soldado, o segundo, evidência de philanthropia, algo que é mais próprio da sua disposição natural. A andreia, portanto, não significa aqui apenas "coragem" ou "masculinidade", mas é um traço construído culturalmente e desejável que, por outro lado, torna o homem também propenso a violências que não precisam ser praticadas (mas que em geral o são) como exibição da própria andreia. O valor que distingue um grande líder é, dessa forma, sua consideração pelo outro. Hidaspes deixa então que os persas decidam quais serão os termos de sua rendição, desejando, com isso, respeitar os deuses ao não se mostrar tirânico.

Morgan (1979, p.237) afirma não acreditar que essa atitude do personagem tenha como modelo Alexandre; para o crítico, no caso do general macedônio, a permissão dada aos vencidos de manterem seus cargos diz respeito a uma conveniência administrativa na criação de um império, ao passo que em Hidaspes se trata de mera benevolência. No entanto, Xenofonte havia deixado claro na caracterização de seu Ciro que a exibição de philanthropia não é algo gratuito, mas da qual se espera uma compensação, sendo, na verdade, uma prova de inteligência política. Ciro calcula quando demonstrar sua generosidade, a fim de tornar seus novos súditos leais e garantir a sua própria segurança. ${ }^{62}$ Nesse sentido, a contraposição feita no discurso dos

\footnotetext{
${ }^{61}$ Contra, cf. Gera (1993, p.183ss).

${ }^{62}$ Por exemplo, Ciropédia, 5.1.26, 8.2.1, 8.7.13. Cf. Farber (1987, p.509ss), Tatum (1989b, p.199ss).
} 
emissários etíopes encontra um paralelo em uma passagem da Ciropédia (8.4.7), ${ }^{63} \mathrm{em}$ que a philanthropia é avaliada em relação à strategía, o comando militar. ${ }^{64}$ Quando a Gobrias é permitida a permanência no seu cargo, ele observa que Ciro tem ainda mais a primeira do que a segunda, ao que o persa responde que a generosidade causa muito mais prazer do que a habilidade militar, pois naquela necessariamente se faz mal aos homens e, nesta, o bem. E é por ter essa qualidade-chave que Ciro se torna um grande líder, ao fazer com que as pessoas obedeçam ao seu comando voluntariamente.

Jones (2012, p.149ss) analisa a forma como a philanthropia de Hidaspes é apresentada como algo natural (IX.6.2, $\pi \varepsilon ́ \varphi v \kappa \varepsilon)$, e não como uma resposta à súplica de seus inimigos, algo que ajudaria a caracterizá-lo como homem pepaideumenos, uma vez que é assim que esse valor é mais frequentemente representado na Segunda Sofística, ou seja, como uma noção grega que deve ser aprendida em um processo de helenização. Assim, é a andreia de Hidaspes, que se torna o outro lado da moeda do que é natural, devendo ser vista como algo a ser construído na personalidade de um homem e exibido em atuação militar. Isso é ressaltado no último livro (X.16.2): quando ele é finalmente convencido de que Caricleia é sua filha, o narrador comenta que Hidaspes fica dividido

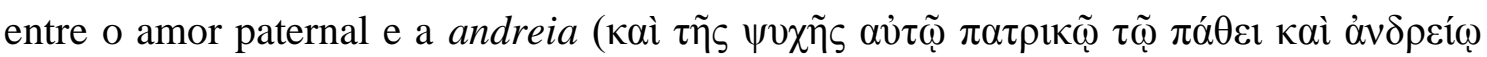

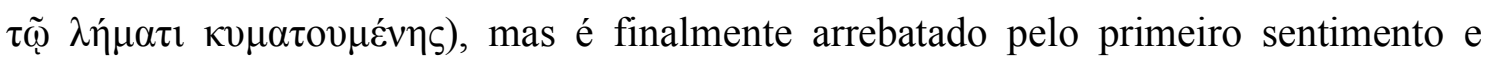

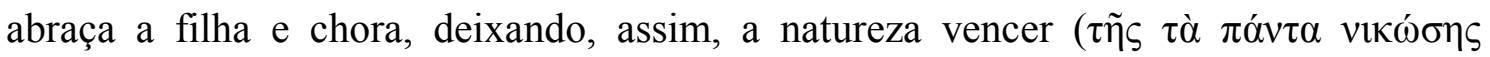

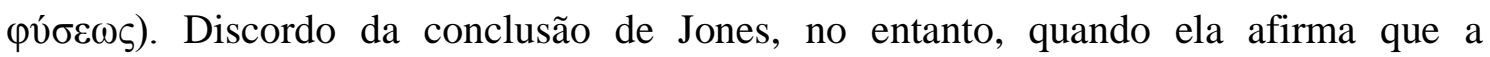
philanthropia de Hidaspes tem apenas aparência de algo inato, considerando que a helenização do personagem é tão bem-sucedida que "ele é capaz de aplicar ao seu comportamento padrões de helenismo obtidos pelo aprendizado de forma tão perfeita que eles parecem naturais" (idem, p.151). Essa observação parece apenas atender a um desejo de ver conformidade na caracterização de Hidaspes com o do homem culto da Segunda Sofística, não havendo com isso, porém, nenhum ganho para a compreensão do personagem. Parece-me que o mais importante a frisar é que na representação do rei etíope, a andreia só é totalmente positiva quando harmonizada por outras características. E mais: trata-se de características que são naturais, de modo que aquilo que faz um bom líder é algo que, no fim das contas, é inato. É preciso saber, como

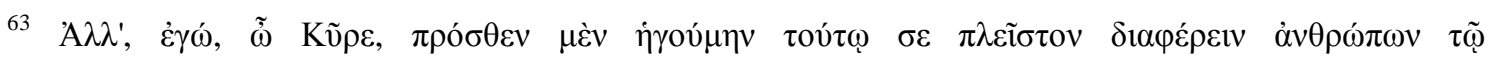

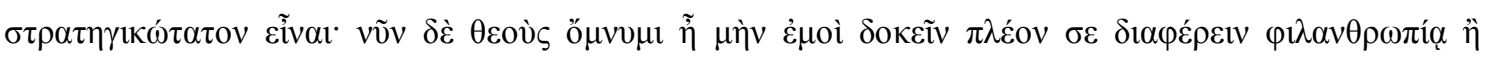
$\sigma \tau \rho \alpha \tau \eta \gamma \dot{\alpha} \alpha$.

${ }^{64}$ Cf. Due, 1989, p.166s.
} 
Hidaspes, quando é aceitável ou mesmo apropriado deixar a andreia de lado em favor de outros valores.

Pela forma como é introduzido na narrativa e pela posição que nela ocupa, o ideal de masculinidade no romance é o rei etíope, a quem Teágenes sucederá no trono. ${ }^{65}$ Se Calasíris é a figura que domina a primeira parte do romance, é porque sua astúcia, identificada de modo explícito com a de Odisseu, e seus meios nem sempre honestos de obter o que quer são necessários duplamente: é apenas pela sua ação dúbia que se pode colocar em movimento o nóstos de Caricleia e é sua inteligência que diversas vezes garante a segurança do casal no mundo não civilizado que encontram ao partir da Grécia. Embora a perseverança no enfrentamento dos males e a astúcia também sejam duas qualidades importantes naquele que exerce o poder, Heliodoro, diferentemente de Cáriton, não dá chance aos seus personagens de mostrar que o amadurecimento ao longo da viagem teve como resultado tornar o casal mais apto a assumir suas funções de

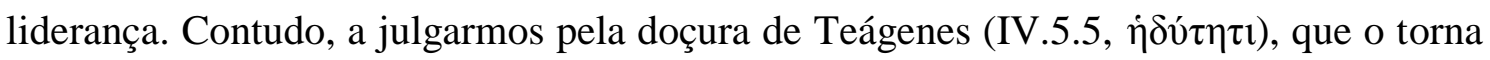
uma versão aprimorada de Aquiles, creio que o leitor pode concluir que ele possui as qualidades necessárias para se tornar um substituto à altura do pai de Caricleia no trono etíope.

\footnotetext{
${ }^{65}$ Cf. Lalanne (2006, p.187).
} 


\section{A Guerra no Romance Grego: Controlando a Violência?}

Embora a ausência de Aquiles Tácio possa ter sido sentida ao longo desta tese, nossas considerações finais começam a se desenhar com esse autor, cuja narrativa é uma joia da Segunda Sofística. Ainda que o episódio bélico da forma como é desenvolvido em Leucipe e Clitofonte não nos pareça lidar com a questão de um ideal de comportamento masculino, é uma guerra, travada entre Bizâncio e a Trácia, que permite o encontro do par romântico. Sóstrato, pai de Leucipe, que tinha na guerra um papel de liderança, decide enviar esposa e filha para Tiro, cidade onde vivia seu irmão, o pai de Clitofonte. Além disso, o desempenho exemplar em guerra, na qual chega à posição de general, é um dos principais fatores que possibilita ao personagem Calístenes redimir-se do crime de ter raptado Calígone, a irmã de Clitofonte, e ser recebido pela família como digno de sua mão (VIII.17.9-10). Ambos os fatos demonstram que, no pano de fundo do romance, a atuação dos homens na guerra é algo esperado e necessário e que o valor marcial é um importante aspecto na avaliação do caráter de um homem. O problema é que o episódio bélico propriamente dito, da forma como é narrado em primeira pessoa por Clitofonte, ressalta a sua própria falta de qualidades heroicas e ganha função mais de espetáculo - no qual o herói-sofista pode esbanjar sua habilidade retórica - do que de um evento que possibilita o desenvolvimento de questões éticas que envolvam o papel social masculino.

É notório que Aquiles Tácio brinca com os limites do romance de amor, a começar pelo fato de que o herói seduz a heroína e eles só não consumam o sexo antes do casamento por causa do sonho que alerta a mãe de Leucipe e faz com que ela entre no quarto da filha na hora H (II.23). Clitofonte, além disso, deixa claro que já havia tido experiências sexuais com prostitutas (II.37), o que lhe permite até entrar em uma discussão acalorada a respeito dos prazeres específicos dos amores hetero e homossexual. Adiante na narrativa, ele não consegue resistir aos avanços de Melite, mesmo sabendo que tanto o marido dela quanto Leucipe estavam vivos, ao contrário do 
que a princípio eles imaginavam, e depois de praticarem sexo em uma cela de prisão em Éfeso (V.27), Clitofonte escapa de lá vestido com as roupas de Melite, em um travestismo tão convincente que é capaz de enganar o guarda (VI.1-2). Ainda mais divertido é o fato de que ela só escapa da punição pelo adultério porque jura que não traiu o marido, Tersandro, quando ele estava desaparecido (VIII.11.3) - sem faltar com a verdade, porque a traição ocorre quando ele já havia retornado à cidade. ${ }^{1}$

Em se tratando da guerra, se tomarmos como ponto de comparação o desenvolvimento dado ao tema por Cáriton, o herói-narrador é uma decepção. Lalanne (2006, p.168-174), aliás, observa que ele falha em todos os testes que lhe são impostos: o da guerra, o da fidelidade e o da capacidade de rivalizar com outro homem na luta e pelas palavras. Logo depois que Leucipe e Clitofonte se tornam prisioneiros dos boukoloi, os bandidos declaram sua intenção de sacrificar uma virgem aos deuses; Leucipe é levada por eles, sem que Clitofonte esboce qualquer tentativa de impedi-los. ${ }^{2}$ Imediatamente depois ele encontra uma oportunidade de escapar e não a desperdiça: deparando-se com um regimento de cinquenta soldados (III.13) e percebendo que os

\footnotetext{
${ }^{1}$ A leitura do romance de Aquiles Tácio como paródia foi sugerida pela primeira vez por Durnham (1938), que advogava, porém, que Heliodoro era o modelo subvertido na narrativa, uma hipótese que se revelou infundada quando se mostrou que este autor era posterior àquele. Apenas recentemente Chew (2000) retomou a ideia, sugerindo que em Leucipe e Clitofonte a paródia limita-se à moral convencional do romance, em particular à representação da sophrosyne, uma vez que, no fim das contas, as convenções mais importantes do gênero são observadas, como a castidade da heroína e o casamento. Contudo, Chew nota que (2000, p.63): "Both Clitophon and Leucippe have dreams in which gods instruct them to be chaste (4.1). That is, their sexual restraint comes not from a personal belief in the principle of chastity but is imposed upon them from the outside; that chastity does not come naturally to them is unique among novels".

2 É a partir desse encontro com os bandidos que o episódio bélico de Leucipe e Clitofonte é desenvolvido nos livros terceiro e quarto. Os boukoloi são atacados por uma infantaria de cinquenta hoplitas e Clitofonte consegue escapar na direção dos soldados. Depois da primeira batalha, o ataque da infantaria é impedido por uma grande trincheira construída para proteger o campo dos bandidos. Quando os soldados finalmente conseguem dar conta desse obstáculo, o general anuncia um atraso na chegada dos reforços que vinham de Heliópolis para auxiliá-los no ataque contra a força principal dos boukoloi. Há, então, uma pausa nos preparativos para o combate, durante o qual são narrados outros acontecimentos envolvendo Leucipe e Clitofonte, até que o sátrapa do Egito envia uma mensagem ordenando o ataque imediato. Os soldados assumem suas posições, mas os boukoloi os enganam enviando anciãos para propor um acordo e, com isso, a formação é desfeita. Os soldados caem então em uma emboscada e são derrotados, mas, em seguida, uma força maior chega para socorrê-los e os bandidos são finalmente sobrepujados.
} 
bandidos levavam a pior no confronto, todos os prisioneiros dos boukoloi fogem. Então, levado à presença do general Cármides, que promete lhe dar armas e informa sua estratégia para derrotar os bandidos, sugerindo esperar que Clitofonte tome parte do combate ao seu lado, o herói logo demonstra ter tido treinamento adequado para um homem de seu status social (III.14.2):

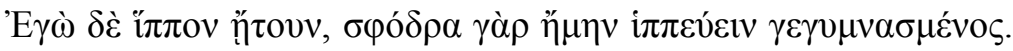

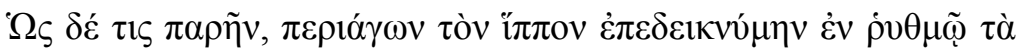

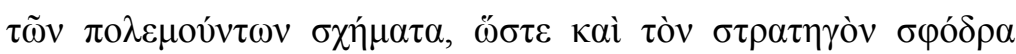

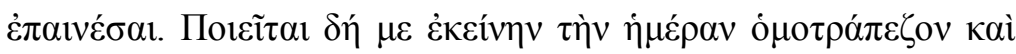

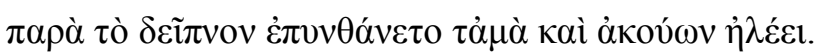

Pedi-lhe um cavalo porque tinha praticado equitação e sabia montar com destreza. Trouxeram-me um e, descrevendo várias voltas, executei, em cadência, uma graciosa demonstração das diferentes figuras de combate equestre, de modo que até o próprio comandante me elogiou efusivamente. Então, nesse dia, convidou-me para sua mesa e, durante o jantar, quis conhecer a minha história, que ouviu compadecido. ${ }^{3}$

A exibição de habilidade garante a Clitofonte acesso privilegiado ao general, mas disso não resulta absolutamente nenhuma ação na guerra travada contra os boukoloi. O herói, porém, não é o único a portar-se de forma inadequada nessa situação. No dia seguinte, Leucipe é sacrificada pelos bandidos (III.15), no primeiro Scheintod da heroína, observada de longe por Clitofonte. Pouco depois, porém, ela aparece viva e o truque teatral utilizado por Menelau e Sátiro, que acompanhavam o casal na viagem, é revelado (III.20-22). Com Leucipe no acampamento, a guerra fica em segundo plano; primeiro é o general Cármides que se apaixona por ela (IV.2) e afirma que em guerra não é possível adiar a satisfação de um desejo ${ }^{4}$ depois, a heroína enlouquece (IV.9) e descobre-se que isso é resultado do fato de ela ter recebido em dose concentrada um filtro de amor preparado por um soldado apaixonado (IV.15). No meio desses

\footnotetext{
${ }^{3}$ Os trechos de Aquiles Tácio citados em português nesta conclusão são da tradução de A. Pena (2005).

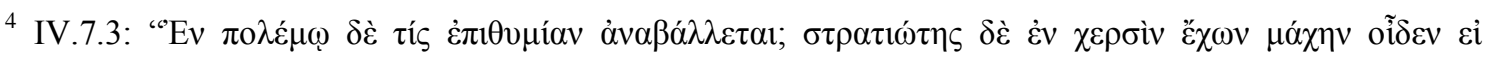

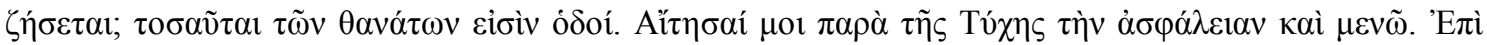

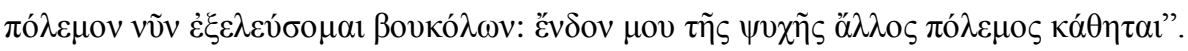


acontecimentos paralelos, a guerra continua a se desenrolar, mas Clitofonte permanece todo o tempo apenas um observador. Ele narra um combate (IV.13-14) que lhe permite fazer também uma digressão acerca do Nilo e uma écfrasis do pântano habitado pelos bandidos, ${ }^{5}$ mas não comenta em absoluto o fato de não se engajar na luta e quase nenhuma atenção dá à batalha final em que os bandidos saem derrotados, ${ }^{6}$ demonstrando que o aspecto espetacular interessa-lhe mais do que a resolução da guerra

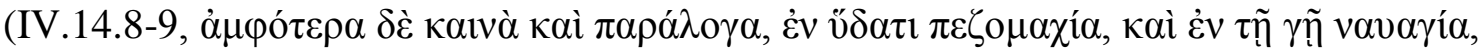
"eram duas coisas inéditas e prodigiosas: na água, um combate de infantaria, em terra, um naufrágio!"). Clitofonte é muito mais sofista e amante do que soldado e adiante na narrativa ainda tomará três surras sem esboçar nenhuma tentativa de defesa. ${ }^{7}$ Não por acaso, o tema da guerra é mais explorado em um desenvolvimento particular da militia amoris por Aquiles Tácio em que o termo andreios e seus cognatos são usados em referência a uma virilidade meramente sexual (Jones, 2012, p.168ss).

A construção de um personagem com tão pouco em comum com os demais heróis do romance grego é uma demonstração exemplar de que as convenções do gênero estavam à disposição dos autores para serem trabalhadas como bem lhes parecesse, o que incluía também a possibilidade de subversão. Embora Lalanne (2006) não seja, de forma alguma, insensível aos aspectos literários dos romances, ela os toma, porém, como documentos históricos. Ler a caracterização de Clitofonte como subversão de ideais de masculinidade propagados pelo gênero romanesco ${ }^{8}$ é algo que não cabe na sua tese de que o romance de amor representa ritos de passagem, de modo que ela defende a hipótese de que o caráter anti-heroico do personagem demonstra que ele hesita em se tornar homem e que o processo de amadurecimento dos rapazes pode ser tão coercitivo quanto é o das mulheres. Parece-me, porém, que, ao passo que alguns romances se adequam bem à estrutura proposta por Lalanne, no caso de Aquiles Tácio é

\footnotetext{
${ }^{5}$ Cf. Panagakos (2004, p.226-234), Bartsch (1989, p.123s).

${ }^{6}$ Narrada em uma frase breve (IV.18.1): “Entretanto, chegou da metrópole uma força mais poderosa que

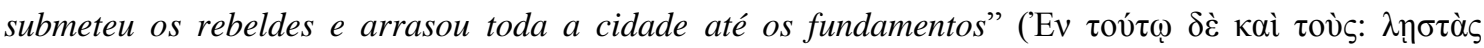

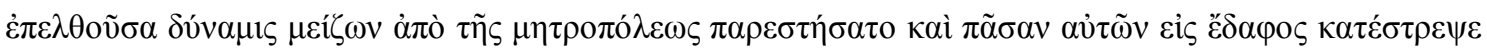

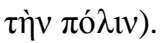

${ }^{7}$ De Tersandro, V.23 e VIII.1 e de Sóstrato, pai de Leucipe, VII.14. Quanto ao fato de Clitofonte suportar de forma passiva o abuso físico, Haynes (2002, p.86) observa que "isso é deliberadamente exagerado até o efeito se tornar grotesco".

${ }^{8}$ Essa é também a posição de Jones (2012, passim).
} 
realmente difícil perceber um processo em que o comportamento do herói vai sendo moldado para atender a expectativas tradicionais a respeito do papel social masculino. Além disso, como narrador das suas próprias aventuras pretéritas, Clitofonte deveria demonstrar mais (ou, pelo menos, alguma) consciência sobre o seu processo de amadurecimento, se de fato ele aprende alguma coisa ao "concluir" seus ritos de passagem e se casar com Leucipe. Pelo contrário, o fato de ele aparecer, no começo do romance, infeliz (e sozinho) em Sidon, ocasião em que encontra alguém para escutar a sua história, faz o leitor questionar o que teria acontecido desde o casamento até aquele momento. A última das subversões de Aquiles Tácio seria não permitir o "felizes para sempre" para o casal de protagonistas? ${ }^{9}$

Além disso, Lalanne argumenta que os homens são treinados nos romances para o combate. Embora me pareça clara a importância que a guerra ainda possui nesse momento como situação de estabelecimento de ideais de masculinidade, mesmo que, como observa autora $(2006, \mathrm{p}, 126)$, os romances tenham sido produzidos ao longo do período conhecido como Pax Romana e as cidades tenham encontrado outras formas de regular os conflitos, é notório que somente Cáriton se vale do triunfo marcial como aspecto que distingue Quéreas, sendo em geral características mais banais (como beleza e nobreza) que destacam os heróis romanescos da multidão de outros homens. Assim, embora possamos perceber, em geral, um amadurecimento dos protagonistas do romance, que começam a narrativa muito jovens, ainda adolescentes, e que depois de uma série de aventuras retornam à sociedade para assumir posições importantes ao final da narrativa, os romances são obras literárias complexas em que podemos perceber diferentes discursos sobre valores culturais. Desse modo, a masculinidade de Clitofonte, se interpretada como paródica, evidencia um jogo literário que não cabe na hipótese da representação de ritos de passagem; se, por outro lado, interpretada como um discurso em que se apresenta outro tipo de identidade masculina, mais próxima da de um "sofista efeminado", ${ }^{10}$ não temos nos romances a uniformidade que Lalanne parece supor no

\footnotetext{
${ }^{9}$ Repath (2005) defende que sim, argumentando que o narrador sugere um “non-happy non-ending” para Leucipe e Clitifonte.

10 Jones (2012, p.267ss), que percebe uma subversão dos valores de masculinidade no personagem, sugere que o fato de ele ser fenício (portanto, não um grego genuíno, mas um "helenizado") permite ao autor lhe dar características que o aproximam do tipo de retor da Segunda Sofística que deliberadamente tomava para si aspectos femininos em estilo retórico e aparência. Não tenho certeza, porém, se o detalhe da origem de Clitofonte faria muita diferença no contexto cultural do século II d.C.
} 
processo de constituição dos gêneros sexuais. A meu ver, Aquiles Tácio lança mão de ambas as estratégias.

Chamar a atenção para o problema de leituras como a de Lalanne, que supõem uma chave interpretativa para o gênero do romance como um todo, é de nosso interesse porque o objetivo desta tese foi, desde o projeto inicial, discutir a temática da guerra nos romances de forma a destacar as funções diferentes que os episódios bélicos assumiam nas narrativas, por oposição a uma visão geral da guerra como apenas "mais uma aventura" pela qual os protagonistas deveriam passar antes de sua (re)união e final feliz. ${ }^{11}$ Uma opinião comum é de que a guerra é com frequência encarada como um tópos obrigatório pelo romancista, que então desenvolveria o tema quase por “obrigação". Espera-se ter demonstrado o contrário, que o tema ganha importância fundamental no estabelecimento de ideais de masculinidade, que são parte importante do enredo do romance de amor. Nossa leitura permitiu, nesse sentido, ambos os movimentos de procurar diferenças e encontrar semelhanças nos discursos dos romancistas no que concerne às características que um homem deveria ser capaz de exibir. É natural que haja certa conformidade entre eles, mas a forma como Aquiles Tácio parece negar a possibilidade de qualquer aprendizagem ou demonstração de heroísmo em guerra (ao menos no que concerne ao personagem masculino principal) serve a uma representação menos idealizada dos personagens e deixa claro que não é possível observar uma identidade uniforme (seja de gênero sexual ou de um suposto "helenismo") ${ }^{12}$ em narrativas tão variadas e complexas como são as que formam o nosso corpus.

Em Cáriton de Afrodísias, que pode ser o modelo primordial do gênero (segundo hipótese de Tilg, 2010) e no qual talvez seja possível observar a constituição da tópica romanesca, a inserção do tema da guerra é justificada pela proximidade que o autor deseja criar entre o romance e a tradição historiográfica grega. No cenário político desenhado como pano de fundo das ações, que envolvem homens de posição preeminente na Sicília e no Império Persa, a disputa por Calírroe como um combate é uma ideia explorada no plano metafórico, indicando que aquele que puder conquistá-la

\footnotetext{
${ }^{11}$ Hilton (2005, p.58): "it is often just one more trial that the young people have to endure before their final and inevitable reunion".

${ }^{12}$ Whitmarsh em seu recente estudo sobre narrativa e identidade no romance grego, criticando a abordagem de Lalanne, observa que (2011, p.44): "romances are not simply socially programmatic; they are complex literary narratives, and narratives [...] can model multiple, competing forms of identity".
} 
é superior a seus pares. A guerra torna-se, então, “o melhor juiz" da disputa (VII.5.15, VIII.4.2). Isso não significa, porém, que a habilidade marcial seja o valor supremo na caracterização do herói, pois os dois principais rivais no amor de Calírroe, Quéreas e Dionísio, têm desempenhos semelhantes, ainda que o grego atue como homem livre e demonstre ser capaz de vencer comandando um número de soldados muito inferior ao de seus inimigos.

A guerra, além disso, não é apenas uma estratégia narratológica que resolve o imbróglio da disputa por Calírroe. Parece-me correta a leitura de que Quéreas é caracterizado de forma negativa na primeira parte do romance. Isso envolve especialmente um descontrole das emoções, perceptível quando, dominado pela raiva, ele desfere um golpe contra a esposa, por acreditar que ela lhe estava sendo infiel. Essa atitude contrasta, por um lado, com a frieza dos ex-pretendentes de Calírroe, capazes de planejar uma estratégia complexa de vingança em razão da raiva que sentiam por Quéreas, e, por outro lado, com a sensatez de Hermócrates, que não se deixa dominar pelo ódio quando o herói "assassina" sua filha nem quando o pirata Téron é desmascarado como raptor de Calírroe. Supondo-se essa caracterização inicial negativa, diferentemente do que pensa a maioria dos críticos, o fato do suicídio parecer de forma constante para Quéreas como a única saída possível de situações desesperadoras é, a meu ver, no mínimo ambígua. Um argumento frequentemente utilizado é o de que também Dionísio pensa em suicídio por causa dos seus sentimentos por Calírroe, embora o personagem seja caracterizado pela consciência de que deve agir em conformidade com o que a sociedade espera dele. De fato, há um único momento em que Dionísio, representado de forma mais positiva do que Quéreas no que diz respeito à (tentativa de) manutenção de ideais de masculinidade, também desiste de viver (III.1) por causa da rejeição de Calírroe, ${ }^{13}$ de forma que o Amor é representado como uma emoção irresistível que, se não satisfeita, pode levar um homem à morte. Não estou certa, mesmo assim, de que, ao menos com relação ao texto de Cáriton, o suicídio como resposta à infelicidade no amor seja algo aceitável como reação apropriada, seja no caso de Quéreas, seja no de Dionísio.

Parece-me, no entanto, que em romances posteriores não existe, de fato, essa carga negativa na ideia do suicídio do herói. Talvez a maneira como Eros é representado

\footnotetext{
${ }^{13}$ Em II.6, Dionísio menciona o suicídio, mas logo em seguida se diz que, na verdade, ele ainda tinha esperanças de conquistar Calírroe.
} 
por Cáriton, como algo que desestabiliza os homens, comprometendo sua atuação na esfera pública, tenha ensejado a criação de um tópos romanesco que acaba por perder sua nuança negativa. Em nenhum dos demais romances, o herói tem a mesma complexidade de caracterização de Quéreas e, caso se pense a narrativa de Cáriton como uma espécie de texto fundador do gênero, é possível observar o mesmo acontecendo com outras das convenções do romance. Embora, por exemplo, a ameaça de agressão sexual paire como uma possibilidade sobre Calírroe, nenhum dos seus pretendentes faz, de fato, qualquer tentativa concreta nesse sentido, rejeitando-se sempre a satisfação por meio da força, o que serve, a meu ver, principalmente para enfatizar que esses homens conseguem ter algum controle sobre seu desejo erótico. A heroína Ântia, porém, no segundo romance mais antigo conhecido, As Efesíacas, sofre diversas tentativas de violação, o que nos mostra como um motivo pode ser retomado com função bastante diversa da "original”; todas as heroínas, com exceção de Calírroe, conhecerão homens dispostos a se valer da força para satisfazer seu desejo, ressaltandose, então, muitas vezes a capacidade e obstinação dessas mulheres de preservar sua castidade em situações em que elas se encontram vulneráveis.

Em Quéreas e Calírroe, a guerra é um fator que altera de modo decisivo a caracterização do herói e que permite, como havia notado Balot (1998), que os rivais pelo amor da heroína reassumam de forma adequada suas posições de homens públicos, o que implica o controle das emoções. Essa função da guerra não é vista em nenhum dos outros romances. Mesmo assim, em Dáfnis e Cloé, em que os críticos frequentemente perceberam uma irrelevância da temática da guerra, em que ela só seria inserida como paródia de uma convenção do gênero e como demonstração do poder protetor de Pã sobre o campo, o episódio bélico participa da construção da masculinidade do herói de uma forma mais ampla do que a privilegiada pelo autor na maior parte da narrativa, que trata principalmente de uma aprendizagem sexual. Isso é perceptível porque se forja na narrativa uma relação estreita entre Dáfnis e Pã, um deus cujo âmbito de atuação envolve a guerra de forma não desimportante, seja em narrativas mitológicas (como na atuação como general na campanha de Dionísio na Índia), seja na tradição historiográfica desde o relato de Fidípides registrado em Heródoto (VI.105), que levou os atenienses à crença de que contaram com ajuda de Pã para vencer a batalha de Maratona. Na intervenção do deus no romance, que provoca pânico nos soldados metimnenses que haviam capturado Cloé, dois elementos fundamentais são o eco e a 
siringe, cuja etiologia e relação com Pã são posteriormente explicados em narrativas embutidas.

De fato, o episódio bélico relaciona-se em Dáfnis e Cloé estreitamente com os três mitos etiológicos narrados no romance, cujos elementos comuns envolvem a presença de Pã, a agressividade masculina e a vitimização e metamorfose de uma personagem feminina. Em contraste com essas histórias, no plano humano a convivência entre Dáfnis e Cloé desenvolve-se de forma harmoniosa, sugerindo-se que a raiva e a violência observadas na atitude do deus não devem ter lugar na relação entre eles. O jovem, por outro lado, entra em contato com um aspecto de Pã em que o emprego da violência masculina diz respeito a um uso regrado e coletivo e que é associado a uma esfera de atuação urbana, algo condizente com seu novo status de membro de uma família citadina e rica ao fim da narrativa.

Em Heliodoro, por sua vez, observamos uma representação mais variada de conflitos bélicos, que envolvem não apenas um grande confronto militar entre Etiópia e Pérsia pela posse de minas de esmeralda, mas também embates violentos entre piratas, bandidos e a guarda persa. Por um lado, o próprio herói Teágenes é posto na condição de bandido quando rapta Caricleia e, com ela e com Calasíris, parte de Delfos em direção a terras estrangeiras, onde eles têm de enfrentar uma série de violências. Isso é significativo se lido em conjunto com os diversos momentos em que piratas e bandidos consideram que ele tem todas as características para se tornar um importante membro de seus bandos (I.4.2, V.26, VII.5.5), sugerindo-se a possibilidade de Teágenes não conseguir se reintegrar à sociedade e abraçar a vida de fora da lei. A recusa do herói de participar da batalha entre os boukoloi, liderados por Tíamis, e a guarda persa, motivado pelo desejo de preservar sua vida tendo em vista o amor de Caricleia, ainda que possa ser considerada algo covarde, como ele próprio observa (II.1.2), aponta, então, para o fato de que a violência masculina exibida por meio da habilidade marcial não é a principal qualidade do herói romanesco. Ao contrário, ela parece dizer respeito ao comportamento de um bandido, que dela não pode refrear, e para quem a violência é sempre questão de vida ou morte. As demonstrações atléticas com as quais Teágenes, tanto em Delfos, quanto na Etiópia, pode dar a conhecer suas qualidades masculinas são, assim, uma alternativa ao derramamento de sangue como prova de andreia.

Mesmo na grande guerra travada no romance, a atuação do rei etíope Hidaspes como general é construída para ressaltar sua capacidade estratégica e sua philanthropia, por meio de ações que demonstram seu interesse em preservar o maior número de vidas 
(seja dos seus próprios soldados, seja de inimigos) e oferecer tratamento justo aos vencidos. A forma como o cerco à cidade de Siene e a batalha final se desenrolam servem à caracterização de Hidaspes como um líder ideal, na qual são facilmente percebidos aspectos relacionados a uma tradição que remonta à obra Ciropédia, de Xenofonte. Esse comportamento civilizado em guerra funciona como uma espécie de transição na narrativa das terras egípcias controladas por bandidos (e de Mênfis, onde Caricleia e Teágenes sofrem nas mãos de pessoas dominadas por suas paixões), para uma sociedade (quase) helenizada. A abolição do sacrifício humano na Etiópia como ritual religioso em celebração de uma vitória militar amarra os eventos do romance em uma trama divinamente orquestrada e dá sentido especial ao fato de que os heróis chegam ali como cativos de guerra.

Analisar o tema da guerra a partir de uma abordagem que investiga a representação da masculinidade dos personagens é por princípio problemático porque, no romance grego, ela envolve três períodos distintos; não apenas há uma perspectiva atual sobre o assunto interferindo inevitavelmente na leitura dos textos, mas se trata também de um gênero literário em que se busca representar fatos acontecidos em um período já distante daquele em que as narrativas foram produzidas. A violência praticada por bandidos e a tentativa do estado de controlá-la são elementos que podem ter sido inseridos nos romances em razão de eventos contemporâneos aos autores, ${ }^{14}$ mas há claramente em Cáriton, Longo e Heliodoro o desejo de relacionar os episódios bélicos de seus romances à tradição historiográfica grega (e, no caso de Cáriton, à poesia homérica). Isso levou à sugestão de que a guerra estaria presente no romance por causa de uma representação arcaizante da masculinidade (Lalanne, 2006) em que pegar em armas e lutar com outros homens seriam índice de amadurecimento de um jovem. Como vimos, contudo, nem Dáfnis nem Clitofonte passam por essa etapa e mesmo Teágenes, embora descendente de Aquiles, não se mostra um grande guerreiro no duelo contra o pirata Peloro. No entanto, é evidente que a guerra, no contexto cultural em que os romances foram criados, ainda era percebida como uma situação que distinguia os grandes homens, até porque a andreia é um valor dependente de um contexto de competição. Seria, então, possível perceber algo mais da sociedade que produziu essas narrativas com base no comportamento dos personagens masculinos nos episódios bélicos?

\footnotetext{
${ }^{14}$ Cf. Winkler (1980). Contra Rutheford (2002).
} 
Estudos recentes chamaram a atenção para a constituição de masculinidades no contexto da Segunda Sofística que deliberadamente se afastam de uma concepção mais tradicional. Connolly (2003), por exemplo, ${ }^{15}$ ao explorar as relações entre andreia e paideia em discursos e em textos biográficos sobre os oradores do período, ${ }^{16}$ conclui que (idem, p.290) "o que chama a atenção nas suas negociações dessas relações [...] é que elas unem certos estereótipos negativos acerca da feminilidade e passividade dos professores a uma nova concepção de andreia, que favorece a diplomacia e a resistência em detrimento do risco e da ousadia". Esses especialistas em paideia, portanto, tomariam para si a tarefa tanto de ensinar o comportamento adequado aos jovens com relação à andreia quanto de controlar seus ímpetos naturais de brutalidade, embora eles estivessem "conscientes de que o capital simbólico que eles possuíam era resultado não de grandes feitos em guerra ou mesmo na política, as áreas tradicionais $d a$ andreia”.

Como se buscou evidenciar no primeiro capítulo desta tese, o romance era uma forma literária sofisticada cujo público leitor provavelmente não se distinguia do grupo de pepaideuménoi, homens eruditos, aos quais concernia essa nova concepção de masculinidade, mas, pelo contrário, fazia parte dele. Parece-me que, ao longo da nossa análise do tema da guerra nos romances, ressaltou-se que o valor marcial é algo menor para o herói romanesco e que, por outro lado, o tema possibilita aos romancistas lidar com questões que continuam a ser de grande interesse no período, relacionadas ao controle da raiva e da violência, uma preocupação que tem início no período clássico. ${ }^{17}$ Não sugiro, com isso, que haja um discurso coerente nos três autores analisados que possa ser reconhecido como convencional ao gênero do romance ou que seja empregado com propósito didático, mas que há uma preocupação, comum ao período, em se

\footnotetext{
${ }^{15}$ Cf. também Gleason (1995).

16 Connolly discute passagens de Filóstrato, Dion Crisóstomo, Luciano, Élio Aristides, Favorino e Pólemon.

${ }^{17}$ Cf. Harris (2004) e Roisman (2005). Van Wees (1992) analisa como os heróis homéricos devem ganhar fama e respeito por meio da violência e como a disposição para empregar força é vista como principal aspecto da masculinidade na Ilíada. Nesse sentido, a raiva é um sentimento valorizado (idem, p.154): "anger is the key emotion. It is not just a natural response to a loss of face, but it is required by homeric norms, and instilled even in those who do not spontaneously feel it [...] Anger is needed to overcome hesitation and fear". A competição por status por meio da violência acaba provocando conflito, no entanto, no interior da própria comunidade. Cf. porém Graziosi e Haubould (2003) para uma concepção da masculinidade em Homero na qual a solidariedade tem papel importante.
} 
discutir a raiva masculina e suas consequências negativas nas esferas pública e doméstica e que de alguma forma ela se apresenta nos romances no momento em que a violência é uma necessidade, i.e., durante a guerra. Porém, mesmo um personagem como Clitofonte, passivo que é nas situações de confronto com outros homens, pode ser visto de uma perspectiva mais positiva a partir do momento em que o irascível Tersandro entra em cena com sua "brutalidade natural". De certa forma, a miríade de episódios violentos no romance são uma sequência de exibições de violências apropriadas e não apropriadas.

Aqui reconheço que uma investigação mais profunda de outros autores do período poderia fornecer argumentos mais sólidos para contextualizar histórica e culturalmente a hipótese levantada ao longo desta tese, mas é possível fornecer alguns indícios. ${ }^{18}$ Peter Brown (1992, p.48ss), discutindo a importância do autocontrole para a elite masculina no período imperial, obtido por meio do estudo da retórica, que treinava "os filhos potencialmente violentos da elite", analisa o discurso de controle da raiva, ao observar que o uso da violência era frequente nas relações domésticas e uma prerrogativa de líderes políticos (idem, p.50): ${ }^{19}$

A ênfase no "cuidado de si" que floresceu nos primeiros dois séculos d.C. era, de várias formas, a reação de intelectuais a sua

\footnotetext{
18 Agradeço a Breno Battistin Sebastiani pela indicação, na arguição desta tese, de uma passagem de Marco Aurélio (11.18.5) em que o controle da raiva é precisamente associado à ideia de começar a ser

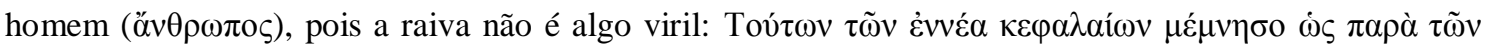

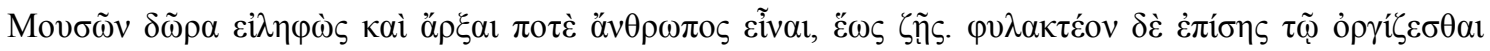

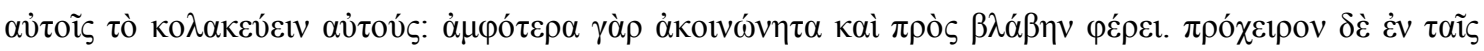

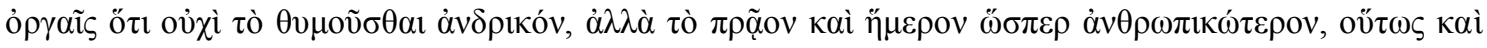

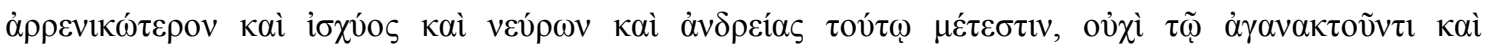

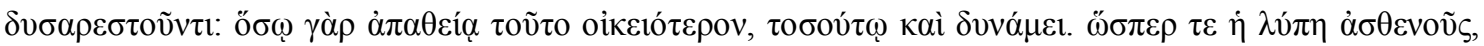

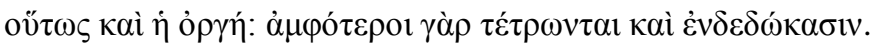

${ }^{19}$ Idem, ibidem: "We are in a world characterized by a chilling absence of legal restraints on violence in the exercise of power. This was not a situation that had begun only with the later empire. For centuries philosophers and teachers had grappled with the intensely personal nature of power in ancient society. Ethical writers of the early empire were obsessed by scenarios of acute dependence. From wives and slaves in the household to the abject courtiers of tyrannical rulers, the lives of so many persons in so many situations appeared to depend on the whim of their superiors. A lurking fear of arbitrary violence, untrammeled by legal and political constraints, insensibly shifted the weight of philosophical discussion towards ethical issues, involving self-formation and control of the passions".
} 
própria percepção sombria da sociedade romana, em que um autocontrole elevado era a única e frágil garantia de humanidade com relação aos outros.

Os romances não apresentam, contudo, uma visão totalmente negativa da raiva, diferentemente de tantos autores que, segundo argumenta Harris (2004), são "absolutistas" em seu ponto de vista, advogando por uma abstenção completa dessa emoção. ${ }^{20}$ Quéreas, por exemplo, é um herói que apresenta uma atitude com relação à raiva em acordo com que diz Aristóteles sobre essa emoção na Retórica (II.2, 1378a31), ${ }^{21}$ segundo o qual ela levaria a um desejo de agir no sentido da obtenção de uma vingança. ${ }^{22}$ Mas Aristóteles é bastante preciso na exposição de que ela deve ser expressa pela motivação certa, contra determinado tipo de pessoa, de uma forma específica e no momento e na duração apropriados (Ética a Nicômaco, IV.5.1125b271126b10). ${ }^{23}$ Tudo o que ele faz de errado a Calírroe é, de certa forma, corrigido quando ele participa da revolta ao lado dos egípcios contra o Grande Rei. Por outro lado, também se mencionou que a orgé, na poesia épica de Homero a Virgílio e nos defixiones do período, era percebida como um importante fator positivo para os homens em situações de disputa. Porém, mesmo essa concepção já havia sido questionada por Cícero, quando ele pergunta como essa "irascibilidade guerreira" (bellatrix irancundia) se expressa no contexto doméstico, com relação à família e aos escravos. "Ela é útil aqui também?" (Oração Tusculana IV.54: ista bellatrix iracundia, cum domum rediit, qualis est cum uxore, cum liberis, cum familia? an tum quoque est utilis?). E, como mencionamos no segundo capítulo desta tese, Harris (op.cit.) identifica em Plutarco um momento em que a ideologia do controle da raiva passa a dizer respeito não apenas a questões políticas, mas principalmente ao contexto familiar. ${ }^{24} \mathrm{O}$ autocontrole de

\footnotetext{
${ }^{20}$ Cf. porém, o estudo mais recente de Kalimtzis (2012, ao qual não tivemos acesso), que critica a visão de Harris por considerar que o autor releva as implicações políticas desse tipo de discurso, argumentando que, na verdade, não se sugeria a recusa total da raiva, mas o seu controle.

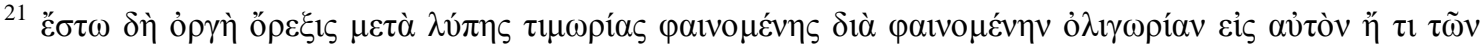

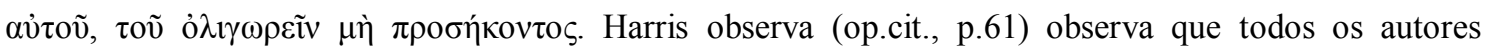
posteriores oferecem definições simplificadas da de Aristóteles.

${ }^{22}$ Sobre ciúme e raiva de Quéreas, cf. também Jones (2012, p.79-89).

${ }^{23}$ Sobre a definição da emoção por Aristóteles, cf. Konstan (2003) e Harris (op.cit, p.58ss).

${ }^{24}$ Harris (op.cit, p.313, n.122) elenca as seguintes ocorrências em De Cohibenda Ira: Sobre relações com amigos: 455f, 460f, 461b, 462ab, 462e, 463c, 464a; com esposas: 455f, 457a, 460f, 461b, 461c, 462ab,
} 
Quéreas concerne, de forma clara, à ambientação criada por Cáriton e à futura liderança política do herói na cidade de Siracusa, pelo fato do chute que ele dá em sua esposa ser um tópos identificado com figuras tirânicas. Concordo, porém, com Haynes (2003), quando ela argumenta que o herói romanesco é sobretudo um marido, não um guerreiro. ${ }^{25}$ A violência que ele pratica contra Calírroe deve, portanto, ser entendida não apenas como uma apropriação de uma ideia presente na tradição historiográfica, mas também como representação extrema de uma violência doméstica nociva ao casamento.

Assim, também em Longo, o caráter irascível e violento do deus Pã exibido nos mitos embutidos (e intrinsecamente relacionado ao desejo erótico) deve ser considerado significativo para Dáfnis, pois são dois aspectos masculinos com os quais ele deverá lidar no seu processo de amadurecimento. Um exemplo negativo no plano humano de como lidar com esses impulsos é a raiva dos jovens metimnenses, que provoca o início de uma guerra, na qual o desejo de vingança leva à pilhagem dos campos de Mitilene, em um comportamento avaliado como próprio de "bandidos" (III.2.1). De certa forma, a atuação de Pã nesse contexto é de contenção, pois ao exigir a devolução de Cloé e de seus animais ao campo, ele promete ser o guia dos metimnenses também no seu retorno para casa (II.27). E a decisão da cidade de Mitilene de aceitar a proposta de paz alude a uma passagem de Tucídides (o debate entre Cleão e Diodoto após o controle da revolta de Mitilene, III.37-48) em que ocorre o triunfo da razão sobre a raiva na deliberação dos atenienses de revogar a decisão anterior de matar todos os homens mitilenos.

Em Heliodoro, por sua vez, essa ideologia do controle da raiva e da violência é identificável na conduta de Hidaspes por oposição tanto ao Grande Rei (que não entra em cena, mas cuja crueldade é mencionada pelo sátrapa Oroodantes) quanto à forma

464 ; com crianças: 455f, 462e, 464a. Também em Conjugalia Praecepta $(27=141 \mathrm{e}-\mathrm{f})$, discurso destinado aos noivos, Plutarco observa que sacrifícios são oferecidos a Hera para que a raiva (ỏpyń) nunca tenha lugar no casamento.

${ }^{25}$ Haynes (2002, p.97) parte da hipótese de Louraux (1995) de que no período clássico as definições de masculino e feminino podiam ser estabelecidas a partir do conceito de pónos, identificando-se assim homens como "guerreiros" e mulheres como "mães": "Instead of the old 'social' model of self-definition from the Classical period where man was primarily defined as 'warrior' and woman as 'mother', I detect in the world of the novel a new 'personal' model with man as 'husband' and woman as 'wife'. Within this model there is an important shift in signification where 'ponos' as work, as one's means to self-definition becomes 'ponos' as suffering itself. Thus, in the fiction of the novel both man and woman define themselves as husband and wife through their suffering and lamentation which is the proof of the strength of their bond". 
como são caracterizados os embates entre piratas e bandidos. Isso poderia ser lido apenas como uma oposição convencional entre um líder político e militar "helenizado" e seu contraponto bárbaro, mas o discurso de Heliodoro revela-se mais complexo. Nesse sentido, se a atitude de Teágenes ao longo da narrativa resultou em que ele fosse considerado por boa parte dos críticos como um dos heróis romanescos de menos brilho e iniciativa, ela também contrasta com a do bandido Tíamis, que vê na violência o único caminho de sobrevivência e de retorno à sociedade. A philanthropia de Hidaspes, por sua vez, um personagem que favorece a diplomacia em detrimento da luta armada, para além de remontar ao Ciro de Xenofonte, parece estar em sintonia com uma nova ideologia de controle da raiva reconhecível em um período mais tardio do Império (a partir do final do século III d.C.), conforme observa Harris (op.cit., p.257-258): “em boa parte da literatura, o controle da raiva tende a se transformar em uma delicadeza e philanthropia gerais e o controle do imperador sobre a raiva é quase ausente dos panegíricos em prosa latinos". ${ }^{26}$

Desse modo, é possível questionar se, de fato, a representação do herói ganha nuança arcaizante por meio dos episódios bélicos ou se o valor marcial não é suplantado nesse contexto por uma exibição de autocontrole das emoções, um traço constitutivo do homem pepaideuménos e que, nesse momento, tem maior relevância para a definição da masculinidade. Muitos dos personagens que empregam uma violência inadequada nos romances - Quéreas, Dórcon, os jovens metimnenses, Hipothoo, Tíamis, entre outros não são os vilões da história, ao contrário, aos dois últimos, embora sejam bandidos, é reservado até um final feliz. Mesmo o distinto Teágenes deixa claro que tem algo a aprender quando reage afirmando que vai matar o noivo de Caricleia ao saber que ela era prometida a outro (IV.6.7). ${ }^{27}$ Ceder aos impulsos violentos é uma possibilidade mesmo para os homens nobres; aprender a controlá-los é o que se esperava dos jovens heróis dos romances (e, provavelmente, de seus leitores).

\footnotetext{
${ }^{26}$ Harris analisa onze panegíricos latinos datados entre os anos 289 e 289 d.C. e também textos de Menandro, o Retor (sobretudo o tratado II) e Eusébio, Juliano, Temístio, Libânio, Símaco, Sinésio e Claudiano.

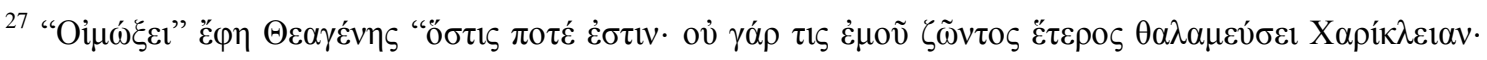

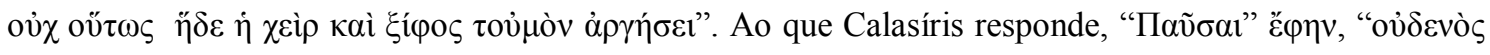

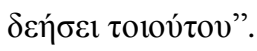




\section{REFERÊNCIAS BIBLIOGRÁFICAS}

Edições, traduções e comentários (romances e fragmentos):

ACHILLE TATIUS. Le Roman de Leucippé et Clitophon. (Texte établi et traduit par JP. Garnaud), Paris: Les Belles-Lettres, 1991.

ACHILLES TATIUS. Leucippe and Clitophon. (translated by T. Whitmarsh), New York: Oxford University Press, 2002.

AQUILES TÁCIO. Os amores de Leucipe e Clitofonte. (Introdução, tradução e notas de A. Pena), Lisboa: Edições Cosmos, 2005.

CÁRITON. Quéreas e Calírroe. (Tradução, introdução e notas de M.F. Sousa e Silva), Lisboa: Cosmos, 1996.

- Le Roman de Chairéas et Callirhoé (Texte établi et traduit par G. Molinié et revisé par A. Billaut), Paris: Les Belles-Lettres, 1989.

Callirhoe. (Edited with English Translation - G.P. Goold), Loeb Classical Library, Cambridge: Harvard University Press, 1995.

De Callirhoe narrationes amataoriae. (Editonem curauit B. P. Reardon). Bibliotheca Teubneriana, München, Saur Verlag, 2005.

HÉLIODORE. Les Éthiopiques: Théagène et Chariclée. (Texte établi par R.M. Rattenbury et T.W. Lumb, traduit par J. Maillon), Paris: Les Belles-Lettres, tomo I, 2011; tomo II e tomo III, 2003 (primeira edição de 1935).

HELIODORUS. Aethiopica. (A. Colonna recensuit). Roma: Typis Regiae Officinae Polygraphicae, 1938.

LONGO SOFISTA. Dafni e Cloe (Introduzione, traduzione e note di M. Pattoni), Milano: Bur, 2005.

LONGO. Dáfnis e Cloé. Campinas: Pontes, 1990.

LONGUS. Pastorales - Daphnis et Chloe. (Texte établi et traduit par G. Dalmeyda). Paris: Belles Lettres, 1934.

. Pastorales - Daphnis et Chloe. (Texte établi et traduit par J-R. Vieillefond). Paris: Belles Lettres, 1987.

. Daphnis et Chloe (edidit M. Reeve), Stuttgart/Leipzig: Teubner, 1994.

Daphnis and Chloe. (Bilingual edition with commentary and reprint of M.

Reeve. Daphnis et Chloe / Longus, Stuttgart: Teubner, 1982). Aris and Phillips Classical Texts. Oxford: Oxbow Books, 2004. 
PHOTIUS. Bibliothèque - tome I-VII. (Texte établi et traduit par René Henry). Paris : Société d'édition les Belles lettres, 1965-1977.

REARDON, B. (ed). Collected Ancient Greek Novels. Berkeley: University of California Press, 1989.

STEPHENS, S. \& WINKLER, J. (eds). Ancient Greek Novels: The Fragments. Introduction, Text, Translation and Commentary. Princeton: 1993.

VILBORG, E. Leucippe and Clitophon - A Commentary. Stockholm: Almqvist \& Wiksell, 1955.

XENOFONTE DE ÉFESO. As Efesíacas (tradução, introdução e notas de V. Ruas). Lisboa: Edições Cosmos, 2008.

XENOPHON. Cyropaedia - 2 vol. (With an English translation by W. Miller). Harvard: Harvard University Press, 1960/1958.

XÉNOPHON. Cyropédie (Texte établi et traduit par E. Delebecque), Paris: Les BellesLettres, tomo I, 2010 (primeira edição 1971); tomo II, 2003 (primeira edição 1973); tomo III, 2003 (primeira edição 1978).

XÉNOPHON d'ÉPHÈSE. Les Ephésiaques (Texte établi et traduit par G. Dalmeyda), Paris: Les Belles Lettres, 1926.

XENOPHON EPHESIUS. Ephesiacorum Libri V (Edidit A. Papanikolau), Leipzig: Teubner, 1978.

\section{Outros autores:}

AGAPITOS, P. 'Narrative, rhetoric, and 'drama' rediscovered: scholars and poets in Byzantium interpret Heliodorus”, In: HUNTER, R., 1998, p.125-155.

ALTHEIM, F. Literatur und Gesellschaft in ausgehenden Altertum, Halle, 1948.

ALSTON, R. "The Revolt of the Boukoloi: Geography, History and Myth", In: HOPWOOD, K. (ed.), Organised Crime in the Ancient World, London: Duckworth, 1999, p. 129-53.

ALVARES, J. "The Drama of Hippothous in Xenophon of Ephesus' "Ephesiaca", The Classical Journal, vol. 90, n. 4, 1995, p. 393-404.

1997, p. 613-29. .“Chariton's Erotic History”, American Journal of Philology 118, 
. "Some Political and Ideological Dimensions of Chariton's Chaireas and Callirhoe”, Classical Journal 97, 2001-2002, p. 113-44.

ANDERSON, G. Eros Sophistes - Ancient Novelists at Play, Chico: Scholars Press, 1982.

London: Croom Helm, 1984.

Ancient Fiction: The Novel in the Graeco-Roman World. The Second Sophistic: a cultural phenomenon in the roman empire. London: Routledge, 1993.

BALOT, R. "'Foucault, Chariton, and the masculine self”, Helios 25.2, 1998, p. 139-62.

BARNS, J. "Egypt and the Greek Romance", Akten 8, Kongr. für Papyr., Mitteilungen aus der Papyrussammlung der Oesterreich, Neue Serie, éd. Gerstinger, 5. Folge, Wien, 1956.

BASSI, K. "The Semantics of Manliness in Ancient Greece", In: ROSEN, I., SLUITER, R., 2003, p.25-57.

BARTSCH, S. Decoding the Ancient Novel, Princeton: Princeton University Press, 1989.

BARTSCH, W. Der Chariton-Roman und die Historiographie, Leipzig: Diss. Univ. Leipzig, 1934.

BASZLES, M. "De l'histoire au roman: la Perse de Chariton”, In: BASLEZ, M., HOFFMAN, P., TRÉDÉ, M. (eds), 1992, p.199-212.

BASlEZ, M., HOFFMAN, P., TRÉDÉ, M. (eds). Le Monde du Roman Grec. Paris: École Normale Supérieure, 2000.

BEATON, R. "The Byzantine Revival of the Ancient Novel”, In: SCHMELING, G., 1996, p. 713-733.

BERNARDI, J. “Aspects Poétiques et Musicaux de Daphnis et Chloé”, In: In: BASLEZ, M., HOFFMAN, P., TRÉDÉ, M. (eds), 1992, p. 27-32.

BERRY, J. Narrative and Identity in Heliodoros' Aithiopika. Tese de doutorado. Chicago: University of Chicago, 2000.

BERTONI, C., FUSILlO, M. "Heliodorus Parthenopaeus: the Aithiopika in baroque Naples”, In: HUNTER, R.,1998, p. 157-81. 
BESTON, P. "Hellenistic Military Leadership”. In: van WEES, H., 2009, p.315336.

BEYE, C. "Jason as love hero in Apollonius' Argonautika" Greece , Rome Bulletin Studies 10, 1969, p. 31-55.

BILLAUT, A. "De l'histoire au roman: Hermocrate de Syracuse", Revue de Études Grecques, n.102, 1989, p.540-548

La Création Romanesque dans la Littérature Grecque à l'Époque Impériale, Paris: Presses Universitaires de France, 1991.

BLANCHARD, J. M. "Daphnis et Chloé: Histoire de la mimesis", Quaderni Urbinati di Cultura Classica, n.20, 1975, p.39-62.

BOMPAIRE, J. Lucien Écrivain: Imitation et Création. Paris: Boccard, 1958.

“Comment lire les Histoires Vraies de Lucien?”, Latomus, vol.201, 1988, p. 31-39.

BORGEAUD, P. The Cult of Pan in Ancient Greece, Chicago: The University of Chicago, 1988.

BOWERSOCK, G. Fiction as History: Nero to Julian. Berkeley: University of California Press, 1994.

BOWIE, E., HARRISON, S. "The Romance of the Novel", The Journal of Roman Studies, Vol. 83, 1993, pp. 159-178.

BOWIE, E. "Theocritus' seventh Idyll, Philetas and Longus”, Classical Quaterly, vol.35, n. 1, 1985, p.67-91.

. “The Readership of Greek Novels". In: TATUM, J. (ed.), 1994a, p. 435-459.

. "The Ancient Readers of the Greek Novels", In: SCHMELING, G. (ed.), 1996, p.87-107.

"Phoenician Games in Heliodorus' Aithiopika", In: HUNTER, R., 1998, p.1-18.

. "The chronology of the earlier Greek novels since B.E. Perry: revisions and precisions", Ancient Narrative 2, 2002, p.47-63. 
"Pulling the Other? Longus on Tragedy", In: ELSNER, J. et al. (eds). Visualizing the Tragic: Drama, Myth and Ritual in Greek Art and Literature, Oxford: Oxford University Press, 2007, p.338-352.

BRANDAO, J. A Invenção do Romance, Brasília: UNB, 2005.

BRANHAM, R. "A Truer Story of the Novel?", In: BRANHAM, R. (ed.), Bakhtin and the Classics, Evanston, Northwerstern University, 2002, p.161-186.

BRAUND, S., MOST, G. (eds.). Ancient Anger: perspectives from Homer to Galen, Yale Classical Studies 32, Cambridge: Cambridge University Press, 2003.

BRAUND, S., GILBERT, S. "An ABC of epic ira: anger, beasts, and cannibalism”, In: BRAUND, S., MOST, G. (eds.), 2003, p.250-283.

BROWN, P. Power and Persuasion in Late Antiquity: Towards a Christian Empire, Madison: University of Wisconsin Press, 1992.

CAIRNS, D. L. "Ethics, ethology, terminology: Iliadic anger and the crosscultural study of emotion”, In: BRAUND, S., MOST, G. (eds.), 2003, p.11-49.

CAHOON, L. "The Bed as a Battlefield: Erotic Conquest and Military Metaphor in Ovid's Amores", The American Philological Association, vol.118, 1988, p.293-307.

CAPILUPO, A. "Il Genere Romanzesco nell'Antiquità Graeca e Romana: Terminologia e Teoria”, Aion, vol.28, 2006, p.113-34.

CHALK, H. "Eros and the Lesbian Pastorals of Longos". Journal of Hellenic Studies, vol.80, 1960, p.32-51.

CHEYNS, A. "Le dieu Pan et l'expression de la violence in Daphnis et Chloé", In: POUDERON, B., HUNZIGER, C., KASPRZYK, D. (eds.), 2001, p.165-180.

CHEW, C. "The Representation of Violence in the Greek Novels and Martyr Accounts”, In: PANAYOTAKIS, S., ZIMMERMAN, M., KEULEN, W. (eds.), 2003, p.129-141.

CONNELL, R. Masculinities: Second Edition, Berkeley: University of California Press, 2005.

CONNORS, C. "Chariton's Syracuse and its Histories of Empire", In: PASCHALIS, M., FRANGOULIDIS, S. (eds.), Space in the Ancient Novel, Groningen: Barkhuis, 2002, p. 12-26. 
CRESCI, L. "The Novel of Longus the Sophist and the pastoral tradition", In: SWAIN S. (ed.), 1999, p.201-42.

CUEVA, E. "Longus and Thucydides: a new interpretation", Greek, Roman and Bizantyne Studies 39, n.4, 1998, p.429-440.

"Longus in the Mir Istkusstva: Léon Bakst, Maurice Ravel and Marc Chagall”, Ancient Narrative 1, 2000-2001, p.152-159.

The Myths of Fiction: Studies in the Canonical Greek Novels. Ann Arbor: The University of Michigan Press, 2004.

DE TEMMERMAN, K. (2009). "Chaereas revisited. Rhetorical control in Chariton's ideal novel Callirhoe", Classical Quaterly n. 59, v.1, p.247-262.

DOODY, M. The True Story of the Novel, New Brunswick: Rutgers University Press, 1996.

DOULAMIS, K. “All's Well that Ends Well: Storytelling, Predictive Signs, and the Voice of the Author in Chariton's Callirhoe", Mnemosyne, Volume 65, Number 1, 2012, p. 18-39.

DOWDEN, K. “Heliodoros: Serious Intentions”, Classical Quarterly, Vol. 46, n. 1, 1996, p. 267-285.

. "Reading Diktys: the Discrete Charm of Bogosity". In: PASCHALIS, M., PANAYOTAKIS, S., SCHMELING, G. (eds.), 2009, p. 155-167.

DUE, B. The Cyropaedia: Xenophon's Aims and Methods, Aarhus: Aarhus University, 1989.

DURHAM. D. "Parody in Achilles Tatius”, Classical Philology 33, 1938, p. 119.

EDWARDS, D. "Defining the Web of Power in Asia Minor: The Novelist Chariton and His City Aphrodisias", Journal of the American Academy of Religion, vol. 62, 1994, p. 699-718.

. "Pleasurable Reading or Symbols of Power? Religious Themes and Social Context in Chariton", In: HOCK, R., CHANCE, J., PERKINGS, J. (eds.), Ancient Fiction and Early Christian Narrative, Atlanta: Society of Biblical Literature, 1998, p.31-46. 
EFFE, B. "Longus: towards a history of bucolic and its function in the Roman empire”. In: SWAIN S. (ed.), 1999, p.189-209.

EGGER, B. "Looking at Chariton's Callirhoe", In: MORGAN, J., STONEMAN, R. (eds.), 1994a, p.31-48.

"Women and marriage in the Greek novels: the boundaries of romance”, In: TATUM, J (ed.), 1994b, p.260-80.

. "The Role of Women in the Greek novel: Woman as Heroine and Reader”, In: SWAIN, S. (ed.), 1999, p. 108-136.

EPSTEIN, S. “Longus' werewolves”. Classical Philology, 1995, n. 90, p. 58-73. "The Education of Daphnis: Goats, Gods, the Birds and the Bees". Phoenix, vol.56, n.1/2, 2002, p.25-39.

FARAONE, C. "Thumos as masculine ideal and social pathology in ancient Greek magical spells”. In: BRAUND, S., MOST, G. (eds.), 2003, p. 144-162.

FARBER, J. "The Cyropaedia and Hellenistic Kingship", The American Journal of Philology, Vol. 100, n. 4, 1979, p. 497-514.

FISCHER, N. "Violence, masculinity and the law in classical Athens", In: FOXHALL, L., SALMON, J., 1998a, p.68-97.

FOXHALL, L., SALMON, J. When Men Were Men: Masculinity, Power, and Identity in Classical Antiquity. London and New York: Routledge, 1998a.

Thinking Men: Masculinity and its SelfRepresentation in the Classical Tradition, London and New York: Routledge, 1998b.

FOUCAUlT, M. História da Sexualidade - O Cuidado de Si. Rio de Janeiro: Edições Graal, 2002.

FUSILLO, M. Naissance du Roman, Paris: Du Seuil, 1991.

"Metamorphosi Romanesche dell'Epica". In: MONTANARI, F.,

RENGAKOS, A. (eds.), La Poesie Épique Grecque: Métamorphoses d"un Genre Littéraire, Vandoeuvres/Genève, 2005, p.271-307.

. "Epic, Novel”, In: MORETTI, F. The Novel: Forms and Themes,

2006, Princeton: Princeton University Press, p.32-63.

GABBA, E. "True History and False History in Classical Antiquity", The Journal of Roman Studies, vol. 71, 1981. 
GALE, M. "Militia Amoris and the Ironies of Elegy", The Journal of Roman Studies, vol.87, 1997, p.77-91.

GERA, D. Xenophon's Cyropaedia: Style, Genre and Literary Technique. Oxford: Oxford University Press, 1993.

GLEASON, M. Making Men: Sophists and Self-Presentation in Ancient Rome. Princeton: Princeton University Press, 1995.

GOLDHILL, S. Foucault's Virginity: Ancient Erotic Fiction and the History of Sexuality, Cambridge: Cambridge University Press, 1995. . Who Needs Greek?, Cambridge: Cambridge University Press, 2002.

GRAVERINI, L., KEULEN, W. "Roman fiction and its audience: seriocomic assertions of authority". In: PASCHALIS, M., PANAYOTAKIS, S., SCHELING, G. (eds.), 2009, p.197-217.

GRAZIOSI, B., HAUBOULD, J. (2003). "Homeric Masculinity: HNOPEH and АГHNOPIH", The Journal of Hellenic Studies, vol. 123, p.60-76.

GREEN, P. "Longus, Antiphon and the topography of Lesbos", Journal of Hellenic Studies 102, 1982, p.210-214.

GRUNEWALD, T. Bandits in the Roman Empire: Myth and Reality, London: Routledge, 2004.

GUEZ, J.-P. “Pourquoi Théron n'est-il pas amoureux?”, In: POUDERON, B., HUNZIGER, C., KASPRZYK, D. (eds.), Les personnages du roman grec: Actes du colloque de Tours, Lyon, 2001, p. 101-10.

GUNDERSON, E. Staging Masculinity: The Rhetoric of Performance in the Roman World. Ann Arbor: University of Michigan Press, 2000.

HÄGG, T. Narrative technique in the ancient Greek romances: Studies of Chariton, Xenophon of Ephesus and Achilles Tatius. Stockholm: Svenka Institutet i Athen, 1971.

The Novel in Antiquity, Oxford, Basil Blackwell, 1983. 
. "'Calirrhoe' and 'Parthenope': The beginning of the historical novel".

Classical Antiquity, vol.26, n.2, 1987, p.184-204.

. "Orality, Literacy and the 'Readership' of the Early Greek Novel".

In: MORTENSEN, L., EIDE, T. (eds.), 2004a, p.109-140 (publicado originalmente em 1994).

. "The Ephesiaca of Xenophon Ephesius - Original or Epitome?". In:

MORTENSEN, L., EIDE, T., 2004b, p.159-198 (publicado originalmente em 1969).

HALDEN, J. "Stage-Terms in Heliodorus's Aethiopica", Harvard Studies in Classical Philology, Vol. 5, 1894, p. 1-43.

HANSEN, W. "Idealization as a Process in Ancient Greek Story-Formation", Symbolae Osloenses, 72, 1997, p. 118-23.

HARRIS, W. Restraining Rage: The Ideology of Anger Control in Classical Antiquity, Cambridge/London: Harvard University Press, 2004.

HARRISON, S. "The Milesian Tales and the Roman Novel", Gronigen Colloquia on the Novel, vol. 9, 1998, p.61-73.

HARRISON S., PASCHALIS M., FRANGOULIDIS, S. Metaphor and the Ancient Novel. Groningen: Groningen University Library/Barkhuis, 2005.

HAYNES, K. Fashioning the Feminine in the Greek Novels. London: Routledge, 2002.

HAYWOOD, C., MAC AN GHAILL. Men and Masculinities: Theory, Research and Social Practice, Philadelphia: Open University Press, 2003.

HEATH, M. "Justice in Thucydides' Athenian Speeches", Historia: Zeitschrift für Alte Geschichte, bd. 39.4, 1990, p. 385-400.

HELMS, J. Character Portrayal in the Romance of Chariton, The Hague/Paris: Mouton, 1966.

HILTON, J. "War and Peace in the Ancient Greek Novel". Acta Classica, vol.48, 2005,p.57-85. 
HOBBS, A. Plato and the Hero: Courage, Manliness and the Impersonal Good, Cambridge: Cambridge University Press, 2000.

HOLZBERG, N. The Ancient Novel - an Introduction. London: Routledge, 1995. ."Ctesias". In: SCHMELING, G. (ed.), 1996, p.629-632. "Utopias and Fantastic Travel: Euhemerus, Iambulus". In:

SCHMELING, G. (ed.), 1996, p.621-628.

HOPWOOD, "'All that may become a man': the bandit in the ancient novel”, In: FOXHALL, L., SALMON, 1998a, p.195-204.

HORNBLOWER, S. "Warfare in ancient literature: the paradox of war", In: SABIN, P., VAN WESS, H., WHITBY, M. (eds). The Cambridge History of Greek and Roman Warfare. Vol.1, Cambridge University Press, 2008, p.22-53. Press, 1983.

HUNTER, R. A Study of Daphnis and Chloe, Cambridge: Cambridge University

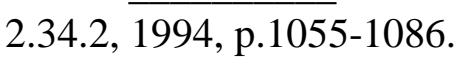
"History and historicity in the romance of Chariton", ANRW “Longus”, In: SCHMELING, G., 1996, p.361-385.

Vol. 21. Cambridge: 1998.

(ed.). Studies in Heliodorus, Cambridge Philological Society, Suppl. HUNTER, R., 1998, p. 40-59

."The Aithiopika of Heliodoros: beyond interpretation?", In: . "Philip the Philosopher on the Aithiopika of Heliodorus", In: HARRISON, J., PASCHALIS, M., FRANGOULIDIS, S. (eds.), Metaphor and the Ancient Novel, Groningen, Barkhuis, 2005, p. 123-138.

York: Walter de Gruyter, 2008, p.775-789.

JOHNE, R. "Women in the Ancient Novel”. In: SCHMELING, G. (ed.), 1996, p. 151-207.

JONES, M. Playing the Man: performing masculinities in the ancient Greek novel, Oxford: Oxford University Press, 2012.

KAIMIO, M. "How to Enjoy a Greek Novel: Chariton Guiding His Audience", Arctos 30, 1996, p. 49-73.

KALIMTZIS, K. Taming Anger: The Hellenic Approach to the Limitations of Reason, London: Bristol Classical Press, 2012. 
KARLA, G. Fiction on the fringe: novelistic writing in the post-classical age. Leiden/Boston: Brill, 2009.

KASPRZYK, D. "Théron, pirate, conteur et narrateur dans le roman de Chariton”, In: POUDERON, B., HUNZIGER, C., KASPRZYK, D. (eds.), 2001, p.149164.

KERÉNYI, K. Die griechisch-orientalische Romanliteratur in religionsgeschichtlicher Beleuchtung, Darmstadt: 1927.

KESTNER, J. "Ekphrasis as frame in Longus' Daphnis and Chloe", Classical World 67, 1973, p.166-171.

KONSTAN, D. Sexual Symmetry: Love in the Ancient Novel and Related Genres, Princeton: Princeton University Press, 1994.

In: BRAUND, S., MOST, G. (eds.), 2003, p. 99-120.

" "Aristotle on anger and the emotions: the strategies of status".

LALANNE, S. Une éducation grecque: rites de passage et construction des genres dans le roman grec ancien, Paris: Éditions La Découverte, 2006. Press, 1989.

LAMBERTON, R. Homer the Theologian, Berkeley, University of California

LAPLACE, M. "Les légendes troyennes dans le roman de Chariton Chairéas et Callirhoe"”, Révue des Études Grecques, vol. 93, 1980, p. 83-125.

LAVAGNINI, B. Studi sul romanzo greco, Messina, D’Anna, 1950.

LENDON, J. "Homeric Vengeance and the outbreak of Greek wars", In: VAN WEES, H. (org.), 2009, p.1-30.

LÉTOUBLON, F. Les Lieux Communs du Roman, Leiden, New York, Cologne: Brill, 1993.

LEVIN, D. "War and Peace in Early Roman Elegy", ANRW II.30.1, Berlin, Walter de Gruyter, 1982, p.418-538.

LONERGRAN, B. "Roman Banditry: Scorning Senatorial Skullduggery in Sallust”, Penn History Review 18.1, 2010, p.70-94.

LONIS, R. "Les Éthiopiens sous le regard de l'Héliodore”, In: BASLEZ, M., HOFFMAN, P., TRÉDÉ, M. (eds), 1992, p.232-241. 
LORAUX, N. The Experiences of Tiresias: The Feminine and the Greek Man, Princeton: Princeton University Press, 1995.

LOURENÇO, F. Poesia grega de Álcman a Teócrito, Lisboa: Cotovia, 2006.

LOWE, N. The Classical Plot and the Invention of Western Narrative, Cambridge: Cambridge University Press, 2000.

LUGINBILL, R. “Chariton's Use of Thucydides' History in Introducing the Egyptian Revolt (Chaireas and Callirhoe 6.8)", Mnemosyne 53, 2000, p. 1-11.

The Classical Journal, Vol. 97, n.3, 2002, p. 233-247.

LYNE, R. "The Life of Love", In: MILLER, P., Latin Erotic Elegy, London, Routledge, 2002, p.348- 365

MACQUEEN, B. Myth, Rhetoric and Fiction: A Reading on Longus' Daphnis and Chloe. Lincoln: University of Nebraska Press, 1990.

MARITZ, J. "The Role of Music in Daphnis and Chloe", Groningen Colloquia on the Novel vol.4, 1991, p.57-67.

MASON, H. J. "Longus and the topography of Lesbos". The American Philological Aassociation 109, 1979, p.149-163.

1995, p. 263-266

. "Romance in a limestone landscape". Classical Philology 90, . "Chaireas in Chariton and New Comedy", Classical Bulletin, vol. 78, 2002, p. 21-7.

“'The 'aura of Lesbos' and the opening of Daphnis and Chloe"”. In: BYRNE, S., CUEVA, E., ALVARES, J. Authors, Authority and Interpreters in the Ancient Novel. Groningen: Groningen University Library, Barkhuis, 2006, p. 186-195.

McDONNELL, M. Roman Manliness: Virtus and the Roman Republic. Cambridge: Cambridge University Press, 2006.

McINERNEY, J. "Plutarch's Manly Women". In: ROSEN, I., SLUITER, R. (eds.), 2003, p.319-341. 
MERKELBACH, R. Roman und Mysterium in der Antike, Munich, 1962.

MERKLE, S. "The truth and nothing but the truth: Dictys and Dares", In: SCHMELING, G. (ed.), 1996, p.563-80.

MORALES, H. Vision and Narrative in Achilles Tatius' Leucippe and Clitophon. Cambridge: Cambridge University Press, 2005a.

. "Metaphor, Gender and the Ancient Greek Novel". In: HARRISON, S., PASCHALIS, M., FRANGOULIDIS, S., 2005b, p.1-22.

55. ."The History of Sexuality", In: WHITMARSH, T., 2008, p.39. "Challenging some orthodoxies: the politics of genre and the ancient Greek novel”. In: KARLA, G., 2009, p.1-12.

MORALES, M., MARISCAL, L. "The relationship between Achilles and Patroclus according to Chariton of Aphrodisias". Classical Quaterly 53, 2003, p.292295.

MORGAN, J. A Commentary on the Ninth and Tenth Books of the Aithiopika of Heliodoros. Diss. Oxford, 1979.

. "History, romance and realism in the Aithiopika of Heliodoros", Classical Antiquity 1, 1982, 221-65.

."Lucian's True Histories and The Wonders Beyond Thule of Antonius Diogenes”, Classical Quaterly, vol.35, 1985, p.475-490.

. "A Sense of the Ending: The Conclusion of Heliodoros' Aithiopika", Transactions of the American Philological Association, Vol. 119, 1989a, p. 299-320.

. "The Story of Knemon in Heliodoros' Aithiopika", The Journal of Hellenic Studies, vol. 109, 1989b, p. 99-113.

"Make-Believe and Make Believe: the fictionality of the greek novels", In: GILL, C., WISEMAN, T. (eds.), Lies and Fiction in the Ancient World, Austin, University of Texas Press, 1993, p. 175-229.

"Daphnis and Chloe: love's own sweet story". In: MORGAN, J., STONEMAN, R. (eds.), 1994, p.64-79. 
. "Heliodoros", In: SCHMELING, G. (1996), p. 417-455.

. "Longus, Daphnis and Chloe: a bibliographical survey, 1950-

1995”. ANRW 2.34.3, 1997, p.2208-76.

. "The story of Knemon in Heliodoros' Aithiopika", In: SWAIN,

S., 1999, p.259-284.

. "Nymphs, Neighbours and Narrators: a Narratological Approach

to Longus”, In: PANAYOTAKIS, S., ZIMMERMAN, M., KEULEN, W. (eds), 2003, p.171-190.

. “Chariton”, In: DE JONG, I., NÜNLIST, R., BOWIE, A. (eds.),

Narrators, Narratees, and Narratives in Ancient Greek Literature: Studies in Ancient Greek Narrative I, Leiden: Brill, 2004, p. 479-87.

"Un discours figuré chez Heliodore: 'Comment, en disant l'inverse de ce qu'on veut, on peut accomplir ce qu'on veut sans sembler dire l'inverse de ce qu'on veut", In: POUDERON, B., PEIGNEY, J. (eds.), Discours et débats dans l'Ancien Roman. Actes du Colloque de Tours, 21-23 octobre 2004, Lyon: Maison de l’Orient et de la Méditerranée, p.51-62.

. "Intertextuality”, In: WHITMARSH, T., 2008, p.218-236.

. "Fiction and History: Historiography and the Novel". In:

MARINCOLA, J. (ed.) The Blackwell Companion to Greek and Roman Historiography, vol.2, Malden: Blackwell Publishing, 2007, p.553-563.

MORTENSEN, L., EIDE, T. (eds.), Parthenope: Selected Studies in Ancient Greek Fiction, Copenhagen: Museum Tusculanum, 2004.

NABER, S. “Ad Charitonem”, Mnemosyne 29, 1901, p. 92-9.

NADON, C. Xenophon's Prince: Republic and Empire in the Cyropaedia, Berkeley, University of California Press, 2001.

NORTWICK, T. Imagining men: ideals of masculinity in ancient Greek culture, Westport: Praeger, 2008. 
ORWIN, C. "The Just and the Advantageous in Thucydides: The Case of the Mytilenaian Debate", The American Political Science Review, vol. 78, n. 2, 1984, p. 485-494.

O'SULLIVAN, J. Xenophon of Ephesus, his compositional technique and the birth of the novel, Berlin/New York: Walter de Gruyter, 1995.

PANAGAKOS, K. Criminal Elements: The evolution of the outlaw in the ancient novel. Tese de doutorado. The Ohio State University, 2004.

PANAYOTAKIS, S., ZIMMERMAN, M., KEULEN, W. (eds). The Ancient Novel and Beyond. Leiden/Boston: Brill, 2003.

PASCHALIS, M. "The Narrator as Hunter: Longus, Virgil and Theocritus". In: HARRISON S., PASCHALIS M., FRANGOULIDIS, S., 2005, p. 50-67.

PASCHALIS, M., PANAYOTAKIS, S., SCHMELING, G. (eds.), Readers and Writers in the Ancient Novel, Groningen: Barkhuis, 2009.

PERRY, B. "Chariton and his romance from a literary-historical point of view", American Journal of Philology, n.51, 1930, p.93-104.

. "The Egyptian Legend of Nectanebus", The American Philological Association, n. 97, 1966, p.327-33.

. The ancient romances: a literary-historical account of their origines, Berkeley/Los Angeles: University of California Press, 1967.

PHILIPPIDES, M. “The 'digressive' aitia in Longus”. Classical World, 81, 1980, p.193-199.

1983, p. 32-35. . "The prooemium in Longus' Lesbiaka", Classical Bulletin,

PINHEIRO, M. F. “"'Calasiris' Story and its Narrative Significance in Heliodorus' Aethiopica", Groningen Colloquia on the Novel 4, 1991, p. 69-83.

."The Nachleben of the Ancient Novel in Iberian Literature in the Sixteenth Century", In: SCHMELING, G. (ed.), 1996, p.775-811.

- "O conceito de diegema (narratio) na retórica antiga e na moderna crítica literária", In: FERREIRA, J. (org.), A Retórica Greco-Latina e a sua 
Perenidade, Actas do Congresso, Porto: Fundação Eng. Antonio de Almeida, 2000, vol.I, p.467-479.

PINHEIRO, M., SKINNER, M., ZEITLIN, F. (eds.). Narrating Desire: Eros, Sex and Gender in the ancient novel, Berlin: Walter de Gruyter, 2012.

PLETCHER, J. "Euripides in Heliodoros' Aithiopika 7-8”, Groningen Colloquia on the Novel 9, 1998, p.17-27.

POUDERON, B. (ed.), Le Personnages du Roman Grec, Lyon: Maison de l'Orient et de la Méditerranée - Jean Pouilloux, 2001.

QUETT, M-H. "Romans grecs, mosaïques romaines", In: BASLEZ, M., HOFFMAN, P., TRÉDÉ, M. (eds), 1992, p.125-160.

REARDON, B. Courants Littéraires Grecs des Ile e IIIe siècles après J.C. Paris: Les Belles-Lettres, 1971.

(ed.), 1994a, p.135-147.

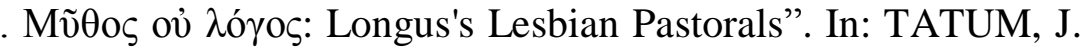
. "Chariton", In: SCHMELING, G., 1996, p.308-335.

. "Theme, structure and narrative in Chariton". In: SWAIN, S., 1999, p. 163-188 (original de 1982).

. The form of Greek Romances, Princeton, Princeton University

Press, 1991.

."The Ancient Novel at the Time of Perry", In: BYRNE, S., CUEVA, E., ALVARES, J. (eds.). Authors, Authority, and Interpreters in the Ancient Novel, Groningen: Barkhuis , Groningen University Library, 2006, p. 227-238.

REICHEL, M. "Xenophon's Cyropaedia and the Hellenistic Novel”, In: HOFMANN, H. (ed.). Groningen Colloquia on the Novel, vol.VI, 1995, p.1-20.

REITZENSTEIN, R. Hellenistische Wundererzählunge, Leipzig, Teubner, 1906.

REPATH, I. “Achilles Tatius' "Leucippe and Cleitophon': What Happened Next?”, The Classical Quarterly, vol. 55, n. 1, 2005, p. 250-265. 
REYNOLDS, J. “The First Known Aphrodisian to Hold a Procuratorship", In: SCHERRER, P., TAEUBER, H., THÜR, H. (eds.), Steine und Wege: Festschrift für Dieter Knibbe zum 65. Geburtstag, Vienna, 1999, p. 327-34.

RIESS, W. "Between Fiction and Reality: Robbers in Apuleius' Golden Ass", Ancient Narrative 1, 2000-2001, p. 260-282.

Apuleius und die Räuber: Ein Beitrag zur historischen Kriminalitätsforschung, Stuttgart: Franz Steiner-Verlag, 2001.

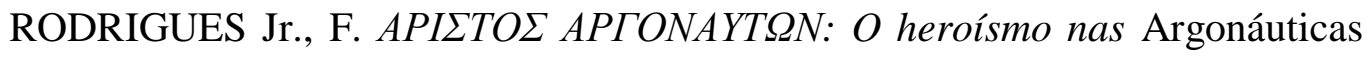
de Apolônio de Rodes. Tese de doutorado, São Paulo: Universidade de São Paulo, 2010.

ROHDE, E. Der grieschisch Roman und seine Vorlaufer, Charleston: Bibliolife, 2009 (original de 1876).

ROMM, J. "Belief and Other Worlds: Ktesias and the Founding of the 'Indian Wonders"'. In: SLUSSER, G., RABKIN, E. (eds.). Mindscapes: The Geographies of Imagined Worlds. Carbondale: Southern Illinois University, 1989, p.121-135.

The Edges of the Earth in Ancient Thought: Geography, Exploration, and Fiction, Princeton: Princeton University Press, 1994.

ROISMAN, J. The Rhetoric of Manhood, Berkeley: University of California Press, 2005.

ROSEN, I., SLUITER, R. Andreia: Studies in Manliness and Courage in Classical Antiquity, Leiden: Brill, 2003.

ROUGEMONT, G. "Delphes chez Héliodore”, In: BASLEZ, M., HOFFMAN, P., TRÉDÉ, M. (eds), 1992, p.93-100.

ROWE, C. "O tema da raiva na Retórica e na Ética de Aristóteles". Revista Archai, n.9, 2012, p.11-16.

RUIZ-MONTERO, C. "Caritón de Afrodisias y el mundo real", In: LIVIABELlA FURIANI, P., SCARCELlA, A. Piccolo Mondo Antico, Napoli: Edizioni Scientifiche Italiane, 1989, p.107-149. 
. "The Rise of the Greek Novel". In: SCHMELING, G.

(ed.), 1996, p. 29-86.

RUTHERFORD, I. "The Genealogy of the Boukoloi: How Greek Literature Appropriated an Egyptian Narrative-Motif”, The Journal of Hellenic Studies, Vol. 120, 2000, pp. 106-121.

SALMON, P. “Chariton d'Aphrodisias et la révolte e'gyptienne de 360 avant J.C.”, Chronique d'Egypte 36, 1961, p. 365-76.

SANDY, G. Heliodorus, Boston: Twayne, 1982.

. "The Heritage of the Ancient Greek Novel in France and Britain", In: SCHMELING, G. (ed.), 1996, p.735-773.

SCARCELLA, A.M. "La poléomologie des romans". In: BASLEZ, M., HOFFMAN, P., TRÉDÉ, M. (eds), 1992, p.63-74.

SCHMELING, G. Chariton, New York: Twayne, 1974.

The Novel in the Ancient World. Leiden: Brill, 1996.

SCHWARTZ, S. "Rome in the Greek Novel? Images and Ideas of Empire in Chariton's Persia”, Arethusa, vol. 36, n. 3, 2003, p. 375-394. $399-431$.

SCIPPACERCOLA, N. "La violenza nel romanzo greco", Lexis 28, 2010, p.

SCOBIE, R. "Storytellers, Storytelling and the Novel in Graeco-Roman Antiquity", Rheinisches Museum, n. 122, 1979, p. 229-59.

SCOURFIELD, D. "Anger and Gender in Chariton's Chaereas and Callirhoe". In: BRAUND, S., MOST, G., 2003, p.163-184.

SEBASTI, M.-A. "Une île romanesque: Arados", In: POUDERON, B., CRISMANI, D. (eds.), Lieux, décors et paysages de l'ancien roman des origines à Byzance: Actes du 2e Colloque de Tours, Paris, 2005, p. 87-99.

SELDEN, D. “Genre of Genre”, In: TATUM, J. (ed.), 1994a, p.39-63.

SMITH, S. Greek Identity and the Athenian Past in Chariton. The Romance of Empire. Ancient Narrative Supplementum 9, Groningen: Barkhuis , Groningen University Library, 2007. 
SOUZA, P. Piracy in the Graeco-Roman World, Cambridge: Cambridge University Press, 2002.

STADTER, P. "Fictional Narrative in the Cyropaideia", American Journal of Philology 112, 1991, p. 461-91.

STEPHENS, S., WINKLER, J. (eds.). Ancient Greek Novels: The Fragments. Princeton: Princeton University Press, 1993.

STEPHENS, S. “Who read ancient novels?”, In: TATUM, J. (ed.), 1994a, p.40518.

STROHMAIER, G. "Übersehenes zur Biographie Lukians”, Philologus 120, 1976, p.117-22.

STADTER, P. "Fictional Narrative in the Cyropaedeia", American Journal of Philology, 112, 1991, p. 461-491.

SWAIN, S. (ed.), Oxford Readings in the Greek Novel, Oxford, Oxford University Press, 1999.

TATUM, J. Xenophon's Imperial Fiction. Princeton: Princeton University Press, 1989.

TATUM, J. (ed.), The Search for the Ancient Novel, Baltimore and London: The Johns Hopkins University Press, 1994a.

. "The Education of Cyrus". In: MORGAN, J., STONEMAN, R. (eds.), 1994b, p.15-28.

TILG, S. Chariton of Aphrodisias and the Invention of the Greek Love Novel. New York: Oxford University Press, 2010.

TRZASKOMA, S. A Novelist Writing 'History': Longus' Thucydides Again”. Greek, Roman and Byzantine Studies 45, 2005, p.75-90. Novels”. Classical Philology, vol.106, n.1, 2011, p.61-65. 
"Why Miletus? Chariton's Choice of Setting and Xenophon's Anabasis", Mnemosyne 65.2, 2012, p. 300-307.

TUCÍDIDES. História da Guerra do Peloponeso - Livro I. Trad. A. L. Almeida Prado, São Paulo: Martins Fontes, 1999.

TURNER, P. “Daphnis and Chloe: an interpretation”. Greece \& Rome 7, 1960, p.117-23.

VAN NIJF, O. "Athletics, Andreia and the Askêsis-Culture in the Roman East", In: ROSEN, R., SLUITER, I., 2003, p.263-285.

VAN WEES, H. Status Warriors: War, Violence and Society in Homer and History, Amsterdam: J.C. Gieben, 1992.

Classical Press of Wales, 2009.

(org.) War and Violence in Ancient Greece, Swansea:

WALDEN, J.W. "Stage-terms in Heliodorus's Aethiopica", Harvard Studies in Classical Philology 5, 1894, p. 1-43.

WATANABE, A. "The Masculinity of Hipothoos", Ancient Narrative, vol.3, 2003, p. 1-42.

WATT, I. The Rise of the Novel, Berkeley/Los Angeles, University of California, 1957.

WEBB, R. Ekphrasis, Imagination and Persuasion in Ancient Rhetorical Theory and Practice, Farnham/Burlington: Ashgate, 2009.

WEINREICH, O. “Nachwort,”, In: REYMER, R., Aithiopika, Zurich, 1950.

WESSELING, B. "The Audience of the Ancient Novels", Groningen Colloquia on the Novel, 1, 1988, p.67-79.

WHITMARSH, T. "Heliodorus and the genealogy of Hellenism", In: HUNTER, R., 1998, p.93-124. ."The writes of passage: cultural initiation in Heliodorus' Aethiopica", In: MILES, R., Constructing identities in late antiquity, London: Routledge, 1999.

."The Greek Novel: titles and genre", American Journal of Philology, n.126, 2005, p. 587-611. 
. "Heliodorus smiles". In: HARRISON, S., PASCHALIS, M.

FRANGOULIDIS, S., 2005b, p.87-105.

(ed.). Cambridge Companion to the Greek and Roman Novel,

Cambridge: CUP, 2008.

Narrative and Identity in the Ancient Greek Novel:

Returning Romance, Cambridge: Cambridge University Press, 2012.

WIERSMA, S. "The ancient Greek novel and its heroines: a female paradox", Mnemosyne 43, 1990, p.109-23.

WINKLER, J. "The Mendacity of Kalasiris and the Narrative Strategy of Heliodoros' Aithiopika", In: SWAIN, S., 1999, p.286-349.

Auctor, Actor: A Narratologial Reading of Apuleius' The Golden Ass, Berkeley, University of California Press, 1985.

. "Lollianos and the Desperadoes", Journal of Hellenic Studies,

vol.100, 1980, p.155-181.

. "The Education of Chloe: Hidden Injuries of Sex". The

Constraints of Desire, New York/London: Routledge, 1990, p.101-126.

.’The Invention of Romance", In: TATUM, J. (ed.), 1994a, p.23-

38.

WINKLER, M. "The Cinematic Nature of the Opening Scene of Heliodoros' Aithiopika”, Ancient Narrative 1, 2000-2001, p.161-183.

WORONOFF, M. "Rapports de pouvoir entre les personnages dans les Éthiopiques", In: POUDERON, B., 2001, p.193-206.

ZEITLIN, F. "The poetics of eros: nature, art and imitation in Longus' Daphnis and Chloe". In: HALPERIN, D., WINKLER, J., ZEITLIN, F. (eds.), Before Sexuality, Princeton: Princeton University Press, 1990, p.417-64.

and Imitation”. In: TATUM, J. (ed.), 1994, p.148-170.

"Gardens of Desire in Longus's Daphnis and Chloe: Nature, Art

ZIMMERMANN, B. "The historical novel in the Greek world: Xenophon's Cyropaedia”. In: KARLA, G., 2009, p.95-103. 
